GODIVA ACCIOLY

\title{
TRANSPOSIÇÃO DE ÉPOCA E PERSONAGEM REAL DE TELEVISÃO
}

\author{
Universidade de São Paulo \\ Escola de Comunicações e Artes \\ Departamento de Artes Cênicas \\ ORIENTADORA: PROFA. DRA. RENATA PALLOTTINI
}

São Paulo 


\section{GODIVA ACCIOLY}

\section{TRANSPOSIÇÃO DE ÉPOCA \\ E PERSONAGEM REAL DE TELEVISÃO}

Tese apresentada ao Programa de Pós-Graduação em Artes, Área de concentração Artes Cênicas, Linha de Pesquisa Teoria e História do Teatro - Literatura Dramática, da Escola de Comunicações e Artes da Universidade de São Paulo, como exigência parcial para obtenção do título de Doutor em Artes, sob a orientação da Profa. Dra. Renata Pallottini.

São Paulo 
A tese de doutorado Transposição de época e Personagem Real de Televisão, realizada por Godiva Accioly, doutoranda do Programa de Pós Graduação em Artes, da Escola de comunicações e Artes da Universidade de São Paulo, foi no dia de de 2007,

pela Banca composta por:

$\operatorname{Prof(a).~Dr(a).~}$

$\operatorname{Prof}(a) . \operatorname{Dr}(a)$

$\operatorname{Prof}(\mathrm{a})$. Dr(a).

$\operatorname{Prof(a).~Dr(a).~}$

$\operatorname{Prof}(a) . \operatorname{Dr}(a)$. 
À minha família, com afeto. 


\section{AGRADECIMENTOS}

Todo conhecimento começa com o sentimento. Leonardo da Vinci

A todos que, ao meu lado, acompanharam a construção da personagem Dona Beija, orientando-me, Profa. Dra. Renata Pallottini, encaminhando-me, corrigindo-me e oferecendo-me além do conhecimento, o afeto e o sentimento necessários em tão prolongado empreendimento. Ao final, tenho a certeza de que sem o apoio intelectual e afetivo recebido, eu e Dona Beja não teríamos chegado ao porto seguro ora conquistado e ao qual aportamos mais fortes e realizadas do que quando partirmos em busca dos registros de tão fascinante história. 


\section{RESUMO}

Este estudo trata da vida de Anna Jacintha de São José (Dona Beja), em seu contexto histórico e na transposição dela feita para a televisão, a telenovela Dona Beija. Acompanhando-a em suas várias histórias, voltamo-nos, primeiramente, à análise histórico-social realizada nas fontes encontradas e depois ao seu exame e contraposição sistemática, o que se deu em terreno da memorialística histórica. Tal movimento nos conduziu para a interpretação da construção dessa personagem, por meio da tradução em diferentes contextos históricoculturais, tradução essa que culminou na transposição de sua história para a televisão. No campo específico da teledramaturgia, fizemos a análise da linguagem, da estrutura e da dramaturgia da telenovela Dona Beija, vista como produto da indústria e da tradução culturais. Tal análise constatou, enfim, a permanência do seu retrato feito brevemente pela teledramaturgia, em detrimento daquele que já há dois séculos vem sendo delineado na atuação da memória e da história.

Palavras-chave: teledramaturgia; história; cultura; memória; personagem Dona Beija. 


\begin{abstract}
This study deals with the life of Anna Jacinta of São José (Mrs. Beja), in its historic context and in the transposition made for television, the novel-television Dona Beija. Following her in its several histories, we turn ourselves, first of all, to social historical analysis carried through the known sources and later on its examination and systematic contraposition, which took a place in the historical memoralistic. Such movement lead us for the interpretation of construction of her character, through the translation of different historical-cultural contexts; translation that culminated in the transposition of her history to the television. In the specific field of dramaturgicnovel, we made the analysis of the language, the structure and the dramaturgic of Dona Beija's telenovel, seen as a product of industry and the cultural translation. Such analysis, evidenced, at last, the permanence of her picture, that was made briefly for the dramaturgicnovel in detriment of those have been done delineated for two centuries in the performance of her memory and history.
\end{abstract}

Key words: dramaturgicnovel; history; culture; memory; Dona Beija character. 


\section{SUMÁRIO}

\section{CAPÍTULO I}

Anna Jacintha de São José (Dona Beja): uma biografia possível

\section{CAPÍTULO II}

A tradução cultural de Beja: personagem e memória

Anna Jacintha segundo Totinha

Beja e o Ouvidor segundo totinha

Beja e São Domingos de Araxá segundo Totinha

Beja e a bagagem segundo Totinha

\section{CAPÍTULO III}

A construção e a transfiguração da personagem:

Dona Beja na pintura, no teatro, no romance e no carnaval

Pintura

Teatro

Romance

Carnaval

\section{CAPÍTULO IV}

Dona Beija: personagem real de televisão

Breves informações sobre a telenovela brasileira

Por fim, a sós com a novela Dona Beija

Anos de formação - (cenas-situação: 01 a 53)

Anos de ouro (cenas-situação: 54 a 178)

\section{CONCLUSÃO}


(...) Que eu vivo, padeço e morro só pelas três mulheres do sabonete Araxá! São amigas, são irmãs, são amantes as três mulheres do sabonete Araxá? São prostitutas, são declamadoras, são acrobatas?

São as três Marias?

A mais nua é doirada borboleta...

Manoel Bandeira 
Ao terminar o trabalho de mestrado e confirmadas as possibilidades de transposição de um drama musical $O$ Anel dos Nibelungos de Richard Wagner, para o cinema, na película muda, Os Nibelungos - A Morte de Siegfried (parte 1) de Fritz Lang, pude retomar, de forma incipiente, lembranças que foram sendo acumuladas durante o período de estudo e que se ligavam a outras, anteriores e revistas com curiosidade, quando me dispus a iniciar um novo projeto.

Dois insinuantes tópicos se destacaram, colocando-se como chave para minhas indagações. O primeiro deles surge no âmbito da história da cultura brasileira e trata de uma personagem real, perpetuada pela sua singularidade e posição histórica no contexto do mito feminino, que viveu nas Minas Gerais do século XIX, período em que se deu o processo de ocupação e desenvolvimento do Triângulo Mineiro, do qual participou intervindo política e culturalmente. Trata-se de Anna Jacintha de São José, a Dona Beja ${ }^{1}$.

O segundo tópico surge no momento em que, já envolvida pela tarefa de acompanhar o percurso da vida de Beja, colocou-se para mim a necessidade de pensar essa personagem em suas origens, sua personalidade e seu contexto. Uma pesquisa em que se percebem diferentes áreas da história que se cruzam, sugerindo seus temas e suas respectivas problemáticas. Posso acrescentar que, por ter como tônica a interpretação de uma vida, representa uma investigação que me coloca frente a infinitos significados e do problema das diferentes versões, que acompanham a construção do sentido atribuído à personagem.

Na tentativa de situar-me, querendo tudo e muito mais, recorri aos arquivos familiares aí encontrando um inestimável documento; a gravação da telenovela Dona Beija, realizada pela TV Manchete em 1986, com texto de Wilson Aguiar Filho e direção de Herval Rossano. Pus-me a vê-la e aí estava o segundo tópico, ou a possibilidade de investigar a idéia de transposição, em se tratando de Dona Beija.

Minha aproximação com o estudo da personagem aconteceu a partir das lembranças do que penso sempre ter ouvido falar (sou mineira e mais especificamente do Triângulo Mineiro), pelos descendentes de Beja ou pela maioria das pessoas, mineiras com convicção e admiração por esse símbolo local, ou de outras paragens, para confirmar a veracidade do já ter ouvido dizer. Lembranças guardadas cuidadosamente na memória, e agora complementadas

\footnotetext{
${ }^{1}$ Foram utilizadas diversas grafias para o nome da personagem (Beja, Bêja, Beija), visando distingui-la em suas muitas caracterizações.
} 
pela leitura da literatura disponível sobre o tema e seu contexto histórico-cultural, vieram corroborar minha intenção de ter Beja como protagonista nessa história-pesquisa.

Conheço o grande sucesso obtido pela TV Manchete ao exibir a telenovela Dona Beija, o que me leva a pensar na comunicação, a qual se presume advinda da qualidade do produto apresentado ao público, e a qual, por se tratar de uma transposição de época (o que reduz as possibilidades de alterações substanciais nas características básicas da personagem), deveu-se ao modelo-personagem vista na transposição televisiva.

Apresentam-se, pois, duas áreas interligadas: a do percurso de uma vida, a de Beja, e a da Teledramaturgia (campo onde se colocam as muitas indagações), dando origem à problemática fundamental desta pesquisa de doutorado.

$$
* * *
$$

Assim, o objeto deste doutorado, intitulado Transposição de Época e Personagem Real de Televisão, é a vida de Anna Jacintha de São José, Dona Beja, vista em seu contexto histórico e na transposição para a produção televisiva.

O enfoque dado a uma história de vida no estudo da transposição dela feita para o gênero telenovela, uma manifestação artística com sua linguagem própria e especificidades características ao seu saber fazer, amplia a análise proposta: a de colocar em foco uma figura que, apesar de mítica, é uma personagem comum. Pensá-la em suas origens, sua personalidade e seu contexto, permite caracterizar determinados trajetos da televisão brasileira moderna em seu tratamento dos dramas de família e de época.

A relevância fica por conta do que representa o caráter biográfico que reveste a pesquisa sobre a personagem, Beja, e que de acordo com o que nos diz Georges Duby (apud Pacheco, 2001), ao produzir um balanço sobre a pesquisa histórica na França, em 1988, assim se colocou:

Eu poderia, por exemplo, deplorar que a biografia - para dizer a verdade, dentre os gêneros históricos, um dos mais difíceis - tenha sido, nesses últimos trinta anos, tão esquecida pelos historiadores profissionais infelizmente, já que o grande homem, ou o homem médio, que o acaso faz com tenha falado muito ou se tenha falado muito dele, é, tanto quanto o acontecimento, revelador, por todas as declarações, as descrições, as ilustrações de que ele é motivo, pelas ondas que seus gestos ou suas palavras põem em movimento ao seu redor. (p. 4) 
E se assim pensamos, pode-se acrescentar o relevante papel da memória que, ao permitir a atualização da história-personagem, resgata a possibilidade não só da análise histórico-social como a sua tradução para a produção televisiva. Interessa-nos o como e o porquê de a televisão, localizada a necessidade de rememorar, eleger uma história de época e seu respectivo protagonista, como produto a ser veiculado e consumido pela audiência, conforme as exigências de mercado no momento de sua produção.

Falamos do caráter biográfico que envolve o estudo da personagem real e sua importância, da memória e sua permanência nesse processo de transposição e, por fim, o mergulho nas características de construção da telenovela, ou seja, questões que vão da natureza da ficção televisiva à estrutura da telenovela, compreendendo, nesse sentido, os principais aspectos da criação e recriação televisiva como fenômeno de comunicação dramática e valor estético.

Ao final, resta-nos reforçar a relevância deste estudo que traz, como uma de suas preocupações centrais, um programa - a telenovela - que atrai para si os olhares atentos e fascinados de pelo menos metade do público televisivo brasileiro - e da América Latina, segundo nos conta Renata Pallottini, em seu livro Dramaturgia de Televisão.

$* * *$

Acompanhando nossos propósitos, num primeiro momento, teremos a atenção voltada para uma história de vida, a de Beja, o que nos leva a uma questão central: escrever sobre Beja e o que a sua história pode revelar além do que já nos foi dito, pelos seus biógrafos, pela história oral, pelos inúmeros descaminhos da fantasia traduzidos em lendas que a tradição incorporou às verdades legitimadas pela história.

Nesse percurso, torna-se necessária uma aproximação com o estudo teórico da personagem: uma mulher incomum por suas experiências de vida e atuação no cenário político e cultural de seu tempo, o século XIX, que se coloca como lembrança, atualizada em pintura, livros, espetáculos teatral e televisivo e alegoria carnavalesca. Como nos diz Agripa Vasconcelos, um de seus biógrafos: "Eterna, porque D. Bêja vence as eras, pela coragem de suas atitudes indomáveis e pela graça quase divina de sua beleza" (Vasconcelos, 1985, p. 8). 
O autor será um de nossos referenciais não apenas nesse particular, a vida de Beja, acompanhado por Thomas Leonardos, autor de Dona Beija, A Feiticeira do Araxá, mas também na relação indivíduo-contexto, com suas obras sobre a história dos ciclos nas Gerais, entre outros autores que a Beja se dedicaram com variadas intenções, desde as meramente especulativas, até as apoiadas em abordagens mais consistentes, feitas sob o referencial da história cultural como Rosa Maria Spinosa de Montandon e Emmy Rudolph de quem guardamos o diário e preciosas lembranças de tempos que excederam as margens do Rio Bagagem.

Ecléa Bosi, Walter Benjamin, Georges Duby, Jaques Le Goff, Regina Abreu, Alain de Botton, Pierre Nora, Sérgio Miceli, Susan Griffin, Michael Baxandall, E. H. Gombrich, Leon Battista Alberti, foram nossos interlocutores na difícil tarefa de "captar o passado", tornando possível a análise histórico-social e a transposição de nossa personagem para a teledramaturgia. Ao lado desses autores consultados fomos cuidados por outros que, procurados, acudiram às nossas necessidades teóricas, deixando sua breve passagem registrada em nosso texto e em nossa memória.

A teledramaturgia nos coloca frente à necessidade de pensarmos nas imagens da televisão e na sua linguagem específica. A TV, ao contar uma história, está mostrando como ela foi construída em imagens e que sentido tem. Não se trata mais daquele sentido que, ao pesquisar a história de uma vida, nos perguntamos sobre ele, nem tampouco o que nós atribuímos à personagem. Trata-se sim do significado a ela dado pelo processo de filmagem, de criação, dos recursos técnico-estéticos utilizados na produção realizada em dado momento da história, como produto da indústria cultural.

Como ficou a personagem real em sua tradução para a personagem real de televisão?

Nesse fazer televisivo as permanências da memória do teatro e do cinema se evidenciam na utilização de suas experiências aplicadas à dramaturgia da televisão, terreno no qual nos situamos, além de outras fontes de origem da telenovela apontadas, em variados graus de relevância, nos trabalhos que tratam do assunto. Entre esses muitos antecedentes focamos nossas observações de forma mais objetiva no romance, no romance em folhetim e no melodrama teatral. Não nos furtaremos em dirigir nossas reflexões para essas artes e esses gêneros, suas análises e teorias, que compõem também, o universo da teleficção, acompanhados pela leitura de Renata Pallottini, Anatol Rosenfeld, Adolphe Appia, Ismail 
Xavier, Milton José de Almeida, Antônio Cândido, Merlise Meyer, Ivete Huppes e outros que a nós se juntaram no desenrolar da pesquisa.

$$
* * *
$$

Vamos, portanto, passar por exame obra televisiva, a telenovela Dona Beija, que fez a adaptação de textos histórico-biográficos sobre ela, tendo em vista a avaliação do diálogo entre a história textual e a história visual, com a caracterização de diferenças de estilo e propósito, conforme o momento de suas respectivas produções e a tradução cultural realizada.

Pretendemos acompanhar o percurso da vida de Beja, em suas origens, sua personalidade e seu contexto, partindo das fontes encontradas, sua análise e contraposição sistemática. O exame proposto coloca em foco a tradução cultural do papel desempenhado por uma mulher, num momento histórico marcado por transições políticas, econômicas, culturais e busca refletir sobre as relações sociais estabelecidas no interior de uma sociedade, a das Gerais, e outros temas como códigos e normas morais, padrões de educação e de convivência no século XIX.

Considerando a telenovela Dona Beija, analisa-se a transposição realizada para a produção televisiva, pela via da tradução cultural. A presença paradigmática da personagem histórica, Beja, reconstruída num outro momento estético cultural, o da televisão, reveste-se dos significados próprios da especificidade da linguagem televisiva em seu tratamento dos dramas de família e de época.

Tudo isso ainda leva a investigar, a partir da transposição realizada para a televisão, a natureza da ficção televisiva, dirigindo-nos para a análise da linguagem, da estrutura, da dramaturgia da teleficção, especificamente a telenovela, como produto da indústria e da tradução culturais. 
Constituem elementos teóricos básicos as noções de uma história de vida e de sua transposição realizada para a teledramaturgia, a primeira pertencente à análise histórico-social e, a segunda, à natureza da ficção televisiva e da estrutura da telenovela.

No desenvolvimento da tese de doutorado, o método de investigação conjugou a pesquisa bibliográfica e as fontes advindas dos documentos pessoais e dos depoimentos colhidos entre os que registraram em sua memória, episódios que nos contam de Beja e dos usos e costumes do interior mineiro no século XIX. O estabelecimento dos fatos se deu mediante a contraposição das diversas versões analisadas.

Na seqüência, fazemos a confluência da trajetória de vida de Dona Beja, com a imagem real de Dona Beija em sua caracterização televisiva, reproduzida com os recursos técnico-estéticos próprios da teledramaturgia num tempo que imita o ritmo da vida e envolve o tempo presente do telespectador, presentificando Beija com realismo.

Para tratar dessa temática foi acrescentado ao referencial teórico anteriormente abordado, a análise dos aspectos da produção da telenovela, da criação ao resultado final apresentado ao público, o que permitirá a contraposição dos dois espetáculos: o de uma história de vida e o da telenovela.

Neste espaço, o da televisão, por nós considerado o mais difícil de ser explorado, fomos acompanhados por Renata Pallottini, Maria Cristina Castilho Costa, Esther Hamburger, Arlindo Machado, Ciro Marcondes Filho, Artur da Távola, Ismael Fernandes, Mauro Alencar, entre muitos outros autores, os quais atenderam nossas solicitações. Podemos assegurar que não foram poucas. Mas, de qualquer forma, fossem solicitações de ordem teórica, ou informativa, ou mesmo quando buscávamos um possível reforço para as pequenas ousadias que, vez por outra, nos concedemos, foram resolvidas mediante a intervenção segura desses nossos interlocutores, ora imediata, ora mediada pela polêmica intelectual causada por diferenças de ponto de vista.

Não podemos deixar de mencionar nosso, de início, relutante acesso aos arquivos virtuais, ao estudarmos a telenovela, no momento em que ficou patente a impossibilidade de localização de documentos ou informações sobre Dona Beija. Embora esse aspecto vá ser tratado no decorrer do capítulo IV deste trabalho, é bom antecipar que a dificuldade em localizar informações ou documentos relativos à telenovela, bem como a indisponibilidade de pessoas, que pelo fato de terem participado de seu processo criativo e de sua produção, poderiam contribuir conosco, com seus depoimentos e sua experiência, significaram para nós 
momentos de ansiedade e angústia no andamento na pesquisa. Aos poucos, porém, fomos aprendendo a trabalhar com o que dispúnhamos ou, melhor dizendo, com o possível. Afinal, trabalhar em situações adversas faz parte do ofício do pesquisador, que bem pode aproveitar tal surpresa para buscar um caminho pessoal. Como pesquisadora, portanto, resta-nos o consolo de, ao ter vencido a barreira que se interpôs entre nossas intenções e a realidade possível, imaginarmos termos sido mais criativos, o que não quer dizer eficientes.

Arlindo Machado (2000) ajudou-nos em nossa resignação motivadora, já que foi a partir da constatação da falta de documentos que buscamos outras formas de abordagem e de reflexão sobre Dona Beija, ao assim se colocar sobre o problema: "No Brasil, não existem instituições de arquivamento sistemático da produção nacional, mas se o interessado fizer parte da estirpe dos que jamais desistem, não custa bater à porta das próprias redes e produtoras" (p. 238).

Verifiquemos os obscuros destinos tomados pela mercadoria Dona Beija, produzida pela Rede Manchete:

Quando saiu do ar, em 1998, a concessão da Rede Manchete passou para a TV Ômega (Rede TV!). Já imóveis e equipamentos foram comprados pela Hesed Participações, de Fábio Saboya. Com eles, o acervo. Como a Bloch Editoras faliu, o prédio do grupo foi lacrado pela Justiça. (...) Teoricamente, as fitas de Xica da Silva e Dona Beija fariam parte desse acervo, mas o SBT, por meio de sua assessoria de imprensa, não confirmou, até o fechamento desta edição, a quem pagou para obter esse material. (Stivanin, 2005)

Em 4 de fevereiro de 2005, no Diário de São Paulo, Kogut informou:

O remake de 'Dona Beija', de Wilson Aguiar Filho, poderá inaugurar a segunda faixa de novelas na Record. A direção da emissora está negociando os direitos sobre o folhetim com a família do autor; que morreu precocemente aos 38 anos, em 1990.

Ainda em 2005, em 24 de Abril, Stivanin escreveu: "A intenção do SBT é substituir $X_{i c a^{2}}$ por Dona Beija, também da Manchete. Se isso será consumado, só Sílvio Santos sabe”.

A verdade é que nem uma nem outra emissora exibiu Dona Beija em 2005 e os recortes feitos na mídia especializada em televisão, repetem o desencontro que nos surpreendeu em nossa mal sucedida busca.

\footnotetext{
${ }^{2}$ Essa grafia foi apenas utilizada na telenovela. Agripa Vasconcelos utilizou a seguinte grafia: Chica.
} 
Voltemos aos arquivos virtuais os quais nos trouxeram informações necessárias a variados aspectos de Dona Beija, e também à gravação, em vídeo, da telenovela, encontrada, como vimos, nos arquivos familiares, imagens que estiveram sempre a mão, colocando-se como fonte imprescindível para a realização desta tese de doutorado.

Finalmente, ressaltamos que a adaptação da vida de Beja para o gênero telenovela, atingiu, por ocasião de sua exibição, um grande sucesso aqui no Brasil e no exterior. Tal fato legitima a nossa escolha e amplia as possibilidades de aprofundamento de estudo do fenômeno teleficcional.

$* * *$

Quanto a forma de apresentação do que resultou de nossa prolongada convivência com Beja, a personagem histórica, e Dona Beija a personagem real da televisão, pretendíamos algo que revelasse as rotas percorridas nesse estudo, nem sempre definidas ou calculadas, mas para nossa surpresa, ela assim se colocou, de forma prosaica e nada criativa:

A primeira parte e seus dois capítulos analisaram os componentes essenciais de Dona Beja, na condição de história de vida, baseada nos elementos da historiografia e da memória. Beja nela se inscreve em dois capítulos: o primeiro dedicado a uma apresentação próxima do que, em geral, dela se conhece e que denominamos, Anna Jacintha de São José: uma biografia possível; o segundo, Tradução Cultural de Beja: personagem e memória, volta-se para a Beja que, segundo Totinha (sua bisneta) permaneceu na memória familiar, ponto de partida para a atualização da personagem, o que se deu por meio de outras linguagens e em outros tempos.

A segunda parte, e seus outros dois capítulos voltam-se primordialmente para o estudo da transposição de época nas diversas atividades culturais que se servem de imagens, como a pintura, o romance, o teatro, o carnaval, a televisão e outras afins, concentrando-se sempre na figura de Beja como personagem em permanente construção.

Devem-se assinalar as diversidades no campo da transposição de época, dando destaque à produção televisiva e delimitando-a à época selecionada, quanto ao espaço e ao tempo. 
Nesse espaço encontramos no terceiro capítulo: A construção e transfiguração da personagem Dona Beja: na pintura, no teatro, no romance e no carnaval; e finalizando, no quarto capítulo: Dona Beija: personagem real de televisão.

$\mathrm{Na}$ conclusão procuramos mostrar, como razão mesma do estudo, as principais questões da transposição de época e da personagem real de televisão Dona Beija, como novela de sucesso e como componente do atual estágio da história da cultura brasileira.

Fixamos, pois, um retrato dentre outros do que vamos denominar de "gosto" televisivo, tão cultivado pela indústria da televisão, e por seus telespectadores, nas últimas décadas do século XX, no Brasil. 


\section{ANNA JACINTHA DE SÃO JOSÉ (DONA BEJA): uma biografia possível}

D. Beija não existiu, nada. É uma lenda que o Sebastião da Fonseca (historiador já falecido da cidade) contou para o Assis Chateaubriand, dono dos Diários Associados. O Chateaubriand estava doente, hospedado no Barreiro, e o Sebastião da Fonseca ficava descrevendo as aventuras, o corpo e a beleza de D. Beija. O Chateaubriand, adorando a história e ficando encantado por ela, comprou a casa que teria sido dela e doou-a para a Prefeitura fazer o Museu D. Beija. Além disso, passou a divulgar a história de D. Beija pelos jornais dele por todo o país.

Abreu Filho 
“Todos conhecem Beja e ninguém sabe que é Ana...", diz João, o avô, ao apresentá-la aos hóspedes da pensão onde se abrigaram, ao chegar ao Arraial de São Domingos de Araxá. $\mathrm{O}$ apelido dado por ele à neta ligava-se a atração da menina pelas flores, que não se contentava em vê-las sem cheirá-las, o que o fez compará-la ao pássaro, beija-flor. "Depois, passou a ser chamada somente de Beja" (Vasconcelos, 1985, p. 39).

Foi como Beja que permaneceu na história, mas nasceu Anna Jacintha de São José, no dia 2 de janeiro de 1800, na Fazenda de Formiga Grande, próxima à cidade de Formiga, no Oeste mineiro.

Beja não conheceu o pai. Seu registro de nascimento traz apenas o nome da mãe; pai desconhecido. Ele, provavelmente, um caixeiro viajante paulista, seduziu sua mãe, Maria Alves de São José, desaparecendo na poeira das estradas mineiras sem deixar rastros.

Os "cometas" como eram denominados esses comerciantes ambulantes que circulavam pelas terras mineiras, representavam a fonte mais freqüente para aquisição de inumerável quantidade de mercadorias, que iam de tecidos a gêneros alimentícios, além de trazerem em sua bagagem, as notícias de um mundo distante e inacessível aos seus compradores. Tudo isso, aliado à boa aparência e ao dom da palavra que, normalmente, os caracterizava, permitia-lhes fácil acesso aos lares visitados, nem sempre hospitaleiros em relação a estranhos, dada a rigidez com que as famílias estabeleciam suas relações sociais (Rosa, 1999).

A ordem reinante na casa do Major João Alves, pai de Maria, foi repentinamente alterada. Homem enérgico e honrado, proprietário de pequena fazenda com lavoura e criação, João criara a filha conforme os costumes da época, limitados pelos códigos morais de conduta vigentes, que destinavam às mulheres o papel de serem boas esposas, boas cristãs e boas mães.

Como poderia Maria, jovem tímida e recatada, confinada no ambiente doméstico, agir dessa forma? Nem mesmo sua mãe, D. Nhanhá, poderia explicar já que a moça fechou-se em seu desespero nunca revelando a ninguém nenhum dado sobre sua triste aventura, que mudou o rumo da vida dessa pacata família: D. Nhanhá, de saúde precária, não resistiu à angústia de ver a filha desonrada e à temida reação de João quando tomasse conhecimento da notícia, o que veio a se dar no dia do nascimento de Beja, falecendo em seguida. João, após a morte da mulher, mesmo tendo aceitado a neta, procurou se desvencilhar de sua propriedade, mudandose, algum tempo depois, com a filha e a neta, para o arraial de São Domingos de Araxá. Maria 
tornou-se cada vez mais inexpressiva em sua permanente humilhação até sua morte prematura.

Diante das conseqüências provocadas pelas circunstâncias do nascimento de Beja, pode-se olhar para trás e dizer que era o que acontecia naquela época, mas, para João, Nhanhá e Maria, deve ter sido tão imprevisível quanto determinante do processo de transformação pelo qual passaram e, de certa forma, não se recuperaram.

E Beja? Sua famosa beleza, em parte lendária, já que não restaram imagens, aparece em palavras de testemunhas afiançadas pela tradição oral, que a apresentam com um rosto harmonioso iluminado por grandes olhos verdes e emoldurado por cabelos castanho-dourados. A essa imagem idealizada, acrescenta-se a inteligência que a caracterizou, fazendo-a superar a pouca educação recebida em seu meio humilde e de poucas letras.

A menina viveu seus primeiros anos em meio aos conflitos provocados pelo drama doméstico, porém a atmosfera sombria que dominava o cotidiano familiar pouco interferiu em seu temperamento alegre e vivaz.

A partida da fazenda de Formiga rumo ao planalto araxano deu-se cinco anos após o nascimento de Beja. A família do Major João afastava-se para sempre de Formiga, para recomeçar a vida no distante Arraial de São Domingos de Araxá, no Triângulo, que a essa época deixara, há muito tempo, de ser mineiro.

A anexação das terras mineiras a Goiás, desbravadas pelas entradas e povoadas por faiscadores de ouro e garimpeiros, deveu-se a motivos de ordem fiscal, já que a taxação sobre a extração de pedras preciosas feita em território da Capitania de Minas era consideravelmente mais alta do que a realizada em solo goiano, o que motivou o movimento separatista que, ao final de longa disputa, terminou favorável à Capitania de Goiás.

Ao celebrar a primeira missa nos sertões do Araxá, e isso se deu em 4 de Agosto de 1788, o Padre Antonio Alves Machado declarou, ao final, a posse do Triângulo para a Vigairaria de Goiás (Leonardos, 1986).

Em terras goianas, a família de Beja passa a viver na fazenda de Sobrado, próxima ao Arraial de São Domingos de Araxá. João, com seus modestos recursos, arrendara a terra por dez anos e nela recomeçaria a vida ao lado da filha, da neta e do escravo Moisés, que acompanhara a família desde Formiga. 
Os negócios prosperaram graças às características do solo, da água e do clima temperado, que traziam para a lavoura e a criação resultados surpreendentes. E a vida transcorria nos moldes das muitas pequenas vilas que, nesse tempo, plantavam-se em meio às paragens distantes, recebendo dos centros mais civilizados apenas os ecos da história que aí se realizava.

Para os habitantes do Arraial de São Domingos de Araxá, não era diferente. A vila aparecera no caminho dos que buscavam riqueza fácil na cata do ouro e na extração de diamantes, o que fez da área central do Brasil um lugar cobiçado e rapidamente povoado. Os que nela se estabeleceram encontraram nas atividades rurais e no comércio a sua subsistência. Aos poucos, a população aumentava com os que vinham atraídos pelas propriedades das terras e da água locais, como fizera o Major João.

Beja visitava o Arraial de São Domingos de Araxá aos domingos, único dia em que o Largo da Matriz saía de sua calma habitual. A população alimentava o mesmo fervor místico praticado nos primeiros tempos do povoamento, assim como se conservavam o conjunto de princípios e leis instituídos pela Igreja. A afluência de fiéis para a missa de domingo era grande: os que ali moravam e os que vinham dos arredores.

Beja assistia à missa e, em seguida, reunia-se às demais crianças para as aulas de catecismo, realizadas na sacristia da igreja e que seriam, no seu caso, as únicas aulas que teria, já que não the foi dado aprender a ler e escrever, comum nessa época, quadro que se prolongou até o final do Império. "Na época da implantação do regime republicano, do total das mulheres, quase dois terços eram analfabetas, embora o mesmo acontecesse com a população em geral" (Almeida, 1998, p. 56).

A Lei Imperial de 15 de Outubro de 1827, que determinou a abertura de escolas de primeiras letras em todas as cidades, vilas e lugarejos, em todo o território nacional e que dava à mulher brasileira o direito legal à instrução pública, não beneficiou Beja. Por outro lado, a possibilidade de ser educada em casa, pelo próprio avô não aconteceu. Para ele, bastava o que a neta já sabia: o catecismo, que aprendera com o padre, bordar e fazer rendas tão bem quanto à mãe e a montar como um bom cavaleiro, o que devia a ele.

O confinamento doméstico em que vivia Beja, diferentemente do vivido pelas meninas que moravam na vila, possibilitava a ela experiências de liberdade que modificavam o processo de adaptação ao modelo feminino pretendido para a época. 
O fato de montar como um cavaleiro, uma transgressão para os limites definidos do que se espera de uma menina e a aprovação do avô, representada pelo chicote com cabo de prata com que a presenteou e que a acompanharia até o fim de sua vida, é um dos indícios dessa liberdade.

Nas circunstâncias apresentadas, que proporcionavam a Beja uma ampliação de limites dos comportamentos e padrões sociais e culturais estabelecidos, pode-se incluir a ausência de uma imagem de mulher que fosse convincente, ou melhor, que refletisse o modelo de papel feminino, presente nas outras famílias e que na sua apresentava-se desbotado na figura quase invisível de Maria.

O possível controle, a autoridade e a disciplina aos quais a menina, quase moça, estaria submetida e que no seu caso dependeria da mãe, cederam espaço para a manifestação de sua autonomia.

Seriam essas conquistas, resultantes das circunstâncias em que se deu o processo de formação/transformação de Beja, e que podem ser sintetizadas como um movimento de construção de uma personalidade independente, capaz de pensar por si mesma, que a faziam sobressair em seu meio.

Nas suas visitas domingueiras a São Domingos de Araxá, muitos eram os que a esperavam à saída da Matriz para admirá-la. Talvez mais do que a sua beleza, era a sua singularidade o que atraía esses olhares e provocava os elogios dirigidos ao avô pelos mais íntimos.

Beja tinha então, 13 anos. Para ela, as idas a São Domingos de Araxá significavam a oportunidade de ver Antônio (ou Manoel, não se sabe ao certo), jovem que conhecera nas aulas de catecismo. Filho de Antônio Sampaio, abastado fazendeiro das proximidades, apaixonara-se por ela e, aos dois, só se permitia verem-se à distância, não impedindo a atração mútua que, mais tarde, os uniu.

Nesse tempo, muita coisa mudou na vida de Beja. Maria, sua mãe, morreu repentinamente. Beja agora só contava com o avô, já bastante idoso e impossibilitado de tocar a rotina da fazenda. Mudaram-se para uma casa alugada em São Domingos de Araxá e, no ano seguinte ao da morte de sua filha, João resolveu desfazer-se da criação e entregar a fazenda para ficar mais próximo da neta.

Beja passou a participar dos acontecimentos locais, podendo usufruir da convivência com outras famílias que não a sua, o que desenvolveu a sociabilidade da jovem, tornando-a 
mais cativante. Os pedidos de casamento não tardaram a acontecer, porém, como era costume, durante o período de luto, a vida fazia uma pausa, para que a dor e a saudade se aquietassem.

Externamente, as transformações pelas quais passava a Colônia, então Vice-Reino, seguiam o seu curso, na esteira das grandes mudanças sociais que ocorriam na Europa e consequentemente nas colônias européias.

Com a chegada, em 1808, de Dom João, o príncipe regente, sua família e seu séquito à Colônia, inicia-se um período de alterações significativas na vida nacional. Entre elas, a transferência da capital para o Rio de Janeiro, trazendo mais para o sul o desenvolvimento econômico anteriormente voltado para as regiões norte e nordeste. Uma importância maior é dada a essas regiões que ficaram mais próximas da Corte, o que facilitou a comunicação e um maior conhecimento das suas possibilidades produtivas.

A Capitania de Minas Gerais, por sua produção aurífera, passa a ser uma das mais importantes da Colônia e um trânsito maior se estabelece entre os seus habitantes e os da capital.

Dá-se início a um processo de assimilação dos usos e costumes de vida burguesa e urbana, praticados na grande cidade e gradativamente implantados nas sociedades provincianas, provocando mudanças de hábitos da população, que passava a participar mais de perto da modernização da vida social e política do Brasil.

Em São Domingos de Araxá apareciam os primeiros sinais de desenvolvimento segundo os padrões europeus, o que era perceptível na urbanização, nas construções mais cuidadas, nas roupas e numa certa sofisticação até então ausente dos hábitos simples praticados por seus habitantes.

Beja também mudara. Fizera 15 anos e tornara-se uma jovem encantadora.

Foi durante as festas preparadas para receber o Ouvidor do Rei que sua situação de jovem comum, preparada para representar o papel que era esperado da mulher, o de esposa, mãe, dona de casa, seria definitivamente modificada.

Joaquim Inácio Silveira da Mota, homem de confiança do Príncipe Regente e amigo do Príncipe Pedro, chegara ao Brasil com a família real. Bem nascido e formado em direito pela Universidade de Coimbra, apresentava-se com a educação própria de um cavalheiro, possuidor de todos os requisitos necessários à convivência na Corte. Estavam entre as 
atribuições de seu cargo a inspeção e correição judicial, o ajuste e conferência das despesas da Justiça, além de transmitir ao rei o que ouvira no exercício de sua função.

A Ouvidoria tinha sede em Paracatu do Príncipe, na Capitania de Minas Gerais, também residência oficial do Ouvidor. Sua visita a São Domingos de Araxá representava uma honra para os seus dignatários e dava maior importância política para a região. Nenhum esforço foi poupado para receber o ilustre visitante. Tentava-se com os recursos locais e com os que, durante meses de preparativos, foram encomendados na capital, dar ao evento a atmosfera própria dos cerimoniais da Corte. Da casa do Juiz de Direito Preparador, Dr. José da Costa Pinto, onde se hospedou com sua comitiva, ao salão preparado para o baile que fecharia as inúmeras atividades oficiais a serem realizadas, tudo fora adequado de forma a atender às necessidades do Ouvidor.

Beja, como todas as moças, se preparara para o baile. Sua presença despertou a atenção de todos os presentes, como sempre acontecia em suas aparições públicas, incluindo nesse dia a do Ouvidor que, encantado com a beleza da jovem, dançou com ela a valsa de abertura, não escondendo aos demais, sua admiração.

A partir desse acontecimento, pouco se sabe dos motivos que levaram o Dr. Mota a planejar o rapto de Beja, o que se deu após a sua saída do arraial e que custou a vida de João Alves, ao tentar defender a neta.

As providências tomadas pelas autoridades de São Domingos de Araxá como a cartaofício redigida pelo Padre Aranha, pároco local, relatando o ocorrido e enviada ao CapitãoGeneral Governador de Goiás, e a indignação da população exigindo do Promotor que o duplo crime fosse punido, tendo este garantido que faria uma representação contra o Ouvidor, dirigida não só ao Governador e ao Tribunal da Relação do Paço, mas se necessário ao Regente D. João, não tiveram efeito.

Beja não retornou à sua casa e o Dr. Mota não foi julgado. Voltou no tempo devido à Corte e posteriormente a Portugal, onde faleceu com mais de 80 anos (Rosa, 1999).

O rapto e suas conseqüências podem ser considerados como fatores determinantes do destino de Beja. Não há como comprovar a validade dessa observação, mas as representações do passado derivadas das poucas fontes existentes, muitas delas transmitidas pela tradição oral, confirmam essa hipótese.

A virgindade feminina aparece nesse contexto, início do século XIX, como um requisito fundamental para se conseguir um casamento respeitável. Beja não correspondia 
mais ao modelo de esposa imposto pela sociedade e admitido pelo círculo social ao qual pertencia, e igualmente instituído na vida cotidiana do pequeno arraial de São Domingos de Araxá. Não poderia voltar para casa, mesmo porque perdera a única pessoa que lhe restava, seu avô.

Passado o impacto dos primeiros dias, a realidade se impôs: estava em Paracatu do Príncipe, no Palácio da Ouvidoria com o seu raptor, o mandante do crime que lhe tirou o avô, um homem maduro, 35 anos, e sedutor. De índole corajosa, Beja não deixou que o desespero a dominasse, embora, pelo que se tem notícia, tenha passado por um período de profunda melancolia, enfraquecida, recusando-se a sair de seus luxuosos aposentos.

Por outro lado, o Ouvidor, Dr. Mota, não media esforços para conquistá-la. Entre os muitos presentes, vestidos finos e jóias, deu-lhe uma escrava que sabia ler. Seu nome era Severina. Jovem como Beja, a escrava cativou-a ao tornar-se sua tradutora, revelando-lhe um mundo desconhecido, o da linguagem escrita. Talvez, pelas circunstâncias em que seus destinos se cruzaram, Severina passou a ser, mais do que uma escrava, uma companheira querida, que não abandonaria sua Sinhá, acompanhando-a até sua morte.

Em seguida, vieram Moisés e Flaviana, escravos de João Alves. O ouvidor mandara ordem para o Subdelegado de São Domingos de Araxá cumprir, além de dois cavalos para que pudessem fazer a viagem a Paracatu, onde permaneceram a serviço de Beja. Mais do que isso, davam a ela a ilusão da segurança que perdera ao ser arrancada de sua casa.

Beja foi, aos poucos, adaptando-se à sua nova vida: a de cortesã do Ouvidor.

Pode-se aqui usar o adjetivo cortesã, um conceito europeu, dadas as semelhanças encontradas entre a história de Beja e a de outras cortesãs que se tornaram míticas na história feminina. Possuidoras de beleza incomum, essas mulheres tinham outros atributos pessoais responsáveis por uma condição de vida muito diferente da prostituta comum. Usufruíam de fortuna, poder e de um estilo de vida peculiar, geralmente luxuoso e de certa forma respeitável, o que dava a elas autonomia econômica e social.

Para Susan Griffin (2003), o que realmente distingue a mulher sustentada e as cortesãs é o fato de que essas foram personagens, o que seria próximo do sentido que tem hoje as celebridades. E acrescenta: "só as corajosas e inteligentes seriam capazes de sobreviver à trajetória" (p. 21).

De origem humilde, analfabeta e sem nenhum traquejo social a não ser o adquirido no convívio com as famílias de São Domingos de Araxá, Beja teve de aprender as habilidades 
necessárias à representação do seu novo papel. Sua inteligência associada a um caráter firme, porém sensível, foram os seus guias no processo de transformação a que foi submetida.

Iniciava-se uma relação amorosa duradoura, diferente das que normalmente ocorriam em situações semelhantes, em que raptos ligados a paixões fulminantes, envolvendo pessoas de origens incompatíveis, acabavam com o abandono imediato da mocinha ultrajada.

Poderia até ter sido essa a intenção do Ouvidor, mas a repercussão do fato e suas conseqüências mais óbvias, como a abertura do inquérito autorizada pelo Governador de Goiás, e a impossibilidade de voltar à Corte até que tudo serenasse, fizeram com que o seu envolvimento com Beja perdesse o caráter momentâneo.

Acredita-se que além desses fatores de ordem prática e comprováveis, outro mais sutil tenha sido determinante e estaria relacionado com o encantamento provocado pela presença da jovem em sua vida, temporariamente solitária por imposição de suas funções, exercidas fora do alcance dos prazeres palacianos.

Paracatu do Príncipe, sede da Ouvidoria, era em muitos aspectos mais desenvolvida que as demais localidades da região.

Situada na Capitania de Goiás, a sucessiva descoberta de lavras de ouro permitiu um desenvolvimento contínuo ao lugarejo, Ribeira de Paracatu, que em 1798 foi elevado, por alvará, à Vila de Paracatu do Príncipe. Em 1815, contava com vinte e quatro mil habitantes, um número considerável para os padrões da época.

Como Comarca, possuía autonomia jurídica, tendo sob sua jurisdição além de São Domingos de Araxá, mais de uma dezena de vilas e arraiais. Com a criação da Comarca e pela extensão de suas atribuições, vieram bacharéis portugueses e funcionários importados da Corte, assim como, por ser Base do Quartel-Geral do Exército, juntaram-se à população local oficiais e soldados vindos de outras paragens.

Dos moradores locais, muitos foram os que se tornaram ricos com o ouro e, diferentemente da população de São Domingos de Araxá, formada por gente simples, de origem rural, cultivava-se em Paracatu um estilo de vida mais requintado e culturalmente mais próximo ao da Corte.

Beja foi integrada a essa realidade como a cortesã do Ouvidor. Acompanhava-o nos atos públicos e recebia as autoridades locais, no palácio da Ouvidoria. Para todos, ficara claro 
que grande era a sua influência nas decisões tomadas pelo Dr. Mota. O fato de ser ele um homem casado, não representou um motivo para que a sociedade local a rejeitasse.

A esse respeito, o historiador Eduardo Frieiro (1981) questiona: "Porque a Beija, conforme reza a tradição, viveu dois anos em estado de comborçaria com o seu sedutor. Era homem casado, mas o concubinato, naquele tempo, era mais freqüente - ou mais às claras? Esta última hipótese deve ser a certa” (p. 177).

Continuando, o autor se refere ao testemunho deixado pelo naturalista Saint-Hilaire em sua obra Viagem às nascentes do Rio São Francisco, sobre o "relaxamento geral dos costumes", observado no Oeste mineiro e em toda a Província de Minas concluindo: "Garantem-me, sem embargo, que há aqui muita gente casada; mas, pouco se respeita a fidelidade conjugal” (Saint-Hilaire apud Frieiro, 1981, p. 177).

O certo é que, seja em razão dos costumes da época ou da influência exercida pelo Dr. Mota, em função de seu alto cargo, Beja reinou em Paracatu com a desenvoltura necessária à sua condição de cortesã do Ouvidor.

Apropriou-se da educação que lhe foi oferecida pelo amante, transformando-se em uma dama, moldada segundo os costumes da corte. Aprendeu a se vestir, a ter a elegância devida aos protocolos palacianos, a exercitar sua capacidade intelectual no convívio com pessoas influentes, comportamentos que ampliaram sua autonomia, conquistada mediante o cancelamento de qualquer possibilidade de ser enquadrada no modelo feminino próprio do mundo social ao qual pertencia.

Foi nesse momento que Beja deixou o círculo da vida privada para fixar-se como figura política, âmbito geralmente negado à condição feminina em seu tempo. Nota-se nessa passagem uma mudança na imagem de vítima, imposta a Beja pelo seu drama pessoal, para a de heroína, imagem que prevalecerá no imaginário mineiro. A observação, que aqui se registra, não é baseada em fontes, já que os processos de decisão envolvem motivações e possibilidades, difíceis ou quase impossíveis de serem avaliadas por se darem "nos corações e nas mentes dos personagens, num cruzamento dos tempos passado, presente e futuro bastante imbricados" (Borges, 2001, p. 7).

O fato é que ao assumir o papel de cortesã, Beja o fez de modo a transformar o que poderia ser a sua ruína moral e social em fonte de poder e realização pessoal, quer no sentido da independência econômica, quer na determinação de pensar o futuro como mulher 
transgressora, o que exigiria habilidade pouco comum, a de ter consciência do momento presente no sentido de mover-se junto com a história.

E foi o que ela fez. Sabia do processo instaurado pelo Governador da Província de Goiás, inimigo confesso do Dr. Mota, para apurar sua culpabilidade no duplo crime, o de seu rapto e o do assassinato de seu avô. Após inquérito realizado em São Domingos de Araxá, não restava dúvidas quanto à participação do Ouvidor como mandante dos crimes. Ele estava, portanto, sujeito às sanções da justiça, no caso aplicada pelo governador goiano, já que São Domingos de Araxá, pertencendo à Província de Goiás, encontrava-se sob sua jurisdição.

Os registros históricos atestam que, desde a anexação das terras mineiras ao território goiano, os "mineiros" nunca aceitaram a espoliação sofrida, manifestando-se, periodicamente, sem sucesso, como no caso do abaixo-assinado enviado a Dom João VI, em 1814, no sentido de reincorporar a Minas as áreas perdidas. Caberia às circunstâncias provocadas pela paixão do Ouvidor por Beja e da sua atuação no desenrolar dos acontecimentos, a finalização do episódio que, pela sua importância sociopolítica, se encarregaria de inserir Beja, como heroína, na história local.

Beja interveio e conseguiu seu intento: o Sertão do Novo Sul, hoje Triângulo Mineiro, foi reintegrado à Província de Minas Gerais ${ }^{3}$. Terminava assim uma questão territorial iniciada no século XVIII que envolvera motivos político-econômicos, na qual a Província de Goiás saíra vencedora, aumentando os seus domínios com uma parcela considerável das terras antes mineiras.

Terminava também a possibilidade de punição do Ouvidor, pois São Domingos de Araxá, onde se deram os crimes, passava para a jurisdição da comarca de Paracatu, ficando o caso sujeito à sua Ouvidoria.

A história não deixou pistas da participação efetiva de Beja na decisão tomada pelo Ouvidor, a de convencer Dom João VI. Para tanto, deve ter o Dr. Mota usado de argumentos baseados nas vantagens políticas e fiscais que resultariam da reanexação das terras a Minas, encobrindo as razões pessoais que motivavam o seu pedido. A decisão real veio expressa na Carta Régia de 4 de abril de 1816, redesenhando as fronteiras mineiras acrescidas dos domínios temporariamente perdidos.

\footnotetext{
${ }^{3}$ O Triângulo Mineiro compreende 94.500 quilômetros quadrados, área superior a de alguns Estados, como os de Santa Catarina ou Rio Grande do Norte.
} 
À representação cartográfica do território mineiro, foi acrescentada uma saliência, de certa forma mítica para os que são do Triângulo Mineiro, por traduzir o que chamam do “nariz" de Minas.

$\mathrm{Na}$ ausência de provas documentais ou de testemunhas capazes de comprovar ou não a relevância da participação de Beja no desfecho da questão territorial mineira, episódio que deu início ao processo de legitimação de sua figura como heroína, só se pode imaginar. Buscam-se preencher as lacunas existentes, com o que a tradição perpetuou na memória regional: não foram apenas as circunstâncias provocadas pelo seu rapto como também, partira dela a sugestão feita, com autoridade, ao Ouvidor, para que fizesse o pedido a Dom João VI. É dessa forma que o fato aparece, muitas vezes, representado quer pela tradição oral, quer pela literatura que a incorporou e ampliou.

Assentada essa questão, o que se pergunta é se o que motivou Beja justificaria a sua heroificação. Parece ser impossível ter sido ela movida por ideais políticos ou qualquer outro ligado às questões de identidade ou legitimidade, como os alimentados durante tantos anos pelos moradores locais, ou ainda pela idéia de reparação por perda de tão ampla extensão de terras injustamente separadas da Província de Minas. Diante das suas condições existenciais, essas hipóteses estariam descartadas.

Não se pode saber, supõe-se apenas, se Beja tinha a capacidade de se imaginar como uma figura heróica, o que seria uma forma de sobreviver à situação que lhe fora imposta e que apontava para um destino pouco promissor. Caberia a ela inverter o curso de sua história, direcionando-o para um padrão mais edificante.

Feita a escolha, restava colocar em prática a experiência social conquistada ao lado do Ouvidor e suas habilidades naturais para exercer o poder de decisão nos assuntos da Ouvidoria.

Essa é a impressão que mais se aproxima dos muitos relatos feitos sobre Beja, nos quais ela é representada como uma figura forte e corajosa. Ao revelar em suas atitudes a força e a coragem, atributos imprescindíveis aos heróis, a jovem vitimizada transforma-se em heroína e, como tal, teria atuado no episódio que devolveu a Minas as suas terras.

É como heroína histórica, portanto, que Beja passaria da memória preservada pela tradição oral para o relato histórico, publicado pelo Correio de Araxá (Montandon, 2004, p. 99). 
Periódico semanal, o Correio de Araxá trouxe para os seus leitores, na forma de folhetim, a história de Araxá, na qual Beja aparece como protagonista. A publicação teve início em Março de 1915 e atendia às necessidades políticas e sociais daquele momento. Uma delas estaria relacionada com a questão do fortalecimento da identidade regional, tema suscitado pela aproximação do centenário da reintegração do Triângulo Mineiro a Minas, a ser comemorado no ano seguinte (Montandon, 2004).

Assinada pelo jornalista Clodion Cardoso e pelo historiador araxaense Sebastião de Afonseca e Silva, Subsídios para a História de Araxá e duas palavras sobre o Triângulo Mineiro, assim se intitulava a matéria jornalística, obteve à época grande repercussão junto ao público (Montandon, 2004). Pode-se dizer que esse sucesso resultou da habilidade dos autores ao associar a recuperação do passado com um enredo comovente, próprio às abordagens feitas nos dramas de vida, aos quais se adequava perfeitamente a trajetória de Beja, rica em implicações sentimentais.

Junte-se a isso, o fato de Beja representar uma personagem real, há muito presente na memória do povo, em que fora instalada pela tradição oral, validada por testemunhas que a conheceram, o que afastou a impessoalidade dos fatos registrados pela história, tornando-os mais próximos e atraentes.

Não se pode deixar de acrescentar, como um dos aspectos responsáveis pelo sucesso da introdução da Beja, heroína histórica, num veículo de comunicação, a estratégia editorial, própria do gênero folhetinesco, adotada pelo Correio de Araxá:

Outro aspecto a ser destacado diz respeito à estrutura do jornal, onde a história recebeu um espaço e uma formatação estratégica que facilitaria sua permanência. Como no sistema de fascículos, sempre era publicada no rodapé, com as folhas numeradas alternadamente na frente e no verso, e com largas margens, o que permitiria ao leitor recortá-la para sua encadernação. (Montandon, 2004, p. 98)

O certo é que a recepção positiva dos leitores do Correio de Araxá assegurou a continuidade de Beja como heroína histórica e, diante disso, as questões anteriormente levantadas sobre a motivação pessoal que a levou a participar na questão territorial mineira deixam de ter importância. Daqui para diante, mesmo sem documentos que pudessem ser confrontados com os fatos constantes do relato histórico, apresentado pelo jornal, foi incorporada à imagem de Beja, a que já se atribuíam múltiplas formas, a condição de heroína, 
que seria desdobrada nas representações dela feitas, posteriormente, perpetuando-se nas histórias de sua vida.

O avanço no tempo permitiu uma validação de um fato do passado.

Chegara ao fim a permanência de Beja em Paracatu, assim como a sua ligação com o Ouvidor. Da jovem inexperiente que aí chegara, não existia lembrança. Beja transformara-se em mulher poderosa, quer pela independência adquirida mediante a acumulação de respeitável patrimônio, quer pela determinação com que enfrentara e mudara as imposições do destino adverso às quais fora submetida.

Quanto aos motivos que a fizeram partir, alguns diziam respeito às mudanças nos panoramas político, social e econômico do Brasil, e que por ser o Dr. Mota um homem público, tiveram efeito sobre sua permanência em Paracatu.

Em 1815, o Brasil deixa de ser vice-reino. Foi elevado à categoria de Reino Unido a Portugal e Algarves, pelo Príncipe Regente D. João, em cumprimento da sugestão feita pelo Congresso de Viena. Tornava-se, portanto, parceiro de nações européias, participando das novas relações econômicas resultantes do processo iniciado com a Revolução Industrial. Isso significava a possibilidade de progresso e modernização, pela apropriação dos novos modos de produção, conseqüente aumento de consumo e mudança nos padrões culturais. Essas transformações passaram a ser vistas como metas para a inclusão da antiga colônia numa nova era, que representava um salto em direção à emancipação nacional e, por muitos brasileiros, à sonhada independência.

O Ouvidor expressa num comentário feito à Beja, sua preocupação com os novos ares:

Estou com um pressentimento de que o Brasil vai ficar, em breve, separado de Portugal. Vejo o trabalho dos brasileiros em São Sebastião do Rio de Janeiro. São estadistas, isto são. Há Deputados muito brilhantes: os de Minas Gerais, por exemplo. Não sei, mas não vejo boas coisas no horizonte. Umas nuvens... (Vasconcelos, 1985, p. 135)

Para ele o fato de estar longe da corte significava não participar diretamente das mudanças que ocorriam em larga escala, perdendo com isso a possibilidade de maior visibilidade e reconhecimento pelos méritos de seu desempenho no cargo da Magistratura, o que poderia lhe valer uma posição mais importante, no cenário político em efervescência.

Ainda, no ano seguinte, a morte de Dona. Maria I, rainha de Portugal, Brasil e Algarves e a coroação do príncipe regente Dom João, como seu sucessor, com o título de 
Dom João VI, acrescentaram mais preocupações à rotina do Ouvidor, aumentando suas inquietações quanto ao futuro do Brasil e consequentemente quanto ao seu. Apesar das boas relações que mantinha com a família real, o isolamento provocado pelo exercício de sua função, deixara-o fora do círculo que privava da companhia de Dom João e do Príncipe Pedro, o que para o Ouvidor era muito importante, tanto para o seu prestígio pessoal como profissional.

Em Paracatu, nos atos oficiais que marcaram esses acontecimentos, conta-se que Beja compareceu, ao lado do Ouvidor, sobressaindo-se pelo seu porte de rainha e pela riqueza de seus trajes.

Não é difícil imaginar o que levava uma cortesã a se portar de forma singular. Basta que se lembre da desaprovação social que a sua condição despertava, o que a fazia desenvolver uma percepção mais sutil de como se conduzir e representar de forma irrepreensível o seu papel, nem sempre fácil. Ora, se as posições sociais se expressam pela representação, tratava-se, no caso das cortesãs, não só de ter uma postura exemplar, como também de desenvolver uma preocupação minuciosa com todos os detalhes que compõem uma representação convincente, capaz de superar as censuras e resistências que marcavam as suas aparições públicas.

Esse talento parecia ser uma característica própria das cortesãs, o que se pode comprovar, embora o fato tenha se dado em outras paragens, com diferentes padrões culturais, mas em tempos semelhantes, no trecho que se segue:

Quando Edwige Feullière foi criticada em Londres por representar a cortesã Marguerite em La Dame aux Camélias como se fosse uma grande dame, ela reagiu dizendo: "As cortesãs da França foram as únicas grandes dames." (Griffin, 2003, p. 104)

E Beja era uma dama. Muito se ouviu e ainda se ouve falar sobre sua figura de "imponente dignidade". Fica claro que ela sabia ou mesmo sentia não ser aceita pela ordem social vigente. Daí ter-se esforçado para aprender todo o cerimonial de boas maneiras que lhe foi disponibilizado na convivência com o Ouvidor. Tratava-se provavelmente de uma tentativa de superação da situação que lhe fora imposta, e que entendeu ter de administrar no sentido de minimizar os efeitos negativos, como o da exclusão social, no seu caso velada, dada a influência do Ouvidor. De qualquer forma, seria essa maneira singular, pautada por atitudes próprias de uma dama, que marcaria sua figura daqui para diante, ao deixar o Dr. Mota e voltar para São Domingos de Araxá. 
Chegara a hora de voltar. Para ele, o momento político talvez tenha sido o fator determinante. Diz-se também, que a sua família, esposa e filhos, solicitaram a Dom Pedro que antecipasse seu retorno, preocupados que estavam com os ecos da aventura amorosa prolongada que chegaram à corte, trazidos com o atraso próprio das comunicações entre o sertão e o Rio de Janeiro.

Pensara em levar Beja. Apesar de sentir que o ato tresloucado que cometera, motivado por uma paixão inexplicável, levara-o longe demais, ainda nutria pela moça uma forte atração, mesmo não sendo correspondido.

Levá-la significava prolongar o prazer de tê-la aos seus pés como uma cortesã invejável, o que atiçava a sua vaidade de homem maduro e sem muitos atrativos. Por outro lado, a presença de Beja na corte, cercearia a sua mobilidade de homem palaciano, além de exigir tempo e dinheiro para instalá-la e mantê-la como amante. Beja tornara-se ambiciosa e possuía temperamento forte capaz de trazer-lhe muitos transtornos caso não fosse atendida em suas vontades e determinações.

O mais indicado seria voltar só, resolvendo antes da partida as questões que pertenciam a sua passagem pelo Sertão do Novo Sul, e que não faziam parte da sua realidade e do que esperava para a sua vida. Certamente para um homem como ele, de tão alta estirpe, uma carreira de sucesso e conquistas outras seriam a recompensa ideal e, nessa trajetória, não caberia Beja. Estava decidido, partiria só.

Para ela, a separação era, há muito, esperada. Tanto é verdade que nos últimos tempos vividos em Paracatu do Príncipe, preocupou-se de forma metódica e objetiva em amealhar recursos suficientes que lhe garantissem vida confortável, em que não faltasse o requinte a que se habituara nos dois anos que aí passara. Acredita-se que assim agira por saber da solidão e do vazio que aguardavam uma mulher, como ela, sem bens.

Restava-lhe, como alternativa, tornar-se independente o suficiente para salvar-se da humilhação do papel secundário que lhe fora imposto, e dedicar-se ao que ainda não sabia ao certo. Porém, independente do que fosse, uma ocupação ou um outro relacionamento, a sua dignidade e bem-estar deveriam ser mantidos. Uma evidência de que era essa a intenção de Beja foi a sua iniciativa, depois de ter abandonado a vida mundana, de aventurar-se em empreendimentos ligados à cata de diamantes, em Estrela do Sul, não só para manter-se ativa, mas como forma de ampliar seus recursos e manter sua autonomia econômica e social. 
Portanto, a questão da autonomia parecia ser central no desfecho desse episódio vivido contra a sua vontade no qual encontrou um legado existencial inestimável, que a armou para enfrentar um mundo que não se lhe apresentava como o melhor, porém era o único existente para acolhê-la após sua marcante experiência como cortesã do Ouvidor.

Não tinha idéia de como seria recebida em São Domingos de Araxá, por aqueles que a cercavam de carinho e consideração antes do seu rapto. Pelo que se sabe, nesse longo período de isolamento, poucas notícias tivera do local e das pessoas conhecidas que lá deixara, mesmo porque tudo que se referia ao seu passado, estranhamente, ficara ausente da sua nova vida. Supõe-se que devido às circunstâncias traumáticas em que se dera o início do relacionamento e que marcara a ambos, Beja e o Dr. Mota, tenha partido dele a orientação para que possíveis notícias ou contatos fossem abolidos, facilitando assim a convivência com a amante. Mesmo assim é para lá que iria.

Restavam à Beja, fazer e pensar o que lhe fosse mais conveniente. Nesse caso, acompanhar o Ouvidor à corte seria o mais indicado. Porém, continuaria a aceitar passivamente o papel de subordinação que a situação exigia e não era o que queria. Além disso, prolongar por mais tempo a convivência com o Ouvidor, parecia-lhe impossível. A sua indignação que ficara amortecida diante da impossibilidade imediata de qualquer decisão contrária à vontade de seu raptor, surgia com a força necessária para que, mesmo insegura quanto ao seu futuro, pudesse colocar-se no caminho oposto ao que seria por ele tomado, em direção ao Rio de Janeiro.

Fechado o acordo e após intermináveis preparativos para a dupla viagem, a do Ouvidor para a corte e a de Beja para São Domingos de Araxá, deixaram para trás a cidade e as lembranças, que dela não queriam levar. Da memória dos viajantes e de sua permanência em Paracatu, os documentos não deram conta, ficando apenas o que a tradição oral transferiu para os relatos históricos ou não, que se multiplicaram muitas vezes numa mistura de história e ficção.

Da riqueza que Beja acumulara, como se viu, ao buscar a autonomia que lhe permitiu assumir o seu próprio caminho, conta-se que:

(...) Beja se pôs a arrumar de novo as malas. Na canastra grande, de couro taxeado de chatos pregos dourados, guardava os presentes. Lá estavam os 9 litros de ouro em pó, em garrafas brancas; a caixa de madeira onde guardava as 30 barras de ouro cunhado na Vila Real de Nossa Senhora da Conceição de Sabará. Cada barra pesava 250 gramas e tinha aberto, no ouro escuro, o cunho Real. Num saco de seda estavam os cordões também de ouro, 
presentes e compras. O baú de pepitas maiores estava quase cheio. (...) A pepita mais preciosa era uma de 720 gramas (...). Num frasco de boca larga estavam seus diamantes. Esse frasco era de um litro e as gemas foram, umas compradas, outras, mimos à jovem. (...) Sua caixa de anéis, broches, alfinetes, camafeus, brincos, pulseiras e moscas de ouro fino, fabricação do arraial do Tijuco, eram espetaculares. Havia ainda nesse depósito de coisas belas, duas caixinhas de rapé, uma em marfim com fios de esmeralda sem jaça, ao longo das junções das peças, com um brilhante querosene no centro da tampa. A outra era de esmalte azul, com 19 brilhantes grandes, distribuídos pelas faces do conjunto. (Vasconcelos, 1985, p. 140)

Ao que se juntava um bom dote em moeda corrente, prataria, porcelanas, cristais, a mobília que guarnecia seus aposentos, cortinas, objetos de arte e seu principesco guardaroupas.

De todas as peças que levava, Beja tinha especial predileção pelas caixas de música. Possuía duas, uma que lhe fora dada pelo Vigário Melo Franco e, outra, pelo Dr. Mota. Ambas reproduziam trechos de música clássica, sendo as de Mozart as que mais a agradavam. Foi em Paracatu que apurara seu gosto musical, ao assistir representações de óperas, o que era raro no Sertão do Novo Sul. Essas lembranças não seriam esquecidas, sendo relatadas, mais tarde, aos que a acompanharam na velhice.

A longa viagem de volta, o trajeto entre Paracatu e São Domingos de Araxá levava cinco dias, foi empreendida por Beja, acompanhada por seus quatro escravos, uma tropa de onze burros, que carregavam a bagagem e quatro carros de bois onde foram acomodados os seus pertences mais pesados (Vasconcelos, 1985).

Ao chegar, Beja encontrou o que já previra: a hostilidade e a desconfiança com que eram tratadas mulheres as quais, como ela, representavam uma ameaça para a ordem estabelecida, aparentemente rígida.

No entanto, a curiosidade despertada pelo acontecimento, o retorno da Beja que, diferentemente do que se esperava, não voltava acabada e proscrita após o desenlace com o Ouvidor, mas renovada em sua beleza e firme em seus propósitos de viver com a dignidade possível a sua situação, mudou a recepção fria e distanciada que no início a isolou.

A notícia se espalhou com rapidez e muito se comentou sobre a riqueza que trazia em tão volumosa bagagem, especulando-se sobre como ela teria ido parar em mãos de quem, já nesse momento, havia fugido com o Ouvidor, não se importando com a morte do avô, por ele provocada, e não merecendo, portanto, voltar "vitoriosa". 
As circunstâncias recriadas e ampliadas pela idéia de escândalo, motivadas pela presença indesejável da Beja cortesã, que como tal deveria ocupar o seu lugar na sociedade, inviabilizaram a aceitação da Beja que conheceram e, até então, enquanto distante das suas vistas, vítima de um inescrupuloso Ouvidor.

Não ficara claro, para os que determinaram seu destino, a contradição provocada pelos padrões relativos a sexo e dinheiro, gênero e classe, presentes na situação ora analisada, que geraram uma controvérsia sobre a situação de cortesã imposta a Beja. A distinção dada ao papel, que acreditavam ser o único possível para ela, pelo considerável patrimônio que ostentava ao chegar, não condizia com o das mulheres que se dedicavam ao meretrício, nem ali nem na maioria das vilas que conheciam no Sertão do Novo Sul. Salvo algumas exceções, essas mulheres não obtinham riquezas ou qualquer favorecimento que permitissem uma vida mais digna.

Não se tratava, portanto, de uma questão que se restringisse a uma classificação de fundo exclusivamente moral ou de enquadramento social. Tratava-se de como lidar com uma mulher que, pelos indícios apresentados, parecia ter criado para si uma situação particular, na qual o poder e a independência muito se assemelhavam à condição do homem, já que a condição feminina estava atrelada à dependência financeira e à subordinação a disciplinas rígidas, fatores que inibiam qualquer traço de liberdade.

Vê-se então que se Beja colocava numa posição social distinta tanto das mulheres de família como das mulheres prostituídas.

Não encontrou em São Domingos de Araxá o lugar que deixara. Mesmo a fantasia que alimentara de longe, de reencontrar Manoel Fernandes de Sampaio, se desfizera. Ele havia se casado, poucos meses antes, com Anna Felizarda de Resende.

Instalou-se, provisoriamente, numa casa de aluguel, ao mesmo tempo em que iniciou a construção de um sobrado, na Praça da Matriz, onde moraria até sua partida para Bagagem, muitos anos depois. Essa casa é hoje conhecida como Sobrado da Beja.

Assumiria o seu papel de transgressora, mas a punição pela injustiça sofrida seria modelar, revelando-se na maneira como sua presença na pequena vila alteraria os hábitos locais e na forma como se transformaria, posteriormente, em figura respeitada.

De há muito foram descobertas nas proximidades de São Domingos de Araxá fontes hidrominerais. Embora se desconhecessem os efeitos medicamentosos das águas, foram reconhecidas por sua pureza e pelo bem-estar que proporcionavam aos que dela se serviam: 
garimpeiros do garimpo de Desemboque, já no século XVIII; criadores de gado que traziam seus rebanhos para a salga no Barreiro, ${ }^{4}$ o qual pelos seus efeitos benéficos, atraía fazendeiros de outras localidades. A prática ficou de tal forma concorrida que foi necessário, no início do século XIX, uma ordem régia para regular a salitração dos rebanhos (Vasconcelos, 1985).

A Fonte da Jumenta, como era conhecida, beneficiava moradores locais e os que vinham de longe em busca de saúde, mesmo ignorando serem radioativas as suas águas, o que mais tarde seria comprovado, após a descoberta do rádio, em 1896.

Agripa Vasconcelos narra o ocorrido com o médico mineiro, residente em Barbacena, Dr. Camilo Armond, Conde de Prados, formado em Montpelier, curado de impaludismo pela ação das águas araxaenses, registrando de forma curiosa o alcance geográfico da fama das águas mineiras.

Cansado das muitas tentativas feitas para curar-se, dirigiu-se à França para consultarse, ouvir opiniões de outros colegas que pudessem livrá-lo da doença, tida como incurável. Ouve então, o seguinte veredicto: "Só em um lugar no mundo o senhor se curará. Esse lugar é muito longínquo, na América do Sul. Chama-se Araxá, no Reino do Brasil...” (Vasconcelos, 1985, p. 176).

Ao voltar, Beja, que conhecia o local de quando lá ia acompanhada do avô, iniciou um hábito que manteria para sempre: as idas diárias ao Barreiro. Não só se servia das águas da fonte bebendo-as, como era costume dos que ali iam, como também se banhava na lagoa, beneficiando-se da ação das lamas radioativas, ao deixá-las secar em seu corpo, terminando o ritual nas águas límpidas da fonte.

Iniciava assim, uma prática, mais tarde afiançada cientificamente, a crenoterapia ${ }^{5}$, que permitia, como ela mesma dizia, rejuvenescer-se e manter-se saudável ${ }^{6}$. Como sua beleza e energia eram referências para os padrões da época, Beja tornou-se a responsável pela utilização das águas para essas finalidades, até então despercebidas pelos que delas se serviam. Ao mesmo tempo em que popularizava as águas do Barreiro, transformava-se numa figura mais popular. Seus gostos e preferências passaram a ter aceitação na comunidade local,

\footnotetext{
${ }^{4}$ Para se chegar às águas minerais, passava-se por um barreiro, daí a denominação que se manteve também no hotel, construído pelo governo estadual: Grande Hotel do Barreiro. As obras tiveram início em 1938, prolongando-se por seis anos e após passar por um longo período de declínio e, posteriormente, por total restauração. Encontra-se hoje em funcionamento.

${ }^{5}$ Tratamento pelas águas minerais.

${ }^{6}$ Das águas minerais do Brasil, são as de Araxá que contêm o maior teor de rádio.
} 
que a imitava, fazendo deles parte de seus costumes como no caso das águas e em tantos outros.

Beja não se escondia. Precisava mostrar-se e, sendo assim, montava cuidadosamente os cenários que deveriam compor suas aparições.

Pode-se dizer que as suas incursões diárias ao Barreiro serviam-lhe como um palco no qual representaria o seu papel de cortesã, agora assumido e, portanto, o faria numa forma inesquecível, a do espetáculo.

É com cuidado que Beja o prepara. Dos figurinos ao aparato cênico, tudo deve concorrer para que a ação desenvolvida desperte emoção e surpresa na numerosa platéia que, aos poucos, foi se tornando cativa: para si, o papel principal, o da sedutora, desempenhado com perfeição. Na cadência controlada do "a passo" de seu cavalo, vestida com elegância e recato, Beja passa seguida por seus escravos. A cena, sem palavras, diz tudo ao espectador que, alimentado pelas imagens, aguardará a próxima apresentação. O fator surpresa ficava a cargo da história que se contava e que emprestava à cena um realismo inusitado. Beja escolhia o seu parceiro para a próxima noite durante o trajeto, para isso, atirava no alvo uma flor vermelha.

A cena que se desenrolava no percurso do Barreiro e o ritual dos banhos foram responsáveis, posteriormente, pela apropriação de sua figura como representação simbólica da saúde e da beleza proporcionadas pelas águas minerais. Em seu tempo, foram responsáveis pelo encanto e fascínio com que passou a freqüentar o imaginário popular.

A Fonte da Jumenta seria um dia a Fonte Dona Beija, como o é até hoje. Como personagem central, Beja continua a representar o seu papel inesquecível, em murais que decoram a fonte, as termas e o Grande Hotel do Barreiro. Num deles, lê-se a legenda: "1800. A fama e a beleza de D. Beja venciam as distâncias e traziam para Araxá admiradores residentes nas mais afastadas regiões do país. 1890.”

E era o que ocorria.

Por esse tempo, o sobrado, da praça da Matriz, já estava concluído e montado com requinte. $O$ que não trouxera de Paracatu, Beja mandou vir da corte. Para os que a freqüentavam, a casa da Beja era motivo de admiração pelo bom gosto e o luxo que transpareciam nos detalhes, tanto da decoração, como do aparato com que recebia os seus convidados. 
Passavam por seus salões os homens mais importantes de São Domingos de Araxá, entre os quais fez bons amigos, que a assistiram em seus negócios e nos momentos em que precisou de apoio. Outros vinham de fora atraídos pela fama de Beja e pela sabida sensibilidade que tinha no trato com os homens.

Sua casa tornou-se o centro da vida social, essencialmente masculino, do arraial e suas vizinhanças. Isso não significava que os que lá iam buscavam apenas a satisfação de seus desejos, instigados pelas fantasias eróticas provocadas por aquela presença tão deslocada dos papéis femininos convencionais. Ou mesmo porque viam na singularidade daquela mulher um atrativo a mais para uma aventura fugaz ou uma noite de amor reservada, como já se sabia, para aquele que fosse por ela escolhido. Além do sexo, Beja proporcionava, a seus convidados, reuniões agradáveis, regadas a bom vinho que acompanhavam um cardápio sofisticado.

Nessas ocasiões compartilhava com os convivas sua sutileza e inteligência criando uma atmosfera de plena liberdade intelectual. De tudo se falava. Os temas eram variados. Da política local às mazelas do reino, dependendo da identidade dos presentes.

Livre no comportamento e nas conversas, a presença de Beja transformava o ambiente em prazer. Fosse pela forma como conduzia a conversa, fosse pelo caráter sedutor que imprimia em seu comportamento e, principalmente, pela sua aparência. Vestia-se bem e com originalidade. $\mathrm{O}$ que quer que colocasse sobre o corpo, agradava aos olhos, mas poderia ser interpretado, talvez numa intencionalidade expressa, como acessório natural de sua superioridade. Assim, o que poderia ser excesso em brilho, textura e cor, lembrava a todos que a olhassem a sua riqueza, além de indicar o modo como a conquistara. Para tal, desenvolveu um estilo próprio, no qual não faltava a percepção do espírito da época, ficando marcado por simbolizar a independência feminina, uma condição que a colocava à frente de seu tempo.

Vê-se por que o guarda-roupa de Beja transformou-se em motivo de cobiça e inveja tanto para as mulheres respeitáveis, como para as suas concorrentes, entrando para a história como uma de suas armas. As barreiras e distinções de classe eram por ela desafiadas e ficavam comprometidas diante da cortesã que se sobressaía por se vestir tão bem. Essa habilidade cultivada por Beja, com traços de requinte e vingança, ajudou-a de certa forma, com o brilho do seu vestuário, a atrair a atenção de homens e mulheres, compensando-a pela estreiteza de seu território social. 
A propósito da importância que Beja dava à moda, a tradição registrou passagens significativas. Uma delas refere-se a um fato que demonstra a sua presença de espírito para lidar com situações provocadas pelos seus adversários. Nesse caso, Candinha da Serra, sua concorrente.

Sabendo que a despeitada mulher mandou espioná-la, para copiar-lhe o traje com que iria à missa no próximo domingo, Beja não se fez de rogada, deixou-se espionar. Porém, quando Candinha apareceu na Praça da Matriz trajando a sua cópia, certa do constrangimento que causaria à sua inimiga, Beja encontrava-se vestida com outro figurino, mas suas escravas que a acompanhavam, estas sim, estavam usando modelos idênticos ao de Candinha.

$\mathrm{O}$ efeito fez-se sentir marcando definitivamente as diferenças existentes entre as duas mulheres. Ficou claro que Beja demarcara seu espaço, utilizando-o de forma a não se confundir com as demais que, como ela, tinham a mesma classificação. Não houve mais hostilidade ostensiva no que se relacionava às atividades comuns a elas, e a distinção no vestir tinha atuado como fator decisivo nessa questão, que assim se encerrou.

Algumas vezes, Beja tendia para a originalidade, porém sem cair no grotesco. Usava-a de forma equilibrada e, sobretudo, para obter efeitos especiais.

Foi assim que, numa certa ocasião, para causar sensação em sua platéia masculina, apresentou-se vestida com discrição, deixando para o arranjo dos cabelos o toque final, causador da surpresa que contagiou os presentes.

Uma vaporosa boina de renda frouxa, ainda verde, lhe envolvia a cabeça bem posta no pescoço branco. Debaixo dessa boina, em saquinhos pequenos de crivo de seda alva, moviam-se, presos, vários vagalumes de luzes amarelas, verdes, azuis. Quando ela movia a cabeça, naturalmente, viam-se-lhe as luzes dos lampírios, luciluzindo nos cabelos. (Vasconcelos, 1985, p. 148)

A sua capacidade em criar uma atmosfera adequada aos seus propósitos de encantamento e sedução, na tarefa de fazer-se cercar por homens capazes de proporcionar-lhe uma vida de luxo e prazer, deu a Beja resultados inesperados. Ao mesmo tempo em que via aumentar o seu patrimônio, expandia suas relações. A associação desses fatores, sociabilidade e lucro, respondeu pelo seu sucesso e fama na carreira recentemente iniciada.

Aos poucos, a presença daquela mulher indesejada foi-se firmando. Após a divulgação, da qual se encarregaram seus fiéis amigos e constantes convidados, de sua 
participação na questão territorial mineira, a Beja heroína passou a conviver com a Beja cortesã e deram-se muito bem.

O feito era respeitável para uma mulher. Ela mesma, colocando em prática o que aprendera, no curto período em que tivera uma vida mais privilegiada, ao lado do Ouvidor, criara uma conexão benéfica entre os seus dois papéis, o de heroína e o de cortesã, possibilitando um equilíbrio entre o bem e o mal, o que tornou sua posição mais confortável.

E lá se encontrava ela, numa proximidade que despertava o fascínio e o desejo dos homens e a ira das mulheres, respeitáveis ou não. Ao que parece, houve um acordo tácito entre as partes após reconhecida a superioridade da força de Beja e as evidências de que sua permanência era fato consumado, representadas pela construção do sobrado, já em funcionamento e, para completar, por um novo projeto que Beja engendrava, a Chácara do Jatobá. Podem ter sido esses sinais exteriores palpáveis além da repercussão das reuniões festivas promovidas por Beja, traduzida em comentários fantasiosos, que geraram uma atitude conjunta das personalidades femininas mais expressivas da sociedade araxaense.

O fato ficou assim registrado, tendo sido transmitido oralmente, com algumas alterações, de uma geração a outra. Hoje, faz parte das histórias de Beja como a que aqui se conta.

Numa tarde em sua casa, Beja foi avisada por Severina que ali se encontrava um escravo de distinta senhora, que desejava entregar-lhe um presente por ela enviado. Beja que apesar de suas realizações, não esquecera o desencanto que tivera ao voltar para São Domingos de Araxá, pensou que, talvez, o presente representasse uma possibilidade de reaproximação com as pessoas que tanto prezava e que não mais faziam parte de sua vida. Atendeu-o prontamente e pôs-se a abrir a caixa cuidadosamente embrulhada. Suas esperanças logo se desfizeram diante do conteúdo e das intenções que representava. Na caixa além de estrume, um cartão: "Para a cortesã do Ouvidor."

Retribuiu pelo mesmo portador. Após limpar a caixa, colheu rosas brancas em seu jardim, arranjou-as com cuidado e pediu a Severina que escrevesse um bilhete: "Cada um dá o que tem".

O presente simbolizou para Beja a ruptura definitiva com o meio a que pertencera e para o qual não haveria de voltar. As tentativas que fizera para restabelecer uma situação impossível, como a do passado e que fora idealizada por ela no intuito de minimizar as 
sucessivas perdas afetivas que enfrentara, terminaram com a humilhação pretendida e a resposta pronta com que a afastara.

Não acreditava no destino como único elemento responsável na mudança do curso de sua vida. As circunstâncias interferiram nessa orientação e exigiram a cada alteração uma resposta possível. Esse era o momento em que a resposta não seria apenas possível, mas definitiva, reorientando seu trajeto na direção por ela definida, que por ser contrária à ordem estabelecida, acentuaria na Beja transgressora os traços da determinação e da busca constante de independência, presentes em sua trajetória.

Lá estava sua casa, plantada no largo da Matriz e as obras da Chácara do Jatobá chegavam ao fim. A residência ficou pronta em 1818, assim como o que planejara para o seu entorno, pomar e jardim. Beja mantivera na chácara, como na construção do sobrado, o princípio do conforto aliado ao bom gosto na montagem dos ambientes, além dos sinais de opulência com que fazia acompanhar tudo que se relacionasse à sua figura.

Nesse sentido, pode-se intuir que Beja agisse de forma intencional, usando desse artifício - o da exteriorização de suas riquezas - para firmar-se no campo das realizações econômicas, fato incomum no terreno feminino. Esse traço passou a fazer parte dos predicados que lhe atribuíam, acrescentando admiração e respeito nas impressões que causava a todos que a conheciam.

Para a Chácara do Jatobá ou Chácara da Beija, como ficou conhecida, Beja reservou propósitos estritamente comerciais (Montandon, 2004). Seria lá que receberia os muitos admiradores, em festas e saraus cuidadosamente organizados para esse fim e que seriam responsáveis pela renda com que pretendia manter-se, além de atender, o que percebeu ser possível, diante dos resultados obtidos após seu regresso, ao seu desejo de fazer fortuna própria e garantir sua segurança futura.

As atividades funcionavam conforme as regras por ela determinadas, que dosavam, na medida certa, limites e expectativas daqueles que delas participavam.

Nem o valor fixo cobrado à entrada, duzentos mil-réis, valor expressivo para a época ${ }^{7}$, ao qual não estava vinculada a realização da intenção da maioria dos que lá iam passar a noite em companhia de Beja, diminuía o número de admiradores que, cada vez maior e a cada dia, iam à chácara. Entre eles, os trazidos pelas descobertas de novas lavras de diamantes, que

\footnotetext{
${ }^{7}$ Para se avaliar o que representava a cifra, o grama de ouro custava, nessa época, um mil-réis (Leonardos, 1986).
} 
tornavam a rota Rio de Janeiro, São Paulo, Goiás constantemente movimentada, passantes que levavam para seus destinos as lembranças do Jatobá, encarregando-se assim da divulgação da presença de Beja no distante arraial de São Domingos de Araxá.

As visitas eram previamente agendadas por Severina. A escrava tornara-se a confidente de Beja e cercava-a de cuidados maternais. Não só por isso, mas por ser de inteira confiança e, das pessoas mais próximas a Beja, a única, como já se viu, que sabia ler e escrever, a escrava passou a desempenhar um papel fundamental no empreendimento do Jatobá. Além dela, os outros escravos que serviam Beja acompanhavam-na e cuidavam da sua segurança, obedecendo suas normas quanto ao comportamento dos convidados.

Beja prosperava e administrava a sua profissão com a mesma determinação com que o fizera no tocante às condições anteriores. Em pouco tempo, a Chácara do Jatobá transformouse na principal atração de São Domingos de Araxá. Era lá que se encontrava o prazer. Beja era apenas parte dele. De resto, tudo contribuía para tal. A atmosfera cativante estava criada para os que se iam e para o que fosse escolhido para passar a noite.

Muitas são as passagens que marcaram esse período da vida de Beja, carregadas em fantasias; de paixões fulminantes; de fortunas perdidas; de presentes capazes de fazer inveja a uma rainha; de histórias em que o infortúnio andava par a par com a felicidade.

Numa delas, ocorrida num momento em que Beja dispunha-se a levar uma vida "respeitosa", Frieiro (1981) narra o seguinte:

Aos quarenta e oito anos deu por terminada a sua carreira de mulher alegre. Ainda se conservava bonita, mas cumpria-lhe levar vida decorosa: era mãe de duas jovens, educadas nos bons princípios e já casadas com pessoas de consideração social. Certo dia, entanto, refere a tradição, um rapaz cortejoua com insistência que chegou a impacientá-la. Vinha de longe e oferecia-lhe muito dinheiro. Ela aceitou, afinal, para se livrar do impertinente. Deu-lhe entrada em sua casa, à noite, e pediu-lhe que se despisse. Isso feito, a um sinal da dona da casa, entraram no quarto dois escravos. Subjugaram o moço e o moeram a pancadas, até que o atiraram na rua, nu, feito um molambo. (p. 178)

A maioria dessas passagens, não importa se ocorridas no início ou no fim do período da Chácara do Jatobá, traz em comum a representação da Beja mundana, mulher proibida, tentadora e pecadora, aquela que conduz ao descaminho e à perdição.

Pode-se perceber que, às suas imagens de vítima, de sedutora, de heroína, funde-se a da prostituta, que ganha retoques diferenciados quando da mudança do relato oral para a 
linguagem escrita. Nesta, Beja ganha contornos ora próximos aos ideais da mulher libertina e sem escrúpulos, ora aos da mulher virtuosa, involuntariamente transformada em cortesã, vítima das circunstâncias, do rapto inicial e da conseqüente rejeição social.

Importa que estava criada uma nova cultura do prazer. Pode-se dizer que uma variação sobre um velho tema, que foi por Beja interpretado com novos elementos, selecionados e acrescentados. O resultado ficou confirmado pelo que se sabe: Beja realizou-se plenamente em seu papel de "Mundana de Alto Coturno" (Dornas, 1942), realizando também os devaneios daqueles que buscavam, no Jatobá, algo além do que a mera satisfação de seus desejos.

Confirma-se também pela permanência da idéia de luxúria e poder que caracterizaram a Beja do Jatobá, tornando-a resistente ao tempo e às contínuas adaptações aos modos e costumes de novas gerações com suas exigências transformadoras.

Apresentam-se assim a Beja e o Jatobá no trecho dos versos do samba enredo, que a acompanhou pela avenida, num Carnaval Carioca, o de 25 de fevereiro de 1968. Beja representava o papel principal, em Dona Beija: a feiticeira do Araxá, apropriada pela alegoria carnavalesca, apresentada pelo Grêmio Recreativo Escola de Samba do Salgueiro ${ }^{8}$ :

Era tão linda, tão meiga, tão bela

Ninguém mais formoso que ela

No reino daquele Ouvidor

ela com seus modos inteligentes fez um reinado diferente na corte de Araxá / e nos devaneios da festa do Jatobá. ${ }^{9}$

No entanto, Beja vivia seus devaneios fora do Jatobá. Estava apaixonada por Sampaio. Passaram a se encontrar apesar de terem resistido por algum tempo, cada um a seu modo e levados por motivos, que pareciam tê-los afastado para sempre. Sampaio estava casado e tinha filhos. Beja transformara-se em mulher pecadora, distante daquela que um dia poderia ter sido a mãe de seus filhos.

Encontravam-se sem que ninguém soubesse, embora fato sabido de todos, no sobrado do largo da Matriz. Beja tornou-se a amante de Sampaio. Para os dois, a situação que a

\footnotetext{
${ }^{8}$ A escolha do enredo, baseado no livro de Thomas Leonardos, deveu-se ao sucesso obtido pela Escola de Samba do Salgueiro, com a apresentação, anos antes, da história de Chica da Silva, uma figura popular da história do Brasil, que conquistou o tão cobiçado primeiro lugar. Dona Beija e sua história cabiam perfeitamente nessa perspectiva e passaram às mãos de Fernando Pamplona, que desenvolveu o enredo, com figurinos de Arlindo Rodrigues e Marie Louise Nery. Izabel Valença, "a mais famosa destaque de escolas de samba da época", representou Beja, acompanhada pelos 2500 componentes do Salgueiro (Montandon, 2004, p. 128-129).

${ }^{9}$ http://www.galeriadosamba.com.br.
} 
princípio parecia satisfatória, tornou-se insustentável diante da impossibilidade de assumirem uma vida em comum, o que era aceitável para Beja, mas não para ele, que a queria só para si.

Sampaio que deveria representar a satisfação de um sentimento verdadeiro, não era diferente dos muitos homens que Beja conhecera. Apesar da ilusão de felicidade que o reencontro provocara, os desentendimentos dominaram o romance, trazendo problemas para a sua vida profissional e para a família de Sampaio. Apesar do desencanto, viram-se como amantes, por um longo tempo, aproximadamente dez anos, dos quais muito se fala e pouco se sabe.

Sabe-se, entretanto, que em 15 de fevereiro de 1819 Beja batizou sua primeira filha, Thereza Thomazia de Jesus, 10 "fruto anônimo de seu amor livre" (Pontes apud Leonardos, 1986, p. 105).

Thereza não tinha pai ostensivo, mas diz-se que era filha de Sampaio e que esse, ao saber de seu nascimento, propôs à mãe viverem juntos, no que não foi atendido.

Beja, passado algum tempo, retomara suas atividades, abrindo os salões do sobrado para os amigos e os do Jatobá, para os frequientadores habituais. Acrescentem-se à sua já conhecida rotina, as idas ao Barreiro e às missas domingueiras, também interrompidas durante o período de gestação.

Do ambiente doméstico e familiar, modificado pela presença da filha, Beja parece não ter feito parte. Pelo que se falou, talvez em função dos costumes da época, Thereza foi cuidada e amamentada por uma escrava, não interferindo diretamente no cotidiano da mãe, ou em suas possibilidades afetivas, como realização de suas tendências maternais, se é que as tinha.

Em meio a esse quadro de relativa tranqüilidade, no qual Beja mantivera-se com a mesma independência que a caracterizara antes de tornar-se a amante de Sampaio e antes da inesperada maternidade, os contratempos causados pela atitude cada vez mais inconveniente do homem, que continuava a visitá-la com freqüência, mesmo quando não era convidado, desgastavam Beja, fazendo-a mais distante do que um dia julgara pudesse ser sua felicidade.

As mudanças ocorridas por esse tempo no quadro político brasileiro, (o Príncipe Dom Pedro era agora o Regente, o que se dera após a partida de D. João VI e da Família Real para Portugal em 1821), pouco refletiram na vida daqueles que estavam longe da corte. São

\footnotetext{
${ }^{10} \mathrm{O}$ registro de batismo data de 24 de fevereiro de 1819, pasta 6, folha 54v. Arquivos da Igreja Matriz de São Domingos. Fundação Cultural Calmon Barreto. Araxá, MG.
} 
Domingos de Araxá continuava tal qual antes. Apenas os temas das discussões locais sofriam uma alteração temporária, até que outros, derivados de medidas mais recentes, passassem ao debate alimentado por aqueles moradores, tidos como mais bem informados. Assim, Dom Pedro e a Regência, assuntos dominantes no panorama local de 1821, cederam aos poucos espaço aos muitos acontecimentos que resultaram na proclamação da Independência do Brasil, em 1822, trazendo à maioria dos moradores, a sensação de realização de seus anseios patrióticos.

No Largo da Matriz, Beja abriu seus salões para receber as autoridades locais. Festejou-se a notícia da Independência, com todos os ingredientes próprios ao estilo da anfitriã, já conhecido dos seus convidados. Comungava com seus amigos as mesmas idéias e fora com eles que aprendera o suficiente para participar de conversas tidas como de domínio masculino, como as que tratavam de política. Era essa uma das suas habilidades. Talvez, a responsável pelo número sempre crescente de visitantes que iam não ao Jatobá, mas ao sobrado. Era aí o centro da vida social e cultural de São Domingos de Araxá e, ainda, se contava com a presença de Beja, perfeita como anfitriã e parceira nas conversas, das banais e privadas às que cobrissem assuntos mais complexos e públicos.

A vida de Beja dividia-se, assim, entre o Jatobá e o sobrado. Continuava adquirindo propriedades o que indicava uma próspera situação financeira. Muitos eram os seus relacionamentos amorosos, assim como também eram muitos os que se restringiam à amizade. A esse respeito, a passagem que se segue é esclarecedora: Entretanto, também houve outros tipos de relacionamento com homens,
considerados ilícitos diante dos costumes, e incomuns para uma mulher, mas
perfeitamente lógicos e necessários para alguém que, como ela, era
analfabeta e precisava ser representada, por não saber ler nem escrever, na
assinatura "a rogo" de documentos ou transações comerciais. Aparentemente
nem sempre essa função era feita por procuradores legalmente constituídos,
mas por amigos que deviam gozar de sua confiança... (Montandon, 2004,
p. 62)

Alguns deles gozavam de grande prestígio social e político e atenderam-na quando necessário, auxiliando-a na condução de seus negócios e orientando-a nas decisões pessoais. Esse apoio, prestado por figuras influentes, acabou por representar um papel importante na ascensão social de Beja, já conquistada parcialmente pela sua fortuna e seu poder. É provável que sem essas relações, em que a confiança parecia ser mútua, Beja não tivesse conseguido posteriormente casar suas filhas com homens respeitáveis e que, sobretudo, a respeitavam. 
Era essa a situação quando Beja conheceu o Dr. João Carneiro de Mendonça. "Jovem, esbelto e insinuante, portador de alta linhagem, com sangue nobre, nenhuma dificuldade encontrou, por meio de emissário para obter audiência de Dona Beija" (Silva, apud Leonardos, 1986, p. 114).

A experiência amorosa com Sampaio chegava ao fim e as aventuras vividas no Jatobá já lhe tinham rendido poder e autonomia suficientes para ocupar um espaço representativo na sociedade local, na qual certa dignidade foi atribuída à sua figura, Beja então resolve dedicarse ao que lhe pareceu ser um sentimento verdadeiro.

Apaixonou-se por João. Filho do Coronel João José Carneiro de Mendonça que privava de estreitas relações com Beja, o jovem João voltara a sua terra. Estivera primeiro em Caraça $^{11}$, onde completou parte de seus estudos e depois partira para Coimbra, dedicando-se às Ciências Jurídicas. Pretendia iniciar sua carreira como advogado em Paracatu, mas ao conhecer Beja, deixou-se ficar. Permaneceu em São Domingos de Araxá, acredita-se por muitos anos, sendo Beja o principal motivo da alteração de seus planos.

Tornaram-se amantes. João passou a ocupar na vida de Beja o espaço antes reservado a Sampaio. Era recebido no sobrado. Ele, solteiro, e Beja, livre de qualquer restrição que limitasse seu campo de ação, tiveram um romance prolongado e, de certa forma, estável. A situação confortável, de pleno conhecimento de todos, permitia ao casal uma liberdade que Beja desconhecia, a de ter um companheiro presente em seus passeios ao Barreiro e nas reuniões do sobrado. Por outro lado, mantinha sua autonomia, a de continuar comparecendo ao Jatobá.

Beja teve outra filha. Joana de Deus de São José nasceu em 1838 e "não teve nenhum pai que a assumisse oficialmente" (Montandon, 2004, p. 43).

Contudo, diz a tradição ser Joana, filha de João, assim como os indícios: "Exprimiria a coincidência do primeiro nome algum indício de sua ligação com João Carneiro de Mendonça?" (Leonardos, 1986, p. 115).

Ou ainda, o que poderia ser uma interpretação resultante da leitura de um documento oficial, a certidão de batismo de Joana, feita por Rosa Maria Spinoso de Montandon (2004):

(...) no registro de batismo, consta como seu padrinho o coronel João José Carneiro de Mendonça, a quem se poderia atribuir um parentesco com a

\footnotetext{
${ }^{11}$ Importante instituição educacional da província mineira, fundada em 1820, pelo missionário português Irmão Lourenço de Nossa Senhora, na Serra do Caraça. Funcionou por mais de 150 anos, formando várias gerações de políticos e estudantes da elite brasileira.
} 
afilhada ou, ainda, a paternidade, possibilidade também extensiva a um de seus filhos, o doutor João Carneiro de Mendonça, arrolado no mito como um dos amantes de Dona Beja. (p. 43)

A atribuição da paternidade seria, no caso, justificada por uma prática comum observada em documentos eclesiásticos do século XIX, em que o apadrinhamento de filhos ilegítimos, que não podiam ser assumidos publicamente, era feito por pessoas da família do suposto pai, o que criava um vínculo perene, representado pela responsabilidade assumida em ritual religioso (Montandon, 2004, p. 43).

De qualquer modo, Beja assumira a responsabilidade pela criação de suas filhas e fizera-a de maneira a encaminhá-las noutra direção que não a sua, possibilidade que seria considerada remota não fosse, como já se viu, sua posição social distinta, que não representava nem o ideal da mulher de família nem o da mulher prostituída. Por não se enquadrar nas classificações quer fossem de fundo moral ou social, Beja adquiriu o prestígio devido aos que se firmaram no campo das relações econômicas, presidido pela associação de sociabilidade e lucro, perfeitamente equilibrados nas suas atividades amorosas e profissionais.

Thereza e Joana não tiveram pais que as assumissem oficialmente, assim como Beja não conheceu o pai. Seu registro de nascimento traz apenas o nome de sua mãe. Porém, Joaquim, neto de Beja, que nascera no mesmo ano de Joana, era filho legítimo de Joaquim Ribeiro da Silva Botelho, com quem Thereza se casara em 1833. Beja tornara-se avó dois anos antes, ao nascer a primeira filha do casal, Theodora Jacintha Fortunata.

Joaquim Ribeiro da Silva Botelho, marido de Thereza, era irmão do Coronel Fortunato José da Silva Botelho, homem de destaque no cenário político da Vila de Araxá, ${ }^{12}$ onde a família possuía inúmeras propriedades rurais, sendo reconhecidos na região por seu poder político-econômico. Os Botelhos pertenciam ao grupo político "da Mandioca"13, constituído por famílias de prestígio que, conforme o costume, utilizavam o casamento entre seus membros como instrumento de fortalecimento de seus interesses familiares. Garantiam, dessa forma, suas propriedades rurais, responsáveis pela manutenção de sua hegemonia econômica, social e política.

Percebe-se na prática dos Botelho a aplicação do sistema de casamentos das classes mais abastadas da sociedade brasileira, no século XIX (D'incao, 1997). Porém, Thereza que

\footnotetext{
${ }^{12}$ O Arraial de São Domingos de Araxá foi elevado, por Lei Imperial, à categoria de Vila, em 1832.

13 A denominação refere-se à Fazenda da Mandioca, propriedade dos Botelhos, onde se concentravam as atividades do grupo político (Montandon, 2004).
} 
não representaria a mulher "ideal" para um dos Botelhos, casou-se com Joaquim, levando consigo um dote considerável proporcionado por sua mãe, Beja, que se viu assim aparentada com os Botelhos. Da mesma forma, anos mais tarde, Joana se casaria com Clementino Martins Borges, que tinha na Bagagem, onde vivia, tradição de homem de negócios bem sucedido.

Numa época francamente desfavorável para as mulheres, Thereza e Joana superaram as imposições que regiam as normas das alianças matrimoniais e foram legitimadas, por seus maridos, perante a sociedade. Acredita-se que os casamentos de Thereza e Joana, realizados de acordo com o modelo aqui apresentado, não ocorreriam não fosse a singularidade que marcou a trajetória de vida da mãe.

À época em que João Carneiro de Mendonça tornara-se amante de Beja, Sampaio não se conformara com essa situação, apesar de ter acabado a longa relação amorosa havida entre ambos. Conta-se que Sampaio teria incumbido dois escravos de surpreendê-la, numa manhã em que se dirigia ao Barreiro, para espancá-la. Apesar de fazer o percurso sempre acompanhada por Moisés e Severina, o ataque aconteceu sem que pudessem defendê-la. O que não passava de uma tentativa para amedrontá-la, quase lhe tirou a vida. Foram necessários alguns meses para que Beja se restabelecesse física e moralmente.

O fato não foi investigado, comentou-se que a pedido da vítima. Os autores da agressão desapareceram sem deixar rastro, mas ficou clara para todos, a identidade do mandante do crime: Sampaio. Talvez, porque Sampaio já fosse conhecido como homem de temperamento agressivo, motivo que lhe rendera, ao longo da vida, muitos desafetos e inimigos, mesmo sendo vereador (cargo do qual foi destituído após ser condenado, em uma ação judicial, como autor de ofensa e calúnia) e tendo atuado como Juiz de Órfãos. ${ }^{14}$ Também, podem ser considerados como indicadores da sua culpa, a situação provocada pela recusa de Beja em recebê-lo e sua ligação com o Dr. João Carneiro de Mendonça. Enfim, se a agressão tinha um caráter punitivo e ameaçador, com o objetivo de mudar o comportamento de Beja, Sampaio não foi bem sucedido. O episódio não a fez mudar de opinião. Sampaio foi afastado do sobrado, do Jatobá e de sua vida.

O afastamento só não foi definitivo, como Beja pretendia, porque Sampaio foi assassinado algum tempo depois do rompimento violento. Beja viu-se envolvida, como

\footnotetext{
${ }^{14}$ A atuação de Sampaio como vereador e Juiz de Órfãos pode ser comprovada nas atas da Câmara Municipal e documentos do poder judiciário, respectivamente (Montandon, 2004).
} 
mandante do crime, nas hipóteses levantadas sobre as circunstâncias em que se deu o fato, ocorrido

(...) no dia 13 de Junho de 1836, por volta das sete horas da noite, foi "despiadadamente assassinado" com uma bala e "treze caroços de chumbo grosso", disparados por uma espingarda, segundo consta no termo de abertura do inventário solicitado por sua esposa. (Montandon, 2004, p. 214)

Pelo que se sabe, o crime foi cometido por Antônio de Almeida Ramos, escravo alforriado e desconhecido na região, que alegou ao ser preso, ter sido contratado por Beja para executar Sampaio, suposto pai de Thereza, tendo recebido de suas mãos a quantia estipulada de 500 mil-réis, além da arma do crime.

Ao final de longo processo, tanto Beja como Antônio de Almeida Ramos foram absolvidos.

Ela, que tudo negou, e por não haver nenhum indício ou prova da acusação feita pelo assassino, passou por caluniada. Recebeu o apoio e a solidariedade de amigos ou meros simpatizantes, o que teria refletido no resultado favorável do julgamento: sua absolvição.

Ele, por ter ficado comprovado que teria matado em legítima defesa, pois Sampaio, num de seus rompantes, o teria esbofeteado e ameaçado, dias antes do crime. Depois de liberto, nunca mais foi visto.

A tradição assim registrou. Como acontece com os fatos que em seu tempo causaram grande impacto, a transmissão oral se encarregou das mudanças. Ora uma, ora outra versão com cortes ou com acréscimos foram incorporadas e legitimadas pela memória social, para serem posteriormente legadas às muitas traduções das vidas de Beja, por aqueles que delas se ocuparam.

Porém, causa estranheza que tal fato, o assassinato de um homem que gozava, na vila de Araxá, de influência social, política e econômica, não tenha deixado vestígios documentais diretamente ligados aos procedimentos investigativos e processuais, instaurados por ocasião do crime. Restou do assassinato apenas o registro dele feito em dois documentos relativos a processo de inventário e tutela de filhos, pela viúva da vítima, D. Anna Felizarda de Rezende (Montandon, 2004, p. 215).

Às causas desse silêncio documental, que podem abranger todo tipo de conjecturas desde a ocultação proposital com diferentes intuitos, até uma desaparição incidental, 
acrescente-se o silêncio daqueles interessados, direta ou indiretamente, que poderiam ter interferido no curso da história, como o silêncio de Beja.

Os mesmos motivos que teriam levado alguns dos parentes de Dona Beja a se manterem no anonimato, por temor de serem relacionados com uma pessoa de passado tão duvidoso, podem ter movido também os parentes dos outros atores envolvidos na história, o que caracterizaria um calado consentimento para tudo quanto se dissesse. (Montandon, 2004, p. 218)

Pode-se também pensar que esse consentimento resultasse das imagens-lembrança guardadas na memória, aqui vista como fenômeno social, daqueles que, direta ou indiretamente, se relacionaram com os envolvidos na história, e que se encarregaram da sua transmissão. Ou até mesmo porque o que passou a ser lembrado, perpetuando-se na história, de Beja, fosse o verdadeiro.

Enfim, o fato é que Beja foi absolvida. E, por unanimidade. Em seu tempo, por um suposto júri realizado em 4 de dezembro de 1837 (Vasconcelos, 1986). No presente, pelas lembranças daqueles que ficaram, materializando-as, a princípio verbalmente, até que surgisse o primeiro relato escrito, publicado no Correio de Araxá, em 1915.

Não se pode afirmar ser esse o único ponto de vista. Na ausência de documentos que pudessem ser confrontados com os fatos contados ou relatados, muitas são as versões do acontecido, algumas imperativas, outras menos conclusivas, como a que se segue:

O certo é que o ambiente em torno do sobrado amarelo da Beija no Largo da Matriz nunca mais foi o mesmo, e o demônio da dúvida, até hoje, ronda sinistramente a memória de Anna Jacintha de São José.

Teria sido ela a mandante? (Vasconcelos, 1985, p. 128)

Porém, ao que parece, Beja, em seu tempo, não foi vítima de dúvidas quanto à sua inocência. O sobrado (e nele se incluía João) e o Jatobá fortaleciam seus anseios afetivos e profissionais. Com João, terminaria sua vida amorosa. O rompimento se deu algum tempo depois do nascimento de Joana, sem que se saibam precisar os motivos. O que se sabe é que ele morreu no Rio de Janeiro, em 1842.

Beja resolve fechar o Jatobá. Era um projeto antigo, alimentado durante anos como a princípio a única fonte de renda de que dispunha e o local em que alimentava seu prestígio e seu poder, manteve-o mesmo quando já havia acumulado fortuna com outros negócios, como imóveis, gado, e atividades ligadas ao garimpo. 
Ainda por ocasião da Revolução Liberal de $1842^{15}$, teria sido a chácara um dos locais usados pelos rebeldes liberais, causa possivelmente abraçada por Beja, que teria contribuído também financeiramente com 100 mil réis para o movimento (Montandon, 2004).

O tempo passara e, com ele, o tempo do Jatobá, assim como também terminara o tempo de sua vida amorosa. Restavam, a Beja, a família e os amigos sempre presentes nas reuniões do sobrado, além da condução de seus negócios, o que fazia com a satisfação daqueles que foram bem sucedidos.

Por essa ocasião, Joana já se casara com Clementino, mudando-se para Bagagem. O genro tornara-se um bom amigo de Beja. Em suas visitas à vila de Araxá, trazia além de notícias da família, que já se tornara numerosa, as que tratavam dos diamantes. Os achados recentes nos garimpos do rio Bagagem eram as novidades que corriam estradas, levando às suas margens os que ali esperavam fazer riqueza.

Não era exatamente o que Beja procurava, porém animara-se com a perspectiva de mudança. Outro lugar e um outro desafio tentador, o jogo diamantífero como atividade principal, pois como investimento alternativo já conhecia o fascínio de suas regras.

O entusiasmo de Clementino pela expansão da extração de diamantes confirmou-se. Em 1853, encontraram num dos garimpos do rio Bagagem, o diamante "Estrela do Sul"16, fato que certamente pesou na decisão de Beja.

Nada tinha a perder e se estava dividida entre a família - Joana morava em Bagagem e Thereza em Araxá - as mortes de Thereza e Joaquim, ocorrida quase simultaneamente decidiriam por ela.

Os amigos resistiram. Não queriam que Beja partisse. Ficar sem ela significava perder, entre outras coisas, a sua opinião política. "Beja governava homens e, por isso, as autoridades" (Vasconcelos, 1985, p. 348). Sabiam que ao partir levaria consigo muito da história de Araxá e do encanto que emprestara aos costumes da vila. Porém, Beja partiria tão logo resolvesse os assuntos relativos à mudança.

\footnotetext{
${ }^{15}$ Movimento que ocorreu nas capitanias de São Paulo e Minas Gerais, tendo como principal objetivo afastar do governo o gabinete conservador de Dom Pedro II.

${ }_{16}$ Maior diamante encontrado nas Américas e o $5^{\circ} \mathrm{em}$ tamanho no mundo. O Estrela do Sul pesava 254,5 quilates e era perfeito em transparência. Foi comprado pelo Rajá de Boroda, por 2.850 .000 francos (Vasconcelos, 1985).
} 
Vendeu todos os seus bens, que não eram poucos, e embalou seus pertences. Depois de acomodada a mudança em carros de boi e tropa de burros, partiu acompanhada por seus escravos e Clementino, que era o seu guia nessa viagem sem volta.

Na Bagagem, Beja estabeleceu-se na casa que comprara, na Rua da Ladeira, defronte à casa que mandara construir para Joana. As casas eram separadas pelo Rio Bagagem, que cruzava toda a extensão do arraial.

Beja mandou construir no local uma ponte em substituição à precária passagem que antes existia e que foi levada por águas de enchente. Além de financiar a obra, teria acompanhado a construção da "Ponte da Beija", como é até hoje conhecida" ${ }^{17}$

Logo a sua presença se fez sentir no arraial. Diferentemente da forma como se tornara lendária em Araxá, na Bagagem, Beja representava a mulher regenerada, que liderava as ações sociais promovidas pela Igreja, da qual era freqüentadora assídua, respeitada não só pela riqueza, mas por seu caráter empreendedor e participativo.

Para assinalar essa mudança de sua vida, conta-se que Beja pediu à filha que lhe cortasse os longos cabelos, após o que envolveu a cabeça num lenço, sem o qual nunca mais foi vista ${ }^{18}$. Segundo seus descendentes, teria dito que o ato simbolizava a sua retirada do mundo e que, dele, nada mais desejava. Apesar da determinação, não foi o que ocorreu. Pelo menos no que se refere ao seu desempenho como garimpeira.

Afeiçoara-se aos netos e de forma especial a Haydée, de quem era madrinha. Batizaraa em 1856, chamando-a de Haydée Clementina do Amor Divino. Para padrinho, escolhera Augusto Montandon, seu médico e amigo de Araxá.

Coincidentemente, nesse mesmo ano, Beja perdeu a neta mais velha. Theodora Jacintha Fortunata, filha de Thereza e Joaquim, que havia se casado com o irmão de seu pai, o coronel Fortunato José da Silva Botelho. Theodora morreu de parto sem deixar descendentes. Tal fato abalou profundamente a avó, que ainda não se recuperara da dupla perda sofrida pouco tempo antes, a dos pais de Theodora.

Da política local e do império, ela se contentava em ouvir os comentários feitos por seu genro Clementino, descontente com o rumo que D. Pedro II dera ao reino. Ele não

\footnotetext{
${ }^{17}$ Em 1871, Beja entrou com um pedido de ressarcimento à Câmara Municipal de Bagagem da quantia que deliberadamente investiu na construção da ponte, por ser esta "de mais freqüente trânsito", no que foi atendida.

${ }^{18}$ Coube a Mercedes, filha de Joana, guardar os cabelos da avó. Mais tarde, foram queimados por Amaziles, irmã de Mercedes.
} 
poupava a dinastia, responsabilizando também D. João VI, D. Pedro I (que fizera menos que ele) e o fracasso da Regência, o que para Beja em seu exílio voluntário pouco importava.

Bastou que se inteirasse da dinâmica dos garimpos para providenciar a compra das lavras, operação que realizou com o aval de Clementino.

No princípio, foram pequenas lavras, às margens do rio Bagagem, no próprio arraial e em Joaquim Antônio, localidade próxima à Bagagem. Numa propriedade aí situada, conhecida como Paracatuzinho, a extração trouxe maior resultado. Os diamantes encontrados eram comercializados por Beja com capangueiros locais, ou com compradores que vinham das localidades próximas, os quais por sua vez revendiam aos grandes comerciantes do Rio de Janeiro e São Paulo. Conta-se que aí chegavam como diamantes da Beja, o que conferia ao produto melhor preço.

Beja comandava tudo: dos recursos necessários na atividade até a comercialização das pedras. Investiu grande parte de seus recursos e deixou-se contagiar pela atmosfera ilusória que dominava o arraial, que tinha no garimpo a fonte de suas riquezas e de suas misérias.

A sorte estava do lado de Beja, como se vê no trecho de Waldir Costa: "senhora de riqueza considerável, equipou o seu garimpo dos recursos técnicos conhecidos naquele tempo, conseguindo uma produção notável” (Costa, 1950, p. 138).

Tanto foi assim que em pouco tempo construiu uma virada ${ }^{19}$ no rio Bagagem, que ficou famosa tanto pelo alto investimento exigido em sua obra, como pela sua extensão. A Virada da Beja, como ficou conhecida, tinha início nos fundos da sua casa e atingia a entrada do povoado de Bagaginha. A obra exigiu centenas de trabalhadores, muitos deles mantidos, posteriormente, na exploração do garimpo. Beja esperava encontrar nesse seu último empreendimento pedras grandes, talvez do porte do "Estrela do Sul", o que não ocorreu.

A publicidade dada ao empreendimento trouxe visitantes de longe para conhecer a Virada da Beja. Porém, fatores inesperados fizeram com que o esperado sucesso se transformasse em prejuízos constantes. Primeiro uma epidemia que tirou a vida de muitos negros que trabalhavam no garimpo, sem que houvesse recursos médicos para salvá-los. Em seguida, uma outra alteração, essa de mercado.

Numa tentativa de baixar o preço dos diamantes da Bagagem, que pelas suas qualidades atingiam cifras consideradas muito altas e, no caso específico dos diamantes da

\footnotetext{
${ }^{19}$ Mudança do curso da água para colher o cascalho do leito do rio. Fincavam-se madeiras no fundo do leito que eram trançadas de capim, como se fosse uma cerca, que não deixava a água voltar ao curso normal.
} 
Beja, que tinham preços ainda mais elevados, representando uma "grife" no mercado “externo", os compradores das capitanias de São Paulo e Rio de Janeiro passaram a negociar diretamente nas lavras. O procedimento eliminava o atravessador fazendo com que a desvalorização se desse quando o diamante ainda estava na peneira. Em expressão da época significava: “queimar a gema logo na croa” (Rosa, 1999, p. 65).

Na Virada da Beja, a tática surtiu efeitos imediatos. Com uma produção invejável e com uma desvalorização galopante, o garimpo foi perdendo prosperidade. Beja tentou resistir diminuindo a oferta. Guardava grande quantidade de diamantes esperando, com esse estratagema, vender sua produção sem prejuízo. Não conseguiu seu intento e, com o fim da Virada da Beja, terminaria também o sonho de sua dona: tomar para si a "esperança eterna das lavras" (Vasconcelos, 1985, p. 388).

E nesse quadro de desesperança e fadiga para com as coisas da vida, Beja começa a se preparar para deixá-la. Em 1869, fez seu testamento ${ }^{20}$.

Neste, registrou suas últimas vontades expressas no padrão usual utilizado em documentos dessa natureza, o que significa: “(...) as pessoas, além de expressar sua última vontade sobre seu corpo e propriedades, tentavam acertar as contas com os vivos e, principalmente negociar a salvação" (Montandon, 2004, p. 55).

Muito do que possuía já havia sido por ela partilhado. Uma parte entre seus descendentes, outra entre as igrejas da Bagagem e de Araxá, portanto não precisando se preocupar tanto com os bens terrenos e com a justiça dos homens. O testamento revela a preocupação de Beja com o perdão divino.

Conta-se que ao morrer, em 1874, Beja manifestou sua última vontade, beber a água da Fonte da Beja. Clementino mandou buscar. A água foi servida por Severina que, atendendo a vontade de Beja, o fez no mesmo copo de prata que ela usava quando freqüentava o Barreiro.

Purificada, Beja morreu em paz.

\footnotetext{
${ }^{20}$ O testamento de Beja pertence ao acervo da Memória do Judiciário Mineiro, encontrando-se no Tribunal de Justiça de Minas Gerais.
} 


\section{A TRADUÇÃO CULTURAL DE BEJA: história e memória}

O "passado" que vive entre nós, que nos faz falta conhecer, ao qual devemos contas, é um dos elementos do presente e uma das premissas do futuro.

Antonio Gramsci 
Foi como Totinha ${ }^{21}$ que permaneceu na memória familiar, mas nasceu Anna de Souza, no dia 3 de Janeiro de 1890, em Estrela do Sul, Minas Gerais.

Totinha era filha de Haydée ${ }^{22}$ Clementina do Amor Divino, neta e afilhada de Beja e de José Gonçalves de Souza ${ }^{23}$. Totinha era irmã de meu avô, Genésio de Souza (Haydée teve sete filhos: Genésio, Anna, Antenor, Joana, Amazilis, Maria e Alberto).

Criada numa família numerosa, viu-se aos poucos somente em companhia da mãe viúva, após irmãos e irmãs terem-se casado e seguido seus destinos. Foi em Estrela do $\mathrm{Sul}^{24}$ que cresceu, estudou e participou ativamente das obras sociais e religiosas locais, tornando-se conhecedora do legado histórico da cidade, legado esse do qual Beja era parte integrante.

Nesse espaço restrito de Estrela do Sul, acrescentavam-se aos horizontes de Totinha pequenas localidades próximas que não iam além do Triângulo Mineiro, o que, para ela, era o suficiente. Integrava-se perfeitamente nesse universo e não havia necessidade de expandi-lo e nem deixá-lo em busca do que quer que fosse, sendo seus limites o bastante para abrigar suas alegrias e suas tristezas.

A cidade pequena, porém não acanhada, parecia a esse tempo passar por uma pausa, como se, cansada do movimento contínuo a ela impresso pela corrida aos diamantes e satisfeita pelos resultados obtidos, decidisse repousar.

Um ritmo mais lento acompanhava as atividades do garimpo e dos moradores.

$\mathrm{O}$ afluxo de europeus e de migrantes fora, há algum tempo, transferido para Água Suja, localidade situada a quatro léguas adiante, onde se construía uma grande mina aparelhada com moderno maquinário alemão. Em 1903 a construção da mina já empregava mais de 200 trabalhadores braçais, além de mão de obra qualificada, essa representada por profissionais de origem alemã e francesa. A “Água Suja Mining Co.” trazia, com a sua instalação, mudanças de hábitos e costumes para o sertão mineiro, ao mesmo tempo em que levava para o exterior os diamantes encontrados no rio Bagagem.

Entre essas mudanças uma foi representativa na vida de Haydée e sua família: a vinda de um médico alemão, Dr. Max Rudolph ${ }^{25}$, contratado pela mina, e que tempos depois transferiria sua residência para Estrela do Sul. A justificativa para essa transferência

\footnotetext{
${ }^{21}$ Ver anexo 1.

${ }^{22}$ Apesar das diferentes grafias (Haydée, Haidée, Haideé, Haidee), optamos pela primeira que é a usada em família.

${ }^{23}$ Ver anexo 2.

${ }^{24}$ Ver anexo 3.

${ }^{25}$ Ver anexo 4.
} 
voluntária pode ter sido o que nos conta sua esposa, Emmy Rudolph ${ }^{26}$, em seu livro-diário $D a$ minha vida ${ }^{27}$ :

É verdade que em Estrela do Sul o povo é bem mais civilizado, não é tão primitivo. As casas são em sua quase totalidade de barro, mas há as escolinhas, as igrejas... Grande parte da população se compõe de antigas ricas famílias que abandonaram cidades maiores internando-se no sertão com seus escravos, em busca de diamantes. Muitas famílias eram portuguesas e cada uma trazia consigo o que compreendia por civilização e cultura. Havia muitas famílias que, na época da libertação dos escravos, perderam grande parte de sua riqueza que eram justamente esses pobres negros e assim pobres não conseguiram retornar às grandes cidades de onde vieram. O nível cultural dessas pessoas todas correspondia mais ou menos ao nosso, assim que eu me sentia muito bem entre eles. (Parte II, p. 44)

Falava-se do movimento mais lento que reinava em Estrela do Sul.

Do brilho das grandes pedras, os diamantes retirados do leito do rio Bagagem, ficara, para os que continuavam no garimpo, uma eterna promessa: o luzir permanente da camada de mica que cobria as ruas de Estrela e que dava a elas uma luminosidade peculiar. Uma das lembranças reiteradas pelos que lá viveram, como se todas as vias conduzissem a ele, o rio automaticamente se incorporava à paisagem evocada.

O rio "Bagagem" 28 cortava a cidade regulando com suas cheias e vazantes a vida da comunidade. As muitas lendas alimentadas pelas suas águas povoavam o imaginário da população, sendo esse expresso nas histórias contadas vezes sem conta.

Os que tinham o privilégio de morar em suas imediações nunca se esqueceram do seu rumorejar. Mais intenso próximo à ponte central, onde rochas sobrepostas formavam fortes corredeiras, o rio conduzia o olhar e os ouvidos dos passantes.

Haydée e sua família moraram próximo ao "Bagagem", assim como sua mãe Joana morara, e sua avó Beja também. O rio correu como referência espacial e transformou-se em lembrança afetiva para todas elas, as quais o incorporaram em suas memórias, cada uma adequando-o ao seu próprio ritmo.

Totinha colocou o "Bagagem" em sua modesta valise quando meu pai foi buscá-la, em julho de 1950, para uma curta temporada em Araguari, cidade para ela distante, à qual se

\footnotetext{
${ }^{26}$ Ver anexo 5.

${ }^{27}$ Esse diário em um único volume não foi editado e está dividido em duas partes. O original datilografado foi dado à minha mãe Marucha, que durante três décadas se encarregou de emprestá-lo a todos os bagageiros e mineiros de outras paragens que se interessaram pela história do período narrado. O relevante é que nenhum leitor deixou de devolvê-lo. Hoje, o livro-diário Da minha vida, encontra-se em minhas mãos.

${ }^{28}$ Ver anexo 6.
} 
chegava em três horas transcorridas no pó em época de estiagem, ou no barro nas longas temporadas de chuva, pela estreita rodovia que ligava as duas cidades.

Ela não pensou duas vezes ao ser informada da necessidade de sua presença em nossa casa. Minha mãe havia contraído pneumonia e precisava de alguém para cuidar da filha recém nascida. Disponível, por não ter constituído família, e acostumada a atender aos pedidos daqueles que dela precisavam, Totinha era o esteio ambulante do grupo familiar. Ora na casa de um, ora na de outro, o nomadismo doméstico era prática comum em sua vida, o que, para ela, era natural. Não teve dificuldade em arranjar seus pertences para mais uma temporada fora de Estrela do Sul e, sem nenhuma preocupação com a duração de sua ausência, partiu rumo a Araguari.

Iniciou-se, assim, um novo período na vida de Totinha.

Instalada em nossa casa tomou para si a responsabilidade de criar-me. E, foi o que fez. Após o restabelecimento de minha mãe, encontrou pretextos suficientes para permanecer ao meu lado assumindo uma maternidade tardia e inesperada que, hoje, penso ter sido para nós, eu e ela, um desses acasos capazes de transformar nossa existência. Ela juntou-se à vida da família e da "grande" cidade adequando seus hábitos e redirecionando seus afetos. Elegeu Araguari como sua morada e, sobre a cidade, tinha direito adquirido, tanto que não mais voltou para morar em Estrela do Sul, indo à sua terra para visitas rápidas, o suficiente para olhá-la, revendo em seus lugares o passado da cidade que era também o seu. Talvez soubesse que,

(...) a cidade não conta o seu passado, ela o contém como as linhas da mão, escrito nos ângulos das ruas, nas grades das janelas, nos corrimãos das escadas, nas antenas dos pára-raios, nos mastros das bandeiras, cada segmento riscado por arranhões, serradelas, entalhes, esfoladuras. (Calvino, 2003, p. 16).

De lá fez vir seu único legado: uma velha canastra na qual eram guardados, além das guarnições de cama e mesa, herança de sua mãe Haydée, poucos objetos, os quais seriam mantidos como representações simbólicas de um passado distante contando parte da história de seus antepassados. Alguns marcados pelo uso das gerações precedentes, como talheres e travessas em porcelana, os quais lembravam aparelhos de jantar um dia completos e suficientes para as refeições servidas em amplas mesas para famílias, em geral, numerosas; pequenos adereços femininos, como broches e brincos, antes usados por Beja, Joana e Haydée (depois delas, ali ficaram sem uso, a não ser o de conduzir o olhar de Totinha e, a partir daí, o meu, para um outro espaço, o da lembrança); algumas fotos, suportes materiais da memória, mostrando a imagem desbotada de uma ou outra pessoa em pose de "atelier", distanciada e 
fria, como uma do "vovô" Clementino ${ }^{29}$, o marido da "vovó" Joaninha ${ }^{30}$ (e, portanto, genro de Beja), com longas barbas e um olhar penetrante; uma caderneta de couro com a aplicação de um camafeu em porcelana na capa, a qual serviu para prosaicas anotações de compras domésticas realizadas por José Gonçalves, marido de Haydée; um copo de prata, com a respectiva salva (usados por Beja, em sua casa de Araxá); um relógio de parede em forma de “oito” que marcou o tempo de vida de Haydée e Joana na antiga Bagagem.

Não havia entre essas preciosidades documentos de qualquer natureza, nem atestados expressos da realidade individual ou coletiva, nem mesmo cartas ou bilhetes como os que se costuma encontrar, habitualmente, nesses tipos de legados. Mas, no entanto, bastava uma olhada nesses objetos para entender que representavam muito mais do que pequenas trivialidades do cotidiano de Totinha e dos seus.

Pode-se supor que a diversidade apresentada na composição do conteúdo da canastra tenha sido intencional, na medida em que cada porção remetia a uma situação de vida diversa, desvendando, assim, valores e visões de mundo diferentes, modificados e incorporados à cultura de cada pessoa ali representada. Totinha teria assim um esboço de seu passado, o que, para ela, seria confortador.

Pode-se também pensar que ela tenha criado o seu lugar de memória, no dizer de Pierre Nora (apud Rousso, 1996), de forma incidental, recolhendo a esmo pequenas lembranças que ficaram esquecidas por parentes que nas partilhas foram melhor aquinhoados. O fato de ser mulher e solteira, numa família em que todos os irmãos eram casados e com filhos, e, portanto, quantitativamente melhor representados, justificaria essa hipótese.

Mas, qualquer que seja a suposição, ou hipótese, era nos objetos da canastra que Totinha lia e contava oralmente a história ou as muitas histórias que traduziam a sua memória familiar e social, garantindo, assim, a sua permanência.

O que se pode ressaltar a respeito desse acervo pessoal é a sua função: a de possibilitar a reconstrução do contexto, a superfície social, como quer Bourdieu (1996), em que agiram os personagens das histórias narradas pela curadora dessa inusitada coleção.

Regina Abreu (1996) ao tratar dos objetos de dada coleção afirma:

No entender de K. Pomian, uma coleção compõe-se de semióforos, que, diferentes das coisas, dos objetos úteis, são objetos destituídos de valor de uso. Singulares, não servem para serem usados, mas para serem expostos ao olhar. Considerados preciosidades, são dotados de um valor de troca fundamentado no seu significado. Os semióforos são, portanto, pontes entre

\footnotetext{
${ }^{29}$ Ver anexo 7.

${ }^{30}$ Ver anexo 8.
} 
o mundo visível e o mundo invisível, são suportes materiais de idéias; "desempenham a função de intermediários entre os espectadores e o mundo invisível de que falam os mitos, os contos e as histórias" (p. 43).

Dessa maneira, os objetos da canastra permitiam à Totinha evocar o passado contado em histórias que representavam um mundo invisível, o da antiga Bagagem. Nesse mundo ela imprimia a trajetória das pessoas importantes, ou não, de seu tempo e de outros passados, aquelas que a sua capacidade em registrar e arquivar nos escaninhos da memória transformara em personagens inesquecíveis. Ao mesmo tempo, Totinha se colocava como representante do mundo invisível de seus antepassados, os quais se materializariam nos ditos objetos, conferindo-lhes credibilidade através de uma narrativa típica de uma pessoa de poucas letras mas, no entanto, dotada de muitos recursos na arte de fazer reviver o que passou.

Para Walter Benjamin, (1985) "a experiência que passa de pessoa a pessoa é a fonte a que recorreram todos os narradores" (p. 198). Entre esses existe aquele que viaja e tem algo para contar e que trazendo o conhecimento de lugares desconhecidos e distantes, desperta a imaginação e o interesse dos ouvintes. Há também o narrador que de sua terra não se ausentou, como no caso de Totinha: "Mas não é com menos prazer que se ouve aquele que, vivendo honestamente do seu trabalho, ficou em casa e conhece as histórias e tradições de sua terra" (p. 199).

Assim, vieram com Totinha e a canastra a história da Bagagem, que já se chamava Estrela do $\mathrm{Sul}^{31}$, assim como de muitos de seus moradores, inclusive a de Beja.

Como se viu, ao deixar Estrela do Sul em 1950, Totinha, uma senhora idosa para os padrões da época, não se preocupou com a duração de sua permanência em Araguari. É possível que diante da situação apresentada a ela não coubessem considerações dessa natureza, ou, por outro lado, ela nem cogitasse naquele momento que a sua partida seria definitiva. Passado algum tempo, a vinda da canastra simbolizou o caráter de sua permanência em nossa casa: quatorze anos, até sua morte repentina em julho de 1964.

Nesse sentido, quando desceu do carro de meu pai a pequena valise de Totinha não serviria para confirmação de uma possível estada definitiva por ela em nossa casa. Totinha era modesta e possuía poucos pertences. Não usava nenhum adereço em seu figurino a não ser os quatro enormes grampos de tartaruga com os quais prendia o seu coque de trança grisalha, na

\footnotetext{
${ }^{31}$ Inicialmente, em 1722, o povoado foi denominado Bagagem Diamantina, compondo-se por volta de 1849 de dois conglomerados: Cachoeira, que se tornou sede, e Joaquim Antônio que veio a ser Distrito de Santa Rita da Estrela. Em 1852 (Lei 575), o curato passa a ser Distrito de Paz, denominado Nossa Senhora Mãe dos Homens da Bagagem, tendo em 1856 (Lei 777) recebido a autonomia municipal, com a elevação de Bagagem à Vila, condição mudada pela Lei 1101 de 1861 que elevou a Vila da Bagagem à categoria de cidade, passando essa, em 1901 (Lei 319), a ser denominada de Estrela do Sul.
} 
altura da nuca. Nem perfumes, nem quaisquer outros elementos denunciadores de algum traço de vaidade.

Mais tarde ela me confirmaria, com uma de suas histórias, a sua maneira de ser simples e despojada.

Tratava-se de certa mulher que aparecera em sua cidade. Era tida como demente por seus hábitos estranhos. Na verdade era a sífilis a causadora de seus distúrbios comportamentais. Emmy Rudolph imprime realidade a essa personagem quando relata a dificuldade em se obter um novo medicamento para o tratamento da sífilis, o "606", e o crescimento do número de casos registrados em Estrela do Sul:

A primeira a receber o tratamento com o 606 foi a maluca da Maria Chiquinha que tinha os pés cheios de feridas. Os moços se divertiram bastante arrastando a coitada à toda força para dentro do consultório. E a maluca soltava suas piadas, ela não era perigosa, ainda bem. Só às vezes ela se exaltava e a loucura então se tornava um pouco difícil. (Parte II, p. 95)

Aparecera como tantos outros que vinham não se sabe de onde em busca de trabalho nos garimpos e, desesperançados, por ali ficavam em permanente miséria.

Totinha me contou que Maria Chiquinha foi vista, certa vez, sobre uma pedra às margens do rio Bagagem. Trocou o vestido que trazia no corpo por um novo que acabara de ganhar logo atirando o velho na corredeira do rio. Quando lhe perguntaram por que fizera isso, explicou: "sou uma só e não preciso de dois".

Com esse "exemplo fabuloso" justificou para mim o seu restrito guarda-roupa, imprimindo à sua narrativa certa graça. É possível que soubesse, como Jean de La Fontaine (2004), da necessidade de se criar um quadro que represente a descrição de cada um de nós e que, por sua vez, confirma "os conhecimentos hauridos em virtude da experiência pelas pessoas idosas e ensina às crianças o que convém que elas saibam”. (p. 39)

Assim como não tinha vaidade, Totinha também não guardara da juventude, porque não os tinha e não se preocupou em fabricá-los, traços de beleza, nem no que diz respeito às suas feições, assim como nem na sua silhueta um tanto avantajada para a sua estatura mediana.

Mas, é fato que possuía outros atributos que faziam dela uma pessoa especial.

A liberdade era um deles. Devia-a à sua maneira de ser, a qual como se viu, era simples. Não possuía independência financeira. Porém, não a substituíra por uma dependência econômica expressa, derivada de necessidades supérfluas, o que implicaria a ela deixar de ser livre. Essa liberdade exteriorizava-se na autoridade de seu comportamento, o que lhe permitia, 
entre outras coisas, fumar seu charuto de forma prazerosa sem nenhuma preocupação com os resultados de tal feito. Também se refletia na firmeza com que Totinha conduzia suas decisões, fossem elas no âmbito doméstico ou político.

A propósito do hábito de fumar charutos, herdara-o de sua mãe Haydée, fato narrado por Emmy Rudolph na descrição que dela fez em seu livro-diário:

Entre minha querida vizinha Dona Haydée e eu nasceu uma amizade que duraria a vida inteira. (...) Essa vizinha gostava de mencionar que todos os dias tomava um "Barro Alto" e fumava um charuto. Ficara viúva há um ano atraz [1904], tinha seis filhos mas não era pobre. (Parte II, p. 6)

Totinha herdara também de Haydée o dom de escutar. Haydée o tinha. Na sua infância ouvira as histórias contadas por sua avó Beja.

Como se viu, ao chegar à Bagagem Beja estabeleceu-se na casa que comprara, na Rua da Ladeira, defronte à casa que mandara construir para Joana, sua filha e mãe de Haydée. Tanto a proximidade entre as casas separadas apenas pelo rio, quanto a afeição especial com que Beja distinguia sua neta Haydée, de quem era também madrinha, permitiram a essa partilhar das lembranças de Beja.

Para Beja era chegado o "tempo de lembrar". O fato de ter deixado para trás, em Araxá, o seu passado não significou para ela esquecê-lo. Ali estava Haydée, com quem desenvolvera um vínculo de afeto e confiança, pronta para ouvi-la. Bastava sentar-se nas muitas tardes, agora vazias, e deixar que o rumorejar das corredeiras do Rio Bagagem conduzisse a sua memória para o que lembrar e para o como lembrar.

Foi nesse período de inatividade que Beja, longe de suas vidas, a de Araxá e a da Chácara do Jatobá, pôde, no entanto, examiná-las, traduzindo-as conforme a situação presente.

"A menor alteração do ambiente atinge a qualidade íntima da memória" como diz Ecléa Bosi (2004, p. 55) ao tratar da teoria psicossocial de Maurice Halbwacs. Nesse sentido, pode-se intuir que, ao reconstruir seu passado, Beja o tenha sujeitado ao "processo de 'desfiguração' que o passado sofre ao ser remanejado pelas idéias e pelos ideais presentes do velho".(p. 63) E nos ideais de Beja incluíam-se a necessidade de estreitar os laços familiares antes difusos e a de fortalecer a sua nova imagem: a de mulher respeitável disposta a viver, daí em diante, uma vida exemplar.

Muito do que hoje se conhece da vida de Beja deve-se, certamente, às tardes vazias da Bagagem em que avó e neta se entretinham em contar e ouvir. Uma contava o que lembrava e a outra se encarregava de guardar na memória o que ouvia. 
Assim, seria Haydée que mais tarde faria suas as lembranças de Beja, construindo, a partir delas, a sua versão da história da avó. Dessa forma, difundiu-se uma história de vida, a de Beja, ora com acréscimos, ora com omissões, conforme os padrões e os valores daqueles que dela, posteriormente se apropriaram, como Totinha.

É sabido que no tempo de Totinha, pouco restara do arraial da Bagagem da época de Beja e Haydée. Porém, a tradição oral se encarregara de conferir veracidade à história de Beja, a qual continuaria viva na memória de seus descendentes e na da cidade, por eles a terem incorporado na história de seu passado. Nela Beja é representada como personagem ilustre. Evocada com a mesma importância dada ao período em que os diamantes fizeram do Arraial da Bagagem um dos mais prósperos da região, a Beja do Araxá perde espaço para a mulher regenerada e devotada à família que, perdoada de seus pecados, conquistou a estima e admiração dos bagageiros.

Assim, ao ser incorporada à memória da cidade Beja teve suas culpas atenuadas. Se ela previu, ao se sujeitar a um processo de regeneração experimentado na Bagagem, obter além do perdão divino o da sociedade, pode-se dizer que foi bem sucedida: foi perdoada.

Com o perdão, veio a gradativa mudança operada no contexto familiar, nas idéias e valores presentes nesse, no que diz respeito à memória de sua ancestral: fatos, antes omitidos, foram acrescentados à sua história. Não todos, mas os que tal perdão permitia. Descendentes que não se manifestavam até então sobre o tema Beja, sentiram-se anistiados e apresentaram suas versões, como tia Zita, irmã de Totinha, quando foi entrevistada pelo Correio de Araxá em 1965: "apesar de ter seus pecados tinha uma personalidade marcante e inteligência acima do comum, a ponto de mudar o curso da história, pese sua condição de analfabeta" (p. 6).

Para Totinha, que fora ouvinte de Haydée, o perdão oficial dado à memória de Beja, em sua dimensão pública, parece não ter acrescentado nada à história que dela contava. Como boa memorialista, tratara de confrontar os fatos que lhe foram apresentados pela mãe com outras versões do acontecido que chegavam, ocasionalmente, a Estrela do Sul. Nesse exercício Totinha mesclava o saber que vinha de longe, com o saber do passado, o que, por sua vez, aprendera com Haydée. Era na prática desses saberes que Totinha buscava entender a época e o meio em que Beja vivera, numa tentativa de explicar a sua trajetória.

Para tanto não contava com nenhum método ou técnica amparados pelo conhecimento histórico ou científico, já que não os conhecia. Era apoiada em sua intuição, a qual influenciava na criação e transformação de seu objeto, a vida de Beja, o que se dava no momento em que a contava para um ou outro ouvinte interessado em ouvi-la. E, Totinha 
sempre tinha ouvintes. A eles se dedicava entregando-se à arte de narrar com a familiaridade própria dos que souberam ouvir.

Como disse Benjamin (1985) a propósito dos dons de ouvir e de narrar:

Contar histórias sempre foi a arte de contá-las de novo, e ela se perde quando as histórias não são mais conservadas. Ela se perde porque ninguém mais fia ou tece enquanto ouve a história. Quanto mais o ouvinte se esquece de si mesmo, mais profundamente se grava nele o que é ouvido. Quando o ritmo do trabalho se apodera dele, ele escuta as histórias de tal maneira que adquire espontaneamente o dom de narrá-las. E assim se teceu a rede em que está guardado o dom narrativo. E assim essa rede se desfaz hoje por todos os lados, depois de ter sido tecida, há milênios, em torno das mais antigas formas de trabalho manual. (p. 205)

Era em torno da mesa da sala de jantar que Haydée e suas filhas se sentariam à tarde, para as sessões de costura e bordado, as quais se estendiam tarde a fora. Na calmaria que se decretava após as lides domésticas, mãe e filhas, entretidas com a agulha, se entregavam a contar e a ouvir. Passado e presente se impunham nas muitas histórias que se tornavam exemplares, dependendo do seu tema e teor dramático.

Mais uma vez Emmy Rudolph pontua, através da sua narrativa escrita, as muitas memórias que aqui se cruzam, quando lembra do trabalho manual feito por sua amiga Haydée na cozinha ou na sala: "Nas horas vagas eu aprendia com minha boa vizinha a fazer o pão, pão-doce, roscas, etc. (Parte II, p. 5) Sobre minha cama eu encontrei dois maravilhosos e macios travesseiros, cobertos por fronhas ricamente bordadas" (Parte II, p. 36), nesse caso referindo-se a uma surpresa que a amiga lhe fizera ao voltar de longa viagem à Alemanha.

Houve um tempo que a mesa ficou vazia. Joana, Amazilis e Maria se casaram mudando-se para suas respectivas casas. Dessa maneira, a Totinha foi dado mais tempo de ouvir, até a morte de Haydée, fato que a privilegiou em sua arte de narrar.

Mudara o cenário. A mesa de Haydée foi substituída por outras em salas alheias, em torno das quais se cosia, bordava, contava e ouvia. Um costume que, vê-se, Totinha não abandonara nem mesmo quando veio para nossa casa em Araguari.

Nessa cidade moravam também conosco meu avô Genésio, irmão de Totinha, e minha avó $\mathrm{Nica}^{32}$. Pela manhã, sentavam-se na varanda. Ele, ocupado com a leitura de algum romance enquanto Nica e Totinha cosiam e bordavam, o que, por sua vez, não atrapalhava o curso das lembranças dessa última sempre voltadas para o passado vivido na Bagagem. As imagens evocadas nem sempre eram concordantes, mas tinham em comum o fio condutor: a

\footnotetext{
${ }^{32}$ Ver anexo 9.
} 
sua história social tecida com os mesmos quadros de referência cultural e familiar, sendo esses criados a partir de um dado tipo de sociedade.

Totinha, Genésio e Nica tiveram nesse reencontro tardio a possibilidade de confrontar suas lembranças traduzindo-as nas muitas narrativas compartilhadas. Ouvidos atentos não lhes faltavam entre os adultos e as crianças que participavam do seu cotidiano em nossa casa e que, mais tarde, se encarregaram de incorporar suas histórias à memória familiar.

Às histórias dos dois irmãos somaram-se, pelas diferenças, as de Nica. Única mulher numa família de dez irmãos, tivera o privilégio de estudar em colégio de freiras francesas na capital mineira, Belo Horizonte. Essa experiência acrescentou tonalidades distintas ao panorama provinciano das lembranças da velha Bagagem. Dessas lembranças, Nica expulsara Beja. Talvez, por ser a mais religiosa dos três memorialistas. Outra hipótese a ser considerada seria a de que ao entrar, através do casamento, para a família de Beja, não tivesse se adaptado à convivência com a imagem dessa ancestral de seu marido, notória por sua vida pouco recomendável.

Para Nica, nada haveria na história de Beja que justificasse a sua lembrança. Nem mesmo a seduziu a possibilidade de reconstrução da figura de Beja conforme as condições da vida presente modificada por novas idéias e valores, as quais, como já se viu, permitiram a Beja circular em suas múltiplas interpretações entre os seus descendentes.

De qualquer modo, Nica preferiu manter Beja numa distância confortável e foi respeitada em sua vontade.

Totinha passou a contar a história de Beja em caráter reservado, isso depois de resolvidas as dificuldades de espaço (a sala foi substituída pelo quarto de costura, o mesmo onde se encontrava sua canastra) e de tempo (que se restringiu ao que ela se dedicava à máquina de costura).

Como sua companhia permanente, tornei-me a ouvinte eleita para escutá-la contar a sua história predileta. Preocupada com a atenção de um público tão restrito, tratou de ensinarme a bordar para que pudéssemos compactuar da mesma atmosfera, propícia ao contar e ao ouvir.

Assim, em capítulos que se estenderam até a minha ida para o internato em São Paulo, com onze anos, a história de Beja povoou a minha imaginação. Esperava com ansiedade o momento em que Totinha e eu nos dedicávamos a ela, num permanente retocar de pormenores que as reprises permitiam, e no avanço gradativo da narrativa que, terminada, conduzia-nos a passagens que se transformavam em novas histórias, sendo essas fundadas nos muitos enigmas que cercaram a vida de Beja. 
A memória e a imaginação foram combinadas nessa narrativa criativa, o que ocorrera conforme as intenções de sua autora. Ao contá-la, Totinha singularizou sua personagem. Definiu-a em seus aspectos mais marcantes, de acordo com ela, ressaltados em situações que lhe pareceram decisivas para explicar suas atitudes, muitas vezes contrárias aos valores de ordem religiosa, moral e político-social, tão caros à narradora. Para tanto, cortes e omissões foram praticados por ela, ou mantidos conforme as versões da tradição oral, na seleção feita com a finalidade de compor a sua interpretação da vida de Beja, como se verá nas particularidades expostas a seguir.

\section{ANNA JACINTHA SEGUNDO TOTINHA}

Neste período, a narrativa parte da chegada de Beja a São Domingos de Araxá ${ }^{33}-$ GO, por volta de 1805. Beja veio acompanhada por sua mãe, por seu avô e pelo escravo Moisés, procedentes de Formiga - MG.

O deslocamento de uma família em direção a lugares mais prósperos ocorria com freqüência, acontecendo, principalmente, a aquelas que viviam dos poucos recursos proporcionados pela posse de pequenas propriedades rurais, como no caso da família de Beja, e que não gozavam da situação estável e garantida próprias dos grandes proprietários de terras.

A ausência do pai de Beja, entre os que chegaram a São Domingos de Araxá, não foi justificada por Totinha. O peso dado à figura marcante do avô, preenchia-a sem maiores problemas. Homem digno e forte, tomou as rédeas da condução da família, tendo como meta o cumprimento das leis divinas e das leis dos homens. O seu carinho pela neta dominou o quadro afetivo da menina não deixando espaço para a presença materna. Desbotada pela sua condição de mãe solteira, Maria Alves de São José desaparece da narrativa, ao morrer prematuramente.

$$
* * *
$$

A partir da leitura "linear e plana" feita por Rosa Maria Spinoso de Montandon (2004) “das informações extraídas dos documentos oficiais" (neste caso, o "Mappa da População

\footnotetext{
${ }^{33}$ Ver anexo 10.
} 
deste Distrito da Villa Viçosa d'Sam Domingos do Arachá”; 1832, Sessão Colonial, caixa 13, Arquivo Público Mineiro, Belo Horizonte, MG), a mãe de Beja, em tal arrolamento denominada Maria Bernarda dos Santos, não teve o mesmo destino que o presente na narrativa de Totinha:

Como chefe de família, papel que desempenhava como mulher só, descasada e mãe solteira, no censo provincial de 1832, Anna Jacintha foi relacionada oficialmente como branca, solteira, de 32 anos e dona de oito escravos. E, junto com ela, sua mãe, Maria Bernarda dos Santos, também branca, de 56 anos. (p. 42)

Dada a evidência histórica, resta indagar se o desaparecimento de Maria Alves de São José ou Maria Bernarda dos Santos (conforme o documento oficial), na narrativa de Totinha, foi intencional, no sentido de imprimir maior carga dramática à versão mantida pela tradição oral. Ou ainda, se o perfil que dela se traçou, baseado no pouco que se ouviu dizer, faria da mãe de Beja uma presença necessária na trama dos acontecimentos que singularizaram a vida de Beja.

Finalmente, caso se utilize um esforço interpretativo apoiado na historiografia, outra hipótese poderia ser levantada, como o fez Montandon (2004).

Tal hipótese resultaria da "dispersão populacional e a ocupação de novas áreas após o declínio da mineração em Minas Gerais” (p. 36), da pobreza que atingia a maior parte da população da capitania; da situação específica das mulheres abandonadas, viúvas ou mães solteiras, muitas delas tendo na prostituição o único recurso para sobreviver, enfim mulheres que também se juntavam aos que buscavam melhores possibilidades em outras paragens.

Diante desse quadro, Montandon conjectura que Beja e sua mãe poderiam ter vindo entre tantos forasteiros que chegavam a São Domingos de Araxá, na esperança de encontrar uma vida melhor.

Nesse caso desfaz-se a imagem do grupo doméstico, apresentado na versão de Totinha. Originado na persistência com que foi mantido pela tradição oral, mesmo que reduzido, esse grupo representou a base em que se assentou para Beja uma infância regulada pelos padrões morais e sociais estabelecidos, condição necessária a sua inclusão na sociedade de São Domingos de Araxá, à qual se soma a presença do escravo Moisés, símbolo de certo "status" sócio - econômico para a família.

Portanto, a ausência da figura exemplar representada pelo avô, mudaria o caráter da personagem Beja. Não se pode esquecer que foi a atuação do avô, como chefe da família, que definiu o modelo de papel feminino que a neta deveria representar, de acordo com os padrões 
locais, porém acrescido de peculiaridades, como a autonomia e a possibilidade de pensar por si mesma, tão caras à identidade de Beja.

No episódio escolhido como ponto de partida para a narrativa de Totinha, resta apontar a possível presença no grupo familiar de um irmão de Beja, não mencionado por Totinha, que em interpretações posteriores substituiu a figura do avô.

Da sua existência não restam dúvidas. Francisco Antônio Rodrigues foi mencionado por Beja em seu testamento ${ }^{34}$, no trecho que abaixo transcrevo:

Nomeio e péço que sejão meos testamenteiros; em primeiro lugar meo genro Clementino Martins Borges; em segundo lugar meo neto Doutor Francisco Francisco [sic] Ribeiro da Silva, e em terceiro lugar meo Irmão Francisco Antonio Rodrigues; a cada um dos quàes habilito para si e insolidum [?] ad'ministrar os bens respectivos; e ao que aceitar este incargo, deixo de premio cem mil reis; e o tempo de um anno para prestação de comtas em juiso.

Não se sabe se veio com a família ou se nasceu em São Domingos de Araxá, ou, ainda, se ficou em Formiga em companhia do pai, um comerciante local. Diz-se também que Francisco Antônio Rodrigues teria acompanhado a irmã quando essa foi para Bagagem, estabelecendo-se em Barro Branco, onde, na ocasião, foram encontrados diamantes famosos (Rosa, 1999).

Definido o grupo doméstico e o ponto de partida para a narrativa, Totinha dirige sua memória e imaginação para Beja.

Para ela reservou a beleza e a inteligência, predicados necessários ao papel destinado a Beja na trama a ser desenvolvida. A narradora absorveu todos os detalhes necessários a sua representação, sem deixar escapar nem a lenda nem a realidade. Apresentou Beja segundo a ideologia visual de seu tempo, na qual a figura feminina é marcada por uma imagem idealizada, a que contribuem diversos atributos. Entre eles, a beleza física e um rosto meigo que revela em sua expressão a pureza (possíveis indícios de uma forma estética capaz de dar uma impressão viva da memória de Beja, em sua dimensão histórica e mitológica).

Assim se fez Beja: um rosto harmonioso, iluminado por grandes olhos verdes e emoldurado por cabelos castanho-dourados. A essa imagem idealizada, acrescenta-se a inteligência que a caracterizou, fazendo-a superar a pouca educação recebida em seu meio humilde e de poucas letras. ${ }^{35}$ Uma imagem que, descrita pela tradição oral, acompanharia Beja em sua primeira aparição na linguagem escrita: "Reunia todos os encantos de uma beleza

\footnotetext{
${ }^{34}$ Ver anexo 11.

${ }^{35}$ Conforme Capítulo I desta tese.
} 
ideal à esplêndida primavera (...) e no todo harmonioso das linhas e dos contornos, lembrava as formas divinaes (sic) da escrava grega que Paros imortalizou no mármore" (Silva apud Montandon, 2004, p. 149).

Segundo Totinha, o destaque dado à beleza da menina Beja permeia a infância dessa. Aparecia na descrição das suas habilidades na montaria, fato destacado por indicar um traço permanente do caráter de Beja, o de transgressão de normas; na de menina prendada que bordava e fazia rendas; e na de menina fiel aos preceitos da igreja, que freqüentava o catecismo após as missas domingueiras, onde atrairia os olhares dos fiéis e, entre eles, o que de fato lhe interessava, Antônio Sampaio.

A presença de Antônio na narrativa de Totinha imprime um caráter romântico aos acontecimentos, os quais passam a envolver o encantamento despertado por Beja em seu admirador, assim como a insinuação de uma promessa de final feliz.

\section{BEJA E O OUVIDOR SEGUNDO TOTINHA}

A promessa de final feliz, previsível diante dos fatos anteriormente apresentados é, no entanto, desfeita. Beja fora criada para assumir os papéis de esposa e mãe, como todas as mulheres da sociedade colonial, o que se daria conforme o quadro das atitudes e estratégias determinadas por seu avô, que via em Antônio um partido promissor. Não foi o que ocorreu. Beja foi raptada e seu avô morto ao tentar defendê-la. Como vítima é levada para Paracatu do Príncipe, na Capitania de Minas Gerais, onde passa a viver no Palácio da Ouvidoria com o seu raptor, o Ouvidor Joaquim Ignácio Silveira da Mota.

Esse acontecimento decisivo e significativo marca o início da transformação da personagem Beja, a qual assumirá, daí em diante, a condução de seu próprio destino, criando, ao representar o seu novo papel, os elementos necessários à sua figura de heroína.

O Ouvidor passa a integrar a trama central da história contada por Totinha, assim como fora presença obrigatória na trama tecida por sua mãe Haydée, narradora essa que usara em sua urdidura os fios recolhidos da memória de sua avó Beja.

Dessa maneira, nota-se que, nesse momento, o rapto e o Ouvidor definiriam uma situação indicativa do possível desenvolvimento de um enredo melodramático, o que de fato se deu.

Descarta-se de imediato o que seria previsível para moças desonradas nessas circunstâncias, um destino de mulher decaída, para se construir, numa atmosfera que permitiu 
excessos imaginativos de toda sorte, uma configuração da vítima, que aos poucos se metamorfoseou em heroína, imagem com que Beja se fixou no imaginário mineiro.

Para Totinha, a menina tímida e inexpressiva transformara-se em uma dama moldada segundo os costumes da corte, condição tal que lhe permitiu exercitar sua capacidade intelectual no convívio com pessoas influentes que transitavam pelos salões do Ouvidor, em Paracatu do Príncipe.

Dessas e de outras mudanças comportamentais a ela impostas pela sua nova condição, a de cortesã do Ouvidor, Beja tirou as possibilidades de lidar com o seu infortúnio, transformando-o em fonte de poder e realização pessoal.

Em seu relato, Totinha analisava a habilidade com que sua heroína agiu na condução da situação a ela imposta, ressaltando a sua capacidade de lidar com a adversidade, o que, de certa forma, preenchia o espaço destinado a possíveis críticas morais que o fato exigia.

Para completar o quadro francamente favorável à Beja, o retoque final: a participação dela no desfecho da questão territorial mineira, episódio que legitimou sua figura como heroína, à qual não faltaram os traços de força e coragem, tendo esses passado a caracterizá-la justamente a partir dessa atuação memorável.

$$
* * *
$$

Aos olhos de Oliveira Mello, escritor e pesquisador de Paracatu, seria impossível, cronologicamente, que Joaquim Ignácio Silveira da Mota, o Ouvidor e raptor de Beja, tivesse passado por tal localidade. Segundo ele, quando da ocasião do suposto rapto de Beja, o ouvidor que exerceria jurisdição, interinamente, sobre o Noroeste mineiro era o vigário Joaquim de Melo Franco, enquanto Mota estaria vinculado à província goiana. (Rosa, 1997)

Para Oliveira Mello, Beja representa um mito e, como tal, seria capaz de abarcar diferentes significados sociais em determinados momentos históricos nos quais se faria necessária a sua apropriação. O mito, segundo ele, teria sido criado por Sebastião de Afonseca e Silva, responsável pela primeira publicação, em 1915, de um relato histórico sobre Araxá, relato esse onde Beja atuara como heroína principal. Posteriormente, Agripa Vasconcelos dele se apropriou ao escrever A vida em Flor de Dona Bêja, publicado em 1957, retirando Beja do Triângulo Mineiro e transportando-a para paragens muito distantes, as quais Beja, certamente, teria sequer imaginado conhecer. 
Assim, como ficou até aqui assentado pelo que se ouviu de Joana, Haydée e Totinha, descendentes de Beja, pode-se afirmar ser essa uma figura "mitogênica", ${ }^{36}$ tanto em sua representação, quanto em sua história de vida.

Há muita discordância quanto ao local onde Beja e o Ouvidor viveram após o rapto.

Oliveira Mello nega a ida do Ouvidor a Paracatu. Pedro Divino Rosa (1997), também escritor e pesquisador, encontra-o em Goiás Velho:

Pesquisei livros, documentos, papéis diversos e notas sobre a Província, tanto no Museu das Bandeiras, onde são guardadas tais raridades, como no Palácio Conde dos Arcos, onde creio ter morado o Ouvidor em questão, e ainda contei com a laboriosa ajuda do pesquisador Elder Camargos de Passos. Concluí, após checar documentos que provam a existência do ouvidor e de seu poder em Goiás Velho, que fora ele o raptor de Dona Beija e que ali morou a então menina, até a volta da autoridade para Portugal. (p. 87)

Por outro lado, Montandon (2004) diz procurar, em vão, apoio documental sobre o "suposto" rapto de Beja:

(...) não localizamos evidências documentais que o fundamentassem historicamente. (...) Os nomes são reais, mas as circunstâncias que os relacionam são, aparentemente, imaginárias, ou parecem pertencer a outras "histórias" e a outros lugares. Podem ter sido inseridos para preencher as lacunas que existem no período inicial da vida de Anna Jacintha em Araxá e, com eles, compor a seqüência cronológica indispensável a um relato "histórico", segundo era concebido e de acordo com as normas que vigoravam quando foi criado em 1915. (p. 203)

Contudo, Joana, Haydée e Totinha, cada uma a seu modo e em seu tempo, se encarregaram da inclusão do rapto em suas narrativas. O caráter mítico e dramático que reveste o fato permitiu, nessas múltiplas traduções, as interpretações fantasiosas, os acréscimos e as omissões. A credibilidade dessas narradoras, no que se refere ao conhecimento da história contada, assim como a coerência interna apresentada na construção de suas narrativas, teriam concedido a essas um caráter verossímil.

Levando-se adiante tal questão, pode-se considerar que Joana, Haydée e Totinha, como ouvintes e narradoras da história de Beja, experimentaram a dependência que se acredita existir entre aquele que escuta, o contador e o discurso narrativo fundador, o qual, como se viu, partiu de Beja. Ao que parece, todas elas possuíam, em menor ou maior grau, duas das qualidades inerentes ao bom narrador - a da capacidade de memória que as

\footnotetext{
${ }^{36}$ Peter Burke (2000) considera mitogênicas as figuras que, por sua singularidade, são mais susceptíveis de se tornarem mitos.
} 
aproximou do que ouviram contar e a da imaginação que as levou aos descaminhos criativos as quais, por sua vez, as fez personalizar, cada uma a seu modo, a história de vida de Beja.

Pode-se ainda incluir o depoimento de Maria da Ressurreição Borges Caixeta, neta de Clementino e Joana, bisneta de Beja, tal como o transcreveu Pedro Divino Rosa (1997) em seu livro Dona Beija:

Dona Beija, afirma a bisneta, fora realmente raptada por um ouvidor da Corte, que encantou-se por ela e ao voltar para a sua Ouvidoria mandou os soldados buscá-la para ele. Relatou que o avô de sua bisavó fora morto pelos homens da autoridade, na tentativa frustrada de resgatá-la e que a jovem vivera com o amante até completar 18 ou 19 anos, quando retornou para o povoado, onde morou até mudar para a Bagagem.(p. 95)

Seja como for, o rapto de Beja está entre os fatos escolhidos para compor a sua história de vida contada oralmente tanto por sua própria protagonista, quanto pelos seus descendentes, sendo tal acontecimento mais tarde, ainda confirmado quando da passagem dessa história de vida da forma oral para a escrita, não sendo mesmo dispensado em outras versões como a literária, a teatral e a televisiva. Em meio a muitas hipóteses, menciono uma que pode ser significativa. O historiador Waldemar de Almeida Barbosa encontrou nos autos de um processo por rapto indícios que justificariam uma possível aproximação desse rapto com o rapto de Beja.

Nesse sentido, se caracterizaria como a "apropriação" de um fato ocorrido
em Serro, antiga Vila do Príncipe, em Minas Gerais. Segundo a
documentação, em 1801 , nesse lugar, um ouvidor de nome Antônio Seabra
da Mota foi acusado de raptar a filha de um comerciante português, a quem
devia dinheiro. O rapto teria como objetivo forçar a realização de um
casamento, através do qual sua dívida ficaria saldada. No entanto, o pai da
jovem moveu contra o raptor um processo de indenização, cujos autos
constam nos arquivos. (Barbosa apud Montandon, 2004, p. 204)

Note-se que os documentos aludem a 1801, quando Beja tinha um ano.

A justificativa para a apropriação do fato narrado acima por narrativas da história de Beja baseia-se, no caso, não apenas na semelhança dos sobrenomes dos ouvidores, Seabra da Mota e Silveira da Mota, como também na semelhança dos nomes dos locais onde aconteceram as histórias, Vila do Príncipe e Paracatu do Príncipe.

Todas essas apropriações, mencionadas ou não, abrem espaço, entre o conhecido e o desconhecido, para inúmeras indagações que, respondidas ao longo do tempo, ainda comportam acréscimos e atribuições de novos significados. 
No caso da história contada por Totinha, Beja foi raptada pelo Ouvidor, acrescentando-se ao fato, todas as circunstâncias que dele decorreram.

Quanto ao Ouvidor, personagem real na trama contada, como atestam documentos judiciários resultantes de sua atuação em São Domingos de Araxá, os quais seriam datados do início do século XIX, viu-se que ele não foi julgado pelos seus crimes: o de rapto perpetrado por ele contra Beja e o de ser responsável pela morte do avô dela. Voltou à Corte e posteriormente a Portugal, falecendo com mais de 80 anos. ${ }^{37}$

Totinha se indignava com essa impunidade e encontrava na questão das terras antes mineiras, indevidamente tomadas pela Capitania de Goiás, o único recurso capaz de justificála. Ao promover a reintegração das terras do Sertão do Novo Sul, hoje Triângulo Mineiro, incluindo São Domingos de Araxá onde se deram os crimes, à Província de Minas Gerais, o que foi feito, segundo Totinha, por insistência de Beja, o Ouvidor teria eliminado a possibilidade de ser punido, pois o caso, nesses termos, passava para a jurisdição da comarca de Paracatu, ficando sujeito, portanto, à sua Ouvidoria.

Nessa versão, percebe-se que não foram apenas as circunstâncias provocadas pelo rapto que motivaram o empenho do Ouvidor em resolver a questão territorial. A interferência de Beja foi ressaltada por Totinha pela firmeza com que ela atuara sobre o amante, conduzindo-o nos atos necessários ao retorno do Triângulo Mineiro à Província de Minas Gerais.

Para Totinha que tinha Minas Gerais como seu país, Beja era uma heroína. Ouvi-la narrar esse capítulo da vida de sua admirada heroína representava estar em meio a um campo de batalha, no qual, entre fogo e sangue, Beja irrompia gloriosa ao devolver aos mineiros as suas terras de há muito perdidas.

Na versão menos apaixonada de Haideezita Braga Jacob, sobrinha de Totinha, que residiu em Araxá, a atuação de Beja assim ficou: “(...) Haideezita admite que a ancestral havia sido mesmo cortesã e que usou a sua beleza e encantamento para atingir seus objetivos e influenciar um ouvidor da Corte para desmembrar o território triangulino da província de Goiás." (Rosa, 1997, p. 81)

Apesar das considerações feitas por Oliveira Mello no artigo intitulado Dona Beja, Paracatu e o Triângulo, publicado no Estado de Minas, na década de 1980, as quais afirmariam ser uma "farsa gritante" a participação de Beja no episódio que levou o "Triângulo de volta até os mineiros" (Montandon, 2004), foi como se ouviu Totinha contar: Beja deixou o círculo da vida privada para se fixar como figura política na história de Minas Gerais.

\footnotetext{
${ }^{37}$ Conforme Capítulo I desta tese.
} 
Totinha não leu o relato do Correio de Araxá, assim como não se interessou pelo romance de Agripa Vasconcelos, A Vida em Flor de Dona Bêja, apesar da rapidez com que ele, ao sair do prelo, chegou à nossa casa em Araguari. Por insistência expressa de minha mãe Marucha, admiradora incondicional da Beja, sua tetravó, o livro veio pelo reembolso postal e durante semanas circulou pelas mãos e pela imaginação dos que a ele se entregaram. Pode-se imaginar a diversidade de opiniões que surgiram diante dos fatos apresentados por Agripa a leitores que, de há muito, ouviam a história de Beja contada, oralmente, em diferentes contextos e épocas.

Assimilar as relações entre tradição escrita e oral, memória e história ou tradição oral e história, provocou nesses leitores uma inquietação própria daqueles que, ao receber novas idéias e valores, percebem as dificuldades relativas às adaptações necessárias diante do novo contexto: a adoção de caminhos alternativos de interpretação das idéias do autor, desconhecido e invisível. Isto significa repensar a força da subjetividade e da emoção na história criada e recriada por intermédio da memória familiar. Repensar ainda, certa melancolia que os mais próximos, como minha avó, minha mãe e até mesmo Totinha em sua posição de defesa continuada, sentiram ao perceber que Beja as deixava, pelo menos não fazia mais parte da sua intimidade, ao ganhar nova roupagem para trilhar caminhos desconhecidos.

Por que Totinha não teria lido a obra aqui em questão? Afinal, não fazê-lo representava, na época, o mesmo que significa, hoje, desconhecer o enredo da novela apresentada no horário nobre pelo canal da televisão. Porém, ela limitava-se a ouvir as opiniões dos que leram e, como não se manifestava, é possível que refletisse sobre as relações entre escrita e oralidade, preferindo o silêncio a opinar sobre o mundo dos textos que não era o seu, ou pelo menos, não era terreno em que se sentisse à vontade.

Ítalo Calvino (1996) escreveu o seguinte:

Enquanto espero que o mundo não-escrito se torne mais claro, sempre há uma página escrita aberta diante de mim, onde posso voltar a mergulhar: faço-o sem demora e com a maior satisfação, porque ali, pelo menos, mesmo que só compreenda uma pequena parte do todo, posso alimentar a ilusão de que mantenho tudo sob controle. (p. 141)

Diferentemente de Ítalo Calvino com relação ao mundo escrito, Totinha se entendia melhor com o mundo não-escrito e, além do mais, Beja, para ela, já tinha a sua história inscrita nas memórias daqueles que a traduziram, nas muitas vozes que, em diferentes 
timbres, se encarregaram de contá-la, como a que agora escrevo apoiada na que a mesma Totinha me contara.

\section{BEJA E SÃO DOMINGOS DE ARAXÁ SEGUNDO TOTINHA}

Beja e o Ouvidor deixaram Paracatu e seguiram direções opostas: ela rumou para São Domingos de Araxá, ele para a Corte.

Para ela, a separação era, há muito, esperada. Tanto é verdade que nos últimos tempos vividos em Paracatu do Príncipe, Beja preocupou-se de forma metódica e objetiva em amealhar recursos suficientes que lhe garantissem vida confortável, na qual não faltasse o requinte a que se habituara nos dois anos que aí passara. Acredita-se que ela assim agira por saber da solidão e do vazio que aguardavam uma mulher, como ela, sem bens. ${ }^{38}$

Uma tropa de burros e vários carros de bois carregaram os pertences de Beja em sua viagem de volta, feita em companhia de seus quatro escravos, inclusive Severina. Totinha se esmerava na descrição minuciosa dessa bagagem. Detalhava cores, texturas e formas das jóias, adereços e vestidos que entulhavam as canastras, não se esquecendo dos móveis, porcelanas, cristais, objetos de adorno e outros apetrechos domésticos, cuidadosamente embalados e acomodados nos carros de bois. Invariavelmente terminava o inventário de tão preciosos bens (que, desenhados por ela em pormenores, deixavam-se ver por inteiro tal qual os objetos que guardava na canastra) contrapondo-os à infelicidade de sua proprietária. Beja os ganhara, mas perdera a possibilidade de ser feliz.

Era essa mulher infeliz que Totinha acompanhava em seu percurso de volta. Como se fosse um "batedor" (explorador do campo), seguia, às vezes, adiante da caravana para antecipar os obstáculos e dificuldades que a viajante teria de vencer para chegar a seu destino, o qual nada teria de promissor segundo ela. Buscava em Paracatu e nas lembranças lá deixadas por Beja, tanto o motivo esclarecedor da transformação na índole de sua personagem quanto nas suas atitudes e ações, enfim, o motivo do que ela faria em São Domingos de Araxá. Nesse vaivém, Totinha buscava referências que justificassem o que teria de contar sobre a vida de Beja, isso por ser sabedora de que, nessa história, não mais caberia o recurso "foram felizes para sempre", muitas vezes por ela utilizado em outras tantas histórias que me contava.

\footnotetext{
${ }^{38}$ Conforme Capítulo I desta tese.
} 
Mas, se o final feliz foi dispensado diante dos acontecimentos que marcaram os muitos anos de reinado de Beja em São Domingos de Araxá, nem por isso Totinha interrompeu sua narrativa. Pelo contrário, utilizou, intencionalmente ou não, seus recursos de narradora ao imprimir na narrativa ritmos diferenciados: rápidos para as passagens indesejáveis, tornandoas quase imperceptíveis; e lentos para as ações que escolhia como exemplares, pelo seu conteúdo adaptável aos modos e costumes vigentes, ou, por outro lado, pela sua mensagem, capaz de configurar os bons propósitos de Beja.

Vê-se assim que a mudança de caráter de sua personagem exigiu também de Totinha mudanças no seu modo de contar, ou ainda, no seu método de montagem da história de Beja, no qual, como se verá, os cortes não foram dispensados na seleção por ela feita.

Limitar-me-ei aos aspectos marcantes dessa história para Totinha, mesmo porque parte deles compõe o enredo da "biografia possível" de Anna Jacintha de São José, tema do capítulo anterior.

Faço, no entanto, um intervalo. Tentei em vão evitá-lo, pois minha idéia inicial era apresentar a história de Beja, segundo Totinha, de um só fôlego, recobrando, dessa maneira, o ponto de partida para as demais interpretações que surgiram, fazendo da protagonista uma figura estelar na história de Minas Gerais. Pensei que pudesse resgatá-la da memória como a Beja que, de tantas vezes presente no cotidiano familiar, tornara-se íntima e real como sujeito histórico e com um trajeto de vida verdadeiro. Não foi o que ocorreu.

Além das dúvidas presentes em minha memória, a cada avanço na pesquisa (na qual Beja não é mais uma pessoa íntima, mas objeto a ser pesquisado), tanto na sua vida, como na transposição dela para a produção televisiva, irrompiam novas fontes que ora validavam, ora contradiziam a versão de Totinha.

Nesse sentido, foi preciso ordenar as muitas vozes numa tentativa de compreender as transformações, as adaptações e as possíveis deturpações nas muitas interpretações da vida de Beja.

Eis então São Domingos de Araxá.

De São Domingos de Araxá, Totinha registrou os cenários onde Beja atuara: o sobrado da Praça da Matriz, a Chácara do Jatobá e o Barreiro, esse com suas fontes de águas radioativas. Após instalar Beja nesse espaço restrito e dar a ela uma posição social distinta tanto das mulheres de família, como das mulheres prostituídas, Totinha acompanhou-a em suas aventuras amorosas. Nesse percurso, acrescentou às imagens da vítima, da sedutora, da heroína, todas já anteriormente incorporadas à sua personagem, a da mulher virtuosa. 
Involuntariamente transformada em cortesã, Beja teria sido vítima das circunstâncias do seu rapto ainda quando menina e da conseqüente rejeição social em São Domingos de Araxá. ${ }^{39}$

Das aventuras, Totinha manteve a singularidade com que Beja escolhia os seus parceiros (ao atirar no alvo uma flor vermelha, durante o trajeto diário para o Barreiro), além do caráter estritamente comercial dessas relações fugazes.

Dos grandes amores vividos por Beja entre o sobrado da Praça da Matriz, sua residência oficial, e a Chácara do Jatobá, reservada para receber seus admiradores, em festas e saraus que acabaram por lhe garantir sucesso econômico e social, Totinha registrou Antônio Sampaio e o Dr. João Carneiro de Mendonça.

Antônio, como se viu, foi o primeiro amor de Beja, sendo interrompido quando ela foi raptada pelo Ouvidor. O reencontro marcado pela amargura de não poderem realizar seus sonhos juvenis, ele por estar casado com Anna Felizarda de Rezende e ela por não representar mais o ideal de esposa por ele pretendido, resultou num longo romance no qual à ilusão de felicidade, mesclavam-se desentendimentos constantes, desentendimentos essas que teriam trazido problemas para a vida profissional de Beja e para a família de Antônio.

Segundo Totinha, Antônio e Beja tiveram uma filha, à qual deram o nome de Thereza Thomazia de Jesus, sendo essa criada pela mãe, já que o pai, por ser casado, não pôde assumila nem em seu registro de nascimento, nem publicamente. Também, segundo ela, Beja resolveu, após perceber que não poderia ser feliz com Antônio, não recebê-lo mais em sua casa, o que o teria levado ao desespero. Foi assim que Antônio incumbiu dois escravos de surpreender Beja, numa manhã em que se dirigia ao Barreiro, para espancá-la brutalmente, o que quase a matou.

A tragédia só haveria chegado ao fim, algum tempo depois, com o misterioso assassinato de Antônio, crime que não teria sido esclarecido.

Totinha não deixou de mencionar a possibilidade de Beja ter sido a mandante do crime, suposição até hoje não descartada. Em sua narrativa, o julgamento do escravo alforriado que alegou ao ser preso ter sido contratado por Beja para executar Antônio, foi descrito de forma a atestar a inocência de Beja, a qual tudo negou. Além da sua palavra e a dos muitos amigos, pessoas influentes na sociedade local, contribuiu para o desfecho favorável a ela a falta de indícios ou de provas de acusação feita pelo assassino, também absolvido, por ter ficado comprovado que teria matado em legítima defesa, após o que nunca mais foi visto. ${ }^{40}$

\footnotetext{
${ }^{39}$ Conforme Capítulo I desta tese.

${ }^{40}$ Conforme Capítulo I desta tese.
} 
Quanto ao Dr. João, parece ter sido ele a grande paixão de Beja. Para Totinha, que deu a ele lugar de destaque em sua narrativa, o fato de Beja e João terem se apaixonado e vivido uma longa história de amor deveu-se, em parte, às circunstâncias em que se conheceram. Beja já havia dado por terminada a tumultuada experiência amorosa com Antônio, assim como suas aventuras vividas no Jatobá já lhe tinham rendido poder e autonomia suficientes para ocupar um espaço representativo na sociedade local, na qual certa dignidade foi atribuída à sua figura. Encontrava-se, portanto, livre de qualquer incumbência, fosse ela afetiva ou profissional, pronta para dedicar-se ao que lhe pareceu ser um sentimento verdadeiro. Além disso, João era solteiro, jovem, educado e apaixonado o suficiente para entender o caráter independente de Beja, que pôde, assim, exercer sua liberdade, na qual se incluíam suas atividades na Chácara do Jatobá. ${ }^{41}$

Nesse período nasceu a segunda filha de Beja, Joana de Deus de São José, avó de Totinha, segundo ela, filha justamente do Dr. João Carneiro de Mendonça, que continuou a ser recebido no sobrado da Praça da Matriz, compartilhando a sua vida com Beja e Joana.

Totinha não sabia o que motivou o rompimento do casal. Ora mencionava a recusa de Beja em aceitá-lo como marido, ora a partida de João para o Rio de Janeiro onde morreu pouco tempo depois. O que sabia e que afirmava com certeza era que, com João, Beja encerrara sua vida amorosa.

A vida de Beja, a partir daí, caminhou sem ímpetos ou emoções extraordinárias.

Thereza já estava casada com Joaquim, irmão do Coronel Fortunato José da Silva Botelho, homem de projeção política e econômica na Vila de Araxá, e levara ao casar um dote considerável, digno das exigências de tão ilustre família.

Beja já tinha netos. Era rica, poderosa e, já então, havia conseguido diversificar seus negócios, o que lhe permitiu encerrar as atividades da Chácara do Jatobá e dedicar-se aos muitos amigos (Totinha não lhes deu nome) que freqüentavam as reuniões do sobrado.

Nessa atmosfera desprovida de histórias para serem contadas, Totinha registrou o casamento de Joana com Clementino, que a teria levado a mudar para Bagagem onde ele vivia, e as mortes de Thereza e Joaquim, em 1852, que precipitaram a decisão de Beja em deixar Araxá e mudar-se para Bagagem, onde iniciaria uma vida nova.

$$
* * *
$$

\footnotetext{
${ }^{41}$ Conforme Capítulo I desta tese.
} 
O sobrado construído por Beja em São Domingos de Araxá parece ser o mesmo reconstruído por Totinha. Para essa obra de elevado custo Beja, segundo Totinha, teria usado parte dos recursos que recebera do Ouvidor. No sobrado iniciara sua vida de cortesã, sendo essa posteriormente transferida para a Chácara do Jatobá, distinguindo-se, a partir de então, a residência onde morou e criou suas filhas do cenário reservado aos seus propósitos comerciais.

Totinha afirmava, baseada no que sua mãe Haydée lhe contara, que a fortuna atribuída a Beja e que possibilitara as aquisições de bens imóveis e a vida luxuosa levada em São Domingos de Araxá, embora tenha tido sua origem no que Beja recebera do Ouvidor, foi por ela aumentada. E aumentada, em muito, graças ao numeroso círculo de admiradores por ela recebidos na Chácara do Jatobá, muitos deles vindos de longe na esperança de desfrutarem dos seus conhecidos dotes de cortesã irresistível.

Thomas Leonardos (1986) escreveu, ampliando a idéia apresentada de forma sucinta pelas palavras de Totinha, a propósito do negócio de Dona Beija, em Dona Beija - A feiticeira do Araxá, livro no qual se baseou a adaptação feita da vida de Beja para a forma de telenovela:

O negócio era o seguinte: a chácara do Jatobá era uma casa de diversão (...) mas uma diversão regrada, disciplinada.

Um porteiro musculoso, imponente em sua libré impecável comandava uma equipe de escravos e fâmulos de confiança. Tinha carta branca para selecionar os senhores fazendeiros que quisessem repousar e divertir-se na Chácara do Jatobá.

Das condições preliminares eram:

que não residissem no Araxá, nem em suas redondezas;

que solicitassem, com uma antecedência mínima de dois dias, autorização para serem recebidos no Jatobá;

que viessem bem trajados;

que fossem brancos (pois a senhora tinha preconceitos racistas);

que pagassem à vista e à entrada, a taxa fixa de duzentos mil-réis.

Isso dava direito:

a penetrar na chácara desde as dez horas da manhã;

a usar todas as dependências do vasto solar, menos aposentos particulares reservados a Dona Beija;

a participar com ela de um almoço às dez e trinta, onde as melhores iguarias e as mais finas bebidas lhes eram servidas;

às doze, repouso e sesta;

às treze horas, Dona Beija reapareceria e os convidados decidiriam, por maioria o que preferiam; jogos de salão, violão com canções ou simples conversa com Dona Beija;

às três da tarde, era servido um lanche ligeiro, acompanhado de orquestra, para os que quisessem dançar com Dona Beija;

às quatro e meia encerrava-se a festa e os convidados se retiravam. (p. 95) 
Guardados os possíveis excessos de Leonardos, o quadro permite avaliar a determinação com que Beja administrava o seu empreendimento, tornando-o um sucesso financeiro. O mesmo era confirmado por Totinha em sua narrativa sem, contudo, o tom imaginativo da linguagem de Leonardos.

Para completar as normas organizativas de seu negócio, ainda conforme Leonardos, Beja poderia convidar um dentre os presentes para permanecer em sua companhia, o que era feito de acordo com seus critérios, de modo que "ninguém teria o direito de reclamar fosse o que fosse, nem mesmo a escorchadora taxa de entrada significava obrigação alguma por parte dela". (Leonardos, 1986, p. 95)

Ao criar essa atmosfera de expectativa, Beja conseguia manter uma clientela fixa, a qual, por sua vez, se encarregava de divulgar os prazeres de simplesmente estar no Jatobá e a ilusão sempre renovada de poder, um dia, ser o escolhido de Beja para, em caráter privado, permanecer em sua companhia.

O prêmio final, e sobretudo a incerteza de ganhá-lo, davam ao ambiente do Jatobá uma moldura excitante de jogo de azar, que obrigavam o eleito feliz a retornar, e o que ainda não fora contemplado a voltar também, esperançado por um olhar que supunha mais terno, um aperto de mão que imaginara mais demorado, ou mesmo a esperança de uma palavra mais significativa. (Leonardos, 1986, p. 96)

Apesar de existirem outras hipóteses para a "suposta" fortuna de Beja, como a que registro a seguir, Totinha acabou por ter a sua história traduzida por Leonardos e outros autores que se ocuparam do assunto, variando apenas o grau de fantasia apresentado nos relatos desses.

Montandon (2004), ao buscar na historiografia indícios que apontassem para as possíveis atividades realizadas por Beja, considera:

a arquitetura de seu sobrado, com cinco portas no térreo, sua localização num local nobre da praça, ao lado da Igreja Matriz de São Domingos, e o nome de Anna Jacintha encabeçando uma relação de 31 moradores, dos quais 9 eram mulheres, estabelecidos no município e registrados em 1834 com "negócios", nos autorizam a considerar o comércio varejista como uma de suas possíveis atividades. (p. 39)

Segundo a autora, pode ser validada a hipótese, como constatou Luciano Figueiredo (1997), em Mulheres nas Minas Gerais, da presença das mulheres no comando do comércio varejista em vendas e pequenos estabelecimentos, isso até o fim da colônia. Além disso, Figueiredo diz ainda que, paralelamente a essa atividade comercial, outras, como o 
contrabando e a prostituição, eram comumente praticadas por suas proprietárias. Tal o motivo de Montandon (2004) pensar na prostituição como provável atividade não só de Beja como também de sua mãe, Maria Bernarda, finalizando: "De acordo com a historiografia desse período, há um longo histórico de prostituição familiar na tradição colonial mineira” (p. 40).

Para Totinha, que ao justificar a procedência dos bens de Beja parecia não ter dúvidas, ela soube administrar o seu "negócio". Independente do ponto de vista da lei ou da Igreja (Totinha era católica praticante), Beja estava previamente perdoada. Não fora ela que escolhera o mau caminho. Tentara, ao voltar para São Domingos de Araxá, retomar a condição de moça decente e casadoura, esperando, para tanto, amparo das circunstâncias do destino que a vitimara, somando a essa possibilidade o fato de ter sido graças à sua intervenção que o Triângulo Mineiro voltou a ser incorporado a Minas Gerais. Tal não ocorreu. Beja tornou-se alvo de toda sorte de intolerância e incompreensão do povo, o que provocou, por sua vez, a mudança de seu caráter e de seus propósitos.

A respeito do sobrado e da Chácara do Jatobá, imóveis que pertenceram a Beja, e antes de se apresentar o que deles a história comprovou, foi necessário pensar nos recursos que tornaram possível, por parte da compradora, essas aquisições.

Do sobrado $^{42}$ sabe-se que Beja o construiu e nele morou até sua partida para Bagagem, vendendo-o posteriormente, conforme Escritura de compra-venda de 25 de julho de 1864 (Livro $\mathrm{n}^{\circ} 1$, folha 48v. Cartório do $2^{\circ}$ Ofício de Notas. Araxá, MG.). Também se encontra documentada a aquisição feita por ela de outras casas vizinhas ao sobrado. ${ }^{43}$

É relevante notar que tal construção não é o mesmo sobrado onde hoje funciona o “Museu Histórico de Araxá Dona Beja”, inaugurado em 1965, por ocasião do Centenário de Araxá, tido como o "sobrado de Beija”. Este, por ter pertencido às irmãs Herculana Cândida e Cândida Antônia de São José, ambas com o mesmo sobrenome de Beja, e estar situado no mesmo quarteirão que o dela, o das irmãs São José na esquina e o de Anna Jacintha de São José no meio, passou a ser chamado pelo povo de "sobrado de Beija", o qual foi autenticado pelas escrituras e mantido por Assis Chateaubriand, quando este o comprou para instalar a aludida instituição (Montandon, 2004).

Sobre o museu, diga-se que ele cumpriu a função do seu idealizador, Chateaubriand, ao funcionar como um dos instrumentos de construção da representação da "Beja heroína", celebrando-a e imortalizando-a. Ali se exibe o que pode engrandecê-la, não importando, no

\footnotetext{
${ }^{42}$ Ver anexo 12.

${ }^{43}$ Escritura de compra-venda, de 26 de janeiro de 1832, que se encontra no Arquivo do Museu Dona. Beja, em Araxá-MG.
} 
caso, a comprovação da procedência dos objetos que supostamente teriam a ela pertencido, tema ainda hoje discutido entre seus descendentes. Depois do ingresso no museu, esses objetos, réplicas ou não dos originais, tornaram-se evocativos, servindo para a legitimação da ilustre personagem, e mesmo salvando-a, talvez, de um possível esquecimento.

Beja viu-se assim assentada no sobrado da esquina que, após reformado, ${ }^{44}$ passou a abrigar a sua memória, mesmo que nele não se possa sentir o perfume das Pastilhas do Serralho que, como contava Totinha, ela tinha por hábito mandar queimar antes da chegada das visitas.

A poucos passos encontra-se, desfigurado pela ação do tempo e pelo esquecimento coletivo, o sobrado que, de fato, Beja construíra na Praça da Matriz, o mesmo que a persistência da memória de Joana, de Haydée e de Totinha colocou em seu devido lugar.

Da Chácara do Jatobá existem apenas menções documentais, ora aparecendo ele como um "retiro de Dona Anna Jacintha de São José" (como nos autos do processo referente aos acusados de participação na Revolução de 1842), ora como "retiro da Beija" localizado na sesmaria do Barreiro, ou, ainda, como "Chácara da Beija" localizada no Jatobá (de acordo com escrituras de compra e venda registradas nos cartórios de Araxá, a partir de 1874, sem que Beja nelas apareça como parte diretamente interessada). Num desses documentos, no qual a propriedade herdada por Joaquim Eulálio Vieira de Souza e sua mulher, Maria Paula Rodrigues Tavares, de Joaquim Gregório Rodrigues Tavares, pai e sogro dos beneficiados, é por eles vendida, pode-se encontrar uma descrição sucinta do que teria sido a "Chácara da Beija”: “(...) formada por um sobrado, equipada com monjolo, cercada por mil e duzentas braças de "vallas", e situada nas "cabeceiras do Córrego do Retiro", logo, bem próxima de Araxá. A casa foi demolida o que deve ter ocorrido após 1889, já que consta autorização para tal fim, em documento de permuta da casa da chácara por outra na cidade realizada por seus proprietários (Sancho de Freitas Mourão e Ana Augusta Montandon Mourão). (Montandon, 2004)

Ainda a respeito da Chácara do Jatobá, resta notar a alusão a ela como "Retiro de Dona Anna Jacintha", citação tal que estaria presente em um depoimento no processo da Revolução de 1842.

Esse depoimento foi feito por um dos acusados de liderar o movimento, aliado e aparentado com os Botelho, logo, com Joaquim Ribeiro da Silva Botelho, genro de Dona Beja, motivo pelo qual dificilmente poderia ter-se enganado a respeito do nome de sua proprietária.(Montandon, 2004, p. 227)

\footnotetext{
${ }^{44} \mathrm{O}$ sobrado foi reformado por uma empresa estatal.
} 
Dos cenários registrados por Totinha, além do sobrado e do Jatobá, acrescentam-se o Barreiro (onde Beja repunha suas energias nos banhos diários na Fonte que hoje traz o seu nome) e a sua presença nas missas domingueiras.

Nesses cenários públicos, Beja, ora montada em seu cavalo, quando se dirigia ao Barreiro, ora a pé, quando se dirigia à igreja, seguida de suas escravas adornadas de forma a compor um quadro inesquecível, deixou gravada imagens particularmente lendárias, sendo essas grandes responsáveis pelas representações dela feitas com a intenção de retratá-la.

Quando Totinha me apresentou Beja, o que fez valendo-se da sua memória e imaginação, para ela reservou, entre outros predicados, a beleza traduzida num rosto harmonioso, iluminado por grandes olhos verdes e emoldurado por cabelos castanhos dourados, imagem que permaneceu em sua primeira aparição na linguagem escrita.

No entanto, considerando-se que, no caso da imagem de Beja, muitos foram os relatos orais posteriormente registrados pela linguagem escrita e iconográfica, é preciso ressaltar, com base em Portelli, a fluidez e a inconstância como característica das fontes orais. Assim, partindo do universo familiar, embora Joana, Haydée e Totinha em suas narrativas apresentassem Beja da mesma forma, a cada vez que o faziam revelavam um novo retrato, já que "recordar e contar já é interpretar" (Portelli, 1996, p. 60). Isto pode ser estendido às demais representações da imagem de Beja.

Ecléa Bosi (1994), ao tratar das lembranças de família, escreveu: "Se cada família não tem mais como na Roma antiga, seus cantos, preces, seu próprio culto, não se pode negar que tenha um espírito seu, uma maneira de ser, lembranças e segredos que não passam das paredes domésticas" (p. 424).

Bem pode ter sido esse o motivo pelo qual Totinha não me contou que Thereza Tomazia de Jesus, a primeira filha de Beja, nascida em 15 de fevereiro de 1819, não era filha de Antonio e sim do padre Francisco José da Silva, fato comprovado por documentos cartorários. Num dos documentos, uma escritura de perfilhamento, datada de 16 de maio de 1831 e registrada no Cartório do $1^{\circ}$ Ofício de Notas de Araxá, o padre Francisco reconheceu a filha e legitimou sua paternidade.

Além desse documento, por ocasião da morte de seu pai, padre Francisco, Thereza aparece como herdeira legitimada e sendo favorecida no testamento dele. Também sua mãe, Beja, foi beneficiada, recebendo uma soma considerável em dinheiro pelos bons serviços a ele prestados, conforme se pode conferir no inventário do Pe. Francisco José da Silva, realizado em 1845 e arquivado na caixa no. 43 do Arquivo do Fórum Tito Fulgêncio, em Araxá-MG. (Montandon, 2004) 
Às evidências apontadas acrescenta-se a observação feita por Eni de Mesquita Samara (1989), a propósito do assunto, tendo em vista a freqüência com que o fato ocorria no período colonial:

São freqüentes, nessa época, as referências à conduta irregular por parte do clero e os testamentos são especialmente ricos pelas alusões que fazem às relações desse tipo. A existência reconhecida de filhos naturais, frutos dessas uniões, também são comuns. Estando enfermo, em 1860, um sacerdote declarava, em testamento, que "por fragilidade humana tenho dois filhos menores (...), os quais neste meu solene testamento, reconheço e declaro por meus legítimos herdeiros". (p. 128)

Dessa maneira, guardadas as distâncias de tempo e espaço, o testamento acima citado, realizado em São Paulo em 1860, e o do padre Francisco, originário de Araxá e datado de 1845, apresentam disposições semelhantes por observarem os direitos das sucessões relativas aos filhos dos testadores, os quais, por serem espúrios, como atestam as expressões "por fragilidade humana" (em São Paulo), ou "por fragilidade da carne" (em Araxá), dependiam da existência do testamento para serem legitimados e, assim, beneficiados: "Quanto aos espúrios, na inexistência de testamento, a sucessão era permitida somente na falta de descendentes e caso houvesse consentimento expresso de reconhecimento por parte dos ascendentes ainda vivos" (Samara, 1989, p. 156).

Foi assim que Thereza pôde receber seu quinhão, mesmo sendo filha de clérigo e de mãe prostituta, portanto, sujeita às limitações colocadas pela legislação colonial para casos como esse, isso no que se refere ao Direito das Sucessões.

Do padre Francisco, sabe-se ter sido ele:

(...) figura polêmica que a julgar pela documentação disponível, esteve sempre envolvido em disputas políticas locais, além de atividades escusas que lhe valeram uma série de denúncias. Isso sem falar nas relações "sacrílegas" mantidas, "por fragilidade da carne", não só com Anna Jacintha, mas também com outras mulheres. Além de Thereza, tais relações renderamlhe, pelo menos, outros dois filhos, Pedro Amado de São Paulo e Placidina Maria de Jesus, também reconhecidos em cartório. (Montandon, 2004, p. 47)

Além dessas informações, sabe-se, também, que o padre Francisco pertencia a uma das famílias mais ilustres de São Domingos de Araxá. Era filho do tenente Gregório José da Silva e de Dona Thereza Thomazia de Jesus e primo-irmão de José da Silva Botelho, fazendeiro bem sucedido e amigo incondicional de Beja, à qual se encarregara de oferecer proteção: "Os homens de José, escravos fortes e capatazes, se encarregavam de dar segurança à mulher e a sua chácara”. (Rosa, 1999, p. 41) 
Acompanhando a intrincada relação que se estabeleceu entre a família do padre e a de Beja, José da Silva Botelho, primo do padre e amigo de Beja, era pai de Joaquim Ribeiro da Silva Botelho, que se casou com Thereza, filha de Beja e do padre Francisco.

Também era filho de José o coronel Fortunato José da Silva Botelho, o qual se casou com Theodora, neta de Beja, filha de Thereza e Joaquim. Por ocasião da morte de sua neta Theodora, Beja moveu um processo judicial de reclamação de herança contra o coronel Fortunato, fato do qual, ainda se falará.

Nos documentos já mencionados - a escritura de perfilhamento e o testamento do padre Francisco José da Silva - encontra-se comprovada a participação de Beja e sua filha Thereza Thomazia nessa trama familiar, na qual os casamentos revelam as estratégias de acumulação e transmissão de riquezas utilizadas pela família Botelho, atitude bastante comum entre famílias do período colonial que, como a aqui apresentada, pertenciam às camadas abastadas da elite rural brasileira, exercendo, assim, expressivo controle sobre a vida política e econômica local.

Além de ser um dos maiores latifundiários de São Domingos de Araxá, o coronel Fortunato era o líder do grupo político "da Mandioca", assim chamado por se reunir na fazenda da Mandioca, da qual ele era o proprietário. ${ }^{45}$

Como disse Eni de Mesquita Samara (1989): “(...) a Igreja, o Estado e as Instituições econômicas e sociais eram afetadas e até muitas vezes controladas pela influência de certas famílias ao nível local”. (p. 17) Ao que se acrescenta que o prestígio da família Botelho, em São Domingos de Araxá, pode ter concorrido para evitar a desaprovação social que poderia ter afetado Thereza, assim como pode ter sido um dos mecanismos utilizados por Beja para se fortalecer social e economicamente.

Cabe lembrar em relação ao fato de Thereza ser filha do padre que:

O processo de adequação dos ilegítimos parece ter sido quase natural, ficando bem evidenciada a falta de preconceito no caso dos filhos de padres, tão comuns na sociedade brasileira. Enquanto uns disfarçavam seus rebentos sob o título de "afilhados", outros criavam-nos às claras, em sua companhia, recebendo (sic), muitas vezes, cuidadosa educação e bens que lhes permitiam uma melhor integração na sociedade colonial. (Samara, 1989, p. 63)

No caso de Thereza Thomazia de Jesus, nascida em 15 de fevereiro de 1819, filha "natural" de Beja, seu pai, o padre Francisco, não foi seu padrinho, como se pode verificar em

\footnotetext{
${ }^{45}$ O nome "Grupo da Mandioca" derivou da denominação da sesmaria herdada por Joaquim e Fortunato de seu pai, José da Silva Botelho, local onde os rebeldes liberais se reuniam. Fortunato era o chefe desse partido e queria que a região se tornasse um território independente (Rosa, 1999).
} 
seu registro de batismo: "De acordo com o registo de batismo, foram padrinhos da menina o quartel-mestre Jerônimo José da Silva e Dona Thereza Thomazia de Jesus, mãe do padre batizante, Francisco José da Silva.” (Montandon, 2004, p. 37)

Portanto, Thereza era afilhada de sua avó paterna, com igual nome.

Dada a importância social do batismo que seria determinada pela função do compadrio na sociedade colonial, função essa que revela que ter "um padrinho importante e influente era uma forma de se colocar socialmente, ser bem-aceito e recebido na casa para fazer visitas" (Samara, 1989, p. 75), pode-se imaginar as intenções do padre Francisco e Beja ao garantirem a convivência da filha com a família Botelho, a qual era, também, a família do padre. Além do mais, pode-se dizer que tal relação de compadrio ainda demonstraria a cumplicidade dessa família em relação ao fato.

Sabe-se que Beja e o padre tiveram um longo relacionamento, embora ligações como essa fossem, na maioria das vezes, efêmeras. Acompanhando a trajetória dos dois amantes através dos indícios deixados em documentos e em relatos amparados na tradição oral alheios ao âmbito familiar (incluindo-se aí Joana, Haydée e Totinha, a qual dessa história nada preservou), a relevância de tal ligação pode ser observada.

Thereza nasceu na fazenda do padre, onde Beja permaneceu durante o período do resguardo. Esse fato seria confirmado por ela mesma, em 1864, nos autos do processo de reclamação de herança que moveu contra o coronel Fortunato, documentação aqui comentada por Montandon (2004):

De sua parte Anna Jacintha não negava nada. "Confessava", sim, ser mãe solteira, reconhecendo ter sido Thereza "filha espúria e sacrílega de danado e punível coito". Mas, entre os vinte e dois itens em que sustenta sua argumentação, confirmava nunca ter ocultado sua gravidez, fato "publico e notório", comprovado pelo nascimento de sua filha na Fazenda do Campo Aberto, propriedade do vigário onde ela teria "Recebido sem exceção, todas as pessoas que então a procuravam para visitá-la e a nenhuma ocultou a verdadeira causa que a retinha reclusa e de cama durante a necessaria dieta (sic)". (p. 73)

Na sequiência, evidencia-se, em 1826, o estreitamento das relações de Beja com a família do pai de Thereza, através do registro de batismo de Antônio, filho de Thomé Francisco da Silva Botelho, parente do padre, no qual Beja aparece como madrinha, posição que ocupará outras vezes, como em 1836, perante outras pessoas ligadas direta ou indiretamente a essa família. (Montandon, 2004)

Após o nascimento da filha, Beja continuou morando em seu sobrado na Praça da Matriz, enquanto o padre em sua própria casa, vizinha a dela. 
Em 1832 ela adquiriu outras casas no mesmo quarteirão, as quais, pela sua localização, possibilitaram um acesso seguro, independente da via pública, entre as duas residências, a sua e a do pai de Thereza. A estratégia servia tanto para facilitar a comunicação entre eles, como também para atender as normas vigentes, de forma a evitar a caracterização de um possível concubinato.

\begin{abstract}
Mantendo-se os amantes em casas separadas, à vista de todos, as relações ficariam desqualificadas como "concubinato qualificado" mantido entre "mulher (...) solteira com clérigo (...) teúda, e manteúda na própria casa", crime passível de punição não só pela Igreja como pela lei civil. (Montandon, 2004, p. 66)
\end{abstract}

Acrescente-se a essas estratégias, a hipótese, não comprovada, de que a privacidade na comunicação entre as casas dos pais de Thereza teria possibilitado ao padre criar a filha em sua companhia, ao ser essa rejeitada pela mãe, conforme foi afirmado pela defesa do coronel Fortunato, no referido processo movido por Beja contra ele: “(...) nem a supplicante pode assim chamar de filha a Dona Theresa, sogra do suplicado, pois que não a tendo criado em sua companhia antes em casa em poder do referido Vigário no caso de exposta, não tem sucessório (...)”. Beja contra-atacou dizendo ter criado e mantido sua filha em sua casa até seu casamento: “(...) criando-a, educando-a, zelando-a, e finalmente casando-a com Joaquim Ribeiro da Silva Botelho, conferindo-lhe por essa ocasião hum dote proporcionado às forças de sua fortuna (sic)". 46

Criada pelo pai ou pela mãe, não se sabe ao certo, Thereza casou-se com o primo do padre. Isso não invalida o significado antes dado a esse casamento por Totinha, ou seja, o da singularidade que marcou a trajetória de vida de Beja, acrescentando, no entanto, uma possibilidade mais prosaica, que é a da utilização do casamento entre Joaquim e Thereza, pelos seus pais, como instrumento de fortalecimento de interesses familiares.

De qualquer forma, sendo ou não válidas as suposições feitas sobre os significados atribuídos ao casamento de Thereza e Joaquim, a filha do casal, Theodora Jacintha Fortunata, neta de Beja, se casaria em 1855 com seu tio, o coronel Fortunato José da Silva Botelho, confirmando ser comum a prática de casamentos consangüíneos na família dos Botelhos, não representando essa, no entanto, uma exceção num contexto em que: "Essas uniões por laços de sangue ou de afinidade estenderam-se por gerações, sendo inúmeros os exemplos encontrados nos testamentos" (Samara, 2004, p. 46).

\footnotetext{
${ }^{46}$ Processo de Reclamação de Herança. (21 de nov. de 1862, folhas 15v-18v-21v.) Arquivo do Fórum Tito Fulgêncio. Araxá-Mg.
} 
Theodora morreu em 1856. Não tinha pais, já falecidos na ocasião, ou filhos, deixando como herdeiros seu tio e marido, o coronel Fortunato, e sua avó Beja. O coronel Fortunato recusou-se a dividir com Beja o total dos bens em questão. Para ele, apenas os bens que compunham o dote que Theodora aportara ao casamento, herança de seus pais, estaria sujeito à partilha, fato que levou Beja a dar início ao processo judicial de reclamação de herança, dele saindo vitoriosa, após longa disputa (mais de seis anos, nos quais o processo percorreu todas as instâncias judiciais terminando na decisão favorável à Beja, dada pelo Tribunal Superior de Apelação no Rio de Janeiro). ${ }^{47}$

Apesar da ausência de Totinha nessa história, a de Beja e do padre, e nas demais que daí derivaram, imagino o prazer com que ela me contaria, se soubesse, a vitória obtida por sua heroína, Beja, na luta travada contra o coronel Fortunato. Certamente, a narradora destacaria da trama central a determinação e a coragem com que Beja enfrentara esse homem poderoso, capaz de estender o seu prestígio aos meios político, jurídico e social de Araxá, o que não impediu Beja de sair vitoriosa, atendidos que foram seus direitos.

São apenas conjeturas. Mas, ao fazê-las tomo a mesma direção dada por Totinha em outras situações, as quais puseram à prova o que Beja, para Totinha, tinha de melhor: a determinação, a coragem e a liberdade com que atuou em sua própria vida.

Assim como também são conjeturas as que faço ao pensar a respeito da ausência de toda essa história na narrativa de Totinha. Teria ela feito esse corte para manter em segredo o que Haydée lhe contara e pedira que assim o fizesse? Ou será que Totinha de fato desconhecia a história, assim como também Haydée que não a ouvira nem de sua mãe Joana, nem de sua avó Beja? Voltando às "lembranças e segredos que não passam das paredes domésticas" com os quais iniciei minhas indagações, que paredes guardaram esse segredo, o da história de Beja com o padre? Em que tempo? No de Beja, no de Joana, no de Haydée, ou no de Totinha?

Viu-se que o fato de Thereza Thomazia de Jesus, nascida em 1819, ser filha do padre era "público e notório" como afirmaria a própria Beja em 1864, tendo para confirmá-lo o nascimento da filha ter-se dado na fazenda do vigário onde, dito também por ela, teria "recebido sem exceção, todas as pessoas que então a procuravam para visitála e a nenhuma ocultou a verdadeira causa que a retinha reclusa e de cama (...)" (Montandon, 2004, p. 106).

\footnotetext{
${ }^{47}$ O processo, em sua íntegra, encontra-se no Arquivo do Fórum Tito Fulgêncio em Araxá-MG.
} 
Pode-se dizer ter sido essa uma "confissão" tardia. Beja já morava na Bagagem. Estava velha, mas não o suficiente para deixar de lutar pelos seus direitos. Para tanto deveria estar preparada para dizer a verdade. E foi o que fez. O que não se sabe é se o que consta nos autos do processo, com trânsito limitado ao território da justiça, circulou entre as paredes domésticas na Bagagem. Ou melhor, caso tenha circulado, de que forma teria se dado a reconstrução desse episódio, parte do passado de Beja, nesse novo contexto, o familiar, onde Beja se situara ao mudar de rumo e de vida?

Acredito que Joana e Clementino conheciam a história em sua forma original.

Joana por ter vivido em São Domingos de Araxá, até casar-se com Clementino e mudar-se para Bagagem. Mesmo considerando que quando Joana nasceu, Thereza já estava casada e morando na fazenda de seu marido (a diferença de idade entre elas era de 19 anos), e que a possível convivência entre elas foi interrompida pela morte de Thereza em 1852 (Joana tinha então 14 anos), não se pode esquecer que, segundo Beja, o fato de ser Thereza filha do padre era "público e notório" pelo menos em São Domingos de Araxá. Também aí foram documentadas as providências legais tomadas pelo padre Francisco, a escritura de perfilhamento e o seu testamento. Indo adiante, é bom lembrar que Joana, nas palavras de Theodora, filha de Thereza, era a "(...) tia a quem tanto amo, se tem havido alguma falta de minha parte a de revela-la, (sic) pois he involuntária”. ${ }^{48}$ Tia e sobrinha registravam em carta seus afetos e saudades e, provavelmente, seus segredos. Parece que em relação aos outros cinco filhos de Thereza (Joaquim, Francisco, Saturnino, José e Antônio) não houve maior aproximação com a tia Joana.

Quanto a Clementino, o qual antes de ser genro e confidente de Beja freqüentara o seu sobrado em São Domingos de Araxá, pode-se afirmar que ele conhecia toda a história. Igualmente aqui se pode ir adiante: Clementino foi o procurador de Beja no processo movido por ela contra o coronel Fortunato, tomando, portanto, conhecimento de suas particularidades.

E no que diz respeito à pequena Haydée? É possível que quando chegou o seu tempo de ouvir, essa história já não fizesse parte dos muitos capítulos em que se dividia a vida de Beja, os quais se sucediam, dia após dia, na longa novela contada a ela por sua avó Beja.

Justamente por isso Totinha teria ouvido Haydée contar que Thereza era filha de Antonio Sampaio. Mesmo que um dia soubesse que não era Antônio o pai de Thereza e sim o padre Francisco, talvez não tivesse mudado o curso da sua narrativa, para Totinha, a verdadeira.

\footnotetext{
${ }^{48}$ Trecho de carta de Theodora para a sua tia Joana. (Processo de Reclamação de Herança. 21 de nov. de 1862. (Arquivo do Fórum Tito Fulgêncio. Araxá-MG).
} 
Na verdade, o fato de Thereza ser filha do padre não invalida a presença de Antônio Sampaio na vida de Beja (como se viu o padre e Beja moravam em casas separadas), nem as muitas histórias sobre esse amor infeliz.

A respeito da história que Beja viveu ao lado do Dr. João Carneiro de Mendonça, pai de Joana (o que foi contado por Totinha), nossa narradora não se distanciou das demais histórias que tiveram tal casal como protagonista, seja pela conotação romântica, seja pela concordância em relação aos fatos narrados.

\section{BEJA E A BAGAGEM SEGUNDO TOTINHA}

Clementino foi o grande incentivador das mudanças na vida da sogra e amiga.

Não fosse o seu entusiasmo pelos diamantes e o encorajamento que levava a Beja em suas visitas freqüentes a Araxá, ela lá se deixaria ficar. Estava desmotivada e não partiria dela qualquer iniciativa para modificar a monotonia em que se transformara seus dias, estando esses limitados, agora, ao sobrado, às práticas religiosas e à manutenção de seus bens.

Foi Clementino que orientou Beja na venda de suas propriedades em Araxá e na compra de sua casa na Bagagem, cuidando para que essa fosse próxima da que ela mandara construir para Joana. Essa proximidade que teria proporcionado a Beja desfrutar do aconchego familiar, sendo tal aconchego traduzido na presença constante de sua neta Haydée, a quem dedicou o afeto reservado em tantos anos de vida mundana.

Além do mais, foi Clementino quem cuidou da aplicação dos recursos de Beja em seu novo empreendimento, o garimpo.

Beja comprou lavras às margens do rio Bagagem. Aprendeu tudo o que precisava para tocar as atividades do garimpo, tanto os recursos necessários à extração das pedras preciosas, quanto os referentes à comercialização delas, deixando-se contagiar mansamente pela ilusão própria daqueles que esperavam a cada dia o aparecimento de um grande diamante.

De início teve sorte, o que a levou a construir uma virada no Rio Bagagem que ficou conhecida como a Virada da Beja, empreendimento de grande porte que, no entanto, não lhe trouxe o sucesso esperado. Além de as pedras encontradas não corresponderem às expectativas de Beja, o preço dos diamantes despencou em virtude de alterações de mercado. Ela resistiu o quanto suas energias e recursos permitiram. Sofreu perdas irreparáveis nas suas economias e na maneira como se deixou abater por esse infortúnio. 
Desaparecia com a Virada da Beja a mulher independente e corajosa que tentara mais uma vez, seduzir o destino, fazendo com que a vida corresse a seu modo.

Assim contou Totinha a qual dizia ter Beja desaparecido nas águas turvas da virada no Rio Bagagem. 


\section{A CONSTRUÇÃO E A TRANSFIGURAÇÃO DA PERSONAGEM}

DONA BEJA: na pintura, no teatro, no romance e no carnaval

Diz Plutarco que os pintores antigos, quando pintavam os reis, se neles houvesse algum defeito que não queriam que passasse despercebido, corrigiam-no na medida do possível, mantendo embora a semelhança. Assim, pois, desejo que em toda história se mantenham modéstia e discrição e que haja um esforço para que não se repitam gestos e poses. 


\section{PINTURA}

Faremos uma breve incursão no tempo entre a morte de Totinha e sua história de Beja e a exibição da telenovela Dona Beija, para melhor conhecermos as representações que de Beja foram feitas nesse período, atualizando, dessa forma, a personagem e sua memória.

Aliás, antes mesmo de ouvirmos a história contada por Totinha, vimos que Beja já se fizera notar, fazendo sua primeira aparição na imprensa, em março de 1915, como protagonista na História de Araxá, publicada na forma de folhetim pelo Correio de Araxá ${ }^{49} \mathrm{O}$ sucesso obtido junto aos leitores do jornal, quer pelo formato da publicação, narrativa seriada, quer pelo seu conteúdo, dramático-histórico, colocou Beja na galeria dos personagens que, por suas características dramáticas, seria, posteriormente, muitas vezes revisitado e apresentado em criações literárias, teatrais e televisivas.

Diferentemente da Beja de Estrela do Sul que se fez tímida e recatada em sua memória privada, não ultrapassando os limites da história oral, a Beja de Araxá manteve a notoriedade resultante dos acontecimentos por ela lá vividos, memória que se tornou pública através da publicação da História de Araxá. Estava pronta para ser resgatada diante de necessidades político-sociais locais, ou mesmo de outras esferas governamentais, que também se utilizaram da imagem de Beja, contribuindo para a sua divulgação além das fronteiras mineiras, como nos conta Montandon (2004):

O Estado Novo e a década de 1940 foram o regime e época em que Dona Beja foi re-descoberta, passando a ser divulgada intensamente pela imprensa, superando as fronteiras regionais e alcançando o resto do país. Iniciavam sua cristalização no imaginário brasileiro, obedecendo aos desígnios oficiais e à nova ordem estabelecida, para cujos planos nacionalistas sua figura e significado foram ajustados. Sua função legitimadora original passou a fazer parte de um projeto maior e de uma estratégia nacional de governo que, entre outras coisas, previa a penetração e uma maior presença do governo federal no interior do país, como estratégia para acelerar a integração nacional. (p. 109)

Fora assim, então, que Beja participou das festividades que marcaram a inauguração do Grande Hotel do Barreiro, em Araxá. Construído por iniciativa do governo do Estado, o hotel contava com a possibilidade da exploração das fontes hidrominerais do Barreiro, além da prática do jogo em seu cassino. ${ }^{50}$

\footnotetext{
${ }^{49}$ Conforme Capítulo I desta tese.

${ }^{50}$ A construção do hotel teve início em 1938 durante o governo de Benedito Valadares e terminou em 1945, quando foi inaugurado.
} 
Hoje, para os que lá vão, Beja se apresenta retratada em técnicas e situações diversas, revelando o potencial artístico que acompanha a sua figura. ${ }^{51}$

A personagem de 1940, agora personificada em formas e cores comuns às técnicas pictóricas utilizadas por Ferreira, mantém a mesma imagem de Beja registrada em nossa memória pela descrição dela feita por Totinha em sua história: "um rosto harmonioso iluminado por grandes olhos verdes e emoldurado por cabelos castanhos - dourados". Tal imagem, por sua vez, inspirou o retrato de Beja descrito por Sebastião de Afonseca e Silva em 1915: "reunia todos os encantos de uma beleza ideal à esplêndida primavera (...)". ${ }^{52}$

Desde o momento em que Beja foi criada a partir da realidade que a memória, privada ou pública, insistiu em recriar nas representações até o momento aqui tratadas e em outras das quais ainda falaremos, parece-nos que o objetivo foi o de fornecer a imagem de uma personagem caracterizada, em seu aspecto físico, antes de tudo pela beleza, naturalmente sujeita aos ditames estéticos do tempo e lugar de seus criadores.

Ao tentarmos atualizar a personagem num determinado espaço de tempo, o compreendido entre a história de Totinha e a da televisão, surgiu a necessidade de estendermos nossa busca ao tempo passado antes de Totinha.

Tal procedimento transformou o que nos parecia uma passagem simples, por seu caráter meramente informativo, no momento oportuno para acompanharmos de perto a construção e reconstrução da personagem Beja, realizadas, como se observou, nas muitas narrativas que serviram de ponto de partida para obras nos mais variados formatos, como os que por ora nos importam: o de pintura, o de teatro, o de romance, o de carnaval e o de televisão.

Lembrando Renata Pallottini (1989),

Em primeiro lugar, é bom que se note: o primeiro meio de apreensão que tem o espectador, a sua primeira forma de atingir essa criatura que é o personagem é a visual. O personagem se mostra, assim, inicialmente, sob o seu aspecto, digamos, físico. Isto não é bastante exato, é claro, mas nada aqui é exato. Basta que se entenda. (p. 64)

É certo que de Beja não restaram imagens como vimos num outro momento. Tratouse, portanto, de sem nenhum suporte material, pinturas ou fotos, construir a personagem Beja. A mesma Beja que nos foi dada a conhecer em seu aspecto externo pela voz de suas

\footnotetext{
${ }^{51}$ Beja aparece em três murais de autoria de Joaquim Rocha Ferreira assim localizados: no interior das Termas; num dos corredores térreos do Grande Hotel e no interior da Fonte Dona Beja.

${ }^{52}$ Conforme Capítulo II desta tese.
} 
narradoras, Joana, Haydée e Totinha, as quais a fizeram bela em seus traços e contornos, registrando-a de forma inesquecível em nossa memória.

É assim também que Beja, em 1915, entra em cena, "figuradamente, através do texto. E, no texto, explícita ou implicitamente, com maior ou menor riqueza de detalhes, o autor tratou de dizer qual é o seu aspecto externo" (Pallottini, 1989, p. 64).

Mantido e confirmado o seu aspecto físico, Beja passou, a partir daí, a despontar em espetáculos e ocasiões diversas nos quais as mudanças se resumiram à gradação dos traços de beleza impostos pelos recursos estéticos, técnicos e de linguagem, específicos da arte narrativa de cada uma das formas em que foi representada.

O certo é que ao surgir bela nas cores dos murais do Grande Hotel do Barreiro, Beja traz, em suas atitudes e nos indícios cenográficos que completam as cenas em sua imobilidade aparente, os elementos de há muito conhecidos através do mito Dona Beja, elementos esses caracterizados na tradição oral e no relato de 1915. E, parece-nos ser a partir dessa idéia, que Joaquim Rocha Ferreira esboçou em traços fabulosos as características físicas, sociais e psicológicas da personagem. Em nenhuma outra ocasião, Beja fora lembrada com tantos detalhes como nessa redescoberta feita pelo batismo da imagem.

É justamente no universo do estudo iconográfico, no caso o das representações feitas de Beja através das pinturas de Ferreira, que damos continuidade ao trabalho de pesquisa voltada para a interpretação da personagem Beja, com o objetivo de entender a sua construção nos papéis que ela viria a desempenhar no romance, no teatro, na alegoria carnavalesca e na televisão.

Assim, pensamos complementar o trajeto até aqui realizado, no qual as traduções culturais feitas de Beja e de sua história de vida foram analisadas de forma multidisciplinar, para a qual concorreram outros referenciais históricos e documentais, como relatos (orais e escritos) e memórias.

Antes de tratarmos dos murais e das imagens neles traduzidas por Ferreira, ouçamos o que nos diz Leon Battista Alberti (1989) sobre a pintura:

(...) achei que devia mostrar aqui como a pintura não é indigna de que lhe consagremos todo nosso trabalho e dedicação. Contém em si a pintura tanto quanto se diz da amizade - a força divina de fazer presentes os ausentes; mais ainda, de fazer dos mortos, depois de muitos séculos, seres quase vivos, reconhecidos com grande prazer e admiração para com os artífices. Diz Plutarco que Cassandro, um dos generais de Alexandre, tremeu com todo o corpo ao ver a imagem de seu rei. (...) Assim a fisionomia de quem já está morto vive pela pintura longa vida. (p. 95) 
Por tudo isso, o reconhecimento da Beja, agora um ser quase vivo, revelaria de modo singular a dúvida sobre a sua identidade, sobre a sua unidade e a sua permanência fora do porto seguro da memória dos seus familiares e de Sebastião de Afonseca e Silva, que dela resolveu se ocupar descrevendo-a nas páginas que deram origem ao folhetim ${ }^{53}$ publicado pelo Correio de Araxá.

Podemos, então, entrar no Grande Hotel do Barreiro, em Araxá, certos de que nossa observação estará dirigida apenas para o que diz respeito à construção da personagem Beja. Pensar, no entanto, como os outros teriam visto os murais de Ferreira no seu tempo, não é nosso propósito.

Comecemos pelo mural ${ }^{54}$ que se encontra no interior das termas.

Uma legenda antecipa a imagem: “1800. A fama e a beleza de D. Beja venciam as distâncias e traziam para Araxá admiradores residentes nas mais afastadas regiões do país. $1890 "$.

No que diz respeito às legendas que acompanham pinturas, lembremos de E. H. Gombrich (1986) que assim se colocou: “(...) é a legenda que determina a verdade da pintura". Acrescenta em seguida que, embora os termos "verdadeiro" e "falso" não se apliquem aos quadros, mas segundo os lógicos, apenas a declarações e proposições, a convenção nos faz considerar as legendas dos quadros como declarações abreviadas: "Sem muito trabalho mental, todos nós podemos transformar em declarações as sucintas etiquetas que encontramos em museus e em livros" (p. 59).

E, no nosso caso, nem tão sucinta é a legenda que acompanha o quadro aqui em questão, o que facilita a validação da cena retratada, por nós ou por tantos outros que a viram e ainda a verão. Pode-se até, ainda segundo Gombrich, discutir se os fatos na cena representados são falsos ou verdadeiros, concordar ou não com o seu autor na adaptação feita da paisagem para compor o cenário, com a escolha do modelo que seu pincel transformou, no caso, em Beja e nos demais atores que completam o quadro, sem com isso, no entanto, invalidar a declaração expressa pela legenda.

Assim, seguem as informações dadas pelo quadro e sua legenda: a temporalidade é definida, bem como o caráter físico-social da personagem e o conteúdo psíquico da cena, parte da origem do mito. Nesse caso, “(...) as palavras presentificam-se no movimento narrativo das imagens, e governam invisíveis nosso entendimento e emoção" (Almeida, 2001, p. 105).

\footnotetext{
${ }^{53}$ Ver anexo 13.

${ }^{54}$ Ver anexo 14.
} 
Nesse sentido, a intenção de Ferreira, ao ser contratado para pintar uma longa narrativa, pode ter sido que suas cenas representassem a história das fontes, a dos banhos nas mais diversas civilizações e, ainda, a pré-história e a história geológica do Barreiro, num mesmo espaço, o das Termas.

Fazendo Beja parte dessa história, Ferreira conduziu, ou ao menos tentou conduzir, nosso olhar para o significado pretendido para ela nesse tempo, o de heroína popular, imagem favorável às pretensões da política cultural do governo de Getúlio Vargas, da qual o autor era porta-voz, contratado que fora pelo governo de Minas Gerais para realizar, juntamente com outros artistas, a ornamentação interna do Grande Hotel do Barreiro.

Portanto, Ferreira, o artista plástico, deveria cumprir sua tarefa obedecendo a uma expressão figurativa determinada pela política cultural do regime Vargas que, entre as suas realizações (montagem do Serviço do Patrimônio Histórico e Artístico Nacional (SPHAN), reinvenção do barroco mineiro, reforma dos cursos da Escola Nacional de Belas Artes, entre outras), incluiu a encomenda de murais históricos como os feitos por Ferreira, os quais acabaram sendo parte desse "empreendimento de legitimação visual, propiciando à elite política e intelectual do regime Vargas o repertório pictórico ajustado à representação espiritualizada do enlace que seus integrantes foram construindo com a história cultural e social do país" (Miceli, 1996, p. 16).

A Beja mostrada por Ferreira, assim como sua história contada nesse painel e nos demais nos quais aparece como protagonista, embora originadas na memória preservada pela tradição oral, foram uma escolha para a qual, como vimos, contribuíram não só a vontade do artista. Na sua escolha atuaram, de forma decisiva, as pretensões manifestadas pela ideologia política do grupo responsável pelo planejamento e pelos recursos financeiros necessários à obra do Grande Hotel do Barreiro, o governo estadual, como também aquelas que obedeceriam a estratégia do governo varguista de manter a integração nacional.

Assim, Beja, que nesse mesmo ano de 1942, no jornal O Diário de Paracatu, acabara de receber o título de heroína, dessa vez, não por sua participação na devolução à província de Minas Gerais das terras do Triângulo Mineiro, mas como participante da Revolução de 1842 (Olympio, 1942) ${ }^{55}$ viu-se também envolvida como parte integrante na

\footnotetext{
${ }^{55}$ Como vimos no Capítulo I desta tese, municípios mineiros e paulistas rebelaram-se contra a redução de sua autonomia, prescrita pelas reformas do Código do Processo as quais foram realizadas pelo poder conservador, maioria no gabinete de D. Pedro II.
} 
construção da história de um poder federal que se firmara, ao longo de doze anos, política e culturalmente.

Ainda no que diz respeito à análise pictórica aqui proposta, vê-se que é possível recortar a cena em que Beja atua como protagonista da seqüência narrativa que se estende pelas paredes do interior das termas, em seus dois níveis e pelos vitrais da cobertura, sem com isso comprometer o entendimento dos mitos ali representados, alegoricamente, por Ferreira:

\begin{abstract}
Alegórico porque aglomera num só momento expressivo (estético) acontecimentos, seres, símbolos, ações e narrações de diversas e diferentes origens temporais e espaciais de outros tempos e povos. Aglomeração, síntese e expansão. Criação de personagens oriundos de narrativas diversas, inexistentes ou sobre os quais não se tem certeza de terem existido. Uma alegoria que toma forma estética na representação pictórica, quase naturalista, que se movimenta em sequiências narrativas, sustentadas pela razão cronológica, aproximando-se, pela verossimilhança naturalista espacial e temporal, à exposição de uma verdade. (Almeida, 1999, p. 31)
\end{abstract}

Cabe-nos observar ainda o roteiro traçado por Ferreira ao transformar o mito, enquanto narrativa histórica pertencente à tradição oral e escrita, na fábula, sendo essa pintada em imagens por ele registradas para serem vistas nesse cenário intencionalmente criado para a reconstrução da memória: a de Beja, a do Barreiro e a de São Domingos de Araxá.

No que diz respeito à nossa personagem, não nos cabe indagar se o retrato dela pretendido pelo artista é verdadeiro, no sentido de apresentar ou não semelhanças com a imagem registrada pela história, a oral e a escrita. Seria inútil. O que imaginamos é que Ferreira deve ter saído a campo em busca de informações para o quadro. O seu temperamento certamente conduziu-o na organização dos elementos que utilizou em sua composição, pensando como Zola que assim define a obra de arte: "um canto da Natureza visto através de um temperamento" (Zola, s.d., p. 176).

Portanto, ao artista coube a escolha ou a adaptação de um cenário para compor a história da Beja, heroína popular que representou seu papel sem deixar documentos visuais capazes de conduzir Ferreira nessa aventura.

Voltando-nos mais especificamente à vida de nosso artista, Joaquim Rocha Ferreira era ex-aluno da Escola Nacional de Belas Artes do Rio de Janeiro, onde conheceu Calmon Barreto, artista araxaense; foi premiado em várias edições do Salão Nacional de Belas Artes; sua escolha para a empreitada artística no Grande Hotel do Barreiro, deveu-se ao prestígio de um amigo, o engenheiro José Ferreira de Andrade Júnior, um dos responsáveis pela obra. 
Ferreira era um artista que conhecia a técnica de seu ofício e conhecia, por sua proximidade com Calmon Barreto, a história de Araxá e de Beja.

Tendo em vista o contexto artístico no tempo de Ferreira é possível concluir que:

(...) não havia possibilidade de se viabilizar uma carreira artística ou literária fora dos marcos institucionais dominantes. (...) No caso dos artistas plásticos, tal exigência se traduzia pela inevitabilidade de se adquirir uma iniciação sistemática e prolongada nas tradições, procedimentos, valores e linguagens veiculados pela Escola Nacional de Belas-Artes, ao que se seguia por força a obrigatoriedade de uma participação regular nos Salões anuais. (Miceli, 1996, p. 18)

Dessa maneira, para formular nossa hipótese sobre a construção da personagem Beja nessa primeira representação pictórica, temos, agora, o fato de que Ferreira já conhecia o mito e, talvez, bem. Tinha de Beja a idéia, sabia-a bela tanto quanto aqueles que dela falavam ou falaram, fato decisivo para o resultado de sua obra, que agora vemos já que: "o familiar será, sempre, o ponto de partida para a representação do desconhecido; uma representação existente exerce sempre certo fascínio sobre o artista, mesmo quando ele se esforça para registrar a verdade" (Gombrich, 1986, p. 72).

Fora assim, então, que a personagem Beja tomou forma. Partindo das descrições existentes, Ferreira a elas acrescentou o seu estilo adequando-o à tarefa encomendada. Nesse processo transformou e adaptou ao novo contexto a idéia que lhe foi transmitida inicialmente, dela apropriando-se de forma criativa.

Enfim, o retrato de Beja na versão de Ferreira resultou:

(...) de um longo caminho que passa pelo esquema e pela correção. Não é o registro fiel de uma experiência visual, mas a construção fiel de um modelo relacional.

Nem a subjetividade da visão, nem o império das convenções podem levarnos a negar que tal modelo possa ser construído com o requerido grau de exatidão. O que é decisivo aqui é, claramente, a palavra "requerido". A forma de uma representação não pode estar divorciada da sua finalidade e das exigências da sociedade na qual a linguagem visual dada tem curso. (Gombrich, 1986, p. 79)

Falamos, há pouco, em observar o roteiro traçado por Ferreira ao pintar a sua cena. Mas percebemos que o melhor seria dizer, nesse caso, imaginar o roteiro, apoiados no que, a propósito, disse Gombrich (1986): “creio que a imaginação histórica pode superar as barreiras, que podemos entrar em harmonia com diferentes estilos da mesma forma como ajustamos nosso contexto mental a diferentes mídias e diferentes notações” (p. 53).

Portanto, imaginemos o roteiro. 


\section{ROTEIRO \\ BEJA A CAMINHO DA FONTE}

\section{PERSONAGENS}

Beja, a protagonista.

Cavalheiro, o escolhido para passar a noite com Beja.

Dois Escravos, os responsáveis por sua segurança.

Escravos (as), figurantes.

Admiradores, figurantes.

\section{CENÁRIO}

Uma paisagem do cerrado mineiro, caracterizado por sua vegetação rala pontuada por algumas árvores mais imponentes. A claridade que inunda a cena é típica das manhãs da região do Triângulo Mineiro nos meses de primavera e verão (alusão ao horário e às temporadas em que Beja se dirigia aos banhos na Fonte da Jumenta, situada no Barreiro).

\section{CENA}

A história é exposta por Ferreira na dimensão de um pequeno conto e, ao que nos parece, sua forma é também literária sendo a sucinta narrativa que se segue um possível resumo de seu "discurso iconográfico":

Quero contar-lhes a história de uma cortesã e ao final não pensem que a inventei. Seu nome é Beja. Ela é jovem, bem sucedida e bela. Bela porque, todos os dias, dirige-se às fontes do Barreiro onde, em cerimonial privado, banha-se em suas águas. Um imponente cortejo, vindo do arraial de São Domingos de Araxá, deixou em seu rastro a admiração de tantos quantos o viram passar e ganhou o campo. Beja ocupa o centro do quadro, montando, com o porte esperado, um não menos imponente cavalo. Vestida com trajes de montaria em rosa, ela é seguida por alguns de seus escravos e escravas além de admiradores, todos eles a cavalo. Um moço garboso de chapéu na mão aguarda ansioso para ver Beja passar ao mesmo tempo em que, finalizando a história, dois escravos distintamente vestidos em libré vermelha esperam por sua ama com flores e presentes. 
Para Charles Baudelaire "que poeta ousaria, ao retratar o prazer causado pelo aparecimento de uma grande beldade, separar a mulher do que ela veste” (apud Griffin, 2001, p. 79).

Para nós que acompanhamos Beja já há algum tempo, sabemos da importância que ela dava à moda, já que a usava como um dos instrumentos na criação de sua beleza lendária. Tal fato foi registrado pela tradição oral e traduzido para o relato escrito, o que nos leva a concluir que Ferreira, ao usar o rosa para o figurino de sua personagem, também o sabia, ou se não, procurou distinguí-la com esse artifício, mostrando-a em sua singularidade.

A cor rosa, pelo que nos diz Gilda de Melo e Souza (1987) estaria ao tempo de Beja destinada aos trajes para se ir ao baile e à Ópera, parecendo, assim, inadequada para o figurino da personagem no mural. (p. 64) O figurino, por sinal "revive as linhas gerais da silhueta de 1830, dando enorme realce às mangas e, pelo contraste, à cintura fina” (p. 68).

Podemos, para continuar refletindo sobre a cor rosa do figurino de Beja, lembrar que essa cena, assim representada por Ferreira, conta-nos a história de uma cortesã para quem se vestir bem significava saber o que vestir e quando.

Assim, por que não arriscar o rosa pela manhã, quando ao passar montada em seu cavalo, Beja tinha a intenção não só de dirigir-se ao Barreiro, mas também de escolher o eleito que com ela passaria a noite no Jatobá?

Para essa tarefa em que atrevimento e sedução se impunham, o vestuário e sua magia cumpriam a sua função deslumbrando a todos quer pelos tecidos e outros detalhes como laços, rendas, chapéus emplumados, quer pelas cores, em suas aplicações costumeiras ou em sentido transgressor de forma a atrair todos os olhares. Os das mulheres que, mesmo desaprovando Beja, se sentiam atraídas pelo inusitado; os dos homens pela intenção por ela pretendida, a de agradar aos olhos, ao mesmo tempo em que, enquanto significado do uso da cor, poderia ser traduzido como um gesto de ousadia e de cumplicidade no jogo da conquista.

Nessa cena, a vestimenta foi criada por Ferreira tanto como elemento constitutivo da composição, como também para corroborar na criação da atmosfera. Longe de obedecer aos rigores dos traços distintivos da moda usada na época, sua intenção parece ter sido a de atingir a certos fins ligados à caracterização da personagem. Beja, ao vestir o figurino, incorporou os significados simbólicos - a atração e a sedução - sugeridos pela cor inusitada, o rosa, ostentando-os como elementos essenciais ao seu espaço social e psicológico. É também a magia criada pelo uso da cor rosa no figurino de Beja que conduz nosso olhar para a sua figura, transformando-a em foco da cena representada. 
Visto em sua forma, o traje de montaria usado por Beja nada perde em sua função narrativa ao sugerir a sensualidade da personagem, estabelecendo com ela um vínculo de identidade que também pode ser visto como a própria elegância. Podemos dizer, ao olhar para Beja em seu figurino rosa, que ela completou com o corpo, os gestos e o colorido pretendidos por Ferreira.

Enfim, é ao figurino rosa que se deve a caracterização da personagem de Ferreira, mesmo porque a sua fisionomia não nos intriga, nem tampouco provoca nossa imaginação e em nada se parece com a Beja da história de Totinha ou a da história contada pelo Correio de Araxá.

À semelhança de uma personagem teatral, a caracterização da Beja criada por Ferreira passa pelo que ela revela a respeito de si mesma e pelo que ela faz. Ao se revelar viu-se que é o figurino rosa que traduz o que Beja deseja nos confidenciar a propósito de sua vida, assim como é ele que transforma o ato de montar em uma ação singular interpretada de forma a fixar características distintivas da personagem. Dessa maneira, seguindo as pegadas deixadas pelo figurino rosa pudemos acompanhar o artista em sua tarefa de montar a personagem em sua forma visual, social e em seu modo de ser, o que fez cumprindo os propósitos da fábula que lhe coube contar sobre Beja. Fácil não deve ter sido para Ferreira organizar os traços que poriam de pé o esquema por ele traçado da personagem, sabendo que:

\footnotetext{
Ninguém é como é porque sim. O fato de ser como é levará esse alguém a ser diferente dos demais, e a comportar-se de maneira diferente. Pode ser que não interesse ao autor - e que nem o preocupe propriamente - apresentar com muitos detalhes o caráter que criou. Mas, como numa pessoa viva, esses detalhes existem; apenas, não foram declarados. (Pallottini, 1989, p. 67)
}

Talvez, por pensar nisso, o nosso autor foi tão minucioso ao realizar sua composição.

Para tratar desse aspecto continuaremos com Alberti o qual nos acompanha desde a nossa entrada no Grande Hotel do Barreiro e qualificou os seres retratados pela pintura "de seres quase vivos", o que nos fez assim pensar sobre Beja.

Diz Alberti (1989): “A maior obra do pintor não é um colosso, mas uma história. A história proporciona maior glória ao engenho do que o colosso" (p. 107). E, dada a história ao pintor para ser pintada, recomenda Alberti que esse deve fazê-la bela. Para tanto deverá o pintor "fazer os esboços e modelos da história no conjunto e em cada uma de suas partes" (p. 137).

Tentemos, a partir do que disse Alberti, observar o que foi acrescentado por Ferreira na caracterização de sua personagem, assim como o que os figurantes, que foram por ele escolhidos para a cena, dizem sobre ela e sua vida nas diversas partes do conjunto. 
Do cortejo que segue Beja, cortejo esse formado por escravos e escravas, além de admiradores, todos montados, quer Ferreira que conheçamos como Beja se "caracteriza socialmente". Até aqui a legenda nos fez ver no que Beja nos confidenciou (ou o seu figurino rosa), o que ela fez (montar com singularidade um imponente cavalo) e tudo o que ficou dessa forma sugerido. Agora, ao observar o cortejo, podemos definir, com clareza, sua posição social: Beja é uma senhora rica, poderosa e livre.

Do que ocorre à frente de Beja, ou seja, o moço que a aguarda para vê-la passar, percebemos o comentário explícito sobre sua atividade de cortesã, de modo que tal característica é reforçada pelo que representam os presentes e as flores com que seus escravos a esperam, encerrando o conjunto observado na composição de Ferreira.

Foi com esses retoques que Ferreira completou a caracterização de sua personagem. Assim, pelas funções observadas nos demais atores que compuseram a cena, imagina-se que essa foi planejada de forma que: “(...) tudo o que os personagens pintados fizerem entre si ou com o espectador deve ser para ornamentar ou ensinar-nos a história”.

A história desse quadro termina aqui levando-nos a acrescentar que a habilidade do pintor, ao contar a sua história de Beja, permitiu ao espectador "pensar em muito mais do que realmente vê" (Alberti, 1989, p. 115).

Passemos ao segundo quadro pintado por Joaquim Rocha Ferreira. Trata-se, dessa vez, de um mural de azulejos ${ }^{56}$ localizado num dos corredores do andar térreo, do Grande Hotel do Barreiro.

Pintada em sépia, a cena histórica que também pode ser de costumes, não nos sugere, como nas Termas, um possível roteiro traçado por Ferreira. Somos convidados a apenas observar, nessa primeira aproximação, somente o que o pintor quer que vejamos: Beja, numa liteira carregada por dois escravos, passa pelo centro da tela, alterando com sua presença o cotidiano do que parece ser a praça central do arraial de São Domingos de Araxá, sendo esse representado pelas atividades próprias da economia rural mineira no século XIX. Completando a cena que se desenrola em primeiro plano, os indicadores da condição social de Beja são explicitados pela presença do cavaleiro que a acompanha admirado, seguindo adiante da liteira, e pela admiração também presente no olhar de uma mulher que, acompanhada por uma mucama, ocupa o lado esquerdo do mural.

Assim, a personagem Beja criada por Ferreira, ao aparecer sendo conduzida numa liteira em seu passeio, deslocou-se das representações que a tradição, seja a oral ou a escrita,

\footnotetext{
${ }^{56}$ Ver anexo 15.
} 
registrou na memória familiar e pública. Beja não usava liteiras em seus passeios. Fazia-os a cavalo ou a pé.

Talvez, seja essa a causa do estranhamento que sentimos ao observar o mural pintado por Ferreira. Acompanhamos a história por ele contada sem a emoção que, como disse Alberti (1989), deve envolver o espectador, convidando-o a partilhar, com simpatia e imaginação, dos sentimentos das figuras retratadas.

Ao conduzir nosso olhar Ferreira deixa claro que, nesse quadro, sua pretensão foi evocar a história da época em que Beja viveu, sendo a liteira, assim, um dos detalhes que o ajudaram a compor a imagem pretendida. Nesse sentido consideramos, ainda como indício da intenção em apresentar um panorama histórico mais eloqüente do que a personagem em si retratada, o cenário que rodeia a imagem de Beja tanto no que diz respeito ao traçado da dupla paisagem, a rural e a urbana, como nos traços culturais evidenciados que caracterizam o interior das Minas Gerais nas décadas de 30 e 40 do século XIX.

Portanto, se observa que Ferreira, em sua pintura histórica, homenageia uma personagem feminina que representa, por sua participação no cenário político e social de seu tempo, o papel de heroína popular. Sua presença no mural dá colorido à história local, foco da crônica visual pretendida pelo artista.

Nesse caso do mural de azulejos pintado em sépia, houve por parte de Ferreira uma preocupação maior em manter a visão idealizada e romântica do cotidiano popular, a qual com uma inserção de fato verdadeira da personagem na cena por ele montada não ocorreria. Ferreira dependia das iniciativas governamentais e nelas talvez não coubesse uma proposta estética de favorecimento do modelo, ao menos não nesse mural.

Além desse aspecto resta-nos observar que Ferreira não utilizou, como tantos outros artistas, a liberdade criativa possível em seu tempo, o que, certamente, teria dado a Beja o espaço narrativo necessário ao seu papel de protagonista. Não tendo se preocupado, ao pintar essa cena, em persuadir e comover o observador com as ações nela representadas por suas personagens, Ferreira deixou esse responsável por sua correção.

Dessa forma, embora Ferreira já dispusesse de um esquema para sua personagem, o que criara no mural das Termas, preferiu, nesse momento, utilizar um modelo desconhecido para realçar uma situação histórica, não focalizando a personalidade de Beja ou suas “conhecidas" características individuais. Beja perdeu, nesse espaço, a desejável coerência que deve acompanhar a caracterização de um personagem, "capaz de convencer e de cobrar uma espécie de existência própria" (Pallottini, 1989, p. 65). 
Resta notar que Beja já era conhecida através do mito, e dada essa condição, sua caracterização já estava determinada pela tradição, assim como as ações que iria representar. Ao público, porque aqui o que nos motiva é a lembrança da tragédia grega, ou ao observador do mural de azulejos pintado em sépia, que, segundo Alberti, deveria ser comovido e persuadido pelo pintor, interessa "de que maneira" Beja faria o que a ela estava destinado, por seu papel, nesse espaço em que sua liberdade já se encontrava previamente limitada pelo mito (Pallottini, 1989).

Ao retratá-la em seu passeio de liteira, o pintor preocupou-se, sobretudo, com os elementos necessários às suas intenções de contar a história de uma cortesã bem sucedida em seus negócios privados e públicos (não podemos nos esquecer do seu envolvimento político na questão das terras mineiras), conferindo-lhe a dignidade e o prestígio pretendidos sem, no entanto, preocupar-se com a verosimilhança.

Acompanhamos Ferreira quando da caracterização de sua personagem nas Termas e vimos que Beja representou com certo sucesso seu papel. Isso nos faz pensar que, nesse caso, a falha de Ferreira deveu-se à organização equivocada dos muitos elementos de que dispunha para compor a personagem e sua história. "Assim, a verossimilhança propriamente dita, (...) acaba dependendo da organização estética do material, que apenas graças a ela se torna plenamente verossímil" como ponderou Antônio Cândido (1970) ao tratar da personagem do romance, acrescentando que: "mesmo que a matéria narrada seja cópia fiel da realidade, ela só parecerá tal na medida em que for organizada numa estrutura coerente" (p. 75).

Ora, o estranhamento que sentimos diante do mural de azulejos pintado em sépia faz-nos lembrar que: "Na dramaturgia clássica, verossimilhança é o que, nas ações, nos caracteres, na representação, parece verdadeiro ao espectador" (Pavis apud Pallottini, 1989, p. 20).

A questão que se coloca, portanto, é como nós observadores recebemos a mensagem transmitida pela obra de Ferreira. E, a nós, tanto a representação de Beja em seu passeio de liteira, como a sua caracterização, não nos convenceram havendo, assim, algo de errôneo naquela tradução cultural realizada por Ferreira da história de Beja, tradução essa a ele confiada para narrar e dar, pela primeira vez, existência visual a tal história.

Afinal, constatamos que nada foi acrescentado à personagem Beja nesse mural que nos auxiliasse na outra etapa: observar o próximo mural ${ }^{57}$, também em azulejos, no qual Ferreira pinta, em azul, a nudez de Beja.

\footnotetext{
${ }^{57}$ Ver anexo 16.
} 
Ao entrarmos na Fonte Dona Beja o mural está adequadamente colocado sobre a gruta de onde correm as águas do Barreiro. É necessário ter presente que “(...) cenas históricas ou retratos são mais do que esquemas pictóricos, são estruturas narrativas cujos significados iconográficos são profundamente engendrados pela cultura" (Costa, 2002, p. 97). Isso porque, indo ao Grande Hotel do Barreiro com a intenção de observar na obra de Ferreira a construção da personagem Beja, pudemos acompanhar em seu trabalho a memória do tempo de Beja, no que se refere, sobretudo à representação da mulher no século XIX.

Dos três gêneros que, nesse tempo, caracterizaram a aparição da figura feminina na pintura, Ferreira utilizou, na década de 1940, as cenas de costumes e, no mural, o nu artístico. Deixou de lado apenas o retrato, por não ser esse um gênero adequado à longa narrativa que, seguindo um contrato, deveria ter como base a ideologia política de seu cliente, o governo de Minas Gerais. Tudo isso nos leva a pensar que o artista trabalhou pressionado tanto pelo predomínio do estilo acadêmico, como pelo patronato estatal da arte, fatores que, possivelmente, foram decisivos na construção da personagem Beja.

Mas, a propósito do retrato, e pelo que vimos ao acompanhar o artista no processo de construção de sua personagem, no qual pudemos observar os temas por ele tratados em estilo e tendências vigentes em seu tempo e no de Beja, nada nos impede de imaginar uma possível tentativa de Ferreira.

Certamente, ele faria Beja de acordo com "a força do modelo estético dos retratos femininos, expressando orgulho, distinção e autoridade", (Costa, 2002, p. 106) característica marcante nesse gênero de pintura no século XIX. Essa característica se manteve, como na pintura de Ferreira e de muitos outros artistas, nos traços que, plasticamente, delinearam a figura feminina na pintura modernista: "A elite brasileira tinha, em sua maioria, um gosto bastante passadista $\mathrm{e}$, às vezes, preferia ter seus retratos em uma estética ainda acadêmica. (...) Essa prática ultrapassa a metade do século XX e, em alguns lugares, chega aos dias atuais” (p. 133).

Assim, como nas cenas de costumes, o retrato de Beja não revelaria o seu comportamento desafiador nem o único traço permanente de seu caráter: uma irreprimível avidez de transgressão de normas. Pensamos ser essa, uma conseqüência não só dos sentidos pretendidos por Ferreira em sua obra, como também dos parâmetros utilizados por ele na leitura e interpretação da história de Beja.

No já visto, voltamos às cenas de costumes. Nelas registramos como evidência da permanência de uma memória, a do século XIX, a atmosfera romântica composta pela natureza, pela disposição cênica das figuras e das coisas que narram a história e, no mural das Termas, a criação de Beja: jovem e sensual em seu figurino rosa. 
Podemos agora entrar na Fonte Dona Beja e observá-la na forma como Ferreira idealizou a história dos banhos de Beja, os quais a fizeram famosa em seu tempo e no nosso.

A tarefa, convenhamos, não deve ter sido fácil.

Caberia ao pintor compor a história dos banhos diários de Beja nas águas minerais do Barreiro, fonte inesgotável da beleza do mito. Ferreira se dedicou à sua obra inteirando-se das muitas histórias que sobre o fato eram contadas, no que nos parece ter utilizado do procedimento aconselhado por Alberti (1989) aos pintores interessados em obter prestígio:

Durante a pintura devemos estar abertos a todos os que vêm, e ouvir a cada um. A obra do pintor procura agradar a multidão. Não se despreze, pois, o julgamento e o parecer da multidão, quando for possível respeitar-lhe a opinião. (...) Ouça portanto, a todos, e pense bem sobre tudo e se corrija interiormente; depois, quando tiver ouvido a todos, acredite nos mais experientes. (p. 139)

Por tratar-se de cena fundamental na trama que se teceu sobre a história de Beja e, acrescentando-se a esse aspecto o de que a imagem da personagem, nesse afazer, ainda não fora cogitada, pode Ferreira criá-la conforme o muito que ouviu dizer.

Mas, depois de ouvir a todos, o pintor selecionou os caracteres necessários à construção de sua personagem, na forma que imaginou ser a esperada pelo público: além dos traços de beleza e sedução, foram a ela agregados os de delicadeza e ternura os quais acabaram por abrandar o caráter de cortesã fria e calculista já incorporado ao mito.

E, assim, vemos a Beja pintada em azul no painel de azulejos.

A sua nudez se encaixa perfeitamente, por suas peculiaridades estilísticas e formais, no gênero que respondeu, ao tempo de Ferreira, pelos nus artísticos. Vindo da Escola Nacional de Belas Artes do Rio de Janeiro, trouxe com ele, a forma de representar plasticamente a nudez feminina, ou seja, aquela derivada dos exercícios com modelos vivos, parte integrante da formação artística acadêmica.

Dessa maneira, Beja nua se aproxima de tantas outras mulheres que, como modelos vivos, perderam sua própria identidade. O contorno do corpo delineia em forma e gesto a atitude impessoal que caracteriza a nudez feminina na pintura neoclássica, estilo esse predominante nas telas de muitos pintores brasileiros que ao gênero se dedicaram, ao final do século XIX e, para além dele, como vemos no mural de Ferreira. Percebemos em suas intenções o desejo de externar a expressão dos sentimentos, dos gestos, da mímica, da sedução, como aspectos significativos da existência corporal de Beja, traços que bem poderiam retratar o espaço sociocultural em que viveu a cortesã, não fossem as convenções estilísticas que conduziram o seu pincel. Assim, podemos atribuir a esse fator o resultado ao 
qual se aplica o comentário de Cristina Costa feito a propósito dos nus artísticos na pintura neoclássica: "Mas, apesar da nudez da modelo, a pose acadêmica, a artificialidade dos gestos e a expressão insípida, típicas dos nus, tornavam as mulheres dessas pinturas menos sensuais do que as das cenas de costumes" (Costa, 2002, p. 93).

Complementando a composição que traz Beja nua como foco da cena montada por Ferreira, vamos encontrar o que para Alberti (1989) assim parecia:

Louvarei toda e qualquer riqueza que pertença à história. Acontece que a copiosidade do pintor acarreta muita satisfação - o espectador se detém a olhar todas as coisas. Mas eu gostaria que essa riqueza fosse ornada de uma certa variedade e fosse ainda moderada e grave de dignidade e discrição. Critico os pintores que, querendo parecer copiosos, não deixam nada vazio. Isso não é composição, mas confusão dissoluta que se alastra. (p. 112)

Sem deixar a figura de Beja em sua pose forçada e em nada perturbadora, vemos que ela é servida por uma mucama a qual demonstra presteza, em atender aos desejos de sua ama, ao estender-lhe a toalha.

Da mesma forma, sem que tal cena, foco da história narrada, nos impressione, passamos "a olhar todas as coisas".

Dirigimos nosso olhar para o lado esquerdo do mural e lá, entre exuberante vegetação e, ainda, às margens de um lago, quatro peões repousam. Deve-se à história essa presença no mural. Ao menos assim se ouviu contar. Quando Beja saía, fosse a passeio ou por qualquer outro motivo, fazia-o escoltada. Houve certa ocasião em que José da Silva Botelho, fazendeiro bem sucedido, se encarregou da tarefa: "Tudo era feito com discrição e zelo. O próprio José ia sempre à frente, com seus seguranças, limpando o caminho para a dama passar." (Rosa, 1997, p. 43)

Atrás, colocado sob uma árvore frondosa que delimita o primeiro plano, um cão parece guardar uma arca. Ao conjunto, perfeitamente dispensável, se ajusta a crítica de Alberti dirigida aos pintores que, querendo ser copiosos, "não deixam nada vazio." Ao que acrescentamos que tanto o cão como a arca, possíveis indícios cenográficos e suas possíveis interpretações, não eram necessários à construção da personagem nem ao papel a ser por ela cumprido. Sabendo das pretensões de Beja nessa cena, Ferreira deveria também saber o que mostrar. No caso, a escolha não seria diferente da realizada pelo autor teatral quando da decisão do que mostrar do seu personagem ao espectador: "Importa, então, finalmente, saber como se vai mostrar o como do personagem" (Pallottini, 1989, p. 69).

Vê-se, portanto, que a Beja do figurino rosa, a da liteira e a da nudez duvidosa constituem-se nas pinturas de Ferreira como "um espaço estratégico de negociação de todo 
um repertório de atributos e desqualificações, de deveres e poderes, de presenças e ausências, de máscaras e parentescos, a imagem final tomando contorno em meio a tais transações" (Miceli, 1996, p. 22).

Para nós importou acompanhar o artista na tarefa de transformar e adaptar o seu objeto, a imagem de Beja, dando a ela uma existência visual que funcionaria a partir daí como instrumento da construção do mito, o qual, por sua vez, daria realidade visual e existencial à personagem, sendo essa carente tanto de provas factuais como de qualquer prova visual. Assim, ao restringir a nossa observação à série iconográfica pintada por Ferreira, nos aproximamos da construção da personagem plasticamente representada num determinado momento histórico.

É válido salientar que o repertório de informações, que buscamos no intuito de compreender o projeto de construção de uma imagem visual para simbolizar uma heroína popular, acabou por nos qualificar para melhor avaliar os elementos constitutivos das abordagens que faremos a seguir.

Assim, mesmo não tendo esgotado o nosso interesse no exame das pinturas de Ferreira, preparamo-nos para deixar a Beja do Grande Hotel do Barreiro e continuar em nosso propósito declarado ao iniciar esse capítulo: acompanhar a construção da personagem Beja durante o tempo que transcorreu entre a história contada por Totinha e a que seria interpretada por Maitê Proença na telenovela exibida em 1986 pela Rede Manchete.

\section{TEATRO}

Uma outra Beja deixou o estúdio do pintor para ocupar camarim e palco no teatro.

Sua possível atuação em peça teatral escrita por Viriato Correa seria uma das atrações na inauguração do Grande Hotel do Barreiro, prevista para janeiro ou fevereiro de 1945.

Tal não aconteceu.

Apesar de ter sido confiada à Companhia de Teatro de Dulcina de Morais, a qual se encarregou de colocar Beja e sua história no palco, uma antecipação da inauguração do Grande Hotel do Barreiro, determinada pelo presidente Getúlio Vargas, inviabilizou a encenação. Texto e autor tiveram o mesmo destino: foram engavetados e desapareceram nos meandros da administração pública, a do governo de Minas Gerais, a esse tempo comandado por Benedito Valadares, aquele que fora o responsável pela encomenda feita a Viriato. 
Por ter sido adquirido pelo governo mineiro, o texto de Viriato não ficou disponível para negociações futuras, as quais poderiam ter viabilizado a encenação da peça teatral. E, foi, também, por ter sido o texto assim adquirido que, em 1949, Viriato, a propósito de uma possível negociação com interessados em encenar sua peça, assim se colocou em artigo publicado pela Folha de Minas como nos conta Montandon: "A estas alturas, dizia, a obra deveria encontrar-se "dormindo" no fundo da escrivaninha de alguma secretaria, pois "os governos (reconheçamos) têm que cuidar de coisas muito sérias, não podem perder tempo com insignificâncias do tipo de Dona Beja” (Viriato apud Montandon, 2002, p. 115).

Ao que parece a obra "dormindo" ficou, isso mais ainda se levarmos em consideração o que disse Thomas Leonardos (1986) na conclusão de seu livro Dona Beja - a feiticeira do Araxá, lançado a 30 de novembro de 1957: "Viriato Corrêa também escreveu algo sobre vossa vida, para teatro, em peça infelizmente de tão restrita divulgação, que nem eu, empenhado em conhecê-la, pude deitar os olhos sobre tal escrito" (p. 144). Nem a nós que, empenhados também em conhecer o texto e a construção feita por Viriato da personagem Beja, foi dado localizar texto e personagem. Ou melhor dizendo, ter qualquer informação sobre o destino do texto, do título a ele dado, e do destino, no texto, reservado à Beja.

Sobre a história de Beja, disse Viriato em seu tempo não ser mais verdadeira, justificando: "o povo já lhe havia dado coloração de lenda" (Viriato apud Montandon, 2002, p. 115). Nada mais acrescentou nem nessa ocasião, ou noutra qualquer, sobre a sua personagem e o tratamento a ela dado em seu escrito. Tal limitação dispensa-nos de maiores preocupações com o autor e sua obra seja a literária ou a teatral, deixando-nos livres para continuar nossa pesquisa, nesse momento voltada para a difícil tarefa de obter registros de uma possível caracterização de Beja como personagem teatral.

Sem abandonar o campo teatral e mantendo Beja no papel de protagonista, percorremos um longo tempo no qual, embora em outras linguagens dela se falasse, das quais trataremos oportunamente, não houve acolhida favorável para a sua vida em produção teatral.

Em 1980 uma nova encomenda colocou Beja em cena, mostrando que seu potencial de permanência adequava-se também aos palcos.

Dessa feita, sabe-se que a encomenda foi motivada por interesses que dispensavam os objetivos político-culturais que marcaram a produção iconográfica realizada no Grande Hotel do Barreiro na década de 1940, os mesmos que, provavelmente, nortearam o texto de Viriato Correa, já que tiveram o governo de Minas Gerais como responsável por sua idealização e produção. 
Tratou-se de encomenda feita pela Fundação Clóvis Salgado a Mário Prata, fato registrado pela revista Veja por ocasião da estréia:

Para a Fundação Clóvis Salgado, de Belo Horizonte, o teatro mineiro andava sisudo demais, precisando de uma boa sacudida. Assim, encomendou ao teatrólogo Mário Prata, um mineiro radicado em São Paulo, uma peça sobre a figura de dona Beja, um dos grandes mitos da história de Minas Gerais. O espetáculo, apresentado de 8 a 19 de outubro no Palácio das Artes e que no dia 30 estreará em Brasília, seguindo depois para Goiânia e São Paulo, foi bem mais que uma sacudidela. Além das 5000 pessoas que passaram pela bilheteria - um recorde para produções mineiras -, a peça transformou-se num escândalo local pelas liberdades que Prata tomou com a figura de dona Beja. (Apolinário, 1980)

Nesse caso, descartaram-se a idealização de traços de comportamento edificantes e da necessidade de utilizá-los na construção da personagem histórica, personagem essa caracterizada por sua atuação na história de Minas Gerais, como foi do agrado do governo Vargas fazer.

Não houve, para o autor, necessidade de localizar modelos coroados de virtudes cívico-históricas para compor a imagem de uma heroína popular mas sim, uma tendência derivada ou não do teor da encomenda, para apresentar, por outro lado, a prostituta bem sucedida e livre de qualquer traço exemplar que pudesse corroborar com a idéia da personagem anteriormente cultivada, seja nas cores de Ferreira, seja no que imaginamos ter sido o texto de Viriato Correa. Da mesma maneira, não houve interesse pela reconstituição histórico-cultural, porque conforme nos diz o próprio autor: "depois de ouvir historiadores e ler livros sobre ela, concluí que quase tudo escrito a respeito de dona Beja era folclore. Assim, imaginei a peça como um conto de fadas."

Assim, Mário Prata montou o seu conto de fadas e construiu sua personagem, de forma a "sacudir" a platéia com a dominância da alternativa temática por ele escolhida: o sexo e o deboche.

Recheado de palavrões e cenas de sexo, trata-se de um conto de fadas bastante peculiar: nele, dona Beja (interpretada por três atrizes, Branca Luiza, Bete Coelho e Wilma Henriques) é apresentada como uma prostituta bem - sucedida, um hábil produto de propaganda para atrair turistas à estância hidromineral de Araxá. (Apolinário, 1980)

O autor dispensou a associação da história real com a natureza ficcional do conto de fadas, decidindo por eliminar o fundo histórico de seu enredo montado sobre a vida cortesã de Beja. 
Parece-nos não ter faltado habilidade a Mário Prata, o qual utilizou em sua versão "escandalosa" as estratégias necessárias para envolver o espectador. Nesse sentido, o que poderia ser considerado como a vida íntima da personagem foi para o centro da cena, destacando um aspecto, em nada virtuoso, da pretensa heroína.

Não se discute aqui a veracidade dos fatos. Tal análise não seria pertinente ou necessária. O que nos interessa é a ação na peça de Mário Prata, em função de como ele caracterizou a sua personagem. Os fatos que importam, portanto, são os que dizem respeito à Beja "prostituta bem sucedida". Tais fatos que, na história oral e escrita aparecem registrados com impessoalidade, foram subordinados à conveniência do autor e modelados em função da satisfação da platéia, a qual pôde espionar, abertamente, a vida íntima de um vulto histórico-cultural.

Podemos dizer, e ainda o artigo da revista Veja nos avaliza, que o autor devotou-se cuidadosamente às reações pretendidas para seu público, não se esquecendo de prever o escândalo provocado pelas liberdades que tomou com a personagem, liberdades essas expressas nos episódios e incidentes mais significativos que selecionou para fixar a imagem, teatralmente marcante, de Dona Beja.

Assim, apesar do desabafo de Wilma Henriques, uma das intérpretes de Beja, "estou sendo cobrada em meu círculo de relações por fazer a peça"; do incidente enfrentado por Branca Luiza, também intérprete de Beja, com sua família, a qual abandonou o Palácio das Artes na noite de estréia de Dona Beja, protestando contra os deboches; e da intervenção da Censura que atuou em defesa do Hino da Independência; o resultado agradou aos proponentes da empreitada: "Dona Beja deu certo e esse pode ser um novo caminho". Foi essa a declaração do superintendente do Palácio das Artes, Nestor Santana, diante dos sucessos obtidos: de bilheteria; da reação do público e o de ter sido o autor contratado e pago, antecipadamente, para dar vida à Beja em palcos mineiros e de outras paragens. (Apolinário, 1980)

E como ficou a personagem?

Podemos apenas imaginar, apoiados em relatos e notícias outras que não o texto original da peça de Mário Prata. Esse, como o de Viriato, se perdeu, segundo nos disse o próprio autor, quando do nosso empenho em encontrar o roteiro de Dona Beja.

Disse-nos também que a base de tudo o que se criou sobre Beja foi o manuscrito de Sebastião de Afonseca e Silva que, em 1915, colocou Beja nas páginas do Correio de Araxá. Como foi visto anteriormente, quando passamos a acompanhar de perto a construção e reconstrução da personagem Beja, o relato de Afonseca acrescentou o que se ouviu pela voz das narradoras, Beja bela em seus traços e contornos, maior riqueza de detalhes, os quais 
viriam a ser confirmados nos traços fabulosos com que Joaquim Rocha Ferreira exibiria as características físicas, sociais e psicológicas da personagem em seus murais do Grande Hotel do Barreiro.

Além de ouvir historiadores e de ler os livros sobre Beja (a esse tempo A vida em flor de Dona Bêja e Dona Beija - a Feiticeira do Araxá já haviam sido publicados), como afirmou Mário Prata, sabe-se que ampla pesquisa foi realizada pelos responsáveis pela direção da peça durante a montagem dessa, tanto em Araxá, como em Estrela do Sul, no sentido de levantar dados com os descendentes de Beja como nos conta Rosa:

$\mathrm{Na}$ época o elenco chegou a Estrela do Sul para fazer um laboratório, hospedou-se numa pensão que existia num casarão bicentenário e mandou buscar todas as pessoas que sabiam alguma coisa sobre a personagem. Conversei com vários atores, entre eles Jussara Costa e Socorro Vieira, na época duas das grandes damas do teatro mineiro, que fariam papéis importantes na peça, e os acompanhei até a casa de dona Zizi, com quem as duas puderam passar várias horas. A produção da peça se deu por satisfeita com as entrevistas com a tataraneta e foi embora com o elenco. (Rosa, 1997, p. 94)

Fez-se, portanto, a construção da personagem possuindo, ao que nos parece, a história conhecida de Beja, tanto a oral como a escrita.

Orientados que fomos pelas palavras do autor que disse: "depois de ouvir historiadores e ler livros sobre ela, concluí que quase tudo escrito a respeito de dona Beja era folclore. Assim, imaginei a peça como um conto de fadas" (Apolinário, 1980). Sabendo-se que "(...) a rigor, a encenação está sendo pedida, sugerida, orientada pelas palavras do autor, primeiro criador daquele mundo" (Pallottini, 1989, p. 70), podemos supor que do entrelaçamento da reconstituição histórico-cultural com a imaginação, sobressaiu, nesse caso, a capacidade fabulativa do autor. Dessa maneira, a recomposição do passado de Beja foi dispensada diante da necessidade de propiciar diversão e distração para o público do teatro mineiro que "andava sisudo demais, precisando de uma boa sacudida".

Nesse sentido, no "conto de fadas", criado por Mário Prata, o toque ficcional no processo narrativo fez desaparecer a figura de Beja, que cedeu seu lugar à personagem Dona Beja, sendo esta alocada no papel de "prostituta bem sucedida". Tal fato foi utilizado como "um hábil produto de propaganda para atrair turistas à estância hidromineral de Araxá" o que demonstra que a construção da personagem, também nesse momento, foi feita para cumprir o papel determinado por seu criador, Mário Prata.

Como vimos, ele conhecia a história de Beja, oral e escrita, e sendo de Uberaba, cidade situada no Triângulo Mineiro, foi criado em terras rendidas às memórias de Beja - a de 
vítima, a de heroína, a de sedutora, a de prostituta - o que lhe permitiu determinar as pretensões de sua personagem sabendo o que dela mostrar.

Prata, em meio a palavrões e cenas de sexo, mostrou "a mulher-sensação, a mulherpecado, a eterna perturbadora" como quis Thomas Leonardos (1986), cabendo esse perfil, por seu forte caráter teatral, na forma e nos objetivos pretendidos pelo autor.

Assim sendo, e já tendo Thomas Leonardos se insinuado em nossas reflexões, podemos examinar a construção da personagem Beja, agora, nos romances, o dele e o de Agripa Vasconcelos. Deixamos, pois o palco em companhia de Renata Pallottini (1989):

Enfim, e concluindo: desenhar com nitidez e eficiência a imagem desse condutor da ação que é o personagem, eqüivale a criar um dos dois sustentáculos do drama: o outro é a história, o enredo, a fábula. Porém, um dos elementos não vive sem o seu par. Escreve-se uma peça para mostrar alguma coisa que nos parece importante, e o nosso modo de mostrá-la tem que passar por personagens. Que eles sejam capazes de sustentar o peso que lhes é atribuído, isso é fundamental. (p. 76)

Enfim, Mário Prata escreveu a peça para mostrar alguma coisa que lhe pareceu importante e que, além disso, se adequou aos objetivos propostos pela Fundação Clóvis Salgado.

$\mathrm{Na}$ tradução cultural do autor, os contornos, antes difusos, da "prostituta bem sucedida" foram definidos. Deduz-se, então, que fábula e personagem sustentaram o peso que lhes foi atribuído, como nos mostrou a opinião pública mensurada pelo sucesso de bilheteria que foi a exibição de Dona Beja de Mário Prata.

\section{ROMANCE}

$\mathrm{Na}$ tentativa de dar conta da construção e reconstrução da personagem Beja num determinado espaço de tempo, compreendido entre o que ficou por nós conhecido como o tempo de Totinha e o que ainda não alcançamos, tido por nós como o da televisão, esbarramos em um salto temporal transcorrido entre a intenção do governo Vargas de colocar Beja no palco, em 1945, e a efetivação desse intuito num outro momento por Mário Prata, em 1980, portanto, após um longo tempo em que a idéia da peça teatral não foi sequer cogitada.

Para não deixarmos o palco e fracionarmos os poucos vestígios deixados por tais passagens, preferimos quebrar a linha do tempo, pensando ser essa a solução mais adequada aos nossos propósitos. 
Portanto, voltemos a 1957.

A esse tempo pertencem os dois romances que, por terem sido a base para a novela Dona Beija, ocuparão nossas atenções, tendo sempre em Beja e nas traduções culturais dela feitas o nosso foco de interesse.

A opção por tais romances deveu-se exclusivamente por terem sido eles as bases para a novela da Rede Manchete, não atentando, portanto, a motivos como valorizações estéticas, estilísticas, literárias ou históricas, etc.

Nosso objeto de estudo, a vida de Ana Jacintha de São José, Dona Beja, vista em seu contexto histórico e na transposição para a produção televisiva, tem agora muitas feições, as quais podem ser vistas nas diversas formas e suportes oferecidos ao público. Esse também mudou. Diferente daquele grupo restrito do início, formado de caráter privado e quase privativo (apenas a família detinha os direitos autorais sobre a memória de Beja), o público cresceu para além das fronteiras mineiras. Nesse movimento, nossa personagem foi transformada e transfigurada conforme o contexto, estando, em 1957, pronta para transformar-se em personagem de romance.

É dentro desse contexto que pode ser analisado o fenômeno literário em torno de Dona Beja, cuja constante exposição conferiu a seu nome uma representatividade e um caráter comercial com um apelo que, enquanto objeto de desejo, poderia ser extensivo ao produto que o usasse. (...) E daí, também, que como um bom produto comercial, a indústria editorial não pudesse deixá-lo passar despercebido. (Montandon, 2004, p. 172)

E não deixou. Foram lançados em 1957 dois romances, o de Agripa Vasconcelos e o de Thomas Leonardos, os quais ocuparão, sem mais demora, as nossas reflexões.

Obedeçamos uma ordem, digamos, histórica. Foi o romance de Vasconcelos o primeiro livro sobre Beja que chegou à nossa casa em Araguari e, assim sendo, foi o primeiro a ser lido e discutido em família, deixando indícios que nos permitiram retomar, de pronto, muitos dos aspectos que passamos a registrar.

Vasconcelos (1985) nos diz inicialmente: "quem escreveu este romance foi a própria vida em flor de Dona Bêja" (p. 7). Indica-nos assim o título (A vida em flor de Dona Bêja) e o gênero (um romance) de sua obra.

É sabido que o historiador dedicou muitos anos à sua pesquisa sobre Beja, grande parte dela feita em Araxá, Paracatu e Estrela do Sul, locais visitados por Vasconcelos inúmeras vezes. Ainda em sua introdução o autor enfatiza o caráter biográfico pretendido, além de mencionar a origem das fontes e o critério meticuloso com que as selecionou: 
A tradição, que é também história, foi depurada de lendas, comuns a figura de seu tope. Ouvi os anciãos que a conheceram na Diamantina do Bagagem e, entre eles, um escravo que trabalhou em seus garimpos. As lendas inverossímeis foram desprezadas.

(...) Os fatos em geral aqui aflorados foram ouvidos de mais de um informante, e os muitos episódios da época são rigorosamente verdadeiros. $(1985$, p. 7$)$

Antes mesmo de abandonar as indicações que precedem a página inicial do livro e, sabendo ser impossível reconstruir ou explicar a série de atos que resultaram na obra $A$ vida em flor de Dona Bêja - Romance do Ciclo do Povoamento nas Gerais, de Agripa Vasconcelos, aproveitamo-nos de mais um vestígio deixado pelo editor para tentar recontar uma outra história: a de como Vasconcelos construiu a sua personagem.

Nessa série, a que se deu o nome de Sagas do País das Gerais, cabe a Vida em Flor de Dona Bêja o papel de comunicar aos leitores como se desenrolou a parte mais importante do Ciclo do Povoamento desta Província central, objeto de disputas que poderiam ter esfatiado o seu território, do que é exemplo a usurpação dos 94.500 quilômetros quadrados do Triângulo Mineiro. (Apresentação feita pelo editor, Vasconcelos, 1985)

Somos assim informados de que a história pessoal de Beja está articulada com a história do ciclo do povoamento das Gerais, fato que acrescenta ao caráter biográfico pretendido pelo autor, o de romance histórico pretendido pela editora.

Portanto, às pretensões sugeridas, a do autor e a do editor, podemos creditar o romance da vida de Beja. Nele o autor busca refletir sobre como ocorriam as relações sociais e de gênero no cotidiano de uma cidade no interior das Gerais, ao tempo de Beja, além de apresentar, como enfatiza o editor, a história de um ciclo, o do povoamento das Gerais. Assim temos uma história pessoal vinculada com a história de Minas Gerais que, além disso, colocase também como um instrumento de pesquisa acerca das representações da condição feminina no século XIX.

Continuamos com o que nos diz o editor. De acordo com ele, Vasconcelos diz em seu livro que foi graças à intervenção de Beja que as terras, antes mineiras, incorporadas a Goiás voltaram a integrar as Gerais. Esclarece o editor:

Na narrativa desse e de outros episódios, há uma real interpretação da história, em que o autor trabalhou com base em sólidos conhecimentos, revelados através de uma notável capacidade para romancear os fatos, contálos como se estivesse realmente a fazer ficção e, no entanto, manter-se constantemente fiel à verdade. 
Note-se a relação aí estabelecida entre o caráter ficcional e a verdade e mais do que isso, a proximidade entre o texto ficcional e o não ficcional, dependentes intrinsecamente da intencionalidade do autor, ao selecionar os fatos que deverão compor a narrativa. Trata-se, portanto, de uma obra que se coloca como um texto histórico, na medida em que é a partir dos documentos, das fontes encontradas e de extensa pesquisa histórica voltada para a construção de um contexto, que o autor traça os contornos de sua personagem.

Nessa perspectiva, é importante completar o que o editor nos disse a propósito de pertencer o romance A vida em flor de Dona Bêja - Romance do ciclo do povoamento nas Gerais, à Série "Sagas do País das Gerais", (lembrando ser ele o volume número 3 e que Vasconcelos teria contribuído com mais seis títulos para a coleção).

Sob esse aspecto, a obra de Vasconcelos obedece a um plano peculiar: o da biografia de uma mulher incomum que sobreviveu no imaginário regional por sua identidade, beleza e coragem e também por sua atuação no cenário político e cultural de seu tempo. O plano assim traçado contempla não só as intenções do autor, como também a orientação editorial expressa no papel destinado à história de Beja: comunicar aos leitores a forma como se deu o povoamento da Província de Minas Gerais.

Parece-nos claro que o objetivo da história da vida de Beja, contada por Vasconcelos, bem como o da sua contextualização, são essencialmente didáticos. Some-se a esse objetivo a intenção dos editores, a qual manifesta o caráter de divulgação de um período histórico específico, o do ciclo do povoamento nas Gerais, que articulado com outros temas, como os dos ciclos do latifúndio, do agropecuário, do ouro, dos diamantes e da escravidão nas Gerais, todos apresentados em livros pela mesma coleção e produzidos pelo mesmo autor, compõem a história de uma região, pelo encadeamento de suas diversas histórias e de seus respectivos contextos sociais.

$\mathrm{Na}$ incidência de figuras míticas como a de Dona Joaquina do Pompéu, que personifica o ciclo agropecuário, a de Dona Bêja, figura central do ciclo do povoamento, a de Chica da Silva, protagonista do ciclo dos diamantes e a de Chico Rei, personagem que conduz a narrativa do ciclo da escravidão, percebe-se que a reconstrução do passado, o da História das Gerais, reúne biografias de uma galeria de exemplos paradigmáticos da identidade nacional.

A reunião dessas figuras singulares, vistas em sua relação com a história das Gerais, retira da série "Sagas do País das Gerais" o seu caráter regional, transformando as trajetórias de seus personagens num referencial comum, capaz de representar fatos que explicam a memória nacional. 
Nessa transfiguração de Bêja pela tradução cultural feita por Vasconcelos em sua obra A Vida em Flor de Dona Bêja, nossa personagem deixa o Sertão do Novo Sul, ${ }^{58}$ onde tornarase imortal pela preservação de suas lembranças por aqueles que de alguma forma a conheceram, lembranças essas estritamente privadas, para transitar no amplo espaço da cultura nacional.

A mudança de cenário não tirou o brilho da personagem de Vasconcelos. Beja que deveria atuar como coadjuvante na narrativa histórica de um grande ciclo, o do povoamento das Gerais, figurando como mera ilustração, não se subordinou à lógica do discurso histórico, permitindo ao leitor, com sua presença, uma forte identificação com o passado tornando-o inesquecível.

O caráter individual da trajetória de Beja funde-se aos acontecimentos da história, a de seu tempo, o que acaba por nos levar aos aspectos simbólicos e sociais que ligam os fatos do passado ao presente.

A história de vida dessa mineira mítica, agora famosa em outra esfera, pode estar relacionada ao que nos diz Vasconcelos (1985) na apresentação de sua obra: “(...) o desvairamento do viver de Dona Bêja é que lhe mantém, no país de coisas efêmeras, a lembrança que vai ficando eterna, através das maledicências da História" (p. 7). Poderia também não ser esse o motivo que justificasse sua lembrança constante, se considerarmos que a idéia de escândalo poderia obscurecer o papel de Bêja na história de sua época, pela atmosfera particular criada por sua existência.

Pois bem, interessam-nos a trajetória da personagem e a relação estabelecida entre ela, o autor e a intencionalidade deste.

Ao que parece, tal relação ultrapassou as formalidades estabelecidas pelo editor decorrentes da intenção comercial no lançamento do romance A vida em flor de Dona Bêja. Além de ater-se ao seu ponto de vista na relação com o tempo do lançamento de sua obra, assim como à necessidade de ligar personagem e formação das Minas Gerais, proposta veiculada pela Editora Itatiaia, Vasconcelos não deixou que Beja perdesse a sua independência e as suas características pessoais. O forte vínculo criado entre ele e sua personagem "Bêja" demarcou a possibilidade criativa, ficando sua imaginação sujeita aos limites colocados pela personagem real e a história dela conhecida.

“Mas, imaginado, como? Que pontos de contato guarda o personagem com a pessoa?", pergunta-nos Pallottini (1989, p. 11).

\footnotetext{
${ }^{58}$ Sertão do Novo sul, Sertão Grande, Sertão do Sul, Geral Grande, Sertão da Farinha Podre eram nomes do que se chamaria em 1884, Triângulo Mineiro.
} 
Sendo Beja uma pessoa sempre lembrada pela tradição oral, já tendo sido personagem no relato publicado pelo Correio de Araxá em 1915, e também já tendo recebido, ao tempo de Vasconcelos, o batismo da imagem, como vimos nos painéis de Joaquim Rocha Ferreira, podemos imaginar que todas essas evidências compuseram o repertório do autor. Mas, apesar disso:

Não se trata de ter um personagem que seja a cópia real de uma pessoa qualquer, viva, existente, conhecida do autor. Mas de criar um ser de ficção, que reúna em si condições de existência; que tenha coerência, lógica interna, veracidade. Um ser que poderia ter sido, não necessariamente um ser que é. (Pallottini, 1989, p. 12)

Nesse sentido, no caso da personagem representada por Ferreira nos murais do Grande Hotel do Barreiro, tratou-se "de fazer presentes os ausentes; mais ainda, de fazer dos mortos, depois de muitos séculos, seres quase vivos” (Alberti, 1989, p. 95). Já no romance, a personagem criada por Vasconcelos tornou-se um "ser que poderia ter sido, não necessariamente um ser que é": uma personagem imaginária, criada a partir de documentos, das versões mantidas pela tradição oral e de extensa pesquisa histórica, como nos fez acreditar o próprio autor e, para a qual, ele teria traçado, com os fatos escolhidos para compor a sua história, uma existência cabível no contexto da história do povoamento das Gerais.

Da Bêja de A vida em flor de Dona Bêja podemos dizer que Vasconcelos escolheu combinar os elementos de sua caracterização a partir de uma composição lógica e precisa, composição essa limitada pela determinação da realidade, a da pessoa histórica, Anna Jacintha de São José, que ao ser focalizada pelo autor converteu-se em "Bêja".

Semelhante a Beja que conhecemos, a "Bêja" de Vasconcelos guarda com as versões, por nós até aqui tratadas, e com as que ainda serão, semelhanças justificadoras da afirmação de Montandon (2004) a propósito do "texto fundador" de autoria de Sebastião de Afonseca e Silva, tido como base para a literatura produzida sobre Dona Beja:

A partir da década de 1950, todas as versões literárias que foram escritas, têm como base esse relato e alguns escritores admitem ter conhecido ou tido acesso às anotações particulares de Afonseca, a quem agradecem a colaboração. (p. 168)

(...) o que não o exclui como fonte de quase tudo o que a imprensa e outros memorialistas regionais já tinham publicado a seu respeito. (p. 146)

Como se viu, a imagem de Beja registrada nos murais de Ferreira deu-nos a conhecer, em formas e cores, a mesma personagem registrada em nossa memória pela descrição dela 
feita por Totinha em sua história, que contada ao tempo de Joana e Haydée, inspirou o retrato de Beja descrito por Afonseca: "reunia todos os encantos de uma beleza ideal à esplêndida primavera (...)". ${ }^{59}$ Levando-se em conta a voz das narradoras, o texto de Afonseca e os murais de Ferreira, só deixando de lado a personagem teatral de Viriato Correa, que não nos foi dada conhecer, a "Bêja" de Vasconcelos (1985) foi por ele definida como: "Eterna, porque D. Bêja vence as eras, pela coragem de suas atitudes indomáveis e pela graça quase divina de sua beleza" (p. 8).

Assim, da personagem já temos um contorno. Do autor, por sua vez, além de algumas considerações sobre sua obra, pouco sabemos. Podemos, portanto, fazer uma pausa explicativa, na qual trataremos de Vasconcelos e da história que ele contou de Minas Gerais antes de tratarmos das "atitudes indomáveis" reservadas por ele para "Bêja" em terras mineiras.

Agripa Vasconcelos nasceu em Matosinhos - Minas Gerais, em 1896, e faleceu em Belo Horizonte, em 1969. O médico e escritor mineiro, autor de 21 livros, notabilizou-se com o ciclo de romances históricos que produzira, dentre os quais três foram adaptados para o cinema e a televisão: Chico Rei e Xica da Silva para o cinema (dirigidos por Cacá Diegues e Walter Lima Júnior); e Dona Bêja para a televisão, na forma de telenovela (dirigida por Herval Rossano). Tanto o fato de terem esses romances se adequado às telas, a do cinema e a da televisão, como o do sucesso editorial obtido por ocasião de seus lançamentos, podem ser creditados à farta pesquisa histórico-documental com que o autor cercou a história de vida dos seus personagens, sendo essas contadas de forma a possibilitar desdobramentos para o entendimento da cultura do "País das Gerais".

Consideramos que, do fato do médico-escritor ser mineiro e de ter freqüentado com certa assiduidade o Grande Hotel do Barreiro em Araxá onde, com certeza, conheceu Afonseca e seu "texto fundador", conhecendo também descendentes de Beja, nessa cidade e em Estrela do Sul, por onde passou, dos quais disse o autor, terem sido os que menos informações deram sobre Beja, parte a perspectiva pela qual o escritor vê a personagem em seu tempo e a mediação pela qual ele se comunica com o leitor. Em sua posição de narrador, o autor revela esse pertencimento tanto na leitura dos acontecimentos históricos do "País das Gerais" e da vida de Beja, quanto na sua interpretação feita com a familiaridade daquele que sabe ler entre as linhas que compõem a cultura local.

\footnotetext{
${ }^{59}$ Conforme Capítulo II desta tese.
} 
Voltando-nos mais propriamente à perspectiva histórica abordada pelo autor, vemos que a ênfase dada aos acontecimentos que mapeam a identidade de Minas constitui o referencial da importância dada por ele à sua terra. Vasconcelos traça o contorno das Gerais de forma a abarcar as suas origens, configurando o seu relevante papel na construção da História do Brasil: "O primeiro homem branco a pisar, em 1663, a terra abençoada do Sertão do Novo Sul foi o bandeirante paulista Lourenço Castanho Tacques" (Vasconcelos, 1985, p. 9).

Tomando Desemboque, arraial formado a partir da descoberta de ouro, como ponto inicial da colonização do Sertão Grande, ${ }^{60}$ Vasconcelos registra uma série de acontecimentos históricos, dos quais são pontos relevantes a exterminação dos índios Araxá, a destruição do quilombo do Ambrósio, os processos políticos que transferiram para a Capitania de Goiás 94.500 quilômetros quadrados de terras mineiras, e a descoberta das fontes de águas minerais do Barreiro

Essa reconstrução do passado, traçada na linha do tempo e ritmada pela descrição das riquezas locais e suas incontáveis possibilidades, sinaliza uma versão que abrange, além das já existentes sobre os fatos, uma interpretação permeada pela noção de progresso. Assim, a província mineira, em processo de civilização, rompe os seus limites físicos e apresenta-se como parte integrante do território nacional.

Sem entrar em considerações mais amplas quanto à maneira de o autor pensar a história, seja ela vinculada à uma visão antiga ou moderna, ou mesmo se tratando de uma combinação entre as duas vertentes, cabe-nos atentar para o roteiro pré-estabelecido pelo formato a que se submeteu: o de uma narrativa histórica de um ciclo de povoamento, digamos, enriquecida pela história de uma personagem singular, a de Beja.

Tal disposição justifica a seleção de fatos até aqui observada. Vasconcelos nos fala num primeiro momento da sua personagem histórica, o "País das Gerais", como se estivesse nesse relato a compor o que seria o cenário para a atuação de sua personagem biográfica. A antecipação de parte dos eventos mencionados, assim como o entrelaçamento de outros no corpo do texto, trazem o passado para o presente da história de Beja, transformando-a em parte constituinte da formação do povo mineiro.

“Em 1770 a Aldeola de S. Domingos dos Araxás erguia com lentidão, no planalto, os tetos de taipa das casas humildes" (Vasconcelos, 1985, p. 34). E, tendo tecido o pano de fundo de sua narrativa com os acontecimentos históricos, o autor nos conduz ao já então Arraial de

\footnotetext{
${ }^{60}$ Em torno do Desemboque nasciam aldeias, entre elas as de S. Domingos, Farinha Podre, S. José do Tijuco, Nossa Senhora da Abadia de Água Suja, Arraial da Ventania, Brejo Alegre, Vila de Nossa Senhora da Saúde de Poços de Caldas, S. Bento de Tamanduá, S. Pedro de Alcântara, Nossa Senhora do Patrocínio do Salitre, S. Pedro de Uberabinha, Diamantina da Bagagem, Confusão... (Vasconcelos, 1985).
} 
São Domingos de Araxá, palco do drama que será encenado pelas personagens por ele criadas, porém baseadas na realidade histórica.

Era quase noite quando uns peregrinos chegaram ao rancho de tropas do subúrbio de Santa Rita, no Arraial de S. Domingos. O velho apeou-se primeiro, depondo antes no chão a neta de 5 anos que viajava numa almofada, na cabeça de sua gereba. Ajudou depois a descer a uma senhora ainda moça. (Vasconcelos, 1985, p. 35)

Inicia-se assim a história de Beja contada por Vasconcelos. À Beja o autor destinou um papel capaz de humanizar a história do Ciclo do Povoamento nas Gerais, tornando-a mais verdadeira e mais próxima dos leitores que, mediados por nossa personagem, passam a se identificar com os fatos apresentados.

Dessa história pouco nos ocuparemos, dada a aproximação existente entre ela, a de Thomas Leonardos e, também, as que constituem as nossas Anna Jacintha de São José: uma biografia possível (primeiro capítulo) e A tradução cultural de Beja: personagem e memória (segundo capítulo) referente à nossa história-personagem. Portanto, evitaremos colocações desnecessárias, procurando manter-nos atentos às variações significativas no que se refere à construção da personagem Beja, agora no romance, pela tradução cultural de Vasconcelos e, oportunamente, na de Leonardos.

No romance de Vasconcelos há um direcionamento definido pela perspectiva amorosa, na qual a vida de "Bêja" transcorre entre sucessos e desventuras. Em todos os acontecimentos, a começar pelo rapto, passando por seus dois amores, Antônio e João, pais de suas duas filhas, e por suas infindáveis aventuras amorosas, o enfoque vai para o infortúnio sentimental e para o elogio do caráter determinado da heroína, que com suas "atitudes indomáveis" a tudo supera, conquistando riquezas e perdão para o seu comportamento transgressor, aquele responsável pelo rompimento das regras culturais ditadas pelos padrões sociais vigentes.

É nessa atmosfera que enredo fictício e fatos históricos se fundem e são utilizados pelo autor de forma a que os aspectos sentimentais, por ele acrescentados, dêem aos episódios maior vulto e repercussão. Para tanto, Vasconcelos incluiu em sua narrativa histórias e personagens que, paralelamente, representam o contexto sociocultural de A vida em flor de Dona Bêja. De tais personagens e dos papéis que representam podemos dizer, ou melhor, supor, que foram transpostas de modelos encontrados pelos autor em sua pesquisa documental ou, conforme ele mesmo declarou, nos muitos testemunhos que ouviu durante a sua "extensa pesquisa”. São personagens que apesar de não terem uma participação significativa na trama 
central do romance, a enriquecem e complementam, ao mesmo tempo em que contemplam o caráter de romance histórico pretendido pela Editora.

Portanto, é nesse sentido que vamos encontrar no salão da casa de Beja, em São Domingos de Araxá, vindo da Corte com destino a Vila Do Príncipe, um Deputado Geral. De identidade desconhecida para Beja e para o leitor, o visitante que fora conferir pessoalmente o que de muitos ouvira dizer, sobre a beleza e a inteligência de Beja, acaba por travar com ela um longo diálogo, no qual a Província de Minas Gerais é enaltecida como a pioneira da Liberdade, e do qual reproduzimos o final:

- E qual dos liberais mineiros lhe parece maior?

- Todos são ilustres pois comungam a mesma idéia. O maior é, sem dúvida, Teófilo Otoni.

O Deputado pulou da poltrona, apertando a mão de Bêja, demoradamente. Ele era Teófilo Otoni. (Vasconcelos, 1985, p. 359)

São situações como essa, nas quais personagens inesperados adentram ora o salão de Beja, o da casa da praça da Matriz, ora as dependências da Chácara do Jatobá, incluindo-se aqui as mais íntimas, reservadas aos que por ela escolhidos tinham o privilégio de desfrutar dos prazeres de sua cama, que Vasconcelos usa para traçar o modo de ser da personagem, definindo: "sua constituição psicológica, sua afetividade, emoções, sentimentos. Capacidade de fazer opções e mantê-las; persistência, pertinácia, teimosia. Força de vontade, defeitos e virtudes marcantes" (Pallottini, 1989, p. 65).

Os aspectos destacados por Pallottini permitem-nos avaliar a personagem criada por Vasconcelos e por ele identificada como "Bêja", observando que o autor deu a ela a liberdade necessária à sua maneira de ser, possibilitando, com isso, que Beja sustentasse com naturalidade os acréscimos inevitáveis atribuídos ao seu caráter e às suas ações.

Dessa maneira, não ficamos surpresos com o fato de que as razões do sentimento e as características da personalidade de Beja, apresentadas no romance, conseguissem subtrair espaço à relevância dos acontecimentos históricos, os quais ficaram obscurecidos pelas façanhas da personagem. Estas revelam o bem e o mal, na mesma medida em que o caráter de Beja vai sendo construído entre o vício e a virtude, os ódios irreparáveis e os amores perdidos.

O fato é que sem se afastar das suas fontes, a história oral e o "texto fundador" de Afonseca, Vasconcelos buscou liberdade em seu romance. Na sua versão, a figura de Beja ganhou maior significado e poder de convicção se comparada às outras já aqui aludidas. Tal afirmação é possível, pois a partir da tradução cultural feita pelo autor, na qual foi reservada a 
"Bêja" uma atuação verossímil, que a personagem se revelou como ser de "romance", como nos assegura a passagem de Décio de Almeida Prado (1970) em A personagem no Teatro:

A personagem constitui, portanto, um paradoxo, porque essa criatura nascida da imaginação do romancista ou do dramaturgo só começa a viver, só adquire existência artística, quando se liberta de qualquer tutela, quando toma em mãos as rédeas do seu próprio destino... (p. 101)

No romance, é a própria personagem "Bêja" que conduz, com a mesma autonomia que a caracterizou em seu tempo, o destino a ela reservado por Vasconcelos. E, dele não faz parte o padre Francisco José da Silva, pai da primeira filha de Beja.

Assim como Totinha não nos contou que Thereza Tomazia de Jesus, a primeira filha de Beja, nascida em 15 de fevereiro de 1819, não era filha do Antonio e sim do padre Francisco José da Silva, fato comprovado por documentos cartorários, assim como por ser "público e notório", como afirmou a própria Beja em 1864, ${ }^{61}$ Vasconcelos também não contou isto aos seus leitores, nem o contará Thomas Leonardos em Dona Beija: a feiticeira do Araxá, romance do qual agora nos ocuparemos por ser ele como o de Vasconcelos, a base para a novela da Rede Manchete.

De Leonardos sabemos não ser ele mineiro. Nascido no Rio de Janeiro (1906), sua atração pelo Triângulo Mineiro deveu-se a uma viagem para tratamento na Estância Hidromineral do Araxá, em 1948, quando se hospedou no Grande Hotel do Barreiro. Foi nessa oportunidade que pode "conhecer a fundo a gente e as coisas da terra", inclusive a história de Beja, como nos conta em dedicatória feita em seu livro, para Cleanto Vieira Gonçalves, gerente do Grande Hotel naquela ocasião em que o autor lá se hospedou.

Sabemos ainda, ou melhor, muito pouco sabemos sobre o autor, um advogadoescritor. $^{62}$ De qualquer forma, as informações obtidas nos permitiram avaliar a relação estabelecida entre a personagem, o autor e sua intencionalidade, fatores esses determinantes no modo como Leonardos construiu sua personagem "Dona Beija", sendo que tais informações nos foram fornecidas pelo próprio autor, em declarações feitas nos prefácios das três edições do seu romance.

Antes de pensarmos em tais informações, podemos abrir um espaço para refletirmos sobre os fatores que determinaram as reedições do livro de Leonardos, relacionando-as com o mercado editorial e seus desígnios. Certamente, esta análise nos aproximará da relação entre o

\footnotetext{
${ }^{61}$ Conforme Capítulo II desta tese.

${ }^{62}$ Leonardos escreveu extensa obra jurídica, um romance premiado pela Academia Brasileira de Letras, Os Inadaptados, as biografias de Abraão Lincoln e do Regente Feijó e outros títulos sobre política e história.
} 
livro, a tarefa de escrevê-lo e o conjunto de recursos culturalmente disponibilizados para Leonardos cumprir sua empreitada.

Bem, comecemos.

"1957 foi o ano da Beija", escreve Leonardos em 12 de Abril de 1958, em carta publicada pela revista $O$ Cruzeiro, nos Arquivos Implacáveis de João Condé, referindo-se ao lançamento, nesse ano, de três livros sobre ela: o primeiro, um livro de crônicas, Dona Bêja, de Raul Machado; o segundo, A vida em flor de Dona Bêja, "o interessantíssimo e alentado livro de 510 páginas de Agripa Vasconcelos", ainda segundo Leonardos; e o terceiro, o seu romance, Dona Beija: a feiticeira do Araxá. (1968, p. 18)

Leonardos a princípio pensou em transformar em reportagem as notas que tomara sobre a vida de Beja nas muitas visitas feitas ao Major Sebastião de Affonseca e Silva, em Araxá. Entretanto, confessa: "senti a um só tempo, o apelo do tema e a necessidade duma revisão serena das narrações destorcidas e foi isso que provocou este livro" (Leonardos, 1986, p. 13).

Tendo em vista que a viagem de Leonardos à Araxá deu-se em 1948 e a publicação do livro aconteceu em 1957, perguntamo-nos por que não ter o lançamento ocorrido anteriormente, ou melhor, por que não antes da publicação do livro de Vasconcelos, lançado com sucesso pela Editora Itatiaia? Seria isso devido a uma vontade própria, ou ainda a uma mera dificuldade editorial ou, por outro lado, devido a Beja ter se tornado amplamente conhecida somente após o sucesso da obra de Vasconcelos?

Nossa questão não é determinante. Surgiu em face da dificuldade em aceitarmos, no caso de Leonardos, que a publicação de seu romance fosse justificada em função da vontade exclusiva do escritor, sem outras intenções que não a de atender ao motivo que o impelia: "fazer, como advogado, um trabalho de pesquisa e revisão dos fatos que deixaram a memória de Dona Beija envolta na crosta suja e dura da má fama” (1986, p. 14). Portanto, acreditamos que o caráter comercial creditado ao nome de Beja foi comprovado com a publicação do livro de Vasconcelos pela Editora Itatiaia, o que teria motivado, posteriormente, outras investidas literárias patrocinadas pela indústria editorial como fora a de Leonardos. Nossa sugestão não invalida as razões do autor, mas colocada que foi, permite-nos relacionar essa circunstância com o modo de construção da personagem e os fins a serem atingidos pelo livro de Leonardos.

Nesses fins não estão implícitos como no romance de Vasconcelos a divulgação da história do ciclo do povoamento nas Gerais, bastando para o "romance biográfico" de Leonardos a história de vida de Beja. O que de história acrescenta Leonardos (1986), seja a de 
Minas Gerais, seja a de "âmbito mais largo", ele o faz de forma a poder aconselhar: "quem nisso, porém, não se interessar, poderá sem perda da seqüência da narrativa, omitir a leitura dos Capítulos III a IX e XII” (p. 13).

Escolha e recorte definidos, assim como demonstradas as razões que o levaram a fazêlos, viu-se o autor diante dos recursos disponíveis para cumprir sua tarefa, como nos conta num dos prefácios de Dona Beija: a feiticeira do Araxá, após reiterar seu propósito, um tanto quanto arbitrário, de absolver Beja, contando em livro sua história verdadeira:

Assim, antes de soltar a imaginação, procurei verificar os fatos, lastro indispensável para o romance idealizado. Não larguei mais a idéia. De informação em informação, de obra em obra consultada, cheguei afinal a um inesperado Arquivo do Araxá muito bem organizado, propriedade de um patriarca da cidade, o Major Sebastião de Affonseca e Silva. No volume 26 ele colecionou a matéria de uma obra ainda inédita, cujos originais estão com o Professor Calmon Barreto e que tem o título de_Ana Jacinta de São José (Dona Beija in natura) - sua vida em ordem cronológica do berço ao túmulo - coletânea de narrativas ouvidas.

Foi esse trabalho que me permitiu dar consistência aos fatos que narrei romanceando, e aos quais dei a interpretação psicológica que entendi acertada. (Leonardos, 1986, p. 18. Grifos do autor)

Para Leonardos, portanto, não se tratava simplesmente de agregar ou reunir os episódios conhecidos sobre a vida de Beja, mas de fundi-los na forma do "romance biográfico", na tradução cultural por ele feita de Beja, que em seu novo papel recebeu o nome de "Beija".

Ainda em 1957, no dia 30 de novembro foi lançada em Araxá a primeira edição de Dona Beija: a feiticeira do Araxá, em evento concorrido e antecipadamente anunciado. Affonseca se encarregou de redigir e distribuir os convites, nos quais, em seu entusiasmo incontido, dá-nos os contornos da personagem de Leonardos:

Esta raríssima entidade feminina, com sua elegância e beleza física, dotada de uma fulgurante inteligência em conjunto com uma argúcia admirável e seu fascinante olhar, empolgava e arrastava o sexo masculino com sua presença e selecionava e desprezava conforme suas simpatias. Tornou-se célebre na história, por ter sido o eixo central sobre o qual girou a reincorporação de todo o território do Triângulo Mineiro a Minas Gerais, em 4 de abril de 1816.(Leonardos, 1986, p. 16)

Dona Beija é entregue assim "pronta" aos possíveis leitores de A feiticeira do Araxá, cabendo a Leonardos, apenas, acompanhá-la em sua tarefa de absolvê-la de seus muitos pecados. 
Narrados quando necessário, esses pecados são descaracterizados pelo conseqüente estímulo à virtude o que por sua vez ocorre em enredo cuidadosamente trabalhado de forma a sensibilizar o leitor, fazendo-o partilhar do infortúnio de "Dona Beija", infortúnio esse motivador de suas falhas e de seu perdão.

É assim que, a propósito do assassinato de Antonio Sampaio, do qual sabemos ter sido Beja apontada como mandante, Leonardos (1986) escreve:

Há quem diga que foi Ana Jacinta quem mandou matar Sampaio, porque ele acabou assassinado. Mas o crime só ocorreu depois de um ano do violento rompimento. Por que, pois, ligar um fato ao outro? A hipótese, por certo, não é desprezível, mas afigura-se-nos bem pouco provável. (p. 125)

E arremata após sumária e eficaz defesa: "Tudo o que sabemos, porém, sobre Ana Jacinta faz-nos alijar, por inadmissível, tal versão do crime” (p. 125).

A narrativa de Leonardos se desenrola sem romper com os episódios conhecidos nas demais versões, superando-as, no entanto, no destaque dado a atuação da personagem. "Dona Beija" está impecável nas ações a ela destinadas, nas quais o autor lhe acrescenta com traço firme a linha da virtude e da bondade, nem sempre dosadas de acordo com o até então conhecido caráter da heroína, marcado pela sua capacidade de inverter a ordem estabelecida, sua coragem, seu poder e iniciativa que a dotaram de uma autonomia, desconhecida nas mulheres de seu tempo.

Tal desalinho não desagradou o autor, que assim declarou em entrevista publicada pelo jornal $O$ Fluminense, em 17 de março de 1986: "Não visei engrandecer a vida de Dona Beija: nada disso. Procurei apenas repô-la no lugar que realmente ocupou". Também, se levarmos em conta a rapidez com que se esgotou a primeira edição da obra de Leonardos, podemos afirmar que essa não desagradou ao leitor, no que somos apoiados pelo que disse Edgar Cavalheiro, crítico do jornal O Estado de São Paulo: "Dona Beija sai do seu livro engrandecida, e se ao leitor fosse perguntado se a absolveria de todos os seus pecados, com certeza o veredicto lhe seria, após a leitura de "A Feiticeira do Araxá", inteiramente favorável" (1986, p. 19).

Antes de passarmos à segunda edição do livro de Leonardos, vamos apresentá-lo como o autor da idéia da criação do Museu da Beija. O espaço deveria ser criado na "belíssima casa colonial da Beija", a da praça da Matriz em Araxá, com "seus móveis, suas alfaias, suas jóias", possibilitando, assim, a celebração e legitimação da personagem, manifestou-se Leonardos em carta publicada nos Arquivos Implacáveis de João Condé (1958, p. 47). 
O "Museu Histórico de Araxá Dona Beja" foi inaugurado em 1965 ( ano do Centenário de Araxá), "idealizado" e montado por Assis Chateaubriand, que recebeu todas as homenagens, inclusive as relativas à idealização da obra. Nenhuma menção a Leonardos ou a sua alentada idéia, fazendo-o assim manifestar-se:

Quanto ao MUSEU DONA BEIJA, nada reivindico senão o que presumo de direito me pertença: a prioridade da idéia lançada a público naquela carta a João Condé, divulgada em 12 de abril de 1958. Por isso, quando por iniciativa dos "Diários Associados", aquela mesma revista, em 13 de novembro de 1965, noticiou a inauguração do Museu, confesso que fiquei sentido pelo silêncio que se fez em torno do meu nome. (Leonardos, 1986, p. 20)

Ao que parece, tal sentimento não abalou Chateaubriand, que:

Como de costume, Chateaubriand "fez a (sua) festa" durante a inauguração do museu. Fazendo juz à irreverência, sua marca registrada, e a um poder que ainda lhe permitia desafiar a ditadura militar, mandou hastear a bandeira da União Soviética, cujo embaixador e amigo pessoal André Formim, era convidado especial (...). (Montandon, 2004, p. 124)

Bem, de qualquer forma, Leonardos deu a Beja em seu livro o lugar que, segundo ele, a personagem ocupou em vida e, também, ao que nos parece, foi o responsável em garantir para ela o espaço necessário, um museu, para que se transformasse em personagem inesquecível. Voltemos, então, ao seu livro e à "Dona Beija".

Apesar do sucesso, dez anos se passaram sem a presença da "feiticeira do Araxá" nas prateleiras das livrarias, até que tema e personagem foram escolhidos pela Escola de Samba Acadêmicos do Salgueiro, que os usou em seu desfile do carnaval de 1968, ao qual, tão logo saiamos das páginas de Leonardos, nos juntaremos, para acompanhar na avenida, mais uma das façanhas de Beja.

"Dona Beija" vai para a avenida retratada pela alegoria carnavalesca e volta às prateleiras das livrarias em edição duplicada em números (10.000 exemplares), motivando ainda duas edições em quadrinhos (30.000 exemplares). Dessa versão, a feita em quadrinhos, disse Leonardos que o gênero resumiu e embelezou "o escrito com desenhos quadrinizados" (1986, p. 25). Quanto ao sucesso, o de vendas e o de divulgação do Leonardos escritor e de sua personagem, é possível conjeturar que se deveu ao fato de terem sido destacadas da trama, as cenas possíveis de serem traçadas com sensualidade e erotismo, ingredientes certos para resultados como esse, considerando-se o tempo em que se deu o fato.

Falamos dos desígnios do mercado editorial e, no entanto, passaram-se outros tantos anos marcados pela ausência de nossa personagem. Não fosse a telenovela e, talvez, ainda 
hoje, não tivéssemos outras edições nem da "Dona Beija" de Leonardos, nem da "Dona Bêja" de Vasconcelos.

Em 1986, a Editora Record lançou a terceira edição do livro de Leonardos, Dona Beija: a feiticeira do Araxá "estimulada pelo fato de a TV Manchete estar apresentando a novela Dona Beija, seguindo o roteiro traçado por Wilson Aguiar Filho, roteiro esse inspirado neste livro e no de Agripa Vasconcelos ( A Vida em Flor de Dona Bêja) (...)" (Leonardos, 1986, p. 25).

É da novela Dona Beija que trataremos no próximo capítulo.

Antes, porém, voltemos a 1968 e ao desfile da Escola de Samba Acadêmicos do Salgueiro.

\section{CARNAVAL}

Corria o ano de 1967. Thomas Leonardos era o presidente da Ordem dos Advogados do Brasil e Carlos Mafra de Laet era o secretário da Secretaria Estadual de Turismo do Rio de Janeiro. Anteriormente, em 1958, Laet lera Dona Beija - a feiticeira do Araxá, o romance de Leonardos, quando encarregado da coluna de crítica literária do jornal Última Hora, tecendo elogios à obra e seu autor na edição de 22 de novembro.

Talvez, Laet não tenha mais se esquecido de Dona Beija.

Não se tratava de ter ou não gostado do romance de Leonardos, pois quanto a isso não nos resta dúvidas. Leonardos, a propósito da crônica elogiosa do amigo, a qual, segundo ele, poderia ser atribuída à velha amizade que os ligava, escreveu: “(...) em verdade Laet gostara mesmo do livro e quando nos encontrávamos a ele sempre se referia com entusiasmo" (Leonardos, 1968, p. 20).

O certo é que história e personagem foram lembradas por Laet quando se viu às voltas com a necessidade de auxiliar Fernando Pamplona, do Grêmio Recreativo Escola de Samba do Salgueiro, na sua busca por uma motivação para o carnaval de 1968.

Laet procurou Leonardos e encaminhou autor e livro para Pamplona. Leitura feita e história aprovada por Pamplona e também por Osmar Valença, presidente do Salgueiro, que apostavam nos enredos sobre personagens históricas femininas (Xica da Silva levara o Salgueiro ao primeiro lugar, em 1963), Dona Beija - a feiticeira do Araxá passa à linguagem carnavalesca, no enredo desenvolvido por Pamplona. 
Nos versos do samba-enredo composto por Aurinho da Ilha (nome artístico de Áureo de Souza Campagnhac), escolhido entre os muitos apresentados pela ala dos compositores do Salgueiro (em 1968, tal ala tinha 39 componentes), Dona Beja, personagem do romance de Leonardos foi assim representada:

Certa jovem linda, divinal, seduziu com seus encantos de menina o Ouvidor Geral Levada a trocar de roupagem numa nova linhagem ela foi debutar $\mathrm{Na}$ Corte, fascinou toda a nobreza com seu porte de princesa e seu jeito singular. Ana Jacinta, rainha das flores dos grandes amores dos salões reais com seus encantos e suas influências supera as intrigas e os preconceitos sociais.

Era tão linda, tão meiga, tão bela ninguém mais formosa que ela no reino daquele Ouvidor

Ela com seus modos inteligentes fez um reinado diferente na corte de Araxá e nos devaneios da festa do Jatobá. Mas antes, com seu trejeito feiticeiro traz o Triângulo Mineiro de volta a Minas Gerais. E até o fim da vida Dona Beija ouviu falar e seu nome figurar na história de Araxá. ${ }^{63}$

O dia estava clareando na Avenida Presidente Vargas. Era 25 de fevereiro de 1968, domingo, e o espetáculo começara no início da noite. Por lá já haviam passado várias Escolas de Samba: Independentes do Leblon, Unidos de São Carlos, Unidos de Lucas, Unidos da Vila Isabel, Portela, Mangueira. Chegara a vez do Salgueiro.

Dona Beja, a Feiticeira de Araxá foi o tema. A escola se dividiu em 6 partes contando a história do rapto de Maria (sic) Jacinta pelo Ouvidor Real. O destaque principal estava na mulata Narcisa, seu corpo e sua graça. E nas irmãs Marinho. Os figurinos, no bom-gôsto de Fernando Pamplona, deram o toque luxuoso. (Costa, 1968)

\footnotetext{
${ }^{63}$ http://www.galeriadosamba.com.br.
} 
Beja foi o tema e Aurinho dela atualizou as dimensões política e social. Nos muitos papéis a ela destinados (vítima, sedutora, heroína), tratados com a liberdade própria do carnaval, Beja obedeceu às intenções expressas pela alegoria carnavalesca que a desejou linda, meiga e bela o suficiente para encantar o público da Avenida Presidente Vargas.

Além de Beja, um exército de coadjuvantes e figurantes, aproximadamente 2.500 pessoas participaram do espetáculo. Apenas na bateria, 400 ritmistas se encarregaram do desenvolvimento rítmico da trilha e de sua força de persuasão, fazendo com que o samba Dona Beja "caísse no domínio público".

Isabel Valença interpretou Beja. Trazia para o papel a experiência de ter vivido Chica da Silva (1963), sua estréia e consagração como destaque de escolas de samba, e ainda os requisitos necessários para os padrões de representação que envolvem o palco carnavalesco.

Nele, a montagem dessa grande festa popular é feita com recursos como a coreografia e o aparato cênico, bases para as criações apoteóticas que se realizam na passagem pela avenida. Ao final, além das matérias do dia seguinte, o esquecimento.

Deixamos a avenida, mas não a impressão de vazio com que nela entramos ao iniciar a pesquisa sobre o carnaval de 1968.

Estivemos no Grêmio Recreativo Escola de Samba do Salgueiro no Rio de Janeiro e fomos surpreendidos pela falta de qualquer indício providencial que nos encaminhasse na busca da história de Beja contada pelo Salgueiro. Segundo informações recebidas no local deveríamos procurar o "Centro de Memória do Carnaval", templo da memória carnavalesca, montado na Avenida Rio Branco, $\mathrm{n}^{\mathrm{o}} 4,2^{\circ}$ andar, também no Rio, pois, certamente encontraríamos lá o que procurávamos.

Assim o fizemos. Após sermos encaminhados para a pessoa "certa" e de passar a ela nossos propósitos fomos surpreendidos com a resposta: "1968? Faz muito tempo, eu não era nem nascido. E, não há nada aqui desse tempo.” Depois de constatarmos o fato tivemos de nos contentar com as matérias do dia seguinte, encontradas na Revista $O$ Cruzeiro em números publicados antes e depois da realização do desfile do carnaval de 1968. Uma reportagem especial de Haroldo Costa para um anexo, também em 68, trouxe em capítulos a história das escolas de samba, denominado Roteiro das Escolas de Samba, sendo o de $\mathrm{n}^{\circ}$. IV, o que utilizamos para acompanhar Beja e o Grêmio Recreativo Escola de Samba do Salgueiro.

Resta a questão: Como ficou a personagem real em sua tradução para a personagem real de televisão? 


\section{DONA BEIJA: personagem real de televisão}

Ao organizar os elementos ficcionais, o autor está comunicando ao público seu ponto de vista sobre determinados temas, além de simplesmente contar uma história.

Renata Pallottini 
Transcorria o ano de 1986. Vinte e dois anos já passados desde a morte de Totinha que com ela levou a história de Beja. Ao menos a que contava oralmente, tradução da que ouvira de sua mãe Haydée que, em seu tempo, ouvira e traduzira o que contara sua mãe Joana e sua avó Beja.

Como fio condutor dessas vozes e memórias femininas ouviu-se, em movimento contínuo, o rumorejar do rio Bagagem, compondo a trilha sonora do drama representado, o da vida de Beja, montado de acordo com as possibilidades cênicas de que dispunham as narradoras, cada uma em seu tempo.

O rio Bagagem lá continuava, sem o brilho dos diamantes, assim como a cidade, Estrela do Sul, pequena e acanhada diante da sua incapacidade de crescer e prosperar.

Da memória de Beja o rio se encarregara de dissolver, em suas cheias, o que dela havia de concreto: a ponte que ela mandara construir sobre o rio em $1870,{ }^{64}$ e a casa ${ }^{65}$ em que morara desde sua vinda para Bagagem, situada na Rua da Ladeira, no. $3,{ }^{66}$ da qual ainda podemos ver os alicerces fincados no solo arenoso, como sentinelas resistentes à ação do tempo.

Dos que de Beja se lembravam, descendentes ou não, muitos já haviam abandonado a cidade e se dispersado por outras localidades mais prósperas, situadas no Triângulo Mineiro e em Goiás, sendo que grande parte viu-se tragada pela construção de Brasília na segunda metade dos anos de 1950 .

No que se refere aos já poucos descendentes, a maioria não se manifestava sobre Beja e o assunto era, de certa forma, incômodo e repelido com vigor ao se insinuar nas rodas de conversa: "A família não gostava de contar sobre a vida de cortesã da personagem a estranhos, principalmente aqueles interessados em saber da mulher ainda jovem e não idosa, penitente e devota", disse Maria de São Geraldo, tataraneta de Beja, que morava em Uberlândia-MG, por ocasião da exibição pela Rede Manchete, da novela Dona Beija. Acrescentou ainda que Joana, filha de Beja, "revelou muita coisa sobre a mãe, cujos segredos familiares foram passados apenas para os parentes mais próximos" (Rosa, 1997, p. 93).

Vê-se, portanto, que Dona Beja há muito estava desaparecida até mesmo da memória familiar e parecia gozar de merecido repouso, após tanto sucesso provocado pela sua história

\footnotetext{
${ }^{64}$ Beja financiou a construção da ponte sobre o rio Bagagem, ligando o porto dos Anjicos ao Cata-osso. A obra foi iniciada em 1870 e concluída em maio de 1871. Nesse mesmo ano, Beja pediu ressarcimento do valor gasto (495.680 réis) e, em 1873, Beja foi ressarcida pela Câmara Municipal da Bagagem (Rosa, 1999).

${ }^{65}$ Ver anexo 17.

${ }^{66}$ Clementino mandou construir essa casa por ocasião da mudança de Beja para a Bagagem e Beja nela morou por trinta anos (até sua morte). Na década de 1930 a casa foi levada pelas cheias do rio Bagagem e nunca mais foi reerguida, restando dela apenas escombros (Rosa, 1999).
} 
de vida. Tal situação, no entanto, inverte-se em 1986, quando sua trajetória de vida vai então ser contada, desta vez, pela televisão, que se dispôs a traduzir os romances, Dona Beija - A feiticeira do Araxá, de Thomas Leonardos e A Vida em Flor de Dona Bêja de Agripa Vasconcelos, visando reinventar tal trajetória.

Roger Chartier disse, a respeito da impossibilidade de separação entre as significações de um texto e as modalidades materiais com que é oferecido aos leitores, que "com efeito, cada forma, cada suporte, cada estrutura da transmissão e da recepção da escrita afeta profundamente os seus possíveis usos e interpretações" (Chartier apud Reimão, 2004, p. 17).

E, por assim pensarmos, nesse capítulo analisaremos a transposição feita, pela via da tradução cultural, da história oral e textual de Beja (já em parte por nós conhecida) para a história visual, a da televisão, em que a construção de sua personagem reveste-se dos significados próprios da especificidade da linguagem televisiva em seu tratamento voltado aos dramas de família e de época.

Antes da televisão, o drama da vida de Beja prestou-se com sucesso às investidas do gênero folhetinesco, uma das matrizes culturais da telenovela. Por ocasião da publicação da História de Araxá, em 1915, no jornal Correio de Araxá, conforme comentamos a propósito, tal sucesso seria resultado da habilidade dos autores, Sebastião de Afonseca e Silva e Clodion Cardoso, em associar a recuperação do passado, o da cidade de Araxá, com um enredo comovente próprio às abordagens feitas nos dramas de vida, aos quais se adequava perfeitamente a trajetória de Beja, rica em implicações sentimentais. ${ }^{67}$ Acrescentamos ainda, como fator relevante para o sucesso alcançado pelo Correio de Araxá, a estratégia editorial claramente folhetinesca adotada pelo jornal, ou seja, o fato da transmissão da história ocorrer em partes, formatada em espaço propício para ser recortada e guardada por quem assim desejasse, com direito a cartas de leitores e "ganchos" providenciais, retardamentos tais essenciais, como nos revela Montandon (2004): Um outro dado interessante foi a omissão deliberada do nome da heroína no
capítulo em que se contava o episódio do retorno do Triângulo Mineiro a
Minas Gerais, logo no início da História. O nome somente foi "revelado" na
segunda parte, com o objetivo, confessado por Sebastião de Afonseca em
suas notas pessoais, de prender a atenção do leitor e induzi-lo a seguir
comprando o jornal. Para ele, naquele momento da história ela já estava na
idade madura e promovendo a ruína dos fazendeiros abastados. (p. 98)

Dona Beja foi, assim, incorporada à temática do folhetim publicado pelo Correio de

\footnotetext{
${ }^{67}$ Conforme Capítulo I desta tese.
} 
Araxá, mostrando já nessa primeira aparição num veículo de comunicação, sua capacidade de adaptação ao gênero novelesco. Nele, é traduzida como anjo e demônio ao sabor da criatividade dos autores e seguindo o gosto dos leitores.

Percorrendo um caminho inverso ao originalmente destinado aos personagens de romances, muitos dos quais deixaram as páginas dos livros para ocupar os rodapés dos jornais, Beja passou destes às páginas dos romances de Agripa Vasconcelos, A Vida em Flor de Dona Bêja, e de Thomas Leonardos, Dona Beija - A feiticeira do Araxá, de onde foi transportada para a televisão.

Nesse sentido, entre as muitas telenovelas que nesse tempo, 1986, disputavam a atenção do público, a exibida pela TV Manchete, Dona Beija, representa, para nós, a principal instância de nosso estudo-pesquisa. Foi nela pensando que trilhamos os caminhos e descaminhos escolhidos para acompanhar o percurso da vida de Beja, partindo do papel da memória na atualização da história-personagem, analisada em sua construção e transfiguração cultural.

Sendo assim, vamos à telenovela.

Para entender a Beja apresentada pela televisão, partiremos daquelas matrizes culturais que se fizeram presentes em nossa história que, porventura, se coloquem na história da telenovela, facilitando, dessa forma, a aproximação com as circunstâncias da produção da novela, seu contexto e suas possibilidades culturalmente determinadas.

\section{BREVES INFORMAÇÕES SOBRE A TELENOVELA BRASILEIRA}

A telenovela há décadas se posiciona nas estatísticas de audiência, como o programa preferido pelos telespectadores. Ela transformou-se numa atração constante e imprescindível na televisão. Em suas origens, a novela, como se diz na televisão, representara uma narrativa fabulosa, um pouco inverossímil, recebendo somente no Romantismo a configuração literária mais contemporânea, própria de uma sociedade que se industrializava.

$\mathrm{Na}$ teoria literária houve certo empenho em delimitar a novela, tendo como referencial o seu tamanho, entre o romance (mais largo) e o conto (mais estreito). A novela, porém, nunca de fato se enquadrou inteiramente na forma estabelecida pelos estudos literários, já que esses não consideram muito a sua extensão e dimensão. Examine-se, por exemplo, a relação entre extensão - dimensão e a natureza do tema em novelas consagradas como Bola de Sebo, de Guy de Maupassant, e A Morte de Ivan Ilitch, de Leon Tolstói. Na primeira, desenvolve-se 
a honra pessoal e nacional, enquanto na segunda consagra-se a grandeza da morte ante a estreiteza do cotidiano, tema mais amplo e abstrato do que o outro. Naturalmente, a indefinição da forma novela acabou levando à sua ampliação, com acréscimos capazes de torná-la quase interminável.

Como modelo de narrativa exibida pela televisão brasileira, a telenovela compõe-se através de imagens, figurinos, diálogos, cenários, imitações e ações, servindo-se de conflitos cotidianos e transcendentais, rasteiros ou altamente éticos, mas em geral subordinados à vida humana. Além disso, utiliza-se de personagens (às vezes agrupados) e de variados espaços de ação, materializando-se em torno de 160, 180 a 200 capítulos de 45 minutos de ficção, envoltos em propaganda.

A narrativa seriada da televisão constitui um legado principalmente da literatura, de que são exemplos as cartas de Sóror Mariana do Alcoforado e as do jovem Werther, personagem de Wolfgang Goethe. Antes da televisão, o cinema tinha fabricado em 1913 o seriado, inventando uma alternativa no mercado de filmes. Além dos filmes curtos, os filmes seriados, que tinham longa duração, adaptavam-se tanto às pequenas e desconfortáveis salas onde eram exibidos os filmes curtos, como também às de maior tamanho destinadas aos longas-metragens.

Em geral, a telenovela brasileira é produzida e gravada antes de ser inteiramente redigida, subordinando-se, assim, ao critério do público e da crítica, alterando-se até mesmo no seu roteiro prévio. As palavras da atriz Fernanda Montenegro, ao tratar do ofício do ator na televisão, bem sintetizam o trabalho em novelas, minisséries, teledramas e outros formatos ligados à teleficção: "Os meios eletrônicos aprisionaram o jogo dramático" (Távola, 1984, p. 13). Mas essas condições não excluem a criação artística no desempenho do ator e na dramaturgia de televisão, ainda que um bom produto, no critério da produção, nem sempre seja um bom produto artístico.

Ciro Marcondes Filho (1988), escrevendo a respeito da telenovela, esclarece:

Quanto à linguagem, a produção de telenovelas, por economia, corta, cancela, descarta cenas intermediárias, mantendo apenas os momentos-chave de alta significação. (...) A TV tem pressa. A paixão não pode gastar mais de quatro ou cinco cenas, pois é preciso economizar espaço. Ela trabalha então com ações e cenas que sejam facilmente interpretadas e rapidamente decodificadas pelo telespectador. (...) a telenovela, observada pelo ângulo de sua estrutura de produção, usa a dramaturgia do palco mas não realiza um evento de caráter teatral. (p. 61-63) 
O trecho acima talvez nos ofereça um pouco do sentido do aprisionamento do jogo dramático, no caso da telenovela quando nos diz que nessa tudo pode, segundo o discernimento da produção, ser economizado, mediante a manipulação da linguagem. Até mesmo os momentos-chave terminam por transfigurar-se sob a câmera, que é uma narradora onipresente, um olho que segue o personagem, nos detalha o cenário, dando-lhes vivacidade e fascínio.

Constata-se, assim, a participação intensa da câmera na realização da telenovela, a ponto de ela, diferentemente do que se dá no teatro, ser a intermediária entre as intenções iniciais dos autores da telenovela e os resultados captados pelos telespectadores. Até o desejo de cada diretor imprimir certo estilo próprio à sua telenovela, em geral, quase não se efetiva no domínio da câmera. Afinal, o campo restrito da tela delimita, tecnicamente, o universo telenovelístico.

Neste universo, que também é o da dramaturgia de televisão caracterizada por inovações que dizem respeito tanto aos diálogos, como à interpretação e aos outros aspectos ligados à encenação e direção, podemos encontrar traços próprios da herança teatral. Entre eles, os que dizem respeito à estrutura narrativa, com seus capítulos divididos em blocos e os blocos em cenas, além de considerar como base para a interpretação do personagem, sua caracterização psicológica.

A propósito dos diálogos, não é exagero dizer que na telenovela encontra-se uma doação do rádio, pois ela se funda também na palavra e no discurso oral. Enquanto os técnicos avançam com os instrumentos gráficos dos computadores, a oralidade na televisão mantémse, administrando as palavras e a eloqüência nos momentos mais significativos da programação televisiva, empenhando-se, através da veiculação de uma decodificação rápida, à intelecção do telespectador.

Tem sido destacado nos escritos a respeito da telenovela o fato de sua redundância, que a distingue do gênero clássico da novela. Se isso realmente acontece, a telenovela aproxima-se claramente do folhetim, no qual a redundância pode ser utilizada para manter a atenção do leitor ou do telespectador, aumentando ou diminuindo a tensão ou a emoção da narrativa, assim como marcando momentos e personagens. O folhetim, em si mesmo, deve repetir assuntos e cenas em diferentes focos narrativos, agregando outras informações e personagens, glosando sempre o seu "leitmotiv", como aliás fazia magistralmente Eugène Sue.

Xavier de Montépin esclarece a respeito da necessidade premente de interessar o leitor na trama do folhetim e exibe suas dificuldades: 
É impossível para o leitor que passa seu olhar indiferente pelas colunas de um folhetim, ou que folheia maquinalmente um livro, interrompendo a leitura do jornal ou fechando o livro quando se enfada, é impossível compreender os muitos escolhos em que, em dados momentos, tropeça quem escreve uma novela, tal como agora nos acontece, quando devemos caminhar com um passo firme, evitando cair num intrincado labirinto, e simultâneos acontecimentos, a fim de que se não perca o interesse; juro-vos, leitores frívolos de um frívolo livro, que é uma missão muito difícil, e supera muitas vezes as nossas forças. Entretanto, envidaremos esforços para a realizar da melhor forma possível. (Meyer, 1996, p. 241)

A produção de um folhetim ou de uma novela, em muitas circunstâncias, exige certa audácia, isso de modo responsável ou não. Esta audácia permite trazer ao leitor ou ao telespectador uma novidade, o que acarreta a possibilidade do sucesso. Há sempre o meio de se chegar ao grotesco, embora indesejado e imprevisto pelo autor. Enfim, com a audácia pode-se fazer tudo.

Na telenovela Dona Beija existe a cena da Lady Godiva. Beja, a "Vênus do Sertão", transfigurada em descendente de anglo-saxões, patrona das artes e excelente amazona, heroína popular por seu protesto a nu contra os impostos. Lady Godiva, nascida por volta de 1040, casada com um político que cobrava impostos até de estrume vendido e usado nos campos, converte-se em Dona Beija. A similitude entre ambas advém da proverbial beleza cantada por seus contemporâneos? Ou, a similitude nasce do desejo de levar às massas o belo e a arte?

O certo é que em 31 de maio de 1057, conforme nos conta Roger of Wendover em sua Crônica, Lady Godiva atravessa, a cavalo, o mercado de Conventry, ao meio-dia, acompanhada por duas criadas vestidas normalmente, uma de cada lado da dama. Mantinha a postura de sempre, sem qualquer jóia ou ornamento, porém apenas com seu longo cabelo escondendo-lhe o corpo. O cronista afirma que Lady Godiva se apresentava tão decente, relaxada e confiante, que ninguém desconfiara que estava despida sob os cabelos.

Ora, audácia não impõe cópia ou total semelhança. Dona Beija surge cavalgando nua sobre um cavalo branco, ou nua tomando banho em cachoeira, gerando uma série de lendas a respeito de sua beleza, saúde e juventude. Portanto, Lady Godiva pôde ser traduzida na televisão, pela ação de Dona Beija, apesar da causa generosa e popular de uma e da causa individual, de prestígio social, de outra ${ }^{68}$.

"Por sorte, essa audácia existe. E é por conta dela que ainda podemos imaginar o futuro da telenovela como alguma coisa que vá além do mero entretenimento" (Pallottini, 1998, p. 38).

\footnotetext{
${ }^{68}$ Ver anexo 18.
} 
De qualquer forma, a audácia da telenovela Dona Beija guarda e testa a memória de uma Lady Godiva.

Os registros sobre a telenovela Dona Beija, de autoria de Wilson Aguiar Filho, em 1986, indicam que com ela a Rede Manchete pôde demonstrar sobejamente seu prestígio como produtora de novelas. Consideram ainda tais registros que a direção de Herval Rossano utilizou o texto de Wilson Aguiar Filho para expor, com riqueza plástica, a nudez de Maitê Proença, fortalecendo a posição da Manchete no mercado de telenovelas.

A mesma Rede Manchete, depois de Dona Beija, já nos anos de 1990, ampliou sua atuação na produção de telenovelas, com o novo estilo exibido em Pantanal. Abria-se, assim, um espaço nas telenovelas para a adoção de cenas lentas e panorâmicas, menos diálogos e mais cenas externas, penetrando nelas as belezas da natureza.

A partir de uma perspectiva mais ampla, pode-se dizer que a telenovela no Brasil conta uma história por imagens, com diálogo e ação, um assunto principal e outros assuntos, planejados para serem de menor grandeza, como se fosse um contador de histórias a falar de suas experiências. Criando um segredo a cada dia para ser revelado em outro dia, como o contador de histórias (Totinha), a telenovela revigora a curiosidade do telespectador por meio do suspense, ou do gancho. Vê-se, portanto, que a telenovela consiste num produto cultural com andamento próprio, algo parecido com o andamento no cinema. Porém, o andamento da telenovela está diretamente relacionado com a curiosidade do telespectador e com a mobilização do público, sobretudo por causa de sua longa duração.

Leon Tolstói, no ensaio $O$ que é a arte?, expõe o seu entendimento a respeito da obra artística, estabelecendo uma certa orientação para ela. A telenovela não precisa segui-la rigorosamente, mas não custa lembrar suas idéias.

Para Tolstói, a arte deve fundar-se na capacidade de contagiar:

$\mathrm{O}$ traço que distingue a arte verdadeira da falsa é indiscutivelmente a capacidade que a arte tem de contagiar. Se um homem, sem que haja nenhuma atividade de sua parte e nenhuma alteração na sua situação, experimentar, ao ler, ver, ouvir a obra de outro homem, um estado de espírito que o una a este homem e a outros que estejam, como ele, percebendo uma obra de arte, a que for responsável por esta situação é uma obra de arte. (...) A obra de arte verdadeira anula na consciência de quem a percebe a distância entre ele mesmo e o artista, e não somente entre ele mesmo e o artista, mas ainda entre ele mesmo e todos os homens que percebem essa obra de arte. (...) Mas o poder de contagiar não é somente o traço incontestável da arte: o grau desse poder é o único critério do valor da arte. Quanto maior for o seu poder de transmissão, maior será a qualidade artística da obra, sem levar em conta seu conteúdo, isto é, 
qualquer que seja o valor dos sentimentos que ela expressa. (Tolstói, 1991, p. 180-181. Grifos do autor)

Nesse sentido, mesmo com suas peculiaridades, o folhetim e a telenovela têm condições de envolver leitor e telespectador de acordo com os parâmetros tolstoianos. A telenovela, em particular, possui variados meios de conquistar o público, como a presença física do personagem e do ator, com seus nomes e sobrenomes, suas falas, atitudes e ações, em que uns esclarecem a existência dos outros. A imagem, vista pelo público, irrompe na tela já selecionada pela equipe de produção, no ângulo já escolhido e da forma como essa pretende.

Além disso, a imagem televisiva vem mais solta, sem limites nas ações, no tempo e no espaço, concentrando-se na força da cena e em sua competência para atingir a atenção máxima do telespectador. $\mathrm{Na}$ imagem, a forma predomina sobre o conteúdo, e como observa Tolstói, "quanto maior for o seu poder de transmissão, maior será a qualidade artística da obra, sem levar em conta seu conteúdo".

O imperativo da cena, por sua vez, acha-se no paroxismo da sensibilidade do público e no encantamento de sua curiosidade, de tal maneira que a imagem do momento é o particular e o todo ao mesmo tempo. Na cena, dentre outros recursos, o personagem pode ser fixado por um tema musical, como Richard Wagner já instituíra com sucesso em seus dramas musicais, fato que o cinema registrou de forma característica em sua memória, assim como foi tido como modelo incorporado à estrutura da telenovela.

Dessa maneira, os telenovelistas descobriram que a trilha sonora representa um fator de sucesso público para as tramas novelísticas, enredando os ouvintes através dela com seu poder de sugestão, densidade sonora e variedades timbrísticas. Em 1965, a televisão Tupi lançou o primeiro disco com música de novelas, pois cada uma delas ainda não tinha uma trilha sonora com várias músicas. Com o tempo, as trilhas sonoras, como produtos derivados da exibição das telenovelas, garantiram um mercado muito promissor em termos econômicos, mercadológicos e culturais.

No caso da telenovela Dona Beija de 1986, compôs-se até uma música de abertura da novela, denominada "Tema de Dona Beija", assemelhando-se ao "Tema de Lara" que antes assinalou Redenção, apresentada na Televisão Excelsior com 596 capítulos, entre 1966 e 1968.

Já é possível apreender até então que, em tese, as cenas e os capítulos na telenovela carregam o material dramático criado pelo autor para uma história longa e seriada, cabendo- 
lhe ainda a organização deste material, a fim de que ele possa ocupar todo o tempo de duração da telenovela. Além do mais, em tese igualmente, a telenovela em sua totalidade contém nas cenas e capítulos amplo projeto de expectativa e entretenimento a ser alcançado por intermédio das técnicas da televisão.

Que nos diga acerca desse assunto uma das maiores autoras da televisão brasileira, Janete Clair:

Eu acho que entendo um pouco da psicologia do povo, eu sei o que o povo gosta de ver, o que ele gostaria de sentir naquele momento: é uma emoção de alegria, é uma emoção de tristeza, é uma emoção de drama. Então, eu acho que você sabendo dosar isso é quase que... não digo que seja uma fórmula para atingir o sucesso, mas é uma maneira de se atingir o grande público. É uma comunicação, assim, de gente pra gente, de emoção pra emoção: eu acho que é isso, não pode ser outra coisa. Eu não estudei pra isso, é uma intuição, um sexto sentido. (Alencar, 2004, p. 95)

Não vamos propor que haja na cena um simulacro da realidade, porque a realidade em si nos alcança pelas representações, de origens e naturezas diferentes, nas quais a obra de arte, como representação, pode significar a obra-prima. Mas a cena à maneira do melodrama, dá vitalidade às emoções, favorece a impressão sensorial, concentra-se na sentimentalidade, podendo com isto ter energia para durar, na televisão, o tempo desejado pelos desígnios da produção. Tais desígnios não gozam de muita liberdade.

$\mathrm{Na}$ telenovela o imprescindível está dentro dela e fora dela. A mensagem comercial controla igualmente a cena; por isto, a tensão é limitada, não pode haver solução definitiva para ela. Estando a telenovela fora de si mesma, isto é, no intervalo comercial ou naquilo que foi incrustado na cena, seus mais distintos apelos à atenção do telespectador (medos, sentimentos e emoções) encontram-se apropriados e instrumentalizados mercadologicamente, visando a venda de mercadorias e a acumulação de lucros.

A publicidade estabelece normas de identificação e valorização social, gera modelos a serem seguidos, aliás à semelhança do que ocorre no cinema, na revista de moda, nos suplementos jornalísticos, etc. Além disso, a publicidade reforça as necessidades de interesse da indústria, podendo-se dizer que, de fato, ela organiza as necessidades da sociedade.

A telenovela, portanto, transfere valores ao público, e isto ficará evidente em Dona Beija, no momento em que ela será adiante estudada. Pode-se, no entanto, adiantar que Beja, em sua tradução televisiva, surge como a única mulher bela, sensual, poderosa, atraente, arguta e modelar, digna de ser vista e admirada como figura histórica feminina. Como anota 
Artur da Távola: "Será necessário ir a Kant ou basta olhar para a Maitê Proença?" (Távola, 1984, p. 291).

Ainda nesse sentido, se é verdade que a publicidade pode eliminar o sexo das pessoas, impessoalizando-as e convertendo seus desejos em imagens, idéias e objetos, estamos longe de considerar o público uma entidade passiva que aceita tudo. Isto é verdade ainda quando este público é fiscalizado por agências de publicidade, dividido em classes A, B, C, D, E, recebendo o programa adequado ao horário, conforme avaliações constantes.

Sabe-se, então, que a telenovela é uma mercadoria cultural, resultado de processo industrial e subordinada a leis de mercado. No entanto, é fato também, que ela pode ser desvalorizada pelo público, como produto final, em casos eventuais de excessivo apelo visando um possível aumento de audiência. A fórmula para evitar tal situação parece ter sido dada por Janete Clair: "sem doses exageradas de nenhum dos ingredientes" (Alencar, 2004, p. 71).

Assim, o público, e o público de televisão, não são essencialmente irracionalistas, não se sujeitando a tudo que lhe é imposto e não se subordinando ao gosto e à intenção das emissoras. $\mathrm{O}$ público permite manobras, mas não exageradas.

O público analisa, aprecia, concorda ou discorda, utiliza sua memória, comprovando sua rejeição aos fundamentalismos de qualquer origem. Às vezes pode escolher mal, pode enganar-se em seus interesses, mas o tempo se cuida de demonstrar o contrário. Todavia, não se pode esquecer o reforço de idéias, de comportamentos e mesmo da ordem social, praticado na televisão e na telenovela.

Diante de tudo isso, cabe perguntar: a fórmula telenovelística não cansará de se adaptar às mudanças do país?

\section{POR FIM, A SÓS COM A NOVELA DONA BEIJA}

\section{Descrição da telenovela}

Nosso propósito é examinar a telenovela Dona Beija, baseando-nos, para tanto, na exposição precedente. A telenovela foi exibida pela Rede Manchete nos seguintes períodos: de 07 de abril a 11 de julho de 1986, no horário das 21h30, contendo 89 capítulos; em reprises: de 09 de Maio a 20 de Agosto de 1988, em 89 capítulos, e de 05 de outubro de 1992 a 11 de março de 1993, com 102 capítulos. 


\section{Ficha técnica}

A telenovela foi redigida por Wilson Aguiar Filho, com a colaboração de Carlos Heitor Cony, a partir de adaptação dos romances Dona Beija - a feiticeira de Araxá, de Thomas Leonardos e A Vida em Flor de Dona Bêja, de Agripa Vasconcelos. Foi dirigida por Herval Rossano e David Grimberg, com direção geral de Herval Rossano.

Wilson Aguiar Filho teve vida breve. Nasceu no Rio de Janeiro (1952-1992), formouse em jornalismo, foi repórter e escreveu histórias em quadrinhos para a Rio Gráfica Editora. Teve sua primeira experiência na Televisão em 1978, portanto com 26 anos, juntamente com Luiz Fernando Veríssimo e Juarez Machado, no seriado Kika e Xuxu, estrelado por Clarice Piovesan e Stênio Garcia.

Aguiar Filho foi autor das telenovelas a seguir: Memórias de Amor (1979), Marina (1980), O Amor é Nosso (parcial-1981), Os Imigrantes (parcial-1982), Os Imigrantes Terceira Geração (em co-autoria com Renata Pallottini - 1982), Maçã do Amor (1983), Marquesa de Santos (1984), Dona Beija (1986), Olho por Olho (1988) e Kananga do Japão (1989). A telenovela Dona Beija foi o seu maior sucesso.

Já Herval Rossano nasceu em Campos - RJ (1929 ou 1935), foi ator de teatro e de cinema e foi o diretor brasileiro de televisão com maior número de telenovelas vendidas para o exterior, isso justamente devido ao sucesso de suas telenovelas de época. Comentando as alterações na televisão brasileira, Rossano diz:

\footnotetext{
Se você me perguntasse o que mais mudou na televisão brasileira ao longo dos meus anos de carreira, eu diria que foi o conteúdo dos programas. Depois de tantos anos de censura nos deslumbramos com a liberdade e "abrimos" demais. Dizem até que fui o responsável por isto, quando fiz a novela "Dona Beija", na TV Manchete. Eu não concordo porque a fiz com muita ingenuidade, expondo o nu com uma certa inocência. Depois acabou ficando meio "sacana" mesmo. E isso é muito perigoso porque a televisão é um veículo invasor da casa das pessoas. E nem todo mundo pode ou quer assistir a determinadas coisas. Sou a favor da ética, respeito o próximo e exijo que me respeitem... (Rossano, 2007)
}

A propósito dessa mesma opinião, Herval Rossano reafirma em outra oportunidade: "Com a abertura, acabamos extrapolando. Eu, por exemplo, fui o primeiro a colocar a Maitê Proença nua em "Dona Beija". Falta agora encontrar o equilíbrio" (Rossano, 2007).

Na Rede Globo, Herval Rossano dirigiu novelas de época como Escrava Isaura, Cabocla, a Sucessora, Maria Maria e a Moreninha. Na Rede Manchete dirigiu a telenovela de época Dona Beija; na TV Record dirigiu a nova versão de Escrava Isaura; Paixões Proibidas na Rede Bandeirantes e Cristal no SBT. 
Iniciamos a ficha técnica com o autor, Wilson Aguiar Filho, e o diretor geral, Herval Rossano. Gostaríamos, no entanto, de mencionar o nome de todos os que compuseram a equipe de produção de Dona Beija, para que o grande espaço ocupado por seus nomes e funções nos dessem a dimensão do processo de criação de uma telenovela, mesmo que tal processo tenha no diretor-geral a sua figura central.

Por não termos esse registro, o qual seria suficiente para nossas pretensões, e por não ser nossa intenção reproduzirmos os complicados organogramas que, tal qual os de uma grande empresa, tem a função de demonstrar a composição de uma linha de produção, optamos por apenas mencionar alguns desses cargos-funções: diretor de produção, gerente de produção, coordenador de produção, assistente de produção, auxiliar de produção, continuísta, diretor, assistente de direção, produtor de elenco, diretor de imagem, diretor de fotografia, operador de câmera, editor, sonoplasta, produtor musical, produtor de arte, contra-regra de cena, figurinista, camareiro, costureira, maquiador, cabeleireiro, cenógrafo, cenotécnico, maquinista, eletricista, aderecista e pintor de arte, supervisor de engenharia, operador de vídeo/VT, operador de áudio, iluminador, entre outros. (Alencar, 2004)

Afinal de contas, o panorama desses cargos-funções ilustra bem a questão de autoria, sempre levantada quando se trata das telenovelas, e igualmente presente na adaptação da história de Beja para a televisão (uma produção em equipe) a partir dos romances históricos de Vasconcelos e de Leonardos (produções individuais). Embora designemos como autor Wilson Aguiar Filho, escritor do roteiro de Dona Beija, forma corrente na ficção seriada televisiva, não o fazemos de forma a relegar a participação "daquele que 'ilustra' as palavras com imagens em movimento", o diretor, no caso Herval Rossano. (Nogueira, 2002, p. 30)

É justamente a integração entre o autor e o diretor que permite discussões e alterações, as quais equilibram as intenções e a liberdade criativa, sendo tanto um como outro responsáveis por uma das fases de produção da telenovela, produto que terá seu resultado final sucesso ou fracasso - atrelado ao possível retorno comercial.

Caso consideremos o sucesso obtido pela Rede Manchete com a exibição de Dona Beija, "a novela que a essa altura perturbou a liderança da Rede Globo, e quase vende tanto para o exterior como A Escrava Isaura" (Rossano, 2007), podemos afirmar que autor e diretor realizaram um trabalho equilibrado que, supomos, permitiu ao autor atuar além do texto, acompanhando, juntamente com a direção, outras áreas da produção da novela. 


\section{Elenco}

Maitê Proença, Gracindo Júnior, Carlos Alberto, Bia Seidl, Marcelo Picchi, Abrahão Farc, Maria Fernanda, Mayara Magri, Edwin Luise, Sérgio Britto, Sérgio Mamberti, Arlete Salles, Lafayete Galvão, Marilu Bueno, Virgínia Campos, Jonas Mello, Maria Isabel de Lizandra, Jayme Periard, Fernando Eiras, Ary Coslov, Castro Gonzaga, Monah Delacy, Breno Bonin, Mário Cardoso, Renato Borghi, Isaac Bardavid, Angelito Mello, João Signorelli, Guilherme Karan, Elisa Fernandes, Roberto Orosco, Nina de Pádua, Jucélia Telles, Antônio Pitanga, Léa Garcia, Haroldo de Oliveira, Ivan de Almeida, Josias de Amon, Edson Silva, Renato Neves, Cláudia Freire, Ana Ramalho, Sandra Simon, Shulamity Yaari, Ademilton José, Ângela Rebello, Bia Sion, Jacqueline Laurence, Cleonir dos Santos, Edson Guimarães, Guilherme Corrêa, Leonardo José, Sílvia Buarque, Aldo César, Míriam Pires, Jorge Cherques, Xuxa Lopes, Tarcisio Filho, Odete Barros, Patrícia Bueno, Miguel Rosemberg, Hélio Ribeiro, Felipe Wagner, Arnaldo Weiss, Gisele Fróes, Jofre Soares, Ângela Leal, Camilo Bevilacqua, Hardoldo Botta, Cristiane Lavigne, Mariah da Penha, Kadu Karneiro, Juliana Prado, Zeny Pereira, Dill Costa, Sidney Marques, Cristovan Netto, Cláudio Doliane, Moacir Prinna, Marcus Vinícius, Dirceu Rebello, Ileana Saska, Jair Delamare, Marcelo Vecchi, Mário Gusmão, Sheila Matos, Henrique Nunes.

\section{Resumo}

O resumo da história é solicitado ao autor, ou autores, muitos meses antes da exibição da telenovela. Conhecido por "sinopse" (resumo da telenovela), deve apresentar os personagens, os conflitos principais, os cenários, as possíveis locações e, é claro, a trama vista pelo ponto de vista do autor, que deverá ressaltar os pontos, para ele, principais, com a clara intenção de despertar o interesse da emissora da qual dependerá a realização da novela.

Técnico, em função de seus objetivos, o texto da sinopse nem sempre é produzido pelo autor. Gilberto Braga falou de forma categórica sobre tal processo: "Faço a sinopse em grupo. Inclusive, eu odeio fazer sinopse, é um trabalho penoso, porque é muito técnico, não entra emoção" (Nogueira, 2002, p. 84).

No caso de Dona Beija, a sinopse foi escrita por Carlos Heitor Cony, sendo ele também o responsável pelo convite feito a Aguiar Filho para levar adiante o propósito de escrever o roteiro.

Da sinopse de Cony não encontramos rastros. Procurado, não nos pôde auxiliar. Passado algum tempo da nossa solicitação, fomos comunicados de que notas, sinopse, ou qualquer vestígio de Beja não foram encontrados nos arquivos do escritor. 
Diante de tal fato resta-nos, passados vinte anos da produção e exibição da telenovela Dona Beija, concordar com o que nos diz uma pesquisadora-professora sobre o que pensam os realizadores (produtores, autores, atores, enfim, a multidão de colaboradores que cercam o fazer telenovelístico): "os realizadores se admiram de que uma acadêmica bisbilhoteira queira conservar roteiros de produções que 'já foram ao ar' quase como a brincadeira infantil 'já foi ao ar perdeu o lugar"” (Balogh, 2002, p. 18).

Resta-nos também exibir aos nossos leitores um resumo da história televisual de nossa personagem, extraído de outras fontes, a fim de comprovar como a história da telenovela Dona Beija foi e é transfigurada em sua versão virtual, isso, por sua vez, acompanhando o gosto de seus aficcionados:

A trajetória corajosa de Ana Jacinta de São José, a Dona Beija (Maitê Proença), na cidade mineira de São Domingos do Araxá, no século XIX.

Amando Antônio Sampaio (Gracindo Júnior), homem de família conservadora e tradicional, Beija é vítima do desejo de Mota (Carlos Alberto), o ouvidor do rei em visita a Araxá. Depois de presenciar a morte de seu avô, Beija é raptada e levada à Vila de Paracatu, onde o ouvidor mora num belo casarão. Para vingar-se de seu algoz, enquanto ele está fora de casa, Beija serve aos homens que a desejam, em troca de jóias e ouro. Chamado pelo imperador a instalar-se na Corte, Mota deixa Beija, que a essa altura já juntara uma grande fortuna. Ela parte de volta a Araxá, para reencontrar sua antiga paixão, Antônio.

Mas Antônio já não espera mais por Beija. Desiludido e não compreendendo as atitudes de sua amada, ele casa-se com a doce Aninha (Bia Seidl), moça frágil e delicada que sempre o amou. Com a recusa de Antônio, Beija promete não amar a nenhum outro homem, e funda a Chácara do Jatobá, um refinado bordel onde ela se transforma num mito como cortesã, escandalizando todas as famílias conservadoras de Araxá. Na verdade, seu intuito maior era ferir Antônio.

A chácara prospera, Beija torna-se poderosa, envolve-se com João Carneiro (Marcelo Picchi), mas não consegue se desligar de Antônio, o homem de sua vida. Uma noite, movido pela embriaguez, Antônio invadiu a Chácara do Jatobá e Beija terminou por escolhê-lo, dormiu com ele, engravidou e deu luz a uma menina. Contudo, Antônio jamais abandonou a sua esposa, Aninha. Há muito tempo, o pai de Antônio, revoltado com o caso amoroso entre o seu filho e Dona Beija, adoecera e, antes de morrer, pediu-lhe para que casasse com Aninha. A vontade do pai seria realizada, mas Aninha era infeliz, pois sabia que Antônio preferia Beija. Após a morte do pai, a mãe de Antônio cultivara um ódio profundo por Beija, pois sabia que esta era a causa dos desregramentos do filho. Antônio, não podendo aceitar o sucesso de Beija junto aos outros homens, desencoraja-se e abandona o trabalho na fazenda da família. A mãe de Antônio, um dia, deu um veneno a um dos escravos de Beija, para que este a matasse. Mas, querendo ter Beija nos braços, o escravo mudou de idéia e lhe contou a verdade. Beija o aceitou na cama e ele salvou a sua vida. Em seguida, foi Beija quem ordenou para que matassem Antônio, mesmo ainda amando. Ela, por causa disso, foi à 
justiça, mas seria libertada com a ajuda dos seus fiéis amigos. Por fim, Beija decidiu partir de Araxá com a filha e, assim nasceu uma lenda. ${ }^{69}$

\section{Cenas-situação}

Não encontramos vestígios do roteiro de Aguiar Filho.

O roteiro ou, melhor dizendo, o seu desaparecimento, ocupou-nos um tempo precioso do prazo determinado para o doutorado.

Em qualquer estágio de nossa pesquisa, a impossibilidade de encontrar o roteiro parecia invalidar nossas melhores intenções. É claro que havia a possibilidade de decupar o material gravado, esse sim, já parte de nosso acervo e permanentemente consultado. Embora reduzido, restaria esta alternativa. A qualquer tempo, a necessidade se impunha e pesquisávamos mais arquivos, buscávamos pessoas que poderiam nos apresentar outras que, eventualmente, pudessem ter estado envolvidas com a produção da novela, outras mais que nela atuaram, indo dos famosos aos anônimos, isso, no entanto, sem resultado.

A pesquisa continuou. Vários caminhos foram apontados em seu desenrolar fazendo de Beja o elo entre nossas intenções e as determinações impostas pelos desvios, digamos históricos, tornando-se ela mesma o núcleo da ação desenvolvida em nossa história-pesquisa.

Aqui chegamos e, para nossa surpresa, a necessidade de encontrar o roteiro havia desaparecido num momento impreciso e vago do qual não nos demos conta. Por certo, fora substituída pela determinação tomada (após nos dedicarmos às imagens da telenovela Dona Beija) de estabelecer uma concepção estético-cultural decorrente da atualização feita de nossa personagem a partir da adaptação de sua história para a televisão.

Para tanto, buscamos na narrativa criativa de Totinha a forma como nessa ela singularizou sua personagem, valendo-se, para tanto, de situações que lhe pareceram decisivas para explicar suas atitudes, as quais, reunidas em blocos, nos deram um quadro das aproximações e variações significativas entre memória e história. Segundo Totinha, tivemos: Ana Jacintha; Beja e o Ouvidor; Beja e São Domingos de Araxá e Beja e a Bagagem, divisão essa resultante dos fatos selecionados por ela para compor a sua interpretação da vida de Beja.

Por sua vez, as cenas que recortamos da telenovela para compor o quadro motivador de nosso estudo (o qual se ocupará das especificidades da teledramaturgia no tratamento de um drama de época, em situações que nos permitam acompanhar parte da construção de Dona Beija) foram agrupadas nos seguintes blocos: Anos de Formação; Anos de Ouro; e Peregrinação à Bagagem.

\footnotetext{
${ }^{69} \mathrm{http} / / / \mathrm{www}$. teledramaturgia.com.
} 
A partir deste quadro motivador de nosso estudo, construído, no entanto, sem o tratamento técnico próprio dos roteiros das telenovelas (limitamo-nos ao visual, dispensando anotações técnicas e diálogos, mas deles guardando os traços necessários para nossos propósitos), vejamos Beja na televisão.

\section{ANOS DE FORMAÇÃO (cenas-situação: 01 a 53)}

\section{CENA 01 - SÃO DOMINGOS DE ARAXÁ - EXT. - DIA}

Em caravana formada por carros de boi, tropa de burros e escravos, Beija (bebê) vem acompanhada de sua mãe e avô. Param e ao longe avistam o arraial. O avô diz terem chegado ao fim da viagem.

CENA 02 - SÃO DOMINGOS DE ARAXÁ - EXT. - DIA

Movimento na praça demonstra progresso. No interior da Igreja vemos os personagens que comporão a história reunidos em grupos familiares: padre, juiz, fazendeiros, farmacêutico, representantes da coroa, entre outros.

Na saída da missa, as famílias de Beija e Antônio conversam mediadas pelo padre. No diálogo somos informados da simpatia que une as duas crianças e das intenções das famílias em uni-las no futuro.

CENA 03 - FONTE DA JUMENTA - EXT. - DIA

Beija (menina), acompanhada por uma escrava, se banha nua na fonte. Antônio (menino) observa. Atualização: Beija e Antônio tornam-se jovens.

\section{CENA 04 - CORTE DE D. JOÃO, PRÍNCIPE REGENTE - EXT. - DIA}

Jardins do palácio real no Rio de Janeiro. Breve apresentação da família real e de um grupo de cortesãos. Entre esses está o Ouvidor Dr. Joaquim Inácio Silveira da Mota, que anuncia sua próxima partida para Paracatu do Príncipe, na Capitania de Minas Gerais.

\section{CENA 05 - SÃO DOMINGOS DE ARAXÁ - EXT. - DIA}

$\mathrm{Na}$ praça central, um emissário da coroa comunica ao subdelegado e ao padre a próxima visita do Ouvidor, Dr. Joaquim Inácio Silveira da Mota.

CENA 06 - FAZENDA DA FAMÍLIA SAMPAIO - EXT. DIA

Antônio vai viajar a negócios e despede-se de sua noiva Beija. Anuncia que breve voltará e que logo se casarão. 
CENA 07 - SÃO DOMINGOS DE ARAXÁ - INT. - NOITE

Todos os moradores ilustres do arraial comparecem ao baile oferecido para o Ouvidor e sua comitiva. A beleza de Beija atrai a atenção do Ouvidor que a convida para dançar.

CENA 08 - CASA DO AVÔ DE BEIJA - INT. - NOITE

Rapto de Beija. A casa é invadida pelos homens da Guarda Militar do Ouvidor. O avô resiste e é morto. Beija é levada com violência.

CENA 09 - ARREDORES DO ARRAIAL - INT. - NOITE

Num casebre abandonado, Beija chora desconsolada. O Ouvidor entra e tenta seduzi-la sem sucesso.

CENA 10 - ARREDORES DO ARRAIAL - EXT. - NOITE

O Ouvidor dá ordens à sua comitiva. Partirão de imediato para Paracatu do Príncipe. Beija os acompanhará.

CENA 11 - CAMPO - EXT. - DIA

Antonio Sampaio e Vado, seu empregado, conversam. O noivo, saudoso, fala de Beija.

CENA 12 - PARACATU DO PRÍNCIPE - EXT. - DIA

Entrada do palácio da Ouvidoria. O ouvidor chega com sua comitiva e Beija, que é apresentada aos demais como sua noiva.

CENA 13 - SENZALA - EXT. - NOITE

Ouvidor chega em meio a um ritual de magia negra acompanhado de seu secretário, Sr. Juca. Beija continua a repeli-lo só restando a ele rogar aos deuses para que a façam mudar de idéia.

CENA 14 - OUVIDORIA - INT. - NOITE

Beija, em seu quarto, reza. Pede a Deus para que Antônio, ao saber do rapto, corra a resgatá-la.

CENA 15 - SÃO DOMINGOS DE ARAXÁ - SALA DO JUIZ - INT. - DIA

Grupo de autoridades, padre, juiz, promotor e o pai de Antônio Sampaio recebem notícias distorcidas de Paracatu: Beija está feliz ao lado do Ouvidor.

CENA 16 - PARACATU DO PRÍNCIPE - QUARTO DE BEIJA - INT. - NOITE

Ouvidor entra com Severina, a escrava que designou para acompanhar Beija, e conversa com Beija de forma amigável.

CENA 17 - SÃO DOMINGOS DE ARAXÁ - FAZENDA DA FAMÍLIA SAMPAIO - INT. DIA 
Na sala, o pai, a mãe e a irmã de Antônio comentam as notícias sobre Beija e decidem-se por sua condenação: ela tornou-se mulher do mundo e não se casará com Antônio.

CENA 18 - PARACATU DO PRÍNCIPE - QUARTO DE BEIJA - INT. - DIA

Visitam-na a esposa do Sr. Juca (secretário do Ouvidor) e o padre Melo Franco. Depois da saída da mulher, Beija fica a sós com o padre e intercede por sua liberdade. Quer voltar para São Domingos de Araxá e para seu grande amor, Antônio Sampaio.

CENA 19 - CAMPO - EXT. - DIA

Antônio e Vado conversam. Falam de Beija e das chuvas que não param de cair, dificultando a viagem de volta para São Domingos de Araxá.

CENA 20 - PARACATU DO PRÍNCIPE - SALA DE JANTAR - INT. - DIA

Beija desce para o almoço e é surpreendida pela presença dos escravos de seu avô (Flaviana e Moisés). O Ouvidor, para agradá-la, mandou buscá-los.

CENA 21 - PARACATU DO PRÍNCIPE - QUARTO DE BEIJA - INT. - DIA

Padre Melo Franco visita Beija. Pondera sobre a fatalidade que a vitimara e a encaminha para os braços do Ouvidor. Isso, não sem antes possuí-la, com o consentimento divino e o da virgem incauta.

CENA 22 - PARACATU DO PRÍNCIPE - SALÃO - INT. - DIA

Ouvidor aguarda a saída do padre Melo Franco que diz: "sua noiva o espera."

CENA 23 - PARACATU DO PRÍNCIPE - QUARTO DE BEIJA - INT. - DIA

Ouvidor entra e encontra Beija dócil e resignada. Sem mais palavras possuiu-a.

CENA 24 - PARACATU DO PRÍNCIPE - FAZENDA DO PADRE MELO FRANCO - EXT. DIA

Padre açoita cruelmente um escravo. É interrompido pela chegada do Ouvidor: Beija era sua. Porém, não fora o primeiro.

CENA 25 - SÃO DOMINGOS DE ARAXÁ - CENTRO - EXT. - DIA

Antônio regressa da viagem. Ele e seus empregados, todos a cavalo, irrompem pela praça do arraial.

CENA 26 - SÃO DOMINGOS DE ARAXÁ - TABERNA - INT. - DIA

Vespasiano (taberneiro) conta para Antônio sobre o rapto de Beija. Antônio fica transtornado.

CENA 27 - PARACATU DO PRÍNCIPE - IGREJA - INT. - DIA 
Beija assiste à missa acompanhada pelo Ouvidor. Todas as autoridades locais estão presentes. Padre Melo Franco dirige olhares apaixonados para Beija, olhares esses notados por muitos dos fiéis.

CENA 28 - SÃO DOMINGOS DE ARAXÁ - FAZENDA DA FAMÍLIA SAMPAIO - INT. DIA

Antônio entra na sala. A família confirma a notícia recebida por ele no arraial e trata de desencorajá-lo a tomar qualquer atitude para recuperar a noiva.

CENA 29 - PARACATU DO PRÍNCIPE - GABINETE DO OUVIDOR - INT. - DIA

Beija conversa com o secretário, Sr. Juca. Realiza pacto comercial: ele ganha com a ilegalidade mas, ela também.

CENA 30 - SÃO DOMINGOS DE ARAXÁ - CENTRO - EXT. - DIA

Confronto entre Antônio e seu pai, que não o deixa partir para Paracatu do Príncipe.

CENA 31 - PARACATU DO PRÍNCIPE - SALÃO - INT. - NOITE

Grande baile comemorativo (decreto Reino Unido). Beija confidencia a Severina que não é mais a mesma mulher.

CENA 32 - SÃO DOMINGOS DE ARAXÁ - FAZENDA DA FAMÍLIA SAMPAIO - INT. NOITE

Antônio está preso no porão. Relembra Beija na fonte. Vado tenta passar pela guarda montada pelo pai de Antônio, que preferiu prendê-lo a deixá-lo partir para Paracatu do Príncipe.

CENA 33 - PARACATU DO PRÍNCIPE - SALÃO - INT. - NOITE

Baile. Beija dança com o Ouvidor e atrai para si os olhares fascinados dos homens e os de inveja das mulheres.

CENA 34 - SÃO DOMINGOS DE ARAXÁ - FAZENDA DA FAMÍLIA SAMPAIO - PORÃO INT. - NOITE

Antônio relembra Beija (na fonte).

CENA 35 - PARACATU DO PRÍNCIPE - RITUAL NA SENZALA - EXT. - NOITE

Beija e Severina chegam e participam do ritual. Sob forte emoção, Beija amaldiçoa todos os homens que a tocarem.

CENA 36 - SÃO DOMINGOS DE ARAXÁ - FAZENDA DA FAMÍLIA SAMPAIO - PORÃO INT. - NOITE

Vado liberta Antônio.

CENA 37 - PARACATU DO PRÍNCIPE - RITUAL NA SENZALA - EXT. - NOITE

Escravos, dançando ao som dos tambores, circundam Beija e Severina. 
CENA 38 - CAMPO - EXT. - NOITE

Antônio galopa, acompanhado por seus empregados, em direção a Paracatu do Príncipe.

CENA 39 - SÃO DOMINGOS DE ARAXÁ - FAZENDA DA FAMÍLIA SAMPAIO - INT. NOITE

A fuga de Antônio é anunciada à sua família e seu pai ordena aos empregados que o tragam de volta.

CENA 40 - PARACATU DO PRÍNCIPE - EXT. - DIA

Em campo aberto, Beija cavalga em trajes de montaria. Encontra-se com o Sr. Juca (secretário do Ouvidor) e convida-o para sua cama.

CENA 41 - CAMPO - EXT. - NOITE

Antônio é interceptado pelos homens de seu pai. Depois de breve confronto, convence-os a segui-lo e a auxiliá-lo a resgatar Beija.

CENA 42 - PARACATU DO PRÍNCIPE - GABINETE DO OUVIDOR - INT. - DIA

Ouvidor é convencido por seus secretários a participar da festa popular que será realizada em breve.

CENA 43 - PARACATU DO PRÍNCIPE - EXT. - DIA

Festa popular realizada nas redondezas do arraial. Antônio chega com sua comitiva e observa o grande movimento. Beija chega acompanhada pelo Ouvidor, que solicita a cada instante que ela sorria para o povo, o povo gosta dela e precisa ser recompensado. Antonio acompanha arrasado todo o cerimonial e ouve comentários das pessoas que falam da felicidade de Beija, a noiva do Ouvidor. Antônio resolve voltar para casa. Beija não o vê.

CENA 44 - PARACATU DO PRÍNICIPE - EXT. - DIA

Antônio e seus homens tomam o caminho de volta para São Domingos de Araxá.

CENA 45 - PARACATU DO PRÍNCIPE - QUARTO DE BEIJA - INT. - DIA

Severina recebe pagamento de um rico comerciante, cliente de sua ama. Beija espera-o em sua cama e dispensa-o antes da chegada do Ouvidor.

CENA 46 - PARACATU DO PRÍNCIPE - OUVIDORIA - EXT. - DIA

Na porta da Ouvidoria o Ouvidor vê sair o desconhecido. Entra desconfiado.

CENA 47 - PARACATU DO PRÍNCIPE - QUARTO DE BEIJA - INT. - DIA

Beija está na cama e recebe o Ouvidor que a acusa de traição. Ela o convence de sua inocência. 
CENA 47 - SÃO DOMINGOS DE ARAXÁ - FAZENDA DA FAMÍLIA FELIZARDO - EXT. DIA

Antônio e Aninha namoram no jardim.

CENA 48 - PARACATU DO PRÍNCIPE - GABINETE DO OUVIDOR - INT. - DIA

Ouvidor escolhe soldados para sua guarda, sempre negros ou mulatos, motivo que os deixaria fora da cama de Beija. Ela chega e se diverte com os ciúmes do amante.

CENA 49 - SÃO DOMINGOS DE ARAXÁ - FAZENDA DA FAMÍlIA SAMPAIO - EXT. DIA

Antônio está triste e fala com Vado sobre Beija. Não consegue esquecê-la e grande é a dor por tê-la perdido.

CANA 50 - PARACATU DO PRÍNCIPE - SALA DE JANTAR - INT. - NOITE

Beija e o Ouvidor jantam a sós. Ele diz ter recebido carta da Corte. Deve voltar o quanto antes. Beija pede que a leve com ele no que não é atendida. Desespera-se e ataca-o com a faca, sem resultado.

CENA 51 - SÃO DOMINGOS DE ARAXÁ - CASA DA FAMÍLIA MENDONÇA - SALA INT. - DIA

Pai e mãe de João Mendonça, o jovem maestro Avelino, o advogado e sua esposa conversam sobre acontecimentos locais.

CENA 52 - PARACATU DO PRÍNCIPE - QUARTO DE BEIJA - INT. - NOITE

Beija e Severina conversam. Decidem voltar para São Domingos de Araxá.

CENA 53 - SÃO DOMINGOS DE ARAXÁ - FAZENDA DA FAMÍlIA FELIZARDO SALÃO - INT. - NOITE

Festa de noivado de Antônio e Aninha. Padre e famílias abençoam os noivos.

Terminada a exposição das cenas-situação que, segundo nosso critério narrativo, representam pontos essenciais na formação e transformação de Beja, decidimos fixar um ponto de partida para nossa abordagem da telenovela Dona Beija: o trabalho de adaptação de um texto literário para a narrativa audiovisual. A tarefa não é simples. O autor-tradutor selecionará os episódios significativos, de forma que o texto final televisivo resulte numa obra inteiriça, sem vestígios de cortes (inevitáveis em qualquer trabalho dessa natureza), o que exige criatividade, muita técnica e bom senso.

A Wilson Aguiar Filho, autor de Dona Beija, coube contar na linguagem e no ritmo da televisão, aquilo que Vasconcelos e Leonardos contaram em seus romances. Como veremos, há todo um arsenal de procedimentos utilizados nessa adaptação - tais como inversão da 
ordem dos fatos, valorização de personagens, acréscimos e omissões de passagens importantes, entre muitos outros -, que dependerão, em seu resultado, do adaptador e das intenções do produtor, as quais tanto poderão estar voltadas para a preservação de nossas tradições culturais, quanto para outros valores menos idealistas ou até meramente comerciais.

Ao final, mesmo que tenha mantido "fidelidade" ao texto original, o adaptador estará ainda sujeito ao desagrado dos que esperavam ver na televisão o que leram no livro. Esta observação pode parecer desnecessária mas, faz-se relevante na medida que a telenovela divulga uma obra adaptada levando muitos de seus espectadores à leitura ou releitura dos livros originais, provocando assim um fenômeno comercial no mundo editorial, que freqüentemente se vê às voltas com títulos esgotados e reedições sendo preparadas às pressas.

No caso de Dona Beija, a Editora Record tomou medidas preventivas, lançando a terceira edição do romance histórico de Leonardos, Dona Beija - A feiticeira do Araxá ${ }^{70}$, ao mesmo tempo em que a TV Manchete empenhava-se em aguerrida campanha publicitária em torno da exibição da telenovela. Na capa do livro, Maitê Proença, no papel de Dona Beija, substituiu "O Rapto das Filhas de Leucipo", quadro do pintor flamengo Rubens que ilustrou a capa da segunda edição do livro de Leonardos.

Leonardos (1986) nos contou no prefácio dessa edição, em 12 de Abril de 1986, ter sido tal publicação motivada pela apresentação da novela, que estreou em 11 de Abril do mesmo ano, assinalando:

Espero, pois, que os que assistirem à novela televisada e queiram formar juízo próprio sobre a vida e a conduta de Ana Jacinta de São José encontrem aqui, nestas razões romanceadas, motivo para absolver Dona Beija dos pecados que o império de circunstâncias adversas a fizeram cometer e para rejeitar aqueles que lhe foram maldosa e injustamente imputados. Não foi senão esse, o objetivo deste livro. (p. 26)

Enfim, para os que não conheciam a história de Beja, a telenovela se encarregou de contá-la. Certamente eram muitos, se considerarmos a supremacia do público televisivo em relação ao público leitor para o qual foram destinados, anteriormente, os livros publicados por Leonardos e por Vasconcelos.

Quanto ao livro ou quanto às intenções editoriais que cercaram sua reedição, tendo em vista a capa, assim como o que nos disse o autor no prefácio, e as alusões feitas na contracapa à telenovela, à Rede Manchete e ao "grande sucesso da televisão", podemos afirmar que a

\footnotetext{
${ }^{70}$ As datas das duas edições anteriores foram 1957 e 1971 respectivamente.
} 
terceira edição de Dona Beija - A feiticeira do Araxá, foi destinada aos telespectadores da novela.

Dessa forma, os nomes de livros e autores passam a fazer parte do repertório do grande público da televisão, o qual, por sua vez, passa a ser conduzido pela novela à leitura dos livros.

Da telenovela Dona Beija, podemos dizer que, montada de acordo com o que se considera a forma corrente e correta (respeitadas as tradições teatral e da televisão), manteve a atmosfera criada pelos romances, os quais lhe deram origem. Cuidando de não nos desviarmos das especificidades da tradução feita da história de Beja para a telenovela, é bom que tomemos por empréstimo a árvore utilizada por Pallottini (1998) ao explicar a estrutura da telenovela:

As raízes dão a base do trabalho do autor. É fundamental que o autor (ou autores) tenha uma visão de mundo, seja ela qual for, que transpareça na obra. O tronco é a garantia de uma unidade de ação, ainda que truncada, às vezes perdida no meio do caminho, para ser retomada depois. E os ramos são conseqüências da existência das raízes e do tronco. Esses ramos podem ser maiores ou menores; isso dependerá muito da escolha do assunto, dos personagens e até dos atores... (p. 59)

Wilson Aguiar Filho trouxe para as raízes da árvore de Dona Beija a desenvoltura dos autores habituados a lidar com histórias baseadas em romances históricos, (talento esse já demonstrado ao escrever Marquesa de Santos, ${ }^{71}$ minissérie exibida pela Manchete em 1984). Isso numa tentativa de ressuscitar o gênero, o qual após a bem sucedida apresentação de Escrava Isaura, dirigida por Herval Rossano para a Rede Globo em 1976, foi temporariamente arquivado. Portanto, Dona Beija ocupou com certa facilidade o espaço destinado às protagonistas femininas, que com suas histórias exemplares marcaram a história das telenovelas, aqui e no cenário televisivo internacional, como nos confirmam a Escrava Isaura e a própria Dona Beija.

Mesmo tratando-se de diferentes personalidades femininas, Marquesa de Santos e Beja parecem ter proporcionado ao autor, com suas histórias recheadas de entrechos amorosos, os recursos necessários para a construção das novelas, exemplos de qualidade da dramaturgia na televisão.

Esqueçamo-nos, porém, da Marquesa e fiquemos com Beja.

\footnotetext{
${ }^{71}$ Maitê Proença e Gracindo Jr. formaram o casal romântico, a Marquesa e D. Pedro I.
} 
A partir da sinopse de Cony, Aguiar Filho fez a transposição do drama de época ou histórico, para a sua obra televisual. Nela, nos parece, deu o justo peso às personagens, criando-os de forma a conduzirem, sem sobressalto, a história em seu tempo e seu espaço.

Por se tratar de uma novela de época, a produção da telenovela Dona Beija exigiu considerável pesquisa prévia, além de recursos técnicos adequados à necessidade de reproduzir o tempo representado. A propósito, a revista Veja de abril de 1986 registrou:

\begin{abstract}
Mesmo usando uma linguagem atual, a novela não perdeu o caráter de obra de época. A Manchete investiu 20 milhões de cruzados na produção de Dona Beija para fazer com que a novela tivesse cenários e figurinos condizentes com a paisagem brasileira do século passado. Foram gastos 3 milhões de cruzados só na constituição de uma cidade cenográfica em Santa Cruz, na zona rural do Rio de Janeiro, para fazer as vezes do Arraial de São Domingos dos Araxás, onde transcorre a novela. Com 8 mil metros quadrados, a cidade cenográfica abriga igreja, cemitério, pelourinho, um punhado de casas e até um aviário, com 300 galinhas, perus e patos. ${ }^{72}$
\end{abstract}

Por ocasião da exibição da novela as críticas recaíram sobre o pequeno número de figurantes, que circularia nos espaços públicos da cidade cenográfica, número esse muito inferior ao que representaria de forma adequada a população de São Domingos de Araxá. Apesar desse descompasso, os investimentos realizados pela Rede Manchete resultaram num produto de qualidade, no sentido do bom uso feito dos recursos expressivos próprios do meio televisivo, reproduzindo de forma convincente a atmosfera histórica necessária à reconstituição da história de Beja.

Ainda no que se refere à Dona Beija da televisão, pode-se dizer que a personagem de Aguiar Filho foi idealizada tal como fora as registrada pela história oral e escrita, traduzidas por Vasconcelos e Leonardos em seus romances. O autor conseguiu, mesmo sem investir sua personagem de um possível acréscimo permitido pela natureza da personalidade de Beja e pela liberdade criativa possível à sua arte e ao seu tempo, aproveitar o material disponível para contar, com sucesso, a sua história de Beja para além das fronteiras de Minas Gerais e do Brasil.

Em reportagem de Lilian Ben David, publicada pela revista Manchete de 05/04/1986, o autor conta que a personagem da telenovela Dona Beija era inspirada nos romances de Vasconcelos e Leonardos, mas imaginada "com traços de Marguerite Gauthier (a Dama das Camélias), de Lucrécia Bórgia, de Maria Antonieta e muitas outras" (David apud Leonardos, 1986, p. 26). Dada a impossibilidade de acompanhar o processo de criação de Aguiar Filho, já

\footnotetext{
${ }^{72}$ http://www.fortunecity.com/lavender/tomatoes/792/novelas/donabeija.htm
} 
que dele não temos registros escritos, arriscamos a hipótese de que as intenções do autor, ao imaginar Beija, se desfizeram nos traços das personagens dos romances brasileiros, o de Vasconcelos e o de Leonardos. São dessas personagens os traços reconhecidos por Cony no roteiro de Aguiar Filho: "para escrever o texto final da novela, Wilson decidiu mesclar pinceladas fortes de ódio e amor, bondade e dureza, instinto e educação, para compor a personagem" (David apud Leonardos, 1986, p. 26)

Tal qual Vasconcelos, de quem fica mais próximo ao traçar o perfil de sua personagem, Aguiar Filho o fez com linhas adequadas ao estilo melodramático, ora revelando vícios, ora virtudes de Beja. Tanto ela, como os demais personagens, ocuparam seus postos a partir de uma distribuição maniqueísta que, segundo Jean-Marie Thomasseau, "situa os bons na condição de quem se defende da perseguição desencadeada pelos maus. A energia mobilizada na perseguição e na defesa responde pelo dinamismo dramático da peça tanto quanto a afasta de elaborações mais complexas" (Thomasseau apud Huppes, 2000, p. 114).

Aguiar Filho, portanto, selecionou da vida de Beja episódios que, em sua exposição televisiva, permitiram contrapor bem e mal. Isso, no entanto, de forma a salientar o mal ou a maldade como força dramática expressiva no enredo sentimental que permeia as histórias contadas por Vasconcelos e Leonardos.

Em linhas gerais, podemos dizer que não houve mudança de tom significativa na transposição feita da história de época, a de Beja, para a televisão. As aproximações estruturais entre os romances e a telenovela foram mantidas, o que nos permite dirigir nossa atenção para as variações significativas, que serão assinaladas a medida que se interpuserem ao nosso olhar de telespectadores.

A novela Dona Beija mostra ação e rapidez em seu andamento, de modo que é em Beija que se concentra tal ação. Diálogos longos e monótonos, bem como cenas demoradas e explicativas, cedem lugar para o tratamento dado à narrativa planejada, inicialmente, para ser contada em 77 capítulos, diferentemente do padrão usual mais longo e com ritmo menos ágil. De imediato conhecemos Beija, recém-nascida, sua condição familiar, suas crenças e anseios, sua beleza incomum, sua vida afetiva e seu destino infeliz.

Voltemos, então, às cenas-situação. Já nas doze primeiras, podemos constatar alguns requisitos essenciais em apresentações consideradas eficientes em seus efeitos de cativar o telespectador: caracterização dos personagens; estabelecimento da atmosfera da história central; indicação do conflito presente na trama principal; além de algumas tramas 
secundárias e seus respectivos personagens. Por tratar-se da adaptação de um romance histórico, o autor possui um controle maior sobre a trajetória das personagens e de suas ações (Pallottini, 1998). Assim, Beija, Antônio, Aninha e o Ouvidor, concentram em suas esferas as determinações relativas aos demais personagens e a intensidade de seus dramas.

$\mathrm{Na}$ forma corrente da linguagem televisiva o diretor Herval Rossano lançou as bases da história a ser contada em flashes, os quais alternam tramas e subtramas, com seus respectivos condutores, apresentando-nos os personagens e situando-os em seus espaços dramático-cênicos. O diretor, em sua exposição assim dimensionada, permite-nos uma visão geral da atmosfera que cercará a trama central, apresentada num ritmo acelerado, já que o conflito motor do drama irrompe quase ao mesmo tempo em que é apenas sugerido. A progressão dramática, em sua função de apresentar elementos que preparem o conflito, não foi descartada, porém, aconteceu de forma a surpreender o telespectador em sua expectativa de poder acompanhar, comodamente, a evolução do drama.

Foi assim que, como nos conta Zevi Ghiveider, diretor da Manchete:

Só no capítulo de estréia, o espectador viu Ana Jacinta de São José nascer, receber o apelido de "Beija" - por ter a vivacidade de um beijaflor -, soube que ela era filha de mãe solteira e acompanhou o crescimento da menina. Ainda no mesmo capítulo, morreram os avós e a mãe de Beija (Maitê Proença), que ficou noiva de Antonio Sampaio (Gracindo Jr.) mas foi raptada pelo ouvidor do rei, Joaquim Inácio Silveira da Mota (representado pelo ex-galã Carlos Alberto, que não aparecia na televisão há dez anos) ${ }^{73}$

Tudo isso, e ainda um farto aparato cênico cuidadosamente construído e apresentado tanto nas cenas gravadas externamente (o arraial caracterizado em seus elementos essenciais, tais como a igreja, a delegacia, a taverna, a praça central, etc.), como nas gravadas nos cenários destinados aos protagonistas, assim como Beija e Antônio Sampaio, (a casa do avô de Beija e a fazenda da família Sampaio), cativaram, já de início, a atenção do público. Não faltaram ao primeiro capítulo, nem espaço, nem ambiente para uma breve passagem pelos jardins palacianos da Corte de D. João VI, no Rio de Janeiro, na qual a família real e um sem número de cortesãos dedicam-se às frivolidades reais, tudo isso como pano de fundo para a apresentação do vilão da história: o Ouvidor Joaquim Inácio Silveira da Mota. Para completar as forças opositoras ao par romântico - Beija e Antônio, visivelmente predestinados um ao outro -, surge Aninha, que, ainda criança, olha com desalento a atenção dispensada por Antônio à Beija na saída da missa.

\footnotetext{
${ }^{73}$ http://www.fortunecity.com/lavender/tomatoes/792/novelas/donabeija.htm
} 
Finalizando, o que certamente provocou índices de audiência inesperados para a telenovela Dona Beija foi o fato de, ainda no primeiro capítulo, acontecer a exibição da primeira das quinze cenas em que Maitê Proença revela a nudez de Beija. Tais cenas foram dosadas pela mão experiente de Herval Rossano, que as utilizou no decorrer da novela com calculadas pitadas de erotismo, determinado pela forma gradativa com que atriz e personagem foram despidas pela câmera e pelos momentos-chave, tanto do ponto de vista estéticodramatúrgico, como da necessidade de manter os níveis de audiência inicialmente conquistados. $^{74}$

A imprensa registrou quando da estréia de Dona Beija:

Na semana da estréia da novela, Maitê Proença apareceu com os seios nus em três cenas. Na primeira, ela se banhou numa cachoeira, a metros da câmera. Depois, Beija se untou com a lama medicinal de Araxá, já mais próxima do espectador, mas de lado. Na terceira cena, a atriz se mostrou bastante, abraçando Gracindo Jr. ${ }^{75}$

Após tais demonstrações, o público esperava cativo o capítulo diário de Dona Beija.

Para Maitê Proença, o sucesso deveu-se, sobretudo, ao tema da novela: "Falamos de História do Brasil num país que não tem memória. Em alguns dias conseguimos $40 \%$ de ibope, numa época em que não havia o zapeamento do controle remoto" (Guanabara, 2006).

Embora pense assim a atriz, a trama amorosa foi o ponto forte da novela. Mais adiante veremos que pouco destaque foi dado ao fato da questão territorial mineira, na qual Beija teria atuado.

Para terminar a observação baseada nas doze cenas selecionadas, percebemos que pequenos indícios nos conduzem ao momento de tensão máxima, à eclosão do conflito, expresso no rapto de Beija e no caráter irreversível das conseqüentes mudanças ocorridas na vida da vítima. Vejamos.

Depois de conhecermos Beija como boa menina, criada nos bons princípios morais, querida por todos, somos conduzidos ao Rio de Janeiro onde somos informados da próxima visita do Ouvidor Joaquim Inácio a São Domingos de Araxá. Em Joaquim já percebemos, em traços sutis, o contorno do vilão, daquele que, por certo, fará mal a nossa heroína. Voltamos ao arraial de São Domingos de Araxá e, ao saber da próxima viagem de Antônio, noivo de Beija que, ao se despedir dele, diz ter medo de perdê-lo, confirmamos nossos temores: Beija

\footnotetext{
${ }^{74}$ Pelo menos nos três primeiros capítulos, a nova investida da Manchete no terreno da fícção histórica rendeu bons dividendos. A rede esperava uma audiência de $10 \%$ dos espectadores e acabou conseguindo cerca de $20 \%$ no Rio de Janeiro e 6\% em São Paulo. No total, portanto, superou suas expectativas.

${ }^{75} \mathrm{http} / / / \mathrm{www}$. fortunecity.com/lavender/tomatoes/792/novelas/donabeija.htm.
} 
estará indefesa quando o Ouvidor passar por Araxá. Quando esperamos por Beija no baile oferecido ao Ouvidor, sentimos mais próximo o momento em que ocorrerá a "tragédia" e, então, ela ocorre: Beija é raptada e seu avô é morto. Estamos irremediavelmente presos aos ditames do destino de Beija. Se não conhecemos sua história, como abandoná-la agora? Como telespectadores, não é o que faremos. Acompanharemos Beija a Paracatu do Príncipe.

Antes, porém, recapitulemos. Do que vimos no trecho correspondente às doze cenas situação, constantes do bloco identificado como Anos de Formação: acompanhamos uma história bem contada, em que as situações e as gradações de tensão se alternaram com equilíbrio; o universo das personagens principais foi apresentado; e, finalmente, o conflito instaurado.

Paracatu do Príncipe.

É nesse cenário que a personagem será definida nas múltiplas ações representadas. Herval Rossano parece, nesse trecho, ter analisado cada situação do roteiro, decidindo-se por mostrar Beija. Delegou à narração apenas as breves incursões definidoras de passagens históricas, imprimindo um padrão rítmico acelerado nas modificações por que passa a personagem ao se transformar em cortesã do Ouvidor. Nesse fazer diretivo em que conduz o encadeamento de cenas de forma a também conduzir as reações e as emoções do telespectador, Rossano vai traduzindo a personagem de Aguiar Filho que, como nos contou Cony, foi criada pelo roteirista "com pinceladas de ódio e amor, bondade e dureza, instinto e educação".

Já não se trata da Beija que saiu das páginas dos romances para as reduzidas páginas da sinopse da telenovela, nem tampouco a que fora passada em revista por ele, diretor, sua equipe, e pela atriz escolhida para representá-la. Trata-se aqui da personagem Beija que de capítulo em capítulo adquiriu os contornos da personagem de televisão, determinados pelos recursos da teledramaturgia.

$\mathrm{Na}$ televisão, "o personagem é aquilo que o dramaturgo criou no papel, mais os cenários que o circundam, as roupas que veste, o penteado criado para ele, as luzes que o iluminam, as cores pelas quais se optou, todos signos a serem lidos e decifrados pelo espectador" (Pallottini, 1998, p. 145).

No caso da personagem Dona Beija, Rossano utilizou para sua composição esses recursos, mais a "força comunicativa do mito de beleza" (Távola, 1984, p. 288) expresso na figura de Maitê Proença, mesmo antes de sua presença na telenovela. À tal atriz coube interpretar Beija, sendo que no decorrer dessa sua experiência pôde, gradativamente, alinhar- 
se com as particularidades do universo interpretado, com a transformação de Beija, com sua desventura e sua superação.

Especialista em novelas de época, Rossano conseguiu que o elenco interpretasse seus papéis como se à época pertencessem, agindo em consonância com a situação escolhida e com a caracterização pedida. É assim que no interior do palácio da Ouvidoria (cenário das próximas seqüências), Beija, o Ouvidor, escravos e visitantes circulam com naturalidade em meio ao século XIX.

Sob o olhar atento de Rossano, em meio aos outros atores e atrizes, Maitê ganha espaço na tela e na trama. Apesar de ater-se às indicações do autor e do diretor, a atriz acrescenta à personalidade da Beija cortesã e, em breve heroína, traços do seu estilo, possíveis marcas da sua personalidade e da sua beleza, a qual para Artur da Távola (1984) "por si só é potente para determinar os pré-requisitos do estrelato" (p. 292). Com Beija, Maitê estabelece uma "comparsaria". Revela-lhe a essência à medida que a representa com a qualidade dramática necessária à mudança de caráter da personagem.

Porém, não fora isso o que a imprensa registrou quando da apresentação dos primeiros capítulos da telenovela Dona Beija em 1986:

O erotismo de Dona Beija será conduzido por Maitê Proença, que faz agora o seu segundo papel no século passado. Como a Marquesa de Santos, a atriz não estava muito convincente. Ela parecia uma boneca trajando vestidos de baile. Como Beija, Maitê está mais solta e verossímil. Seu grande trunfo, porém, continua a beleza, já que sua expressividade está restrita aos lábios: quando Beija está irada, Maitê estica os lábios, quando fica triste, a boca se contrai. ${ }^{76}$

A crítica mordaz, por sua vez, não invalida o que nós acima registramos e que constataremos em algumas seqüências realizadas em Paracatu logo a seguir analisadas. Além disso, em outros espaços dedicados à crítica novelística em 1986, lemos que Maitê Proença, além de deslumbrante, estaria realizando seu melhor trabalho em teledramaturgia. Em que pese as divergências sobre o desempenho da atriz, valemo-nos, mais uma vez, de Távola (1984), que já nos amparou quando da justificativa da beleza de Maitê Proença em função de seu desempenho e que também a coloca "em fase embrionária de criação tanto de uma obra quanto de um reconhecimento artístico" ( p. 292), antes de figurar como Beija.

Podemos, nesse sentido, acompanhar em Anos de Formação, a construção da personagem Beija pela própria atriz Maitê, na medida em que, na televisão, o trabalho de criação do ator depende de sua capacidade em compor uma representação equilibrada entre o

\footnotetext{
${ }^{76}$ http://www.fortunecity.com/lavender/tomatoes/792/novelas/donabeija.htm
} 
personagem criado pelo autor e o personagem que por ele mesmo será criado através da sua interpretação. "Está, portanto, na adequação da interpretação ao que o personagem significa e ao que o ator constrói para ele o segredo do grande desempenho em televisão" (Távola, 1984, p. 27).

Continuando nosso propósito de acompanhar as cenas-situação, consideraremos, nas que cobrem a permanência de Beija em Paracatu, duas seqüências, aqui tidas como unidades narrativas mais amplas, e por nós montadas de forma a ressaltar a linha de ação dramática de um determinado momento, o que faremos amparados pela personagem Beija.

A seqüência 1, a qual denominaremos, A imolação da vítima, agrupa as cenas 13 a 25. Nelas acompanharemos o movimento desencadeado pelo desejo do vilão, o Ouvidor, de possuir Beija. Tolhido pela agressividade com que a vítima o repele, o Ouvidor inicia uma série de tentativas externas, que demandam a cumplicidade de outras pessoas, incluindo o padre Melo Franco, tentativas essas que demarcam a situação dramática inicial: os ataques do Ouvidor à sua vítima; a posição inflexível de Beija; a atuação do padre Melo Franco.

As ações rápidas e eficientes em sua função narrativa, ocorridas em Paracatu, e que podem ser tomadas como preparatórias para o já sabido desfecho, são intercaladas com as incursões da câmera em São Domingos de Araxá. Aí tal foco registra ora em locais públicos, ora na fazenda da família Sampaio, as opiniões sobre Beija - suas virtudes, sua infelicidade ou felicidade junto do Ouvidor - e, através de breves passagens, localiza Antônio em seu caminho de volta, ansioso por rever sua noiva. Nesses momentos, nós telespectadores somos mantidos sob o controle do ritmo acelerado das cenas e das muitas indicações que nos mantêm de prontidão para defender Beija do Ouvidor e consolá-la por suas perdas. Beija, em dados momentos em seu quarto, e em outros na sala, é assediada pelas palavras e atitudes de todos que ali vão a mando do Ouvidor, o que já dá os elementos indicadores do conflito que Beija terá com a sociedade e com Antônio e sua família, além da impossibilidade de voltar a ser o que era, moça digna e casadoura. Entramos e saímos do quarto de Beija e, quando ela pela primeira vez nos acompanha à sala de jantar, lá encontra Moisés e Flaviana, escravos de seu avô que o Ouvidor mandara buscar para agradá-la. Certamente, pensamos, agora ela cederá. Mas, a cena 21 nos surpreende: não é o Ouvidor que acompanha Beja a seu quarto, mas o padre Melo Franco. Será ele o enviado divino para salvá-la das garras do Ouvidor? Todos os indícios foram dados e sabemos que o fim, seja qual for, está próximo, mesmo porque as emoções, dosadas intencionalmente pela narrativa televisiva, confirmam nossas suspeitas e as intenções do autor. E, então, o padre com seu discurso moralizante e sedutor 
conduz Beija para os braços do seu raptor, mas não sem antes tê-la nos seus. ${ }^{77}$ Na cena $^{2} 24$ ficamos sabendo pelo raptor que, indiferente ao crime por ele praticado, reclama ao padre Melo Franco, o seu direito de violar uma virgem. Em rara oportunidade a telenovela denuncia a triste condição da mulher no século XIX. Termina a sequiência e a viagem de Antônio que, na cena seguinte, quando já não poderia mais salvar Beija, retorna a São Domingos de Araxá.

No próximo capítulo, na cena 27, deparamo-nos com uma nova Beija. Essa, ao lado do Ouvidor, assiste à missa domingueira, de modo que não escapa à população de Paracatu os olhares apaixonados trocados entre ela e o padre Melo Franco. A cena é carregada de indicações da mudança fundamental ocorrida na personagem, mudança essa exteriorizada na forma como ostenta o figurino elegante e rico, os adereços que complementam sua aparência cuidadosa e, finalmente, a mudança expressa na postura e na expressão próprias de uma mulher determinada e independente.

$\mathrm{Na}$ seqüência 2, ainda na igreja, percebemos o início de uma nova fase também da narrativa, que cuidará de Beija a cortesã do Ouvidor, personagem título do trecho localizado entre as cenas 26 e 53, o qual, a partir de agora, concentrará nossas atenções.

Nessa rápida aproximação, veremos que o foco narrativo continua centrado na vítima, à maneira dos melodramas, dela nos revelando, porém, não só o sofrimento, mas a determinação com que transformou o seu infortúnio em fonte de poder e de realização pessoal.

Em Paracatu, a ação limita-se praticamente aos cômodos do palácio da Ouvidoria. Em alguns momentos, quando nos sentimos deveras sufocados por tão pesada atmosfera, somos brindados com rápidas passagens externas no campo (quando Beija cavalga e nas imediações da fazenda do padre) e nas entradas do palácio da Ouvidoria e da igreja. Nesse exíguo espaço convivemos com: Beija; o Ouvidor; Severina, Flaviana e Moisés (escravos); Sr. Juca (secretário do Ouvidor) e sua esposa; padre Melo Franco; guardas; e raríssimos circunstantes. Beija é a figura dominante e tornou-se obrigatória a partir desse momento da narrativa, onde à figura do Ouvidor, naturalmente indesejável, foi adicionada, à época da exibição da telenovela Dona Beija, a rejeição da crítica feita ao ator Carlos Alberto:

Já o veterano Carlos Alberto, que representou inúmeros papéis em novelas de época e estava afastado do vídeo desce Bravo! da Globo, passeia por Dona Beija com o mesmo ar impassível de sempre. Carlos Alberto não é um

\footnotetext{
77 Identificamos nessa passagem que não consta dos romances de Vasconcelos nem no de Leonardos, uma menção clara ao que foi comprovado documentalmente, de ser Thereza Thomazia de Jesus, a primeira filha de Beja, nascida em 15 de fevereiro de 1819, em São Domingos de Araxá, filha do padre Francisco José da Silva, conforme Capítulo II desta tese.
} 
ator de talento notável, mas não poderia estar ausente numa novela que recupera o prestígio dos temas históricos. ${ }^{78}$

Não sobrou, ao menos em Paracatu, dada a densidade com que a narrativa televisiva tratou o drama pessoal de Beija, espaço nem físico, nem ficcional para o desenvolvimento de tramas secundárias relevantes. A exemplo do romance de Leonardos, privilegiado nesse trecho da novela, Aguiar Filho não "pôs nem dispôs", limitando-se a reservar a cena para Beija e seus desígnios, preparando paralelamente, em São Domingos de Araxá, as outras histórias, "os ramos", que oportunamente seriam unificados ao "tronco" da árvore utilizada por Pallottini para explicar a estrutura da telenovela.

Assim, nos “entreatos", somos conduzidos a São Domingos de Araxá, invariavelmente à praça central, à taberna de Vespasiano, à fazenda da família Sampaio, cenários em que se desenvolve o drama de Antônio Sampaio, noivo de Beija. São acrescentados, ao fim desse trecho, mais dois cenários, o que corresponde à fazenda da família Felizardo (pais de Aninha, a substituta de Beija na vida de Antônio) e à casa da família Mendonça (pais de João Mendonça, ainda ausente da trama mas, futuro rival de Antônio). O drama de Antônio une-se ao de Beija (história nuclear da novela) e, dessa maneira, enquanto nos preocupávamos com Beija, espiávamos desconfiados o que ocorria em São Domingos de Araxá, desejando que Antônio resgatasse Beija e que não ficasse noivo de Aninha. Nada disso aconteceu e Beija, de presente, virou passado, traduzido em flashback na cena 34. Nela, Antônio que está preso no porão da fazenda do pai, lembra de Beija nua e bela, em seus banhos na fonte da Jumenta.

Beija situa-se com naturalidade em seu espaço de "cativa" e dele podemos dizer que traduz a época da história contada. Por se tratar de um espaço resumido, adensa a essência dramática, ajuntando tensão à narrativa. Quarto, sala, salões, gabinete da Ouvidoria aparecem com detalhes ou não, alternando o drama e o espaço, dirigindo a atenção do telespectador para o essencial, Beija e seu drama. Tal procedimento, que tanto pode ter sido indicado no roteiro de Aguiar Filho (rubricas da cena), como, também, criado pela sensibilidade dramática do diretor Rossano, permitiu momentos significativos no encadeamento do drama, como na cena 29.

Beija traja vestido em zibelina vermelha, rico em suas linhas e na sugestão do recato sedutor pretendido pela cortesã. Entra com andar decidido e pára junto a um arcaz, no que poderia ser o gabinete do Ouvidor ou uma ante-sala do gabinete, interrompendo a passagem do Sr. Juca, o secretário do Ouvidor. Ele, fascinado, ouve perplexo o que ela lhe diz - por saber das atividades ilegais por ele praticadas, uma prerrogativa de seu cargo -: será

\footnotetext{
${ }^{78} \mathrm{http}: / / \mathrm{www}$. fortunecity.com/lavender/tomatoes/792/novelas/donabeija.htm
} 
doravante sua parceira nos lucros por ele, ilicitamente, obtidos. A resposta é inaudível mas sabemos ser afirmativa. Beija traz consigo além do vestido vermelho, um atrevimento explícito, resultante do destino cruel que sobre ela se abatera. Nesse momento não é a cortesã do Ouvidor, nem a moça casta de São Domingos de Araxá, nem a prostituta barata que se insinua para o Sr. Juca. Vestida de vermelho é a Beija que, com a cabeça erguida, está pronta para enfrentar o que sobre ela se disser de desprezível, e mais, seu atrevimento será proporcional à desaprovação social que nessa ocasião já sabe ser a ela dirigida. Além de tudo isso é a Beija que se interpôs entre o cenário e o nosso olhar, conduzindo-o para a dor de uma mulher decaída, socialmente rejeitada sem nos dar espaço para observar detalhes cênicos ou outros de qualquer natureza mesmo que, porventura, fossem descritos pela câmera.

A cena provocada pela passagem fortuita do Sr. Juca pelas dependências da Ouvidoria alterou, por sua vez, a ordem desejada em nossa observação da personagem, colocando em destaque a cena 40, na qual ocorre um segundo encontro entre Beija e o secretário do Ouvidor.

Dessa vez, o encontro entre Beija e o Sr. Juca se dá em campo aberto. Beija já aprendera, a essa altura, a usar sua beleza em proveito próprio. Um sóbrio figurino de montaria realça seus encantos, tornando-a irresistível o suficiente para convencer o Sr. Juca a aceitar o seu audacioso convite: tê-la na cama do Ouvidor mediante vultuosa quantia. Uma sucessão de closes mostra, com intensidade, expressões que revelam os propósitos da personagem, confirmado na cena 45, quando Beija recebe, em seu quarto, um rico comerciante (que antes pagou à Severina, em ouro e jóias, para possuí-la), dispensando-o antes da chegado do Ouvidor.

Se os personagens devem agir para mostrar o seu caráter vimos o quanto basta, Beija tomou novo rumo. Não cabem aqui novas interpretações sejam elas de que natureza forem. As que fizemos, anteriormente, nos parecem suficientes. Cabe apenas ressaltar que, roteirista e diretor reforçaram as características de Beija em ação. A câmera a acompanhou passo a passo. Mostrou-nos em cena intermediária, a de número 35, Beja e Severina em ritual religioso na senzala. Embora fala e ação pareçam distanciar-se, é confirmado o que foi anunciado no convite feito ao Sr. Juca, mudando o curso dos acontecimentos: Beija amaldiçoa todos os homens que a tocarem, dando a cena por encerrada. Porém, fica o que ela disse explicitando o seu conflito interno. Não era o que ela queria, entretanto:

O estupro e o rapto, portanto, separam Beija não apenas de sua família, de seu noivo e de sua cidade, como também das mulheres virgens e casadas. $\mathrm{O}$ estupro de Beija transforma-a (...) Sua transformação possui ainda outra 
característica: não foi desejada por ela. O Ouvidor conquistou seu corpo, mas não dominou sua vontade. (...) Não tendo família a representar e tendo perdido sua honra, ela se define então apenas pela sexualidade. (Abreu Filho 1983, p. 87)

O Ouvidor não dominou a vontade de Beija, vontade essa responsável (em cena não identificada em nossos recortes, talvez, por ter sido meramente narrativa) pelo retorno das terras do Triângulo Mineiro à Província de Minas Gerais. ${ }^{79}$

Para a televisão tal feito não se fez importante. Em sua narrativa preferiu manter o tom erótico e feminista que pontuou a trama amorosa de Dona Beija, a qual privilegiava feitos valorativos de outras qualidades tais quais a da mulher determinada e livre que dirigia sua sexualidade e sua própria vida. Na telenovela, Beija, ao passar de vítima a mulher sedutora e independente, "é poderosa, rica, detém a iniciativa nas relações com os homens que, diante dela, se tornam tímidos e recatados como as mulheres" (Abreu Filho, 1983, p. 88).

Embora a personagem Beija da televisão tenha nascido da imaginação de Vasconcelos e de Leonardos, ela se liberta, ao deixar Paracatu, de qualquer traço inicialmente devido à aproximação com os romances, levando consigo a sua autonomia construída, agora, pela “(...) extrema eficácia da câmera, no seu papel de olho que acompanha o personagem e nos mostra, passo por passo, quem ele é (...)" (Pallottini, 1989, p. 75).

Dessa forma, vemos Beija e Severina na cena 31. Um grande baile está acontecendo nos salões da Ouvidoria. Beija, ainda em seus aposentos, veste-se auxiliada por Severina. Não há motivo para palavras nem colocações desnecessárias. Nesta cena a câmera é o narrador principal. Já comentou cenários e figurinos em minúcias e já nos segredou que Beija preparou uma aparição espetacular: vestiu-se de forma totalmente desusada. Seu figurino (talvez fantasia), embora rico em textura e cores, não se integra ao ambiente, à situação e nem às pessoas, as quais vestidas no padrão desejável para a época e a ocasião, esperavam pela chegada da cortesã do Ouvidor. Ela terminara de se vestir. O vestido trazia corpete em cetim em nada arrojado. De corte simples, porém cuidado, não revelava nada a mais do que a forma arredondada dos seios. A câmera iniciou o exame do figurino pela parte superior e frustou nossas expectativas, a essa altura grandes, em função da espera prolongada e do fato de ser o primeiro baile de Beija em Paracatu, ocasião na qual, supostamente, seria aceita entre as pessoas de "bem" da sociedade local. Os cabelos penteados e enfeitados com tiara de ouro, o rosto invariavelmente belo. A câmera, cada vez mais minuciosa, refaz o percurso e desce mostrando a saia que complementa o figurino. Seu corte, sua transparência, suas muitas cores,

\footnotetext{
${ }^{79}$ Conforme Capítulo I desta tese.
} 
seu corte irregular em pontas que caem em alturas variadas sobre pernas bem torneadas é o que esperávamos ou, se não era, foi o que fez de Beija uma figura inesquecível. E, assim desvendada, ainda a sós com Severina, revela: "não sou mais a mesma mulher”. Sem nos deter nas tomadas e nos planos que compuseram a cena, o que não caberia em nossos propósitos, podemos, entretanto, acentuar que o trabalho executado pela câmera nos fez cúmplices dessa confissão. Foi a detalhada descrição do figurino de Beija que determinou a dimensão da mudança da personagem, tornando-a o foco da cena e da ampliação da tensão.

Ao final, ficam claros para o telespectador a mudança do caráter de Beija, assim como os indícios dos problemas e conflitos que pontuarão o desenvolvimento da trama da novela. Por certo, lá estarão no segundo bloco por nós denominado Anos de Ouro, montado a partir das cenas-situação abaixo colocadas.

Os telespectadores que ao início da novela viram Dona Beija com certa parcimônia, em seus Anos de Formação, foram envolvidos pelos encantos de Beija e não mais a abandonaram, mesmo porque o problema, a promessa, e a expectativa criados em capítulos diários fizeram com que o telespectador partilhasse da solidão e do desamparo da personagem, torcessem para que Antônio conseguisse resgatá-la e se preocupassem quando o Ouvidor anunciou sua partida para o Rio de Janeiro e Beija a sua volta para São Domingos de Araxá. Assim, não há escolha para esse telespectador a não ser seguir Beija e Maitê Proença em seu regresso para São Domingos de Araxá.

\section{ANOS DE OURO (cenas-situação: 54 a 178) SÃO DOMINGOS DE ARAXÁ}

\section{CENA 54 - ARREDORES DE SÃO DOMINGOS DE ARAXÁ - EXT. - DIA}

Vista geral do arraial.

Beija chega. Rica e bela traz enorme fortuna

CENA 55 - SÃO DOMINGOS DE ARAXÁ - DELEGACIA - INT. - DIA

Moisés (escravo de Beija) pede ao guarda que entregue as chaves da casa do avô de Beija, ali guardadas desde o triste acontecimento que marcou o seu rapto.

CENA 56 - ARREDORES DE SÃO DOMINGOS DE ARAXÁ - EXT. - DIA

Moisés retorna e entrega as chaves a Beija que diz: "a Beija de Paracatu está morta." 
Pais e irmã de Antônio comentam a volta de Beija. Estão preocupados com Antônio e seu próximo casamento com Aninha.

CENA 58 - FAZENDA DA FAMÍLIA FELIZARDO - INT. - DIA

Pais contam a Aninha sobre o retorno de Beija.

CENA 59 -CENTRO - EXT. - DIA

Beija entra na igreja acompanhada pelo padre Aranha. Antônio a vê, de longe, e sai a galope.

CENA 60 - CASA DO JUIZ - INT. - DIA

Na sala o juiz e sua esposa falam sobre a grande novidade: a volta de Beija.

CENA 61 - IGREJA - INT. - DIA

Na sacristia, Beija diz ao padre Aranha que ama Antônio.

CENA 62 - CASA DE BEIJA - INT. - NOITE

Antônio vai vê-la. Ainda se amam. Beija pede que decida: ela ou Aninha.

CENA 63 - FAZENDA DA FAMÍLIA SAMPAIO - INT. - DIA

Antônio avisa que decidirá entre Beija e Aninha. A família o pressiona. Ele não deve se casar com Beija.

CENA 64 - CASA DE BEIJA - INT. - NOITE

Antônio diz a Beija que se casará com Aninha. Beija chora.

CENA 65 - CENTRO - EXT. - DIA

Cortejo do casamento de Antônio e Aninha.

CENA 66 - CASA DE BEIJA - EXT. - DIA

Beija chora.

CENA 67 - BORDEL - INT. - NOITE

Candinha da Serra fala de Beija: sua beleza, sua fortuna e o sobrado em construção no Largo da Matriz.

CENA 68 - CASA DO LARGO DA MATRIZ - SALA - INT. - NOITE

Beija discute com seus velhos amigos, acerca da obra da chácara do Jatobá.

CENA 69 - CHÁCARA DO JATOBÁ - SALÃO - INT. - DIA

Festa de inauguração. Beija reina entre os homens.

CENA 70 - FAZENDA DA FAMÍLIA SAMPAIO - JARDIM - EXT. - NOITE

Aninha conta a Antônio que está grávida.

CENA 71 - CHÁCARA DO JATOBÁ - SALÃO - INT. - DIA

Beija diverte-se com seus convidados.

CENA 72 - FAZENDA DA FAMÍLIA SAMPAIO - QUARTO - INT. - NOITE

Antônio e Aninha se amam. 
CENA 73 - CHÁCARA DO JATOBÁ - SALÃO - INT. - DIA

Beija escolhe entre os convidados aquele que passará a noite com ela.

CENA 74 - FONTE DA JUMENTA - EXT. - DIA

Beija, nua, toma banho.

CENA 75 - FAZENDA DA FAMÍLIA SAMPAIO - QUARTO - INT. - NOITE

Antônio, ao lado de Aninha, não consegue esquecer Beija.

CENA 76 - CHÁCARA DO JATOBÁ - SALÃO - INTE. - DIA

Beija dança para convidados seletos e pagantes.

CENA 77 - FAZENDA DOS SAMPAIO - JARDIM - EXT. - NOITE

Aninha está perdida diante da situação. Antônio não quer sua companhia.

CENA 78 - CHÁCARA DO JATOBÁ - SALÃO - INT. - DIA

Beija dá ordens aos seus escravos: receber bem e zelar pela sua segurança.

Severina cuida das finanças.

CENA 79 - ARRAIAL - TABERNA DO VESPASIANO - INT. - NOITE

Antônio, triste e cabisbaixo, bebe. Ouve o que dizem sobre o Jatobá e decide procurar Beija.

CENA 80 - CASA DO LARGO DA MATRIZ - JARDIM - EXT. - NOITE

Antônio chega e discute com Beija que o manda procurá-la no Jatobá, como qualquer um de seus clientes e, como eles, faça devidamente o pagamento pelos seus favores. Ele sai enfurecido.

CENA 81 - FAZENDA DA FAMÍLIA SAMPAIO - CAMPO - EXT. - DIA

Antônio e Vado conversam sobre Beija. Ele não pode viver sem ela.

CENA 82 - CHÁCARA DO JATOBÁ - SALÃO - INT. - DIA

Antônio aguarda, como os outros, a possibilidade de ser escolhido por Beija. Ela decide-se por um forasteiro retirando-se, com ele, para os seus aposentos.

CENA 83 - ARRAIAL - TABERNA DO VESPASIANO - INT. - NOITE

Fortunato, Galdêncio e Belegarde, figuras locais, falam maravilhas sobre Beija.

CENA 84 - CHÁCARA DO JATOBÁ - SALÃO - INT. - DIA

Antônio retorna e aguarda. Após breve diálogo Beija capitula e Antônio fica.

CENA 85 - FAZENDA DA FAMÍLIA SAMPAIO - SALA - INT. - DIA

Aninha (grávida) e a mãe de Antônio comentam sua ausência.

CENA 86 - CHÁCARA DO JATOBÁ - QUARTO DE BEIJA - INT. - DIA

Beija e Antônio tomam café na cama. Felizes falam de amor.

CENA 87 - BORDEL - INT. - NOITE

Cel. Felizardo, pai de Aninha, fala de Beija e Antônio. 
CENA 88 - CHÁCARA DO JATOBÁ - QUARTO DE BEIJA - INT. - DIA

Beija e Antônio na cama. Ela, apaixonada, diz que ele poderá vê-la no sobrado do Largo da Matriz.

CENA 89 - FAZENDA DA FAMÍLIA SAMPAIO - QUARTO - INT. - DIA

Aninha dá à luz mais um filho, sem a presença de Antônio.

CENA 90 - CHÁCARA DO JATOBÁ - QUARTO DE BEIJA - INT. - DIA

Beija e Antônio na cama.

CENA 91 - FAZENDA DA FAMÍLIA SAMPAIO - QUARTO - INT. - DIA

Antônio volta e pede perdão a Aninha.

CENA 92 - CASA DO LARGO DA MATRIZ - SALA - INT. - DIA

Beija comunica sua gravidez para Antônio, que diz não saber se é o pai.

CENA 93 - FAZENDA DA FAMÍLIA SAMPAIO - SALA - INT. - DIA

Aninha cuida dos filhos e sua sogra conta a ela a gravidez de Beija. Todos sabem que é filho de Antônio. A irmã de Antônio se revolta.

CENA 94 - CASA DO LARGO DA MATRIZ - SALA - INT. - DIA

Antônio quer assumir a paternidade do filho que Beija espera. Ela não aceita.

CENA 95 - FAZENDA DA FAMÍLIA SAMPAIO - SALA - INT. - DIA

Aninha recebe seus pais que comentam a gravidez de Beija. A mãe e a irmã de Antônio estão presentes. Essa última se despede e sobe para o quarto. Com a arma de Antônio tenta matar-se. Ao ver o irmão ao seu lado o faz jurar que deixará Beija.

CENA 96 - IGREJA - INT. - DIA

Beija (grávida) e Aninha se encontram. Ofendem-se. Aninha está certa de que Antônio deixará Beija e Beija de que ele não a abandonará.

CENA 97 - CASA DO LARGO DA MATRIZ - SALA - INT. - NOITE

Antônio veio para se despedir e assim o fazem, acreditando Beija e ele ser para sempre.

CENA 98 - CASA DA FAMÍLIA MENDONÇA - INT. - DIA

Avelino (maestro) e a mãe de João falam de amor.

CENA 99 - CASA DO LARGO DA MATRIZ - QUARTO - INT. - DIA

Beija dá à luz uma menina: Thereza Thomásia de São José.

CENA 100 - CASA DO LARGO DA MATRIZ - SALA - INT. - DIA

Severina mostra Thereza para os amigos de Beija.

CENA 101 - CASA DA FAMÍLIA MENDONÇA - SALA - INT. - DIA 
A mãe de João comenta com Avelino a formatura do filho em Direito e sua próxima chegada.

CENA 102 - CHÁCARA DO JATOBÁ - SALÃO - INT. - DIA

Beija reinicia suas atividades. Fortunato pede que realize seu sonho: ver Beija tal qual Lady Godiva. Beija consente.

CENA 103 - ARRAIAL - CENTRO - EXT. - NOITE

Beija surge nua sobre seu cavalo branco, puxada por Severina. Seus admiradores assistem com respeito. Entre eles, surge João Mendonça recém chegado da Corte.

CENA 104 - IGREJA - INT. - DIA

Avelino procura Padre Aranha. Confessa seu amor pela mãe de seu amigo João Mendonça.

CENA 105 - CASA DO LARGO DA MATRIZ - SALA - INT. - DIA

João Mendonça, encantado com a aparição de Beija na noite anterior, foi vê-la. Juntos, lembram da infância e das aulas de catecismo com o Padre Aranha.

CENA 106 - FAZENDA DA FAMÍLIA SAMPAIO - QUARTO - INT. - NOITE

Aninha diz que precisa de Antônio. Ele pensa em Beija.

CENA 107 - FONTE DA JUMENTA - EXT. - DIA

João acompanha Beija em seu ritual de beleza e, juntos, se banham, nus, na fonte.

CENA 108 - FAZENDA DA FAMÍLIA SAMPAIO - JARDIM - EXT. - DIA

Antônio e Vado conversam. Antônio tem cíúmes de João Mendonça.

CENA 109 - CHÁCARA DO JATOBÁ - QUARTO - INT. - DIA

Beija e João Mendonça na cama.

CENA 110 - FAZENDA DA FAMÍLIA SAMPAIO - SALA - INT. - DIA

Aninha conta a Antônio que Beija é amante de João Mendonça.

CENA 111 - CASA DO LARGO DA MATRIZ - SALA - INT. - DIA

A mãe de João Mendonça visita Beija. Intercede pelo filho. Beija nada promete.

CENA 112 - FONTE DA JUMENTA - EXT. - DIA

Beija e João Mendonça são interceptados por Antônio e seus homens. Antônio os ameaça. Beija toma a frente e passa por todos sem medo.

CENA 113 - CASA DA FAMÍLIA MENDONÇA - SALA - INT. - DIA

Avelino vai embora para o Rio de Janeiro e se despede da mãe de João.

CENA 114 - CHÁCARA DO JATOBÁ - SALA - INT. - DIA

Beija avisa Severina que vai parar, por um tempo, as atividades da chácara. 


\section{CENA 115 - FAZENDA DA FAMÍLIA SAMPAIO - QUARTO - INT. - NOITE}

Antônio pede a Aninha para criar Thereza, sua filha com Beija. Aninha recusa.

CENA 116 - ARRAIAL - LAGO - EXT. - DIA

Avelino e Josefa (mãe de João) se encontram.

CENA 117 - ESCRITÓRIO - INT. - DIA

João e o pai trabalham.

CENA 118 - ARRAIAL - LAGO - EXT. - DIA

Avelino e Josefa se despedem.

CENA 119 - CASA DO LARGO DA MATRIZ - SALA - INT. - DIA

Antônio invade a casa de Beija para ver Thereza. Beija consente.

CENA 120 - CASA DO LARGO DA MATRIZ - SALA - INT. - DIA

Fortunato confirma: Beija está grávida de João.

CENA 121 - ESCRITÓRIO - INT. - DIA

Severina pede que João a acompanhe. Dona Beija precisa vê-lo.

CENA 122 - CASA DO LARGO DA MATRIZ - INT. - DIA

Beija dá a notícia a João, que a recebe com alegria.

CENA 123 - FAZENDA DA FAMÍLIA SAMPAIO - SALA - INT. - DIA

Aninha conta para Antônio que Beija está grávida de João.

CENA 124 - CENTRO - EXT. - DIA

Beija, João e padre Aranha passeiam. Param ao verem Antônio chicoteando um escravo. Beija, ao que parece, sente prazer com a cena.

CENA 125 - CASA DO LARGO DA MATRIZ - QUARTO - INT. - DIA

Nasce Joana de Deus de São José, filha de Beija e João.

CENA 126 - BORDEL - INT. - NOITE

Freqüentadores falam de política, provocando discussões entre liberais e conservadores. João Mendonça entra e Candinha comenta: Beija voltou para Antônio.

CENA 127 - CENTRO - EXT. - DIA

Guarda anuncia alistamento para a guarda nacional. (1831)

CENA 128 - CENTRO - EXT. - DIA

Antônio passa a galope. (1835)

CENA 129 - CASA DO LARGO DA MATRIZ - SALA - INT. - DIA

Thereza não quer se casar com Botelho. Ela e a mãe discutem. Antônio aparece e exige que Beija não convide os Mendonça para o casamento da filha. Beija e Antônio discutem: ela é a dona da casa e, portanto, quem decide. 
CENA 130 - FAZENDA DA FAMÍLIA SAMPAIO - SALA - INT. - DIA

Aninha, a mãe de Antonio e os filhos discutem sobre o comparecimento de Antônio ao casamento de Thereza. Ele, irredutível, diz que acompanhará Beija na cerimônia.

CENA 131 - CENTRO - EXT. - DIA

Cortejo do casamento de Thereza. (Antônio, Beija, autoridades locais e convidados)

CENA 132 - CASA DO LARGO DA MATRIZ - SALA - INT. - NOITE

Festa do casamento de Thereza. Antônio bebe e cria problemas para Beija ao desacatar os Mendonças. Ao mesmo tempo, discussões políticas ocupam grupos de convidados, salientando-se as questões sobre regência e república.

CENA 133 - CASA DA FAMÍLIA MENDONÇA - SALA - INT. - NOITE

João é informado pelos pais sobre o comportamento de Antônio.

CENA 134 - CASA DO LARGO DA MATRIZ - SALA - INT. - NOITE

Fim da festa. Beija rompe com Antônio. Não aceita que ele mande em sua casa e em sua vida.

CENA 135 - DELEGACIA - INT. - DIA

Guardas foram informados da possível passagem de Quarentinha (perigoso assassino) por São Domingos de Araxá.

CENA 136 - FONTE DA JUMENTA - EXT. - DIA

Prostituta é assassinada pelo bandido.

CENA 137 - CASA DA FAMÍLIA MENDONÇA - SALA - INT. - DIA

Despedida do pai de João que, junto com outras autoridades, sairá a procura do assassino.

CENA 138 - CASA DO LARGO DA MATRIZ - INT. - DIA

Belegarde relata a Beija o ocorrido na fonte e pede que tome cuidado.

CENA 139 - ARRAIAL - CAMPO - EXT. - DIA

Pai de João Mendonça é morto pelo bandido.

CENA 140 - FAZENDA DA FAMÍLIA SAMPAIO - CAMPO - EXT. - DIA

Antônio e Vado conversam. Antônio não sabe viver sem Beija.

CENA 141 - CASA DO LARGO DA MATRIZ - QUARTO - INT. - DIA

Beija consola João pela morte do pai. Antonio invade o quarto e Beija confirma: não o quer mais. 
CENA 142 - CHÁCARA DO JATOBÁ - JARDIM - EXT. - NOITE

Antônio chega para um encontro marcado com Beija, que não compareceu e mandou Moisés (escravo) deixar o cão solto. Antônio é atacado e ferido gravemente.

CENA 143 - CASA DO FORTUNATO - SALA - INT. - NOITE

Fortunato socorre Antônio.

CENA 144 - CASA DO LARGO DA MATRIZ - SALA - INT. - DIA

João Mendonça comenta com Beija sobre o acidente ocorrido com Antônio. Beija não se manifesta. João que percebeu ter sido ela a responsável diz ter medo dela e de suas atitudes maldosas.

CENA 145 - FAZENDA DA FAMÍLIA SAMPAIO - QUARTO - INT. - NOITE

Aninha e Antônio conversam sobre o acidente. Aninha diz que Beija é capaz de tudo para prejudicá-lo.

CENA 146 - DELEGACIA - INT. - DIA

Botelho e o delegado conversam sobre política.

CENA 147 - ARRAIAL - CAMPO - EXT. - DIA

Antônio contrata dois jagunços para surrar Beija.

CENA 148 - FONTE DA JUMENTA - TRILHA - EXT. - DIA

Beija e Severina são surpreendidas pelos jagunços que atacam Beija. Severina grita e tenta defender sua sinhá. Enquanto isso Beija é brutalmente surrada. Nas proximidades um pesquisador estrangeiro ouve os gritos e corre para prestar socorro. Encontra Severina desolada e Beija quase morta.

CENA 149 - FAZENDA DA FAMÍLIA SAMPAIO - SALA - INT. - DIA

Antônio diz à mãe que estão vingados.

CENA 150 - CASA DO LARGO DA MATRIZ - QUARTO - INT. - DIA

Beija muito ferida é atendida por Fortunato, Severina, as duas filhas e João.

CENA 151 - FAZENDA DA FAMÍLIA SAMPAIO - SALA - INT. - DIA

Aninha pergunta a Antônio se foi ele quem mandou surrar Beija. Ele nada responde.

CENA 152 - CASA DO LARGO DA MATRIZ - SALA - INT. - DIA

Beija recebe a confirmação: foi Antônio o mandante do crime.

CENA 153 - IGREJA - INT. - DIA

Na sacristia padre Aranha ouve a confissão de Josefa: ela teve um caso com Avelino. João ouve e fica transtornado. 
CENA 154 - CASA DO LARGO DA MATRIZ - SALA - INT. - DIA

Beija recebe o coronel e pede a ele que mande matar os negros que a surraram.

CENA 155 - ARRAIAL - CAMPO - EXT. - DIA

Os agressores de Beija são mortos pelos homens do coronel Botelho.

CENA 156 - CASA DO LARGO DA MATRIZ - SALA - INT. - DIA

Beija recebe a confirmação de que sua vontade foi cumprida.

CENA 157 - PARACATU DO PRÍNCIPE - GARIMPO - EXT. - DIA

Escravo negro esconde diamante que encontrou e foge. Seu sonho: dar o diamante à Beija para tê-la em seus braços.

CENA 158 - ARRAIAL - HOSPEDARIA - INT. - DIA

Avelino chegou e está muito doente.

CENA 159 - CASA DO LARGO DA MATRIZ - SALA - INT. - DIA

Fortunato pede a Beija para receber Avelino e ela concorda.

CENA 160 - CASA DA FAMÍLIA MENDONÇA - SALA - INT. - DIA

João fica sabendo que Beija acolheu Avelino.

CENA 161 - CASA DO LARGO DA MATRIZ - SALA - INT. - DIA

João entra e ordena que Beja mande Avelino embora. Ela, indignada, diz que não o fará. Brigam e se separam para sempre.

CENA 162 - ARRAIAL - ARREDORES - EXT. - DIA

Escravo de Paracatu do Príncipe chega a São Domingos de Araxá.

CENA 163 - CENTRO - EXT. - DIA

Cortejo do casamento de Joana, filha de Beija e João Mendonça.

CENA 164 - CHÁCARA DO JATOBÁ - JARDIM - EXT. - DIA

Beija é procurada pelo escravo de Paracatu do Príncipe (Ramos).

CENA 165 - FAZENDA DA FAMÍLIA SAMPAIO - QUARTO - INT. - NOITE

Aninha e Antônio conversam. Ela tem medo de que algo aconteça a ele. Tudo está muito bem e, para ela, a felicidade tem pernas curtas.

CENA 166 - CASA DO LARGO DA MATRIZ - JARDIM - EXT. - NOITE

Beija conversa com Ramos. Contrata-o para matar Antônio.

CENA 167 - CENTRO - EXT. - NOITE

Severina mostra Antonio para Ramos.

CENA 168 - CASA DO LARGO DA MATRIZ - QUARTO - INT. - NOITE

Ramos espera por Beija. Ela entra e se entrega a ele, como parte do acordo firmado para que o escravo mate Antonio. 
CENA 169 - TABERNA - INT. - NOITE

Antônio joga na taberna.

CENA 170 - CASA DO LARGO DA MATRIZ - QUARTO -INT. - NOITE

Beija se arruma e entrega para Ramos o restante do pagamento: pedras preciosas que ele guarda em sua bota.

CENA 172 - FAZENDA DA FAMÍLIA SAMPAIO - JARDIM - EXT. - NOITE

Ramos é picado por uma cobra enquanto aguardava sua vítima. Antônio o vê ferido e o socorre.

CENA 173 - CASA DO LARGO DA MATRIZ - SALA - INT. - DIA

Beija, arrependida, conta para João sobre Ramos e seus propósitos. Pede que a ajude. Ela, ainda, ama Antônio.

CENA 174 - FONTE DA JUMENTA - EXT. - DIA

Candinha da Serra e suas meninas tomam banho.

CENA 175 - CHÁCARA DO JATOBÁ - SALA - INT. - DIA

Beija, acompanhada por seus escravos, desmonta a casa.

CENA 176 - FONTE DA JUMENTA - EXT. - DIA

Antônio conversa com Ramos nas proximidades da fonte. Ramos aguarda o momento oportuno e atira em Antônio. Foge. Antônio é socorrido por Candinha e suas meninas. Umas ficam e outras vão avisar Beija.

\section{CENA 177 - CHÁCARA DO JATOBÁ - JARDIM - EXT. - DIA}

Meninas chegam gritando. Beija desesperada segue-as, acompanhada por seus escravos. Ao ver Antônio, abraça-o, sem culpa.

CENA 178 - FAZENDA DA FAMÍLIA BOTELHO - QUARTO - INT. - DIA

Antônio agoniza entre as duas mulheres: Aninha e Beija. Mãe, filhos, mulheres, todos choram. Antônio morre e sua mãe manda Beija se retirar.

Estabelecer um novo ponto de partida para a abordagem do bloco de cenas-situação que compõem Anos de Ouro, não foi tarefa simples. A densidade narrativa e o natural aumento de complexidade impresso à trama, traço peculiar em segundas partes de qualquer narrativa, seja ela teatral ou televisiva, nos aconselharam a não perdermos de vista nosso condutor, a personagem Dona Beija. Se, até aqui, ela nos deu a motivação e o rumo para a localização dos episódios significativos que contemplaram nossos propósitos - vê-la e interpretá-la na televisão -, não devemos correr o risco desnecessário advindo de mudanças de método ou de estratégia na condução do nosso olhar. Portanto, selecionamos, em meio a 
cenas que compõem o quadro geral da narrativa de Anos de Ouro, acima colocadas, os momentos que pensamos ser mais expressivos para representar o drama da vida de Beija, tal qual foi traduzido para a televisão.

Podemos pensar o roteiro televisual de Anos de Ouro na divisão clássica de uma obra dramatúrgica, ou seja, em três atos: o primeiro de antecipação e exposição do problema; o segundo de aprofundamento das crises e conflitos; e o terceiro o da resolução.

No primeiro ato, veremos que as situações dramáticas criadas a partir do retorno de Beija para São Domingos de Araxá desenvolveram-se a partir de seu poder de sedução e de seu poder político. Ambos derivam da influência recebida pela personagem na convivência com o Ouvidor e com os meios econômicos habilmente conquistados como forma de compensar a sua perda existencial, tida pela sociedade local como insuperável. Sob essa perspectiva, Beija deveria cair na vala comum das mulheres decaídas o que, no entanto, não se deu.

No segundo ato, assistiremos ao aprofundamento dos problemas colocados e criados por Beija, originados na forma adversa como se impôs ao contexto sociocultural local, ao buscar sua antiga posição, ou mesmo na impossibilidade de recuperá-la, buscando uma posição "digna" à sua condição de cortesã bem sucedida. Instauram, nesse movimento, os conflitos e as conseqüentes tentativas de equilíbrio que os acompanham. Finalmente, no terceiro e último ato, se dá a resolução.

Portanto, vamos ao primeiro ato. Dele, e dos demais, já conhecemos todos os fatos. Esses foram descritos em situações diversas, como as guardadas na memória familiar, as que foram avalizadas pelos métodos históricos e as que foram criadas pelas traduções culturais, também, por nós abordadas. Diante disso, resta-nos salientar passagens relevantes para a construção e a interpretação da personagem Dona Beija na teledramaturgia.

Em princípio, vamos nos deter em três momentos, o do retorno de Beija; o da consolidação de sua imagem; e o da sua conquista amorosa.

\section{$1^{\circ}$ ATO}

\section{O RETORNO DE BEIJA - (cenas - situação 54 a 67)}

O mesmo plano geral que anunciou, anos antes, a chegada da família de Beija a São Domingos de Araxá, anuncia agora a chegada da nova personagem Dona Beija, rica e bela e, ao que parece, bem intencionada quando anuncia: "a Beija de Paracatu está morta". Uma 
informação indicativa de paz e vida serena ao lado do homem amado e de uma possível prole saudável e igualmente feliz. Mas, sem demora, a câmera invade a fazenda da família Sampaio, a fazenda da família Felizardo, a casa do juiz Costa Pinto, exibindo a preocupação de todos com a presença de Beija, que apesar de vítima do destino, não poderá ser acolhida como antes entre as pessoas de bem, resumidas nos poucos personagens que compõem os núcleos secundários anteriormente apresentados. A eles se junta o padre Aranha, eterno defensor de Dona Beija, que conduz em seu espaço, a igreja, as cenas reveladoras do bem e do mal. É assim que Beija ao chegar, procura-o, em cena montada para mostrá-la, de modo que muitos a viram ao entrar, com ele, na sacristia, incluindo Antônio Sampaio. No momento em que Beija diz ao padre que ainda ama Antônio e o vemos passar, a galope, em seu cavalo, nosso interesse é deslocado para o próximo encontro que sabemos irá acontecer. E, acontece. Antônio procura Beija em sua casa e promete decidir entre ela e Aninha sua noiva. A narrativa caminha a passos lentos de modo a manter nosso interesse.

Acompanhamos, então, Antônio em sua tentativa de convencer sua família a aceitar Beija, e Beija, em sua casa, perdida em seus devaneios inúteis. Antônio, no dia seguinte, volta à casa de Beija. Sua decisão foi tomada e nada há a fazer: Aninha será sua mulher. Beija, desesperada, chora na intensidade pretendida pelo diretor, que reserva para a cena seguinte o ponto alto da situação dramática apresentada na chegada de Beija a São Domingos de Araxá, quando ainda se podia esperar um final feliz para a vítima de rapto e estupro, ele agora é inteiramente descartado: Beija, de sua casa, vê passar o cortejo do casamento de Antônio e Aninha. Todas as emoções são mobilizadas pela narrativa, ficando explícita na cena as intenções do autor em nos conduzir para o deslocamento do papel de Beija, anunciado pela transformação radical das expectativas de início criadas e não concretizadas. A informação vem na voz de Candinha da Serra, dona do bordel local que, em seu posto de permanente observadora, acompanha o desenvolvimento de cada situação dramática protagonizada por Beija. Segundo Candinha, Beija rica e bela empenha-se, após o casamento de Antônio, na construção de um sobrado no Largo da Matriz.

Do visto e registrado nesse primeiro momento, podemos ressaltar a variação na ação e na distribuição do material dramático, dosado, ao que parece, conforme as alterações do interesse do telespectador. Interesse tal que deverá ser mantido mesmo tratando-se de um trecho de transição, cujo objetivo é preparar, anunciar conflitos futuros. Por não representar uma fase "fluente" em relação às curvas dramáticas que se apresentaram anteriormente mais intensas - por ocasião do rapto e das mudanças ocorridas em Paracatu do Príncipe -, Beija deixou o centro da cena. Seu afastamento temporário permitiu que outras ações, com 
diferentes unidades espaciais e temporais adequadas a outros conflitos que não os seus, movimentassem a história central.

Afinal, Beija, desde a estréia da telenovela, havia monopolizado os interesses do público e da Rede Manchete, o que fez de Maitê Proença a responsável pelo sucesso obtido já nos primeiros capítulos. Coube ao diretor, portanto, corrigir um possível desequilíbrio narrativo mostrando mudanças efetivas nas tramas secundárias, mesmo que tais mudanças dissessem respeito ao retorno de Dona Beija. Ao privilegiar as famílias Sampaio, Felizardo, e também a do juiz Costa Pinto, assim como ao fornecer os traços característicos da personalidade do padre Aranha, autor e diretor tiveram a intenção de familiarizar-nos com o novo contexto da história de Beija, a qual passou a ser também a de São Domingos de Araxá. Mesmo sem a força dos personagens dos romances de Vasconcelos e Leonardos que lhes serviram de protótipo, o Cel. Sampaio (Abrahão Farc), Dona Ceci (Maria Fernanda), Maria (Mayara Magri), Cel. Elias Felizardo (Sérgio Mamberti), Genoveva (Arlete Salles), Costa Pinto (Lafayette Galvão), Dna. Augusta (Marilu Bueno), Carminha (Virgínia Campos), e o padre Aranha (Sérgio Brito) foram montados de acordo com as funções a eles destinadas no enredo da telenovela, distribuídas nos muitos ramos da árvore de Pallottini (1998), já que deve o autor "ter a habilidade de distribuir o peso dos ramos de sua criação para impedir que venha tudo abaixo" (p. 60).

\section{CONSOLIDAÇÃO DA IMAGEM DE BEIJA - (Cenas 68 a 87)}

Antecipando-se a possíveis conjecturas que poderíamos tecer sobre as consequiências e a extensão do abandono e rejeição de Beija pela sociedade, formalizado pelo casamento de Antônio com Aninha, a câmera nos conduz a dois novos ambientes. Eles revelam em suas atmosferas o drama da vida de Beija: o sobrado do Largo da Matriz e a chácara do Jatobá. Por sabermos da importância dos cenários na composição da narrativa televisiva, faremos deles, no trecho a seguir, o centro de nossas observações.

Além dos que definem o espaço reservado à protagonista - sua casa no arraial, a chácara do Jatobá e a fonte da Jumenta -, acompanhamos agora, de forma detalhada, os usos e costumes da família Sampaio em sua casa da fazenda, assim como os seus dramas familiares, que se avolumam e ultrapassam a intimidade do quarto de Antônio e Aninha, alojando-se nas salas, varandas e jardins. Na forma previsível para nós, espectadores, os capítulos alternam cenas nos cenários de um e de outro protagonista e, quando tal jogo se torna cansativo, leva- 
nos para os espaços públicos. Dessa forma nos familiarizamos com a desbotada taberna do arraial, ambientada em arrumação pouco convidativa, e rapidamente passamos pelo bordel, lá permanecendo o suficiente para ouvir o que a nós se destina, usado como recurso dramático narrativo, ou seja, o comentário feito pelo pai de Aninha, que, como um arauto, confirma aos presentes a paixão vivida por Beija e Antônio.

Da personagem que sabíamos ser senhora de sua vida e seus atos, sabemos agora, ao vê-la atuando no sobrado ou na chácara, ter ela determinação suficiente para conduzir sua própria vida, para o bem ou para o mal, assim colocados conforme os padrões vigentes em seu tempo e por ela obedecidos nas rotinas que estabeleceu em suas duas casas. Na do Largo da Matriz é mulher recatada, ficando suas ações destinadas ao jogo de influências políticas, o que fazia como ninguém; na chácara do Jatobá, por sua vez, é mulher sedutora que recebe homens ilustres, ricos, do seu agrado, deles recebendo pequenas fortunas expressas em "presentes" por seus favores:

Essa bipartição residencial é também moral e política. Moral porque distingue um local de festas e encontros sexuais de outro, de residência nãosexualizada. Política porque aponta para um fato até então novo: a distinção de dois espaços em que um é consagrado à relação com pessoas de fora (o Jatobá) e o outro é vedado a essas relações (o palácio na cidade). (Abreu Filho, 1983, p. 102)

Dona Beija, portanto, se apropria de dois papéis, vivendo-os em trajes e cenários a eles apropriados, o que significa que os figurinos e os cenários determinaram, na produção televisiva, a personagem em sua dupla representação (Zola apud Carlson, 1997).

No sobrado do Largo da Matriz, fica clara a permanência da memória melodramática. Quando transformado em palco das muitas cenas nele gravadas, a narrativa passa pela linguagem cênica, a das imagens, valendo-se delas para tornar o ambiente mais expressivo e revelador.

Vasconcelos (1985) contribuiu, com suas minuciosas descrições, para a montagem televisiva do sobrado do Largo da Matriz:

As cortinas ricas, vindas de Lisboa, foram suspensas das portas arqueadas, de cedro rosa. As poltronas fofas de couro legítimo, mesa de jacarandá trabalhada e a cama também de jacarandá, com [dossel] verde-musgo, foram colocadas no palácio de Bêja. (...) O chão de tábuas de bálsamo, largas, de palmo, conforme uso, desapareceu nos tapetes estrangeiros. (...) No salão de visitas o lustre da Boêmia pendia, faiscando cristais móveis. (...) Da maneira que Bêja acomodou ali sua mudança, tudo ficou em boa ordem. (p. 188) 
Não houve intenção de cópia fiel por parte da produção de Dona Beija. Entretanto, o que se percebeu foi a intenção de manter a atmosfera do ambiente que circundou Bêja no romance. Na sala ou no quarto de Beija, a caracterização é corretamente indicada e vemos, ao lado de um luxo moderado, um gosto por efeitos exagerados na cor ou na proporção das peças que compõem os espaços onde a personagem se situa com certa relutância. De qualquer forma, o que se queria marcante assim ficou: no sobrado Dona Beija se impõe como principal figura local, atuando com recato ao receber suas desinteressadas visitas masculinas, amigos que não a abandonaram em nenhuma circunstância. Sempre impecável em seus figurinos de época, próprios ao decoro do local, porém insinuantes na simplicidade de suas linhas, é no sobrado que Dona Beija revela seu lado "bom”, construído entre cortinas esvoaçantes e cristais cintilantes.

Diferentemente do sobrado do Largo da Matriz, o interior da chácara do Jatobá não interessou nem a Vasconcelos, nem a Leonardos. Talvez porque no Jatobá as ações fossem mais eloqüentes e Dona Beija mais envolvente. O certo é que somente os frutos do pomar do Jatobá foram registrados:

\begin{abstract}
Mudas vindas, como presentes, ostentavam frutos de ouro. Jabuticabeiras de copas altas, sem galhos no liso tronco, vicejavam com seivoso vigor. Mangueiras de Ouro Preto e S. João del Rei arqueavam-se de frutos de polpa delicada. Bêja colhia mate vindo do Jardim Botânico da Capital das Minas, tão bem quanto o inglês de Ceilão. (...) As parreiras vindas de Paracatu produziam, como lá duas vezes por ano. Não eram uvas pequenas e ácidas, mas, graúdas, coradas e sumarentas... (Vasconcelos, 1985, p. 249)
\end{abstract}

Vasconcelos não pára por aí e continua mostrando os arredores em suas potencialidades naturais, o suficiente, para ele, em sua caracterização do Jatobá.

Ao quadro campestre, Leonardos (1986) acrescentou sem, no entanto, descrever: "perfumes de França, tecidos de seda e veludo, cristais da Boêmia, espelhos de Veneza (...) livros, gravuras, quadros, móveis, louças chinesas, de Macau e da Companhia das Índias...” (p. 97)

Assim sendo, vê-se que Vasconcelos e Leonardos não foram cogitados pela produção da telenovela quando essa se empenhou na criação da chácara do Jatobá. Podemos, por outro lado também supor ter ocorrido o mesmo que nos romances, ficando a cena reservada a Dona Beija e ao seu total domínio da situação (no mínimo estranhável), de ser apenas ela, na chácara do Jatobá, a disputar as atenções masculinas para, ao final, escolher em público o eleito para sua cama.

Continuando nossa análise dos cenários, percebe-se que no salão onde ocorriam as reuniões, ou mesmo no movimentado quarto de Beija, são permitidas liberdades de estilo e de 
época sem uma preocupação real com o efeito da medida no desempenho de Beija, ou até com a impressão pouco confortável causada no espectador pelos excessos de cores, texturas e formas distribuídas em quase nenhum aparato cênico significativo. Ao sermos conduzidos ainda para esse mesmo salão da chácara do Jatobá, nosso olhar é atraído para o centro da cena, onde um enorme sofá redondo, vermelho, marca invariavelmente as aparições de Beija que nele sentada ou nele de pé (dançando) personifica a imagem da desordem, a ameaça permanente às mães de família e aos bolsos de seus maridos. (Abreu Filho, 1983). O Jatobá, conclui Abreu Filho, "é o local onde D. Beija exerce sua supremacia, onde executa sua vingança e de onde retira sua força e sua riqueza" (p. 90). Exatamente por ser o local destinado ao cumprimento de objetivos tão complexos, os quais exigem, em sua realização, vontade e obstinação férreas da personagem e, assim, um desempenho exemplar da atriz, colocaram-se de lado as possíveis contribuições que o cenário da chácara do Jatobá pudesse oferecer à construção da personagem Dona Beija.

Enfim, para o público, a imagem de Beija estava a essa altura confirmada pelo já visto, nos muitos capítulos apresentados e na história contada pela música-tema de Beija. Ouvida diariamente na exibição da telenovela e nas paradas de sucesso das rádios de todo o Brasil, ela fixava na memória do ouvinte o que a ele estava reservado nos próximos capítulos da novela e também a nós antes de passarmos ao terceiro momento do $1^{\circ}$ Ato de Anos de Ouro.

Beija flor, Beija menina Quem a fez assim tão divina Quem a fez tão bela e tão fera Chuva e sol de primavera

Senhora de tantos amores A dama de Araxá Por ela sonham os homens Quem a Beija beijará

Senhora também das dores Do povo de Araxá Por ela sofrem os homens Quem a Beija vai desprezar

Que mistério, basta um olhar Ela vai nos enfeitiçando Todo o homem perde o rumo

E se entrega ao seu domínio Que poder terá essa tal mulher Com seu doce mortal veneno Ela ama, ela odeia

Mas não sei se ela é feliz

(Wagner Tiso e Viva $\mathrm{Voz}^{80}$ )

\footnotetext{
${ }^{80}$ (Tema de Dona Beija - http://www.teledramaturgia.com.br/donabei.htm).
} 


\section{A CONQUISTA AMOROSA DE BEIJA (Cenas 87 a 102)}

A trama amorosa foi tecida capítulo a capítulo da novela Dona Beija e, nesse espaço dedicado à conquista amorosa, assim denominada para ressaltar o peso que representou na narrativa televisiva a presença tumultuada de Antônio Sampaio na vida de Beija. Daremos destaque ao valor atribuído ao caso sentimental apontado, na recuperação do passado proposta pelo gênero "novela de época".

No caso o fundo histórico presente nos textos literários adaptados para a televisão, sofreu o que geralmente ocorre nas versões sucessivas sobre um mesmo tema, perdeu-se diante do arranjo sentimental dado à adaptação das obras biográficas já romanceadas por seus autores Vasconcelos e Leonardos para a televisão.

Mesmo que em Dona Beija tenha havido uma estruturação evidente em torno de características próprias de heroínas que desafiam a cada ação a sociedade a que pertencem, sendo timoneiras de seu próprio destino, a novela não deixou de representar um campo fértil para a inclusão de um romance definitivo, o de Beija e Antônio, responsável direto pelos dramas de seus protagonistas.

Nessa perspectiva podemos aproximar mais uma vez a telenovela Dona Beija do melodrama, na medida em que divide igual interesse pelos enredos comoventes e por sua ação "demolidora" na emotividade do espectador.

Quando Beija diz a Antônio que ele poderá vê-la na casa do Largo da Matriz, declara também que estamos entrando num terreno novo, o da realização sentimental, capaz de provocar mudanças impensáveis, mesmo para uma mulher independente como ela.

É nesse território que as surpresas provocadas pelas condições em que se formou o triângulo amoroso (Antônio, Aninha e Beija) pontuam a narrativa que se faz ágil. Salteiam os dramas das duas mulheres em suas posições absolutamente desiguais, e somos forçados a ora sofrer com uma, ora com outra, desejando que as duas liquidem com o machismo e a ambigüidade do galã, Antônio Sampaio, representado na televisão por Gracindo Júnior.

Se na dramaturgia televisual a escrita dramática recorre às normas do folhetim, vemos no caso de Antônio, a norma que privilegia a facilidade de decodificação do texto televisivo pela utilização de protótipos, que identificam os bons e os maus personagens, em traços mais que conhecidos pelo público em geral.

Antônio Sampaio que no início da exibição da novela era bom, se tornou mau. Gracindo Júnior assim o personificou intensificando, nessa fase de traição conjugal, desmandos com bebida, jogo e irresponsabilidade nos negócios da família Sampaio, as 
“características únicas do seu personagem” (Távola, 1984, p. 77). O ator ganha o espaço necessário para projetar Antônio na dimensão que acreditamos pretendida pelo autor Aguiar Filho, ou seja, suficiente como foco conflitante, porém permitindo, sempre, que Beija mande na cena.

Na sequiência compreendida entre as cenas 87 e 102, regularmente alternadas entre as casas de Beija e a fazenda da família Sampaio, acompanhamos os dramas de Beija e de Antônio num clima de permanente tensão. Nascimento (filho de Aninha), gravidez (de Beija), desconfiança (Beija tem muitos homens), mágoa (de Beija e de Aninha), tentativa de suicídio (irmã de Antônio), encontro (Beija e Aninha), separação (Antônio e Beija), delineiam a curva dramática mostrando ao final um rompimento que sabemos temporário e causador dos conflitos que movimentarão os próximos capítulos. Importa ressaltar que Gracindo Júnior foi aos poucos, em capítulos anteriores a essa sequiência, aprofundando as características que nos fizeram ver o bom e o mau Antônio. Em situações muitas vezes desprovidas de conteúdo dramático apreciável, o ator não permitiu que Antônio perdesse o potencial de interesse que lhe coube na trama amorosa, transformando-se em figura indispensável na trama principal.

Já na primeira semana de exibição da novela Dona Beija a imprensa registrou:

Em Marquesa de Santos, Maitê contracenou com Gracindo Jr., que fazia o papel de Dom Pedro I. Agora, o ator volta aos braços da mesma atriz como o eterno apaixonado Antônio Sampaio. Com a diferença que, livre da pompa imperial, Gracindo está bem melhor. Na primeira semana, ele deu uma boa noção televisiva de como se comporta um homem corroído pela paixão e pela rejeição amorosa: de maneira violenta, alucinada e vingativa. ${ }^{81}$

Antônio anunciou assim, desde o início, sua identidade, sujeita às alterações provocadas por sua paixão por Beija que, não podendo ser evitada, transformou-se no motivo de todos os seus males fazendo-o transitar entre a falha moral e a desgraça. Na cena 97, Antônio deixa claro que sua intenção é oposta ao que diz. Embora afirme que não voltará para Beija sabemos que o fará, assim como também sabemos que será este o motivo da sua infelicidade e da de Beija.

As cenas seguintes, incluindo a insistência com que visitamos a família Mendonça, o nascimento de Thereza filha de Beija, o retorno de Beija ao trabalho no Jatobá e o seu gesto em aparecer nua no arraial, apontam para sua liberdade e sua autonomia, características que, de alguma forma, sempre acompanharam as atitudes de Dona Beija, na vida real ou na que para ela criaram, quando das suas representações nos mais variados palcos.

\footnotetext{
${ }^{81}$ http://www.fortunecity.com/lavender/tomatoes/792/novelas/donabeija.htm.
} 


\section{$2^{\circ}$ ATO (cenas 103 a 134)}

Observamos a despedida dos dois amantes, Beija e Antônio, sabendo que o fio dessa história permaneceria aberto levando ao agravamento dos problemas e conflitos já existentes. Assim, personagens, enredo e o tempo serão rearranjados no sentido de transpor esse momento em que ocorrem mudanças fundamentais na vida de Beija e de todos que com ela dividem seus dramas.

A mudança da configuração dramática provocada pelo aparecimento de João Mendonça, e as histórias paralelas necessárias à sua inclusão na trama principal, assim como a permanência de Antônio em todas as situações relacionadas a Beija, incluindo o casamento de Thereza (sua filha e de Antônio) e o nascimento de Joana, filha de João, dá seqüência à trama amorosa, tida como ponto de partida para as demais observações que se colocarem como necessárias.

A anunciada retirada de Antônio da cena e da vida de Beija acarretou ao andamento da novela uma estabilidade perigosa. Surge João Mendonça, esperado tanto por sua família como pelos telespectadores continuadamente avisados de sua próxima chegada a São Domingos de Araxá. Ao que parece sua vinda foi antecipada, ao menos em relação ao tempo dos romances, o de Vasconcelos e o de Leonardos. Tal exigência foi provocada pela escrita dramática resultante da adaptação dos textos literários, para a qual a alteração de tempo manteve o ritmo da história. João chegou e de imediato viu Beija que, irresistivelmente nua, o encantou. Nada mais a fazer a não ser acompanhá-la em seus banhos na fonte da Jumenta, em seus raros passeios pelas ruas do arraial, em suas tardes vazias passadas na sala da casa do Largo da Matriz e em seu leito da chácara do Jatobá.

O deslocamento de João na linha do tempo da narrativa televisiva e o entrelaçamento da sua história com a de Beija e a de Antônio não alteraram sua presença insípida e pouco adequada ao temperamento de Beija e ao contexto da novela. Segundo Pallottini (1998), "o personagem existirá se o ator der a ele seu sangue, sua carne; caso contrário não" (p. 144). Assim pensando Marcelo Picchi esvaziou o pouco que restou do João Mendonça dos romances e da história, fazendo de suas ações e falas um arremedo do esperado, pelos espectadores, para o rival de Antônio Sampaio. Mantido porque requerido na trama principal João Mendonça aguarda incomodado pelo desfecho da história, o que o libertará do incômodo e do constrangimento de sua presença em Dona Beija.

Houve certo empenho por parte da direção em acompanhar a evolução do personagem, amparando-a na ampliação da importância do núcleo dramático destinado à família Mendonça, 
onde se desenvolvia o conflito criado pelo estabelecimento da relação amorosa entre Josefa (Maria Izabel de Lizandra), mãe de João, e o maestro Avelino (Jayme Periard), amigo de João. Ao pai de João, José Carneiro de Mendonça (Jonas Melo), presença rara na novela, ficaram reservados um ar melancólico e um triste destino a ser cumprido no próximo ato.

A presença de João Mendonça não deixou de provocar o atormentado Antônio a quem devemos o agravamento dos conflitos reservados à trama principal, traduzidos em suas atitudes tresloucadas que pontuam a narrativa da relação amorosa vivida por Beija e João. Antônio volta aos braços de Beija após o nascimento de Joana, filha dela e de João.

Os dados históricos que permitem a progressão temporal da telenovela, surgem nas muitas discussões que ocorrem entre os freqüentadores do bordel e em anúncios para alistamentos, ou para outros fins, feitos no centro do arraial pela guarda local, cuidadosa em fazer a atualização do tempo. Com isso, podemos circular naturalmente pela casa de Beija, no Largo da Matriz e presenciar os preparativos do casamento de Thereza, sua filha com Antônio. Depois Beija decide recuperar sua liberdade: Antônio não mandará nem em sua casa, nem em sua vida.

\section{$3^{\circ}$ ATO (Cenas 135 a 178)}

Na trama da novela Dona Beija pudemos perceber a importância dada à busca da realização amorosa que pontua a sua vida. Sendo batalha difícil para uma heroína de moral duvidosa, quer pelo sem número de obstáculos que entre ela e seu ideal se interpõem, quer pelo seu temperamento sempre a lhe indicar o caminho da liberdade para a obtenção da felicidade, a busca da realização amorosa tornou-se a linha mestra na sustentação do drama narrado.

Indicamos apenas algumas passagens da vida de Beija que, após serem enriquecidas pela dramatização do texto televisivo encaminham para o momento final de Anos de Ouro, portanto, para a sua resolução, que bem poderia ser o final de Dona Beija.

A questão dominante é a afetiva e se prolonga morosamente na casa do Largo da Matriz, na chácara do Jatobá, na fazenda da família Sampaio, na casa da família Mendonça, seguindo a mesma lógica da história já por nós conhecida. Não nos deteremos nem em Quarentinha, o bandido que invadiu desajeitadamente a cena matando uma das meninas da Casa da Candinha da Serra e o pobre do pai de João Mendonça (que por não ter melhor papel na trama foi assim eliminado), nem tampouco em acontecimentos que obedeceram a ordem 
natural das coisas. Observaremos diretamente Beija, a Beija que “(...) seduz, gera e mata, literalmente no caso de Antônio e simbolicamente no caso de João Carneiro" (Abreu Filho, 1983, p. 90).

Colocamo-nos ao lado de Antônio e de João e deixamos Beija passar ao largo. Não nos dispusemos a observá-la sistematicamente como, até então, fizemos. Cabe, portanto, perguntar: e a Beija, essa que agora anunciamos como sedutora e assassina? Como ficou a personagem que encaminhará as ações em suas resoluções finais?

À Beija vítima e sedutora ajuntaram-se a prostituta com contornos próximos da mulher libertina e de poucos escrúpulos, e a mulher virtuosa, involuntariamente transformada em cortesã, pelas circunstâncias do rapto inicial e da conseqüente rejeição social. ${ }^{82}$

Embora seu comportamento não tenha deixado de ser desafiador e de Aguiar Filho e Rossano preservarem, na televisão, o único traço permanente do caráter de Beija, o de transgressora de normas, a personagem resvala, em muitas situações, para o indefinido revelando-se pouco convincente, fraca em suas determinações, incompleta em sua configuração. Nem mesmo o recurso cênico representado pelos dois cenários, o do bem, a casa do Largo da Matriz e o do mal, a chácara do Jatobá, contribuiu para transmitir conteúdo mais verossímil. De Beija, Aguiar Filho e Rossano possuíam as indicações biográficas e os fatos romanceados, material suficiente para enriquecer dramaticamente a telenovela, criando trama em que essa mulher independente, ativa, transgressora, às vezes boa e muitas vezes má, ganhasse forma definitiva no universo feminino.

Beija assim ficou: amante indiferente de Antônio e João, mãe postiça de Thereza e Joana, prostituta independente no Jatobá, senhora respeitada no Largo da Matriz e, ainda, transgressora, infeliz e superficialmente má.

Para Maitê Proença, "Dona Beija não era uma personagem maniqueísta: ela amava mas mandava matar quem amava, era libertina na sua vida pessoal mas moralista com as duas filhas, odiava a sociedade vigente e tinha uma escrava como confidente. Foi uma figura apaixonante" (Guanabara, 2006).

Pode ter sido esse o motivo do afastamento entre a Beja verdadeira e a Beija real da televisão. O que poderia ser considerado farto material dramático, utilizável em ações que demonstrassem os efeitos dessa colisão (bem e mal) na determinação do caráter da personagem, não existiu. Cabe recordar as palavras de Pallottini (1989), que bem sintetizam o problema: "Importa, então, finalmente, saber como se vai mostrar o como do personagem" (p. 69).

\footnotetext{
${ }^{82}$ Conforme Capítulo I desta tese.
} 
Vejamos no encadeamento dado aos fatos que se seguem, a Beija agredida que manda matar seus agressores, a Beija má que se revela para sua escrava Severina:

Ouve, Severina, com você eu falo: Eu sou bela só por fora; por dentro sou um demônio. Já tive as mãos duas vezes tintas de sangue: de meu avô e de outra pessoa. Vivendo à força com um poderoso não esqueci meu primeiro amor. Quando voltei, esse amor me pareceu um bálsamo. Ainda pensava que amor valesse alguma coisa... Era uma tola. Todo homem é bruto e egoísta. Por um deles, que me humilhara, me fiz assassina. (Vasconcelos, 1985, p. 339)

Desiludida com as suas tentativas de realização afetiva, Beija, amolada com os ciúmes de Antônio, manda-o embora. Não satisfeita faz com que ele seja atacado pelo seu cão de guarda, motivo que leva Antônio a mandar surrá-la brutalmente, numa emboscada de extrema covardia. Quando se recupera Beija providencia sua vingança contando com a ajuda do Coronel Botelho e de seu poder político, para mandar matar os seus agressores e, posteriormente, com o seu poder pessoal para mandar matar Antônio. Até a morte dos agressores de Beija tudo se passa entre a casa do Largo da Matriz e a fazenda da família Sampaio, sem trégua ou comentário de qualquer natureza, ficando Beija e Antônio expostos ao conflito expresso no confronto de suas vontades, que se avoluma progressivamente.

Nesse ponto da narrativa abre-se nova linha de ação que concorrerá para a intensificação do drama vivido por Beija e Antônio. A trama ganha mais um circunstante inesperado, o maestro Avelino, que ao voltar do Rio para encontrar-se com sua amada (Josefa, mãe de João) adoece e resta a Beija socorrê-lo. João, que não perdoou Avelino, não perdoa Beija por acolhê-lo provocando a separação definitiva entre eles. Dessa forma João é abandonado por Beija. De forma imprevista somos levados à hospedaria onde encontramos Avelino, que nos acompanha à casa de Beija, para em seguida entrarmos na casa da família Mendonça e tomarmos conhecimento do desagrado de João, dali saindo com ele para a casa de Beija em que de forma banal se dá o desfecho, numa cena destituída de emoção. As cenas 158, 159, 160 e 161 aparecem, portanto, independentes em sua configuração, deslocadas no tempo, com o objetivo determinado de aprofundar o drama de Beija, que sem João e sem Antônio, prestes a fechar o Jatobá, com as filhas bem casadas e com as canastras abarrotadas de riquezas, será conduzida conforme o suspense criado para retardar a solução do problema.

Não sabemos como será o fim. Porém, um escravo que rouba um diamante e foge de Paracatu do Príncipe é o primeiro de uma série de indícios, que se encarregarão de manter a tensão da trama, responsável pelo envolvimento do espectador.

Depois de idas e vindas entre a casa do largo da Matriz e a fazenda da família Sampaio, os personagens se encarregaram de nos fornecer os dados que alimentam nossas 
conjecturas. Beija contrata Ramos para matar Antônio, o que ele faz. Nos livros Ramos mata Antônio na taberna do arraial; na televisão, na fonte da Jumenta, elemento unificador da história de amor vivida pelos protagonistas, Beija e Antônio.

Ao fim, Beija é avisada e, desesperada, chora ao lado de Aninha e de toda a família Sampaio em cena patética montada no quarto da fazenda, retirando-se a pedido da mãe de Antônio. Nesse gesto de dor e indignação perante a morte do filho, Da. Ceci reafirma a extensão do abandono e da rejeição de Beija por de São Domingos de Araxá, expresso, anteriormente, no casamento de Antônio e Aninha.

Beija se retira cabisbaixa, a família se debruça sobre o seu morto e fecham-se as cortinas.

Teria sido uma boa resolução para o roteiro de Dona Beija. O suspense foi bem montado e mesmo os que já sabiam o "fim", foram envolvidos pela expectativa criada a partir do roubo do diamante, praticado por Ramos, em Paracatu do Príncipe.

Não foi esse o final. Ramos foi preso e, torturado, confessou que foi Beija a mandante do crime. Novamente abrem-se as cortinas e o conflito instaurado vai se desdobrar numa outra instância, a do possível julgamento de Beija, prometendo mais uma rodada de emoção permanente.

PEREGRINAÇÃO À BAGAGEM (cenas-situação: 179 a 191)

CENA 179 - DELEGACIA - INT. - DIA

Ramos é preso. Torturado confessa: Beija foi a mandante do crime.

CENA 180 - CASA DOS MENDONÇA - INT. - DIA

João, o juiz Costa Pinto e o subdelegado Belegarde conversam. Todos concordam que é preciso proteger Beija. Empenharão os recursos jurídicos e pessoais nessa difícil tarefa.

CENA 181 - CENTRO - EXT. - DIA

Revolução republicana.

CENA 182 - FAZENDA DA FAMÍLIA BOTELHO - EXT. - DIA

Confronto entre liberais e conservadores.

CENA 182 - CENTRO - EXT. - DIA

Intensificação da batalha.

CENA 183 - FAZENDA DA FAMÍLIA SAMPAIO - INT. - DIA 
As mulheres querem socorrer os feridos, porém são comunicadas de que Beija já se encarregou da tarefa.

CENA 184 - CENTRO - EXT. - DIA

A batalha continua.

CENA 185 - CASA DO LARGO DA MATRIZ - SALA - INT. - DIA

João Mendonça fala com Beija sobre o julgamento. A data já foi marcada e será ele o promotor.

CENA 186 - JULGAMENTO - SALA DO JÚRI - INT. - DIA

Platéia repleta. Beija ao lado do assassino, aparenta perfeita tranqüilidade. As muitas fases entre acusação e defesa transcorrem de modo a favorecer a ré.

CENA 187 - JULGAMENTO - CORREDORES - INT. - DIA

No intervalo, os comentários traduzem a opinião geral: Beija é inocente.

CENA 188 - JULGAMENTO - SALA DO JÚRI - INT. - DIA

João Mendonça procede à acusação. De forma velada vai pontuando a retidão de caráter da ré, absolvendo-a de todos os seus possíveis pecados. Beija é absolvida. Ramos também: matou em legítima defesa.

CENA 189 - CASA DO LARGO DA MATRIZ - SALA - INT. - NOITE

Beija comemora. Muitos amigos presentes. Avelino e Josefa comparecem e se despedem. Vão morar no Rio de Janeiro.

CENA 190 - CHACARA DO JATOBÁ - QUARTO -INT. - NOITE

Beija é surpreendida pelo bandido Quarentinha. Fortunato chega com guardas e o bandido foge. Beija está salva.

CENA 191 - CENTRO - EXT. - DIA

Beija está de partida para a Bagagem. A caravana pára. Padre Aranha, Fortunato e outros correm para se despedir. Momento de grande comoção.

Do passado, a chegada de Beija a São Domingos de Araxá. (FB) ${ }^{83}$.

Do futuro, a legenda se encarrega de redimir a Beija pecadora, e da sua vida na Bagagem, anuncia ter sido coroada de virtudes até o seu fim.

Ao retirar-se da fazenda da família Sampaio, Beija também se retira da vida de São Domingos de Araxá. As cenas se precipitam e passamos ao largo dos fatos históricos, desajeitadamente enxertados na trama (revolução republicana). Preparamo-nos para o julgamento de Beija.

${ }^{83}$ (FB): Flashback. 
Vasconcelos (1985) descreveu, segundo sua imaginação, o julgamento de Beija realizado na Casa do Parlamento, no dia 4 de dezembro de 1837. Ela chegou, "vestida de preto, sem jóias e com os cabelos apanhados na nuca, sem nenhum adorno. (...) Sem atavios, estava tão linda que a multidão se abateu, sempre a seu lado, compadecida de sua sorte” (p. 325).

Tal qual Beija, Maitê Proença foi antecipadamente absolvida ao surgir de negro, na televisão, bela em sua tristeza calculada, obra do dramaturgo que detalhou o estado emocional e psicológico de Beija, distanciando-a da frieza da narrativa histórica. As informações lá estavam em A vida em flor de Dona Bêja. Vasconcelos como bom ficcionista trabalhara os diálogos que compuseram a linha de acusação e defesa da ré. No entanto, foi Aguiar Filho que transformou o julgamento de Beija, na telenovela, em seu momento de purgação, entregandoa ao público, ao final, purificada e pronta para iniciar sua peregrinação à Bagagem.

Vasconcelos (1985) também descreveu:

Chegara cedo o Juiz Costa Pinto que pronunciara a acusada, pela confissão do matador. Não houve testemunhas. Era Promotor de Justiça o Dr. João Carneiro de Mendonça, pai de Joana, cujo marido, Clementino, estava presente. O defensor era um leguleio anônimo de Santo Antônio dos Patos, pois Bêja recusara o oferecimento de muitos que desejaram defendê-la. (p. 325)

E assim aconteceu na telenovela.

A tensão dramática da seqüência que compõe o julgamento é fragmentada numa série de eventos expressivos. Eles vão sendo utilizados, lentamente, para também fechar as linhas das histórias paralelas. Como nos casamentos das telenovelas com final feliz, o autor reuniu na sala de júri todos os participantes da trama, personagens e figurantes. Enquanto a acusação e a defesa simulavam seus papéis, a platéia foi passada em revista pela câmera que nos mostrou o que ainda nos restava saber. As revelações foram feitas com os recursos narrativos adequados aos fechamentos rápidos e pontuais (simples constatação visual de que o tempo passou e pessoas envelheceram, crianças cresceram, imagens de semblantes felizes ou indignados, comentários nos intervalos do julgamento que explicitam situações dos ausentes), geralmente utilizados em últimos capítulos de telenovelas.

Embora em Dona Beija, esse não fosse o último capítulo, a sequiência do julgamento prestou-se ao encerramento das tramas e à glorificação da personagem:

Quando o Dr. Pinto absolveu os réus, em todos os rostos borbulhavam lágrimas de júbilo. Ramos, no naufrágio, conseguiu ganhar a terra, na tábua flutuante de D. Bêja.

Espocaram fogos-do-ar em todos os bairros da cidade. Bêja saiu da Casa do Parlamento sem mais formalidade. Não sorria mas seu júbilo rutilava nos 
olhos molhados. (...) Juiz, Promotor e jurados tiveram convite para um licor no palácio, à noite. (Vasconcelos, 1985, p. 325-327)

Foi adiado para esta ocasião o fechamento da história da família Mendonça, encerrada na despedida de Josefa (mãe de João) e Avelino, que comunicam a Beija sua próxima partida para o Rio de Janeiro.

Nada mais a ser revelado já que em Dona Beija, drama histórico-biográfico, o fim é por todos suspeitado, a história tropeça na reaparição do bandido Quarentinha e nos preparativos de Beija para partir.

Bagagem é o seu destino e conforme Vasconcelos (1985), de quem Aguiar Filho ficou mais próximo ao encaminhar o último capítulo, Bêja teria dito: "Paguei meus erros com o ferro em brasa do mais firme arrependimento. A Bêja de ontem não é mais a de hoje. Graças a Deus recolho-me em tempo, ainda rica e bela, o que é visível, a uma vida modesta, vida de lar que nunca tive" (p. 347).

A Beija da televisão deixa a tela cercada de emoção, a da despedida de São Domingos de Araxá e a dos espectadores para os quais se tornou inesquecível.

Aguiar Filho decidiu o corte final e o fez no momento em que o futuro de Beija não anunciava nenhuma passagem que merecesse ser dramatizada, ao menos para a televisão. 
A TELENOVELA DONA BEIJA: tradução cultural no universo do senso comum

Ao utilizar um empréstimo, o artista apenas traduz o sentimento que lhe foi transmitido por uma obra de arte anterior, e é por isso que toda obra, se tomar de empréstimo um argumento, ou mesmo cenas, situações ou descrições, é tãosomente um reflexo da arte, um simulacro, mas não a arte ela mesma.

Liév N. Tolstói 
Se considerarmos o objeto de estudo proposto no projeto da tese de doutorado, acompanhar a vida de Anna Jacintha de São José, Dona Beja, em seu contexto histórico e na transposição para a produção televisiva, podemos dizer que projeto e tese finalizaram. Porém, se levarmos em consideração a maneira como se deu nossa aproximação com Dona Beja, sabendo das muitas formas como outros já o fizeram, e de outras mais, diríamos que nosso projeto foi realizado e o resultado apresentado na forma dessa tese de doutorado.

Durante o tempo em que a Beja nos dedicamos, estabelecemos com ela além de compromisso acadêmico, portanto, de caráter objetivo e racional, uma relação mais delicada, baseada na curiosidade inicial. Tal relação foi, posteriormente, transformada em sentimentos, indo à empatia, sedução, negação, compaixão e ao final, à compreensão, por termos aprendido a apreciar Dona Beja.

Escolhido o percurso de abordagem de nosso objeto: o estudo da personagem real; da memória e sua permanência no processo das muitas traduções culturais feitas da vida de Dona Beja; e a análise das características de construção da telenovela Dona Beija; procuramos percorrê-lo de forma a realizar nosso intuito de aproximação com a personagem histórica e a personagem real de televisão.

Iniciamos mostrando nosso objeto a partir de eventos fundamentais encontrados em registros biográficos de Beja, os quais recolhidos em fontes diversas, possibilitaram-nos apresentar um quadro, uma biografia possível, com traços e contornos da personagem que se veria, mais tarde, transformada em personagem real de televisão.

Dessa imagem, a de Anna Jacintha de São José (Dona Beja): uma biografia possível, caminhamos para os componentes essenciais de Dona Beja, na condição de uma história de vida, aqui sujeita aos caprichos da memória, confrontados com os elementos da historiografia. Esse trecho, ou capítulo sugere o que identificamos como uma passagem da memorialística histórica. Durante a sua elaboração observamos as primeiras variações sobre o tema, criadas na difícil tarefa de "captar o passado", aqui registrada na Tradução cultural de Beja: história e memória.

Terminada a primeira parte do estudo - compreendendo os dois primeiros capítulos que a princípio nos parecia de fácil acesso, percebemos sua importância do ponto de vista histórico-cultural. Essa importância pode, também, ser associada ao grau de dificuldade presente em sua realização, e ao grau de realização pessoal e intelectual a nós proporcionada.

Sobrevêm então, na segunda parte - compreendo os dois últimos capítulos -, as dificuldades próprias ao acompanhamento da construção e interpretação de uma personagem, Dona Beja, na tradução cultural dela feita em diferentes épocas e linguagens. Tal 
acompanhamento exigia-nos considerações sobre as condições histórico-culturais em que ocorreram as traduções e sobre as características estilísticas de seus autores. Estendemos nossa busca ao tempo compreendido entre a Beja de Totinha e a Dona Beija da televisão e também ao tempo passado antes de Totinha. Pudemos então anotar em A construção $e$ transfiguração da personagem Dona Beja: na pintura, no teatro, no romance e no carnaval, a variedade de papéis representados por ela, os quais resultaram em pistas indicativas das possibilidades temáticas que se interpuseram entre nós e a Dona Beija, personagem da telenovela exibida em 1986 pela Rede Manchete.

Focalizando o tema fundamental de análise, a história de vida de Dona Beja e sua transposição para a televisão em Dona Beija: personagem real de televisão, chegamos às nossas questões iniciais, pautadas na tradução da história de Dona Beja à produção televisiva, com tratamento dos dramas de família e de época.

Portanto, à semelhança de um último capítulo de telenovela, que concentra em seus objetivos o fechamento do que restou de relevante na narrativa, recolhemos os diversos fios que compuseram a trama da nossa história.

Por trazer em seus capítulos as várias traduções de Dona Beja, com momentos, tipos e circunstâncias diferentes desse modelo feminino, compatíveis com visões e condições da sociedade brasileira, antecipamos em cada um deles considerações parciais.

Deixaremos que Dona Beija: personagem real de televisão se encarregue de nossas conclusões finais.

Produzida para atuar sobre a sensibilidade do público a ser conquistado (não nos esqueçamos de que nessa época a Rede Manchete inaugurara recentemente seu núcleo de dramaturgia e investira fortunas nesse projeto), a novela Dona Beija não foi concebida por seus criadores-realizadores com o propósito de se constituir em obra de arte do gênero telenovelesco ou fora dele.

Bastaria que Dona Beija, enquanto novela de época, atingisse o público desejado, tornando-o cativo pelos muitos predicados já vistos e revistos nas cenas-situação, que compuseram o material específico de estudo da telenovela. Por conseguinte, nada que revelasse a intenção própria do artista que, com sua obra, contribui para "modificar uma concepção do mundo, ou seja, para fazer que nasçam novos modos de pensar" ${ }^{\circ 4}$ (Gramsci, 1955, p. 6-7).

\footnotetext{
${ }^{84}$ Tradução para uso desta tese.
} 
Dona Beija, novela bem-sucedida da Rede Manchete, revela o gosto e a ideologia dos repertórios de ficção televisiva seriada, que se integra aos valores impostos pela tradição aos segmentos da sociedade, para quem é previamente destinada.

Em vista disso, apresenta em sua feitura os traços próprios do senso comum, padrão raramente descartado pelas emissoras de televisão, que dependem do mercado pagante (publicidade) e do mercado consumidor (público). Para esses mercados, o senso comum rege a aceitação e o sucesso da empreitada.

$$
* * *
$$

Com a finalidade de demonstrar os comandos e as incorporações do senso comum na telenovela Dona Beija, utilizamo-nos de cenas recortadas da telenovela e editadas no DVD que acompanha este estudo. Dois foram os nossos motivos para assim proceder.

O primeiro tem a ver com a seleção das cenas que, por seu conteúdo, nos pareceram exemplares; o segundo seria o de subsidiar com imagens as observações pensadas para compor esta conclusão. Vejamos primeiro as cenas e após os comentários:

i. Partida de Beija para a Bagagem e sua relação com diamante maior do que o lá achado antes, o diamante "Estrela do Sul";

ii. A riqueza como antídoto da desgraça causada pelo rapto, segundo o padre;

iii. O uso do ritual africano na maldição da mão porca do homem;

iv. A honra e a coragem da Lady Godiva transfiguradas em desonra e em autonomia individual por Dona Beija. A expressão de compromisso de Lady Godiva na defesa da sociedade, transformada em ato pessoal com caráter de desforra de Dona Beija, contra a cidade que não a acolheu depois e não a desculpou;

v. O julgamento do homicídio de Antônio Sampaio, no qual Dona Beija apresenta o álibi em sua defesa: no dia decidira fechar a chácara do Jatobá, por cansaço da vida fácil; segundo ela, como diziam.

$\mathrm{Na}$ tradução feita das cenas acima mencionadas podemos ainda destacar as seguintes inversões:

- riqueza e diamante solucionam rapto, morte do avô, desonra e rejeição individuais; 
- a maldição da mão porca do homem identifica-se com o álibi da defesa de Beija no julgamento, com o fechamento do prostíbulo e o cansaço da vida fácil, como ela mesma declara;

- troca da nudez honrada e corajosa de Lady Godiva, fruto de compromisso social, pela nudez vingativa e pessoal de Dona Beija, que enfrenta a maldição da mão porca do homem através do seu poder ilimitado.

Das incorporações do senso comum na telenovela e das conseqüentes inversões assim inscritas em seu resultado, eficazes tanto para manter o público requerido pela emissora como também proporcionar ao próprio público (...) "os mitos messiânicos que mantêm a esperança numa idade maravilhosa onde todas as contradições e todas as misérias presentes acharão sua solução e seu remédio" (Gramsci, 1955, p. 22), podemos concluir que o senso comum cristaliza-se na telenovela Dona Beija.

Como personagem real de televisão, Dona Beija teve de adequar-se aos parâmetros que regulam o uso eficaz dos dramas de família e de época nas telenovelas, regidos por mecanismos capazes de transformá-los em produto de sucesso.

Se assim não fosse, a verdade poderia ter sido o contrário:

- nem a riqueza e o diamante solucionam o rapto, a morte do avô, a desonra e a rejeição individuais;

- nem a maldição da mão porca do homem é tão maldita assim, pois o desejo e as mãos deles a fizeram poderosa econômica e socialmente;

- nem a nudez de Lady Godiva transfere honra à nudez vingativa e particular de Dona Beija.

Como dizia Pier Paolo Pasolini (1997): “o resultado é que toda a felicidade é completamente falsa: que se difunde cada vez mais e mais uma imediata infelicidade" (p. 54).

E, o certo é que a Beja hoje existente, ou melhor, a que é lembrada para além das fronteiras do Triângulo Mineiro e da memória familiar, é a Dona Beija da Rede Manchete. 
ABREU FILHO, Ovídio de. Dona Beija: análise de um mito. In: FRANCHETO, Bruna et al. (Orgs.). Perspectivas antropológicas da mulher. Rio de Janeiro: Jorge Zahar, 1983.

ABREU, Regina. A fabricação do imortal: memória, história e estratégias de consagração no Brasil. Rio de Janeiro: Rocco, 1996.

ALBERTI, Leon Battista. Da pintura. Campinas: Editora da UNICAMP, 1989.

ALENCAR, Edgar de. O carnaval carioca através da música. $3^{\mathrm{a}}$ ed. Rio de Janeiro: INL, 1979.

ALENCAR, Mauro. A Hollywood brasileira: panorama da telenovela no Brasil. $2^{\text {a }}$ ed. Rio de Janeiro: Ed. Senac Rio, 2004.

ALMEIDA, Jane Soares de. Mulher e educação: a paixão pelo possível. São Paulo: UNESP, 1998.

ALMEIDA, J.G. O sertão dos Araxás e os amores de Dona Beija. $2^{\text {a }}$ ed. São Paulo: J. Bignard \& Cia., 1967.

ALMEIDA, Milton José de. A educação visual da memória: imagens agentes do cinema e da televisão. Pro-posições. Campinas: v. 10, n. 2, julho/1999.

. Cinema Arte da Memória. Campinas, SP: Autores Associados, 1999.

O teatro da memória de Giulio Camillo. Cotia: Ateliê Editorial; Campinas: Editora da Unicamp, 2005.

ALVIM, Maria Lúcia. Romanceiro de Dona Beja. Rio de Janeiro: Fontana; Brasília: INL, 1979.

APOLINÁRIO, Célio. Teatro - Dona Beija. Veja. 29/10/1980. São Paulo.

ARISTÓTELES. Poética. $6^{\text {a }}$ ed. Rio de Janeiro: Imprensa Nacional, 2000.

BALOGH, Anna Maria. Conjuncões, disjunções, transmutações. Da literatura ao cinema e à TV. São Paulo: Annablume; ECA/USP, 1996.

O discurso ficcional na TV: sedução e sonho em doses homeopáticas. São Paulo: EDUSP, 2002.

BARBOSA, Maria Clarete. A participação da mulher na história de Minas. Belo Horizonte: Imprensa Oficial, 1986.

BARROS, Flávio Pereira. Estrela do Sul: uma viagem no tempo. Estrela do Sul: Independente, 2003. 
BAXANDALL, Michael. Padrões de intenção: a explicação histórica dos quadros. São Paulo: Cia. das Letras, 2006.

BENJAMIM, Walter. A obra de arte na era de sua reprodutibilidade técnica. In: Obras escolhidas: magia e técnica, arte e política - Vol. 1. São Paulo: Brasiliense, 1985, p. 165-96.

BORELLI, Sílvia H. S.; ORTIZ, Renato; RAMOS, José Mário Ortiz. Telenovela: história e produção. São Paulo: Brasiliense, 1989.

BORGES, Vavy Pacheco. O historiador e seu personagem: algumas reflexões em torno da biografia. Horizontes, Bragança Paulista: v.19, p. 01-10, jan./dez., 2001.

BOSI, Ecléa. Memória e sociedade: lembranças dos velhos. $3^{\text {a }}$ ed. São Paulo: Cia. das Letras, 1994.

BOTTON, Alain de. Nos mínimos detalhes. Rio de Janeiro: Rocco, 2000.

BOURDIEU, Pierre. A ilusão biográfica. In: AMADO, Janaína; FERREIRA, Marieta de Moraes (Coords.). Usos e abusos da história oral. Rio de Janeiro: Editora da Fundação Getúlio Vargas, 1996, p. 183-193.

BURKE, Maria Lúcia Garcia Pallares. Nísia Floresta, o Carapuceiro e outros ensaios de tradução cultural. São Paulo: Hucitec, 1996.

BURKE, Peter. Variedades da história cultural. Rio de Janeiro: Civilização Brasileira, 2000.

CALVINO, Italo. As cidades invisíveis. Rio de Janeiro: O Globo; São Paulo: Folha de S. Paulo, 2003.

A palavra escrita e a não escrita. In: AMADO, Janaína; FERREIRA, Marieta de Morais (Coords.). Usos e abusos da história oral. Rio de Janeiro: Editora da Fundação Getúlio Vargas, 1996, p. 139-149.

CAMPAGNAC, Áureo de Souza - Aurinho da Ilha. Dona Beja, a feiticeira de Araxá. http://www.galeriadosamba.com.br. Acessado em 5/5/2007.

CANDIDO, Antonio. A personagem do romance. In: CANDIDO, Antonio et al. A personagem de ficção. $2^{\mathrm{a}}$ ed. São Paulo: Perspectiva, 1970.

CARDOSO, Clodion; AFONSECA E SILVA, Sebastião de. A victima de 1816. Subsídios para a história de Araxá e duas palavras sobre o Triângulo Mineiro. Folhetim publicado de Março a Maio de 1815. Correio de Araxá. Araxá - Minas Gerais.

CARLSON, Marvin. Teorias do teatro: estudo histórico crítico, dos gregos à atualidade. São Paulo: Editora Unesp, 1997. 
CAVALCANTE, Carlos. Como entender a pintura moderna. Rio de Janeiro: Civilização Brasileira, 1963.

CHARTIER, Roger. Os desafios da escrita. São Paulo: Editora UNESP, 2002.

COMTE-SPONVILLE, Andre. Pequeno tratado das grandes virtudes. São Paulo: Martins Fontes, 1995.

CONDÉ, João. Arquivos implacáveis. O Cruzeiro. 12/04/1958. Rio de Janeiro.

COSTA, Antonio. Compreender o cinema. 2a ed. São Paulo: Globo, 1989.

COSTA, Haroldo. Enrêdo 68: dona Beja, a feiticeira de Araxá. O Cruzeiro. 03/02/1968. Rio de Janeiro.

COSTA, Maria Cristina Castilho. A imagem da mulher: um estudo de arte brasileira. Rio de Janeiro: Senac Rio, 2002.

A milésima segunda noite - Da narrativa mítica à telenovela - análise estética e sociológica. São Paulo: Annablume; FAPESP, 2000.

Ficção, comunicação e mídias. São Paulo: Ed. Senac São Paulo, 2002. (Série Ponto Futuro; 12)

COSTA, Waldir Luiz. Da maloca ao palácio. Goiânia: Gráfica Popular, 1987.

CRAVEN, Thomas. Famous artists \& their models. New York: Pocket Books, 1949.

DA SILVA, Maria Beatriz Nizza. Sistema de casamento no Brasil colonial. São Paulo: Edusp, 1978.

DEL PRIORE, Mary (Org.). História das mulheres no Brasil. São Paulo: Editora da UNESP, 1997.

DESTAQUE na Imprensa. Revista Veja (abril de 1986). http://www.fortunecity.com/ lavender/tomatoes/792/novelas/donabeija.htm. Acessado em 14/03/2007.

D’INCAO, Maria Ângela (org.). Amor e família no Brasil. São Paulo: Contexto, 1989.

DORE, Helen. A arte dos retratos. Rio de Janeiro: Ediouro, 1996.

DORNAS, Filho, João. Dona Beija de Araxá. Folha de Minas. Serões de um alfarrabista. 10/3/1942 e 15/3/1942. Belo Horizonte. Arquivo do Museu Dona Beja.

FERNANDES, Ismael. Memória da telenovela brasileira. São Paulo: Brasiliense, 1997. 
FERREIRA, Marieta de Moraes; AMADO, Janaína (Coords.). Usos \& abusos da história oral. Rio de Janeiro: Editora da Fundação Getulio Vargas, 1996.

FIGUEIREDO, Luciano. Mulheres nas Minas Gerais. In: DEL PRIORI, Mary (Org.). História das mulheres no Brasil. São Paulo: Contexto, 1997.

FRIEIRO, Eduardo. A "respeitosa" do Araxá. In: O diabo na livraria do cônego. $2^{\mathrm{a}}$ ed. São Paulo: Edusp, 1981, p. 175-184.

GINZBURG, Carlo. Mitos, emblemas, sinais - Morfologia e história. São Paulo: Cia. das Letras, 1989.

GOMBRICH, E. H. Arte e ilusão - um estudo da psicologia da representação pictórica. São Paulo: Martins Fontes, 1986.

A história da arte. Rio de Janeiro: LTC, 1999.

GRAMSCI, Antonio. Note sul Machiavelli, sulla politica e sullo estato moderno. Torino: Einaldi, 1955. Caderno 22.

GRIFFIN, Susan. O livro das cortesãs: um catálogo de suas virtudes. Rio de Janeiro: Rocco, 2003.

GUANABARA, Beatriz. Chega de clichê e vulgaridade. Entrevista com Maitê Proença. Jornal do Brasil. 19/03/2006. Rio de Janeiro.

HAMBURGER, Esther. O Brasil antenado: a sociedade da novela. Rio de Janeiro: Jorge Zahar, 2005.

Diluindo fronteiras: as novelas no cotidiano. In: SCHWARCZ, Lília (Org.). História da vida privada no Brasil, vol 4. São Paulo: Cia. das Letras, 1998.

HIGGONET, Ane. Mulheres e imagens: aparência, lazer e subsistência. In: DUBY, Georges; PERROT, Michelle (Orgs.). História das mulheres no ocidente. O século XIX. Porto: Afrontamento, 1990, p. 297-349.

HUPPES, Ivete. Melodrama: o gênero e sua permanência. Cotia: Ateliê, 2000.

KOGUT, Patrícia. Record negocia “Dona Beija”. Diário de S. Paulo. 04/02/05. São Paulo.

LA FONTAINE, Jean de. Fábulas de La Fontaine. Belo Horizonte: Itatiaia, 2003.

LAWSON, John Howard. O processo de criação no cinema. Rio de Janeiro: Civilização Brasileira, 1967.

LE GOFF, Jaques. História e memória. 5ª ed. Campinas: Editora da Unicamp, 2003. 
LE GOFF, Jaques; NORA, Pierre (Dirs.). História: novos problemas. $3^{\text {a }}$ ed. Rio de Janeiro: Francisco Alves, 1988.

(Dirs.). História: novos objetos. $3^{\mathrm{a}}$ ed. Rio de Janeiro: Francisco Alves, 1988.

LEONARDOS, Thomas. Dona Beija: a feiticeira do Araxá. $3^{\text {a }}$ ed. Rio de Janeiro: Record, 1986.

LÉVI, Giovanni. Usos da biografia. In: FERREIRA, Marieta de Moraes; AMADO, Janaína (Coords.). Usos \& abusos da história oral. Rio de Janeiro: Editora da Fundação Getulio Vargas, 1996.

LUKÁCS, Georg. A teoria do romance. Lisboa: Presença, s/d.

MACHADO, Arlindo. A televisão levada a sério. São Paulo: SENAC, 2000.

MACHADO FILHO, Aires da Mata; AFONSECA E SILVA, Sebastião de. História de Araxá. Belo Horizonte: Imprensa Oficial do Estado de Minas Gerais, 1946.

MARISE, Júnia e LUIZ, Alfredo. A vida fabulosa de Dona Bêja: romance e aventura numa história real. O Cruzeiro. Rio de Janeiro, 13/11/1965, p. 50-60.

MARCONDES FILHO, Ciro. Televisão, a vida pelo vídeo. São Paulo: Moderna, 1988.

MELLO E SOUZA, Gilda. O espírito das roupas: a moda no século dezenove. São Paulo: Cia. das Letras, 1987.

MELLO E SOUZA, Laura de. Opulência e miséria das Minas Gerais. São Paulo: Brasiliense, 1997.

MEYER, Marlyse. Folhetim, uma história. São Paulo: Cia. das Letras, 1996.

MICELI, Sérgio. Imagens negociadas: retratos da elite brasileira (1920-40). São Paulo: Cia. das Letras, 1996.

MICHELET, Jules. A mulher. São Paulo: Martins Fontes, 1995.

MONTANDON, Rosa Maria Spinoso de. Dona Beja: desvendando o mito. Uberlândia: Edufu, 2004.

MOURA, Carlos Eugênio Marcondes de et al. Retratos quase inocentes. São Paulo: Nobel, 1983.

NOGUEIRA, Lisandro. O autor na televisão. Goiânia: Ed. da UFG; São Paulo: Edusp, 2002.

OLYMPIO, Gonzaga. Uma heroína da Revolução de 1842. Paracatú: O Diário, de 14/4/1942. Museu Dona Beja. Araxá-Minas Gerais. 
ORIEUX, Jean. A Arte do Biógrafo. In: Georges Duby e outros. História e Nova História. Campinas: Unicamp, 1989.

ORTIZ, Renato et al. Telenovela: História e Produção. São Paulo: Brasiliense, 1989.

PALLOTTINI, Renata. Introdução à dramaturgia. São Paulo: Ática, 1988.

Dramaturgia: a construção do personagem. São Paulo: Ática, 1989.

Dramaturgia de televisão. São Paulo: Moderna, 1998.

PASOLINI, Pier Paolo. Cartas luteranas. Madrid: Trotta, 1997.

PORTELLI, Alessandro. A lógica das narrativas e a aprendizagem da diferença na pesquisa de campo. In: WHITAKER, Dulce, VELÔSO, Thelma. (Orgs.). Oralidade e subjetividade: os meandros infinitos da memória. Campina Grande: EDUEP, 2005.

PRADO, Décio de Almeida. A personagem no teatro. In: CANDIDO, Antonio et al. A personagem de ficção. $2^{\mathrm{a}}$ ed. São Paulo: Perspectiva, 1970.

PRIORE, Mary del (Org.). História das mulheres no Brasil. 2a ed. São Paulo: Contexto, 1997.

REIMÃO, Sandra. Livros e televisão: correlações. Cotia: Ateliê, 2004.

REY, Marcos. O roteirista profissional: televisão e cinema. São Paulo: Ática, 1989.

ROSA, Pedro Divino. Dona Beija. $3^{\text {a }}$ ed. Uberlândia: Edição Independente, 1999.

ROSENFELD, Anatol. Literatura e personagem. In: CANDIDO, Antonio et al. A personagem de ficção. $2^{\mathrm{a}}$ ed. São Paulo: Perspectiva, 1970.

O Teatro Épico. São Paulo: Perspectiva, 1985.

ROSSANO, Herval. http://www.hervalrossano.com. Acessado em 14/03/2007.

ROUSSO, Henri. A memória não é mais o que era. In: FERREIRA, Marieta de Moraes; AMADO, Janaína (Coords.). Usos \& abusos da história oral. Rio de Janeiro: Editora da Fundação Getulio Vargas, 1996, p. 93-103.

RUDOLPH, Emmy. Da minha vida. São Paulo: s.n./s.d.

SAINT-HILAIRE, August. Viagem às nascentes do Rio São Francisco. São Paulo: Edusp, 1975.

SAMARA, Eni de Mesquita. As mulheres, o poder e a família. São Paulo, século XIX. São Paulo: Marco Zero; Secretaria de Educação da Cultura, 1989. 
A família brasileira. São Paulo: Brasiliense, 2004.

SARAIVA, Leandro; CANNITO, Newton. Manual de roteiro, ou manuel, o primo pobre dos manuais de cinema e TV. São Paulo: Conrad, 2004.

SESSÃO Nostalgia. Dona Beija. Sinopse. http://www.teledramaturgia.com. Acesso em 04/06/2006.

SCOTT, Joan. História das mulheres. In: BURKE, Peter. A escrita da história. São Paulo: Edusp, 1992.

SOU bisneta de Bêja: Correio de Araxá localiza e entrevista filha de Haydée. Correio de Araxá, Araxá, p. 1 e 6, 28/3/1965.

STIVANIN, Taíssa. SBT compra 'Xica da Silva'. O Estado de S. Paulo. 03/03/05. São Paulo. . 'Xica' faz bem ao Ibope. O Estado de S. Paulo. 24/04/05. São Paulo.

TÁVOLA, Artur da. $O$ ator. Televisão em leitura crítica. Rio de Janeiro: Nova Fronteira. 1984.

.A telenovela brasileira: história, análise e conteúdo. São Paulo: Globo. 1996.

TEIXEIRA, Maria Santos. O solar de Dona Beija. Belo Horizonte: Gráfica Santa Edwiges, 1965.

TISO, Wagner. Tema de Dona Beija. http://www.teledramaturgia.com.br. Acessado em 05/05/2007.

TOLSTÓI, Liév N. O que é a arte? In: CHIAMPI, Irlemar (Coord.). Fundadores da modernidade. São Paulo: Ática, 1991.

VASCONCELOS, Agripa. A vida em flor de Dona Bêja. Belo Horizonte: Itatiaia, 1985.

WILDE, Oscar. Intenções. Rio de Janeiro: Livraria Império, 1957.

WILLIAMS, Raymond. Cultura. Rio de Janeiro: Paz e Terra, 2000.

Cultura e sociedade. São Paulo: Cia. Editorial Nacional, 1969.

XAVIER, Ismail (Org.). A experiência do cinema. Rio de Janeiro: Graal; Embrafilme, 1983.

ZANINI, Walter (Org.). História geral da arte no Brasil. São Paulo: Instituto Walther Moreira Salles, 1983. V. 1 e 2.

ZOLA, Emile. Collection des Ouvres complètes. Paris, s.d., v. XXIII. 


\section{Anexo 1}

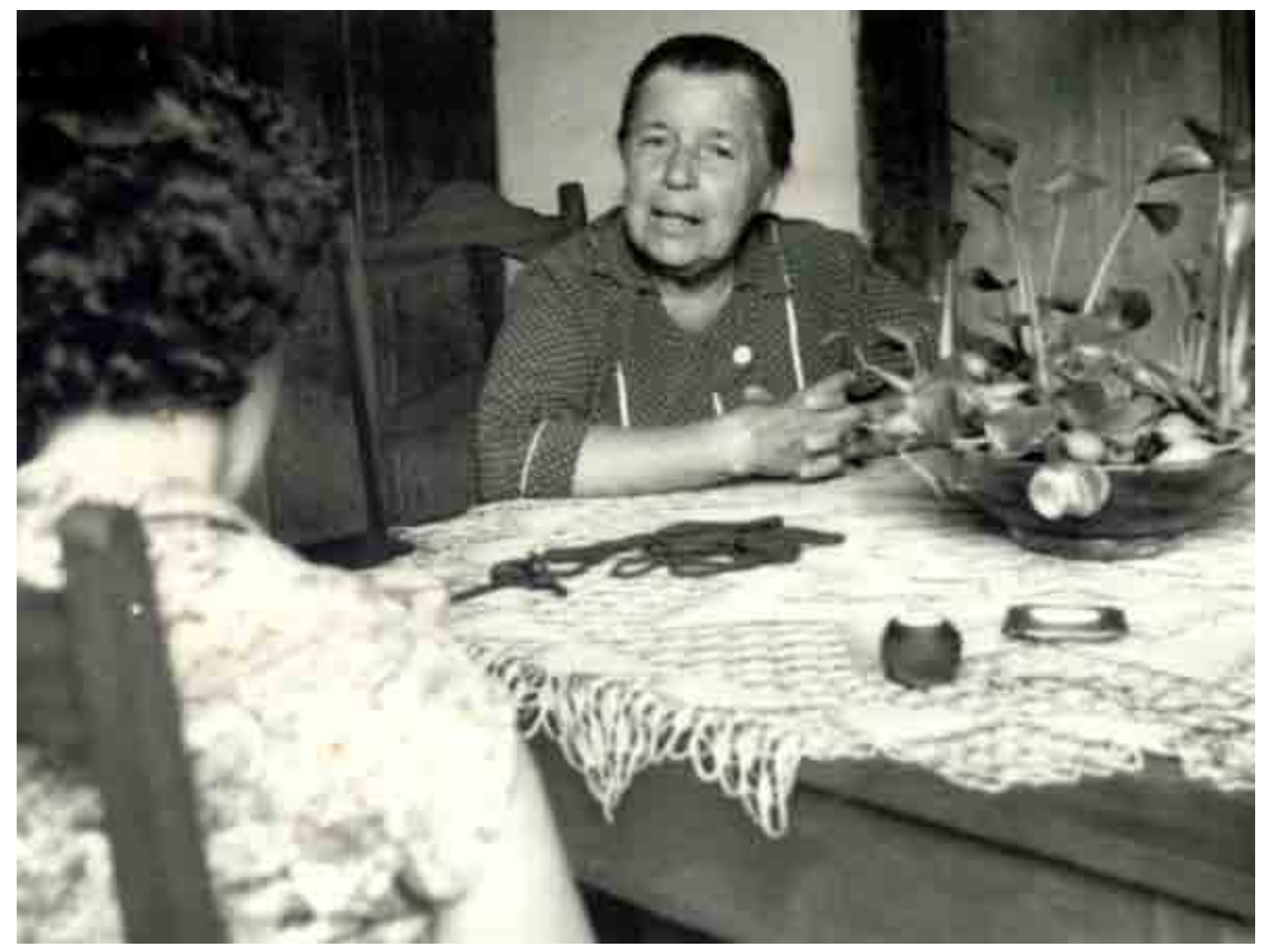

Totinha (Anna de Souza) narrando suas histórias em Estrela do Sul. (Década de 1950 - Arquivo pessoal) 
Anexo 2

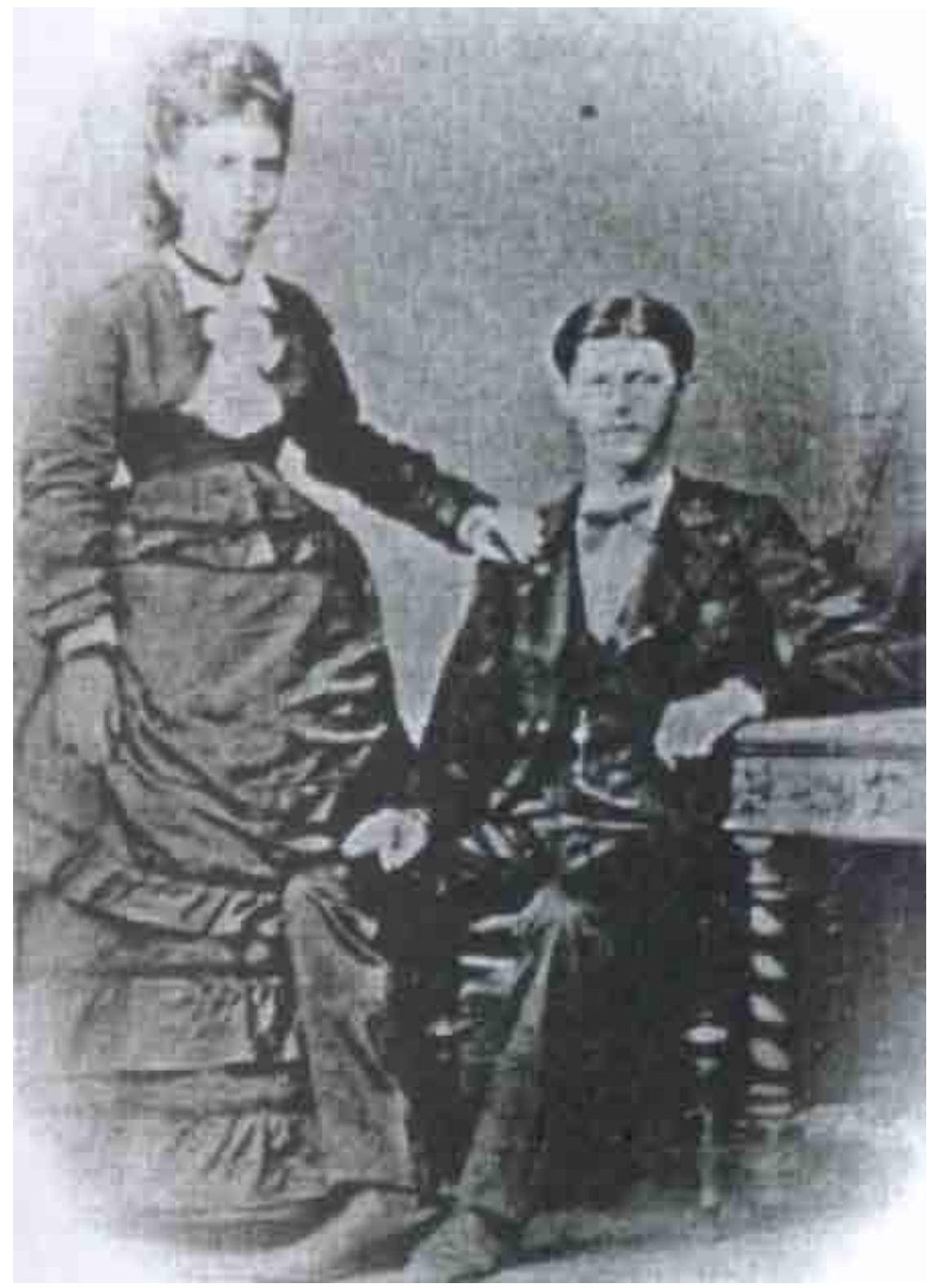

Casal Haydée e José. (Década de 1880 - Arquivo pessoal) 


\section{Anexo 3}

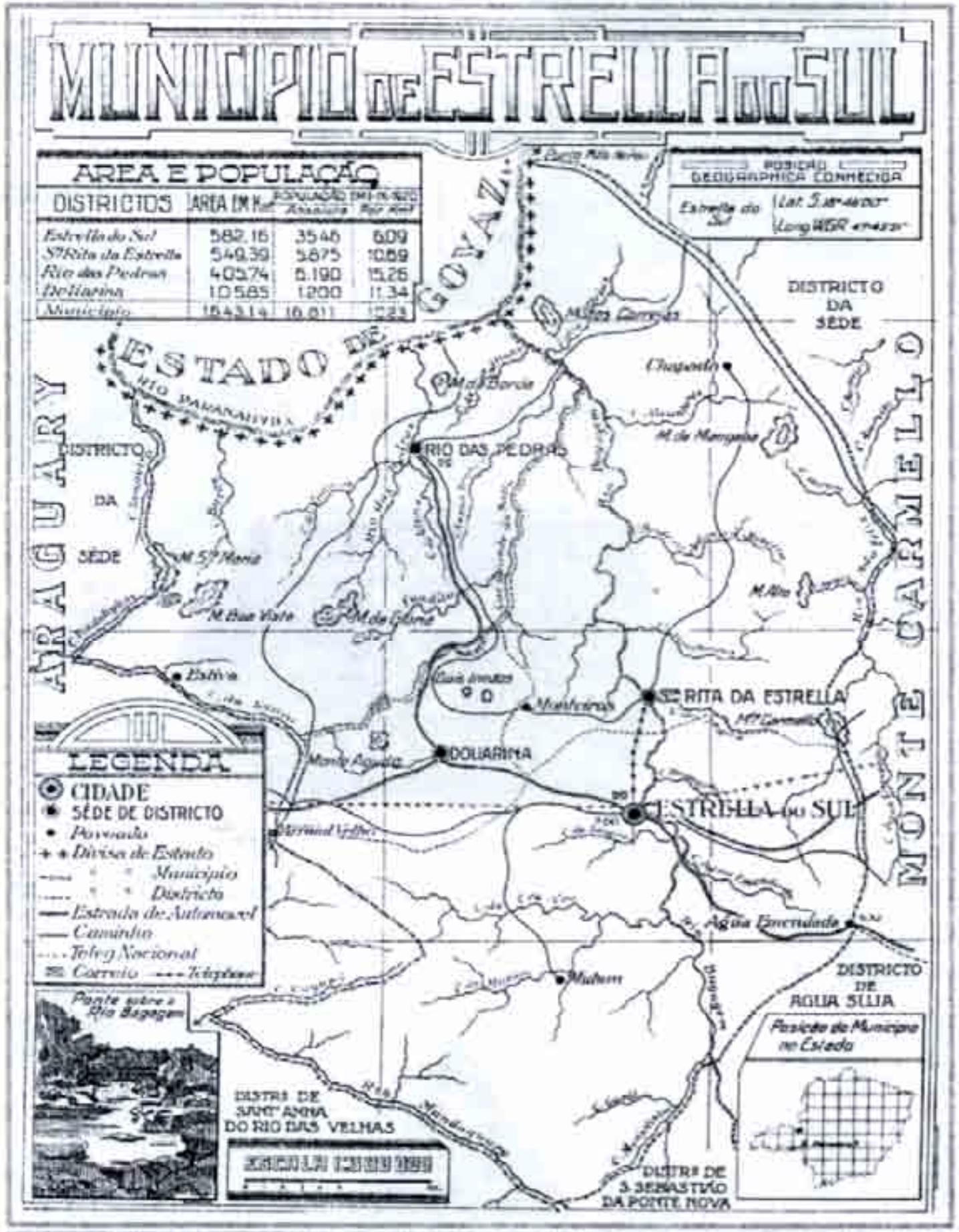

\section{Estrela do Sul-1922}

Mapa do município de Estrela do Sul (Barros, 2003) 


\section{Anexo 4}

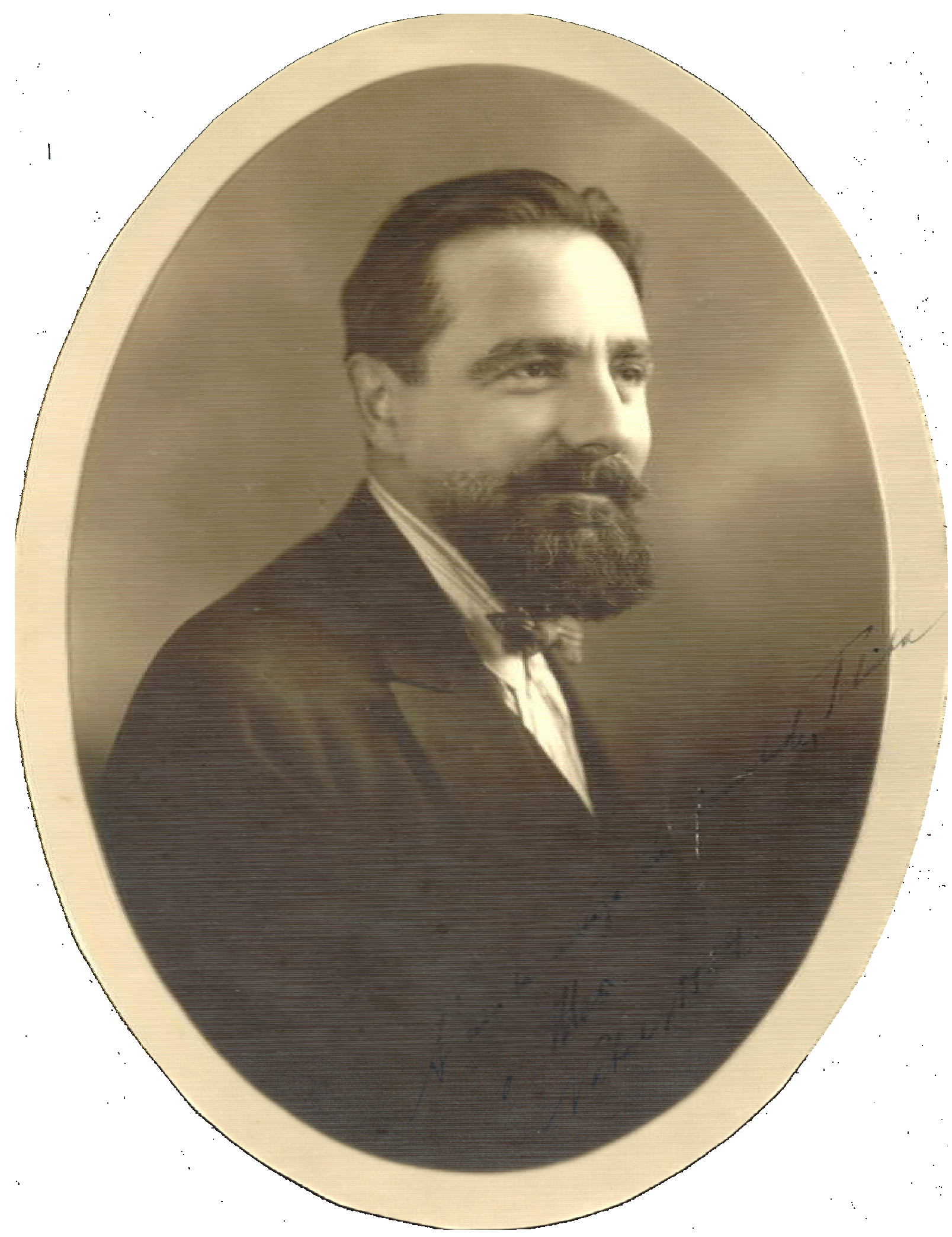

Dr. Max Rudolph (1924 - Arquivo pessoal) 
Anexo 5

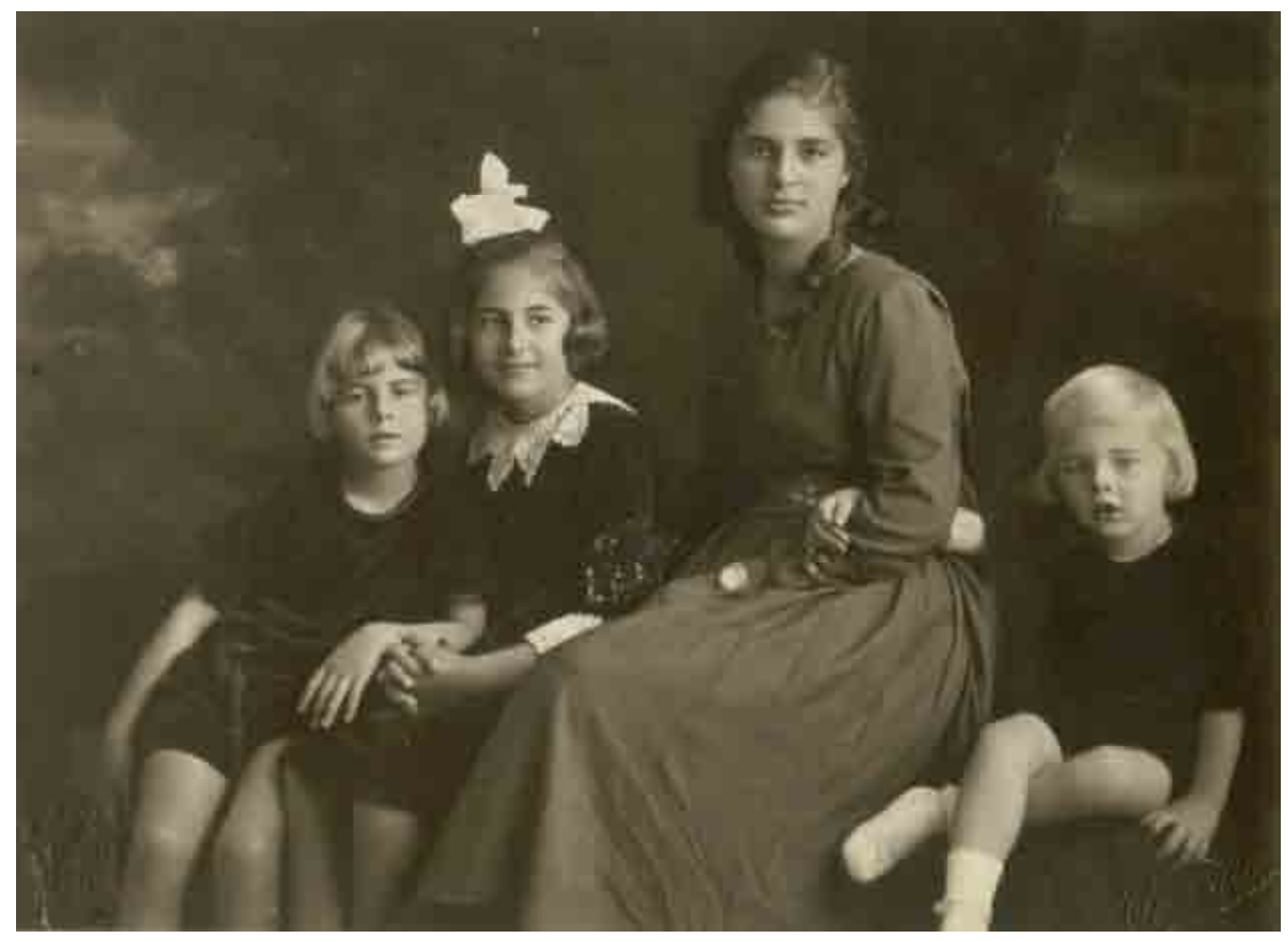

Dona Emmy Rudolph e seus filhos (Década de 1910 - Arquivo pessoal) 


\section{Anexo 6}

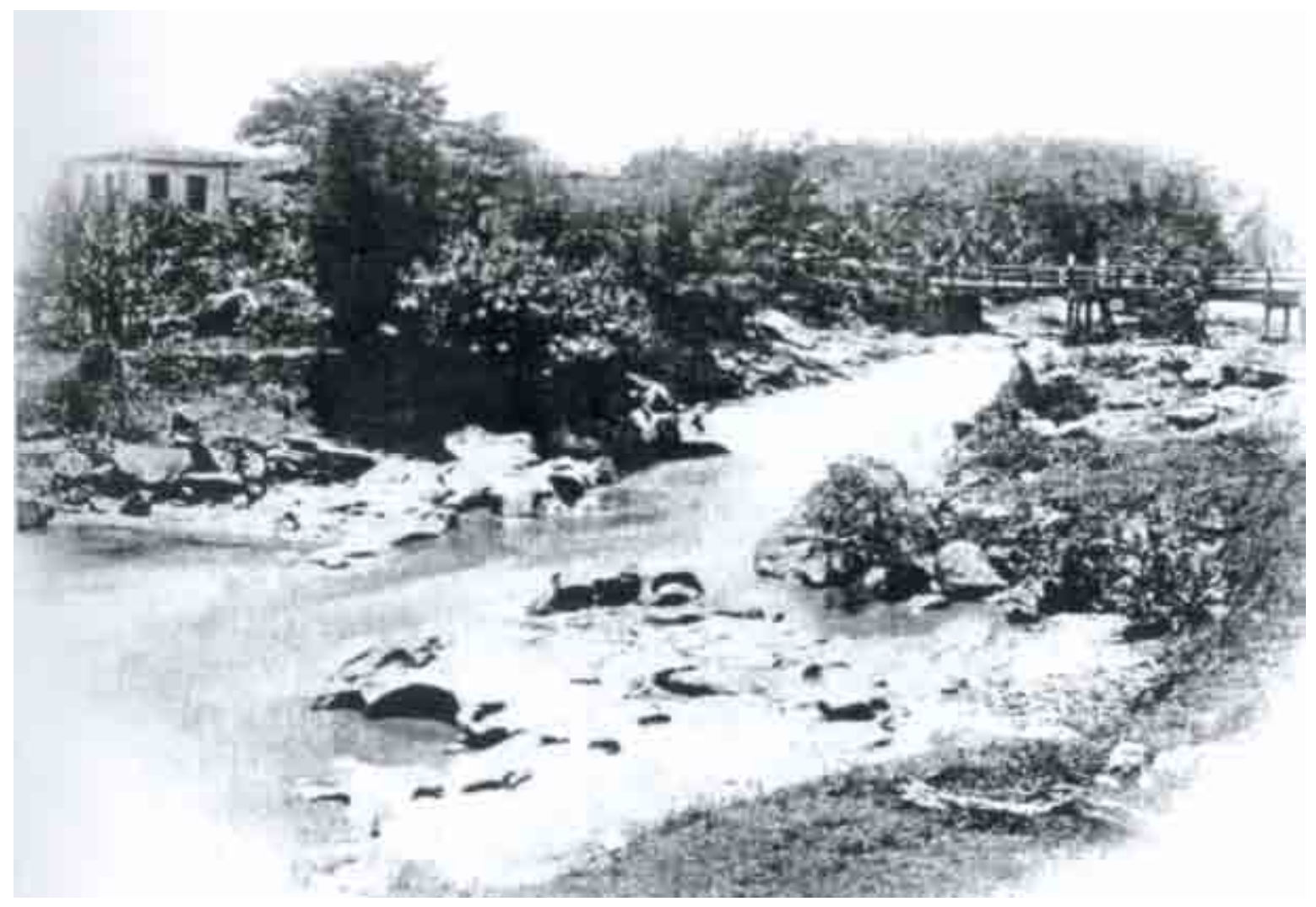

Rio Bagagem (Barros, 2003) 


\section{Anexo 7}

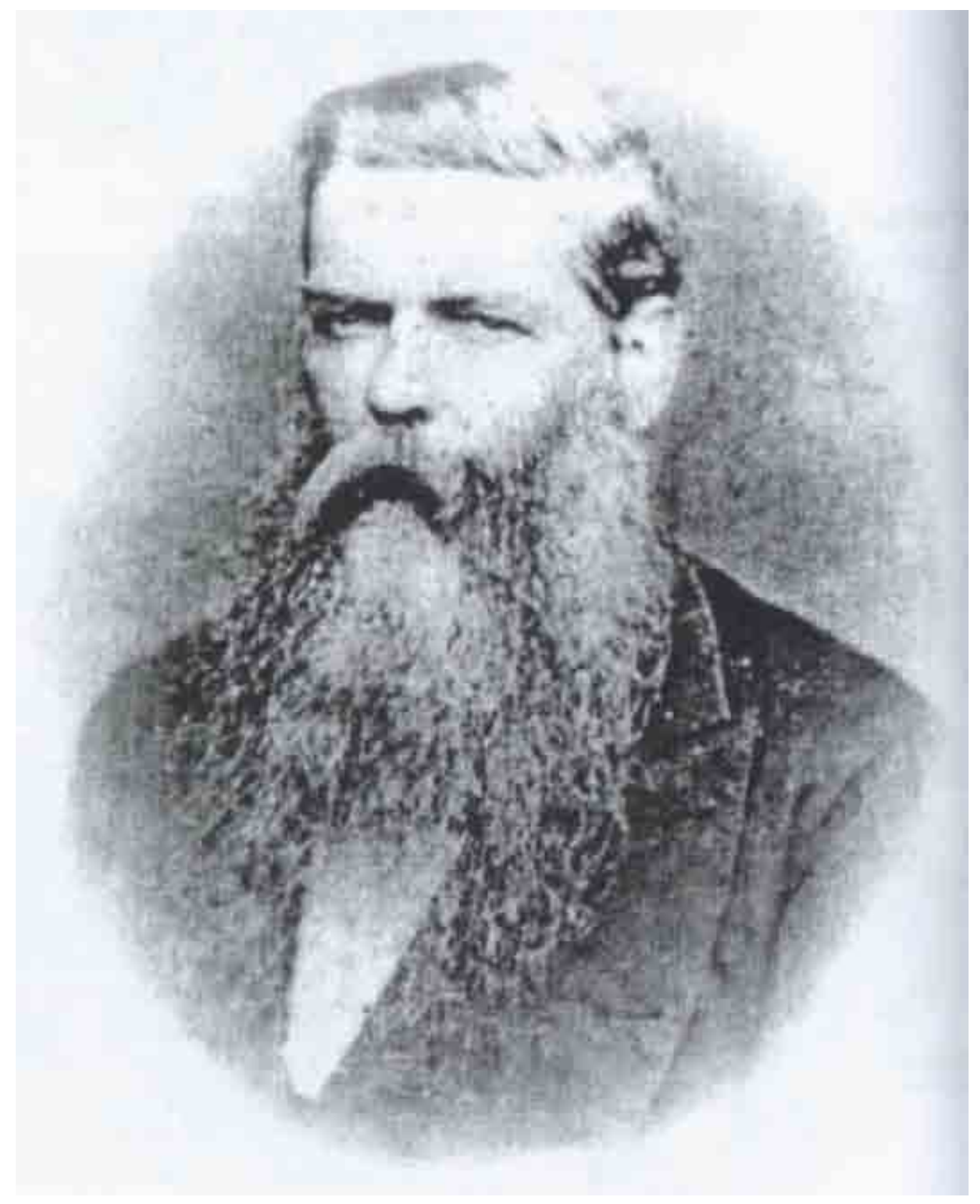

Clementino Martins Borges (Década de 1880 - Arquivo pessoal) 


\section{Anexo 8}

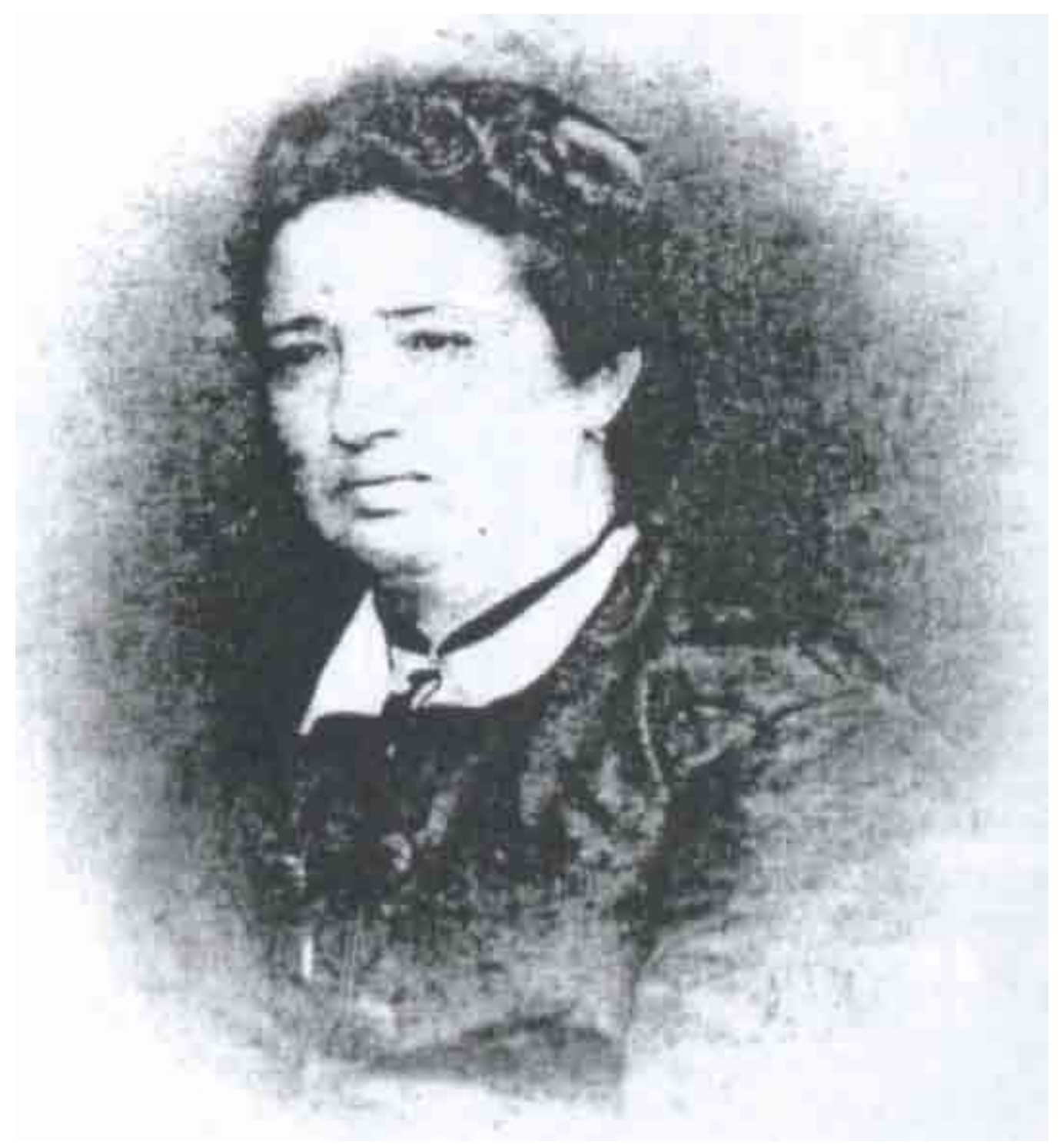

Joana de Deus São José (Década de 1880 - Arquivo pessoal) 
Anexo 9

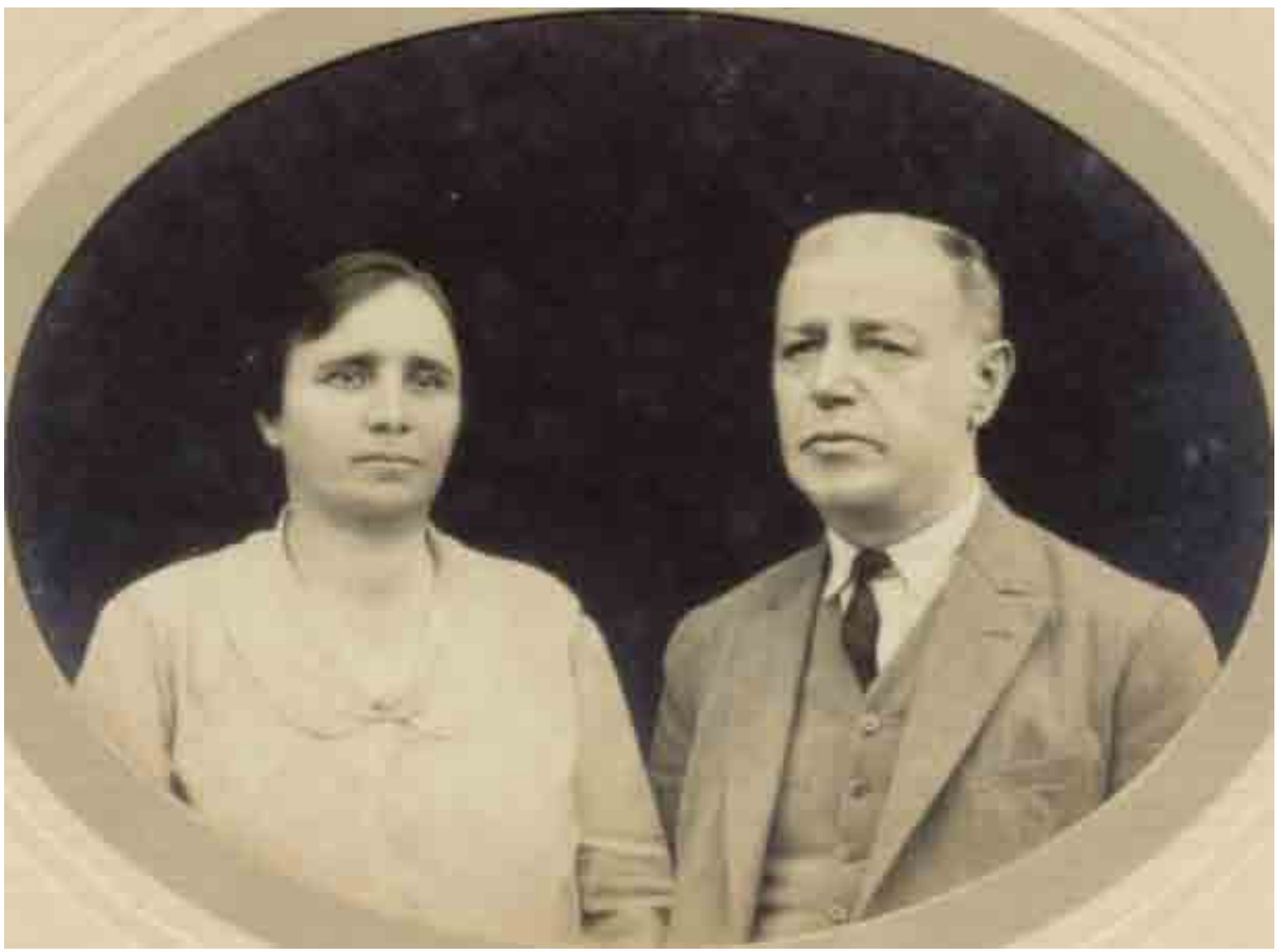

Eulina e Genésio de Souza (Década de 1940 - Arquivo pessoal) 
Anexo 10

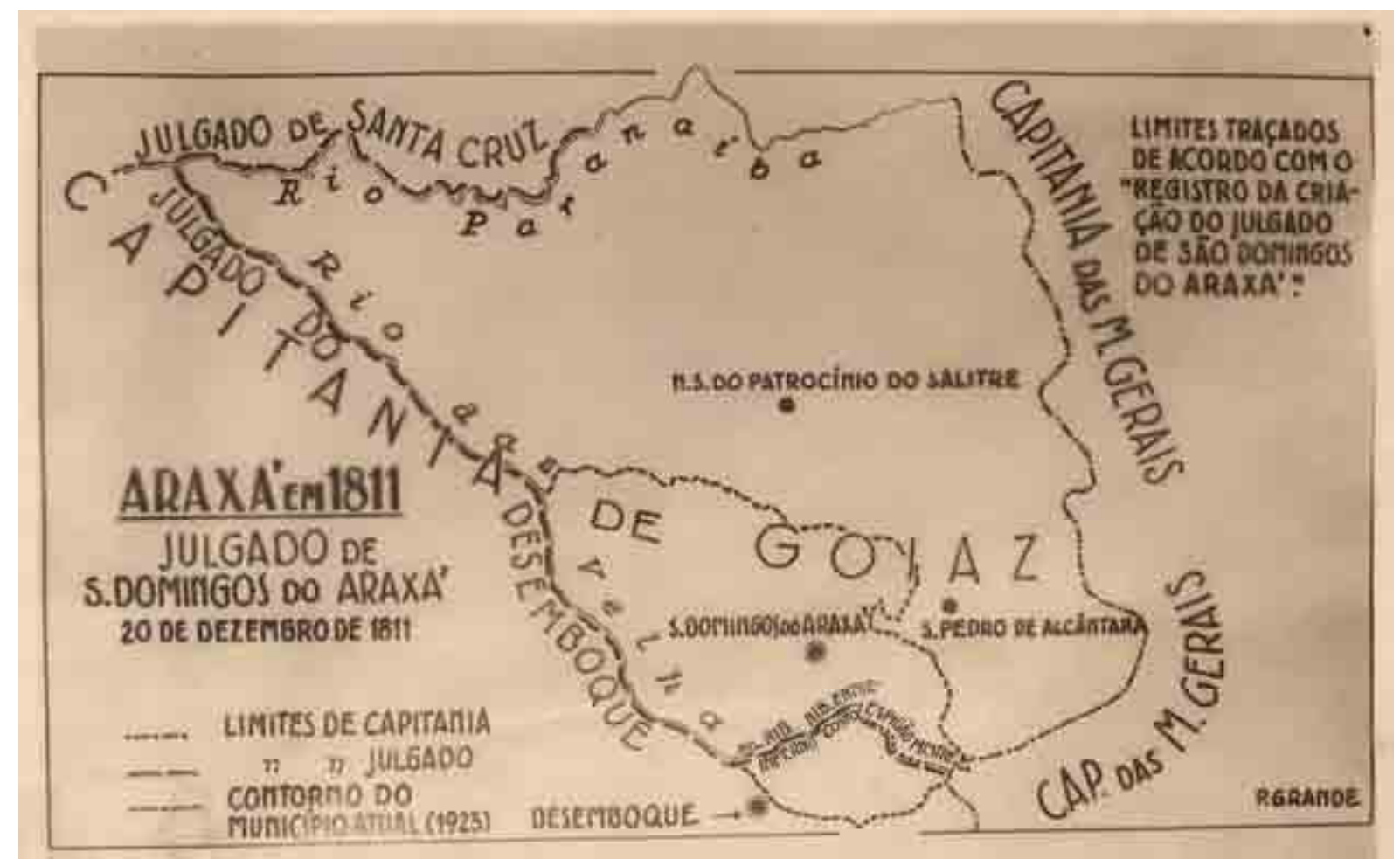

Mapa do Julgado de São Domingos de Araxá (1811 - Fundação Calmon Barreto) 


\section{Anexo 11}

Transcrição da folha 4 (quatro) da cópia do testamento da finada Dona Anna Jacintha de São José

1 parda, da qual lhe faço doa-

2 ção; ou alias a quantia de

3 um conto de reis em dinheiro,

4 qual mais preferir a dita

5 minha neta. $=$ Declaro, que

6 os meos escravos Martinho, Del-

7 fina (casados) continuarão a ser-

8 vir como escravos, aquelle por

9 seis annos, e esta por quatro, a com-

10 tar-se de meo fallesimento,

11 findos os quaes o meo testamentei-

12 ro lhes passará carta de líber-

13 dade. Gosará d'estes serviços

14 a mesma herdeira de minha

15 terça. Nomeio e péço que

16 sejão meos testamenteiros; em

17 primeiro lugar meo genro $\mathrm{Cle}$ -

18 mentino Martins Borges;

19 em segundo lugar meo neto

20 Doutor Francisco Francisco [sic]

21 Ribeiro da Silva, e em terceiro

22 lugar meo Irmão Francisco

23 Antonio Rodrigues; a cada um

24 dos quàes habilito para si $\mathrm{e}$

25 insolidum [?] ad'ministrar os bens

26 respectivos; e ao que aceitar

27 este incargo, deixo de premio

28 cem mil reis; e o tempo de um

29 anno para prestação de com-

30 tas em juiso. Instituo por

31 herdeira do remaneSsente de mi-

32 nha terça a referida minha

33 filha Dona Joana de Deos

(Transcrição feita por Juliana Accioly Amaro Vieira) 


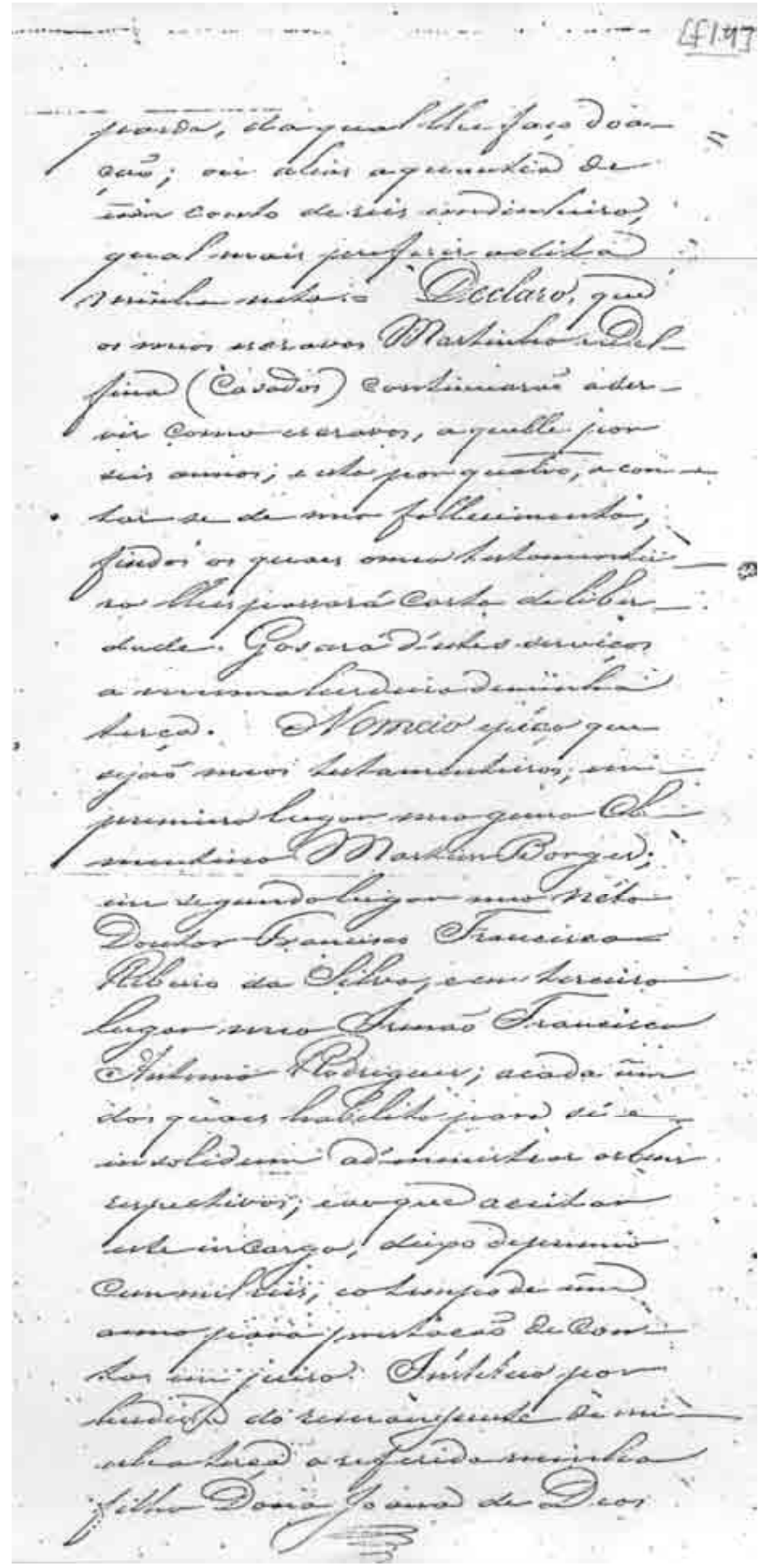




\section{Anexo 12}

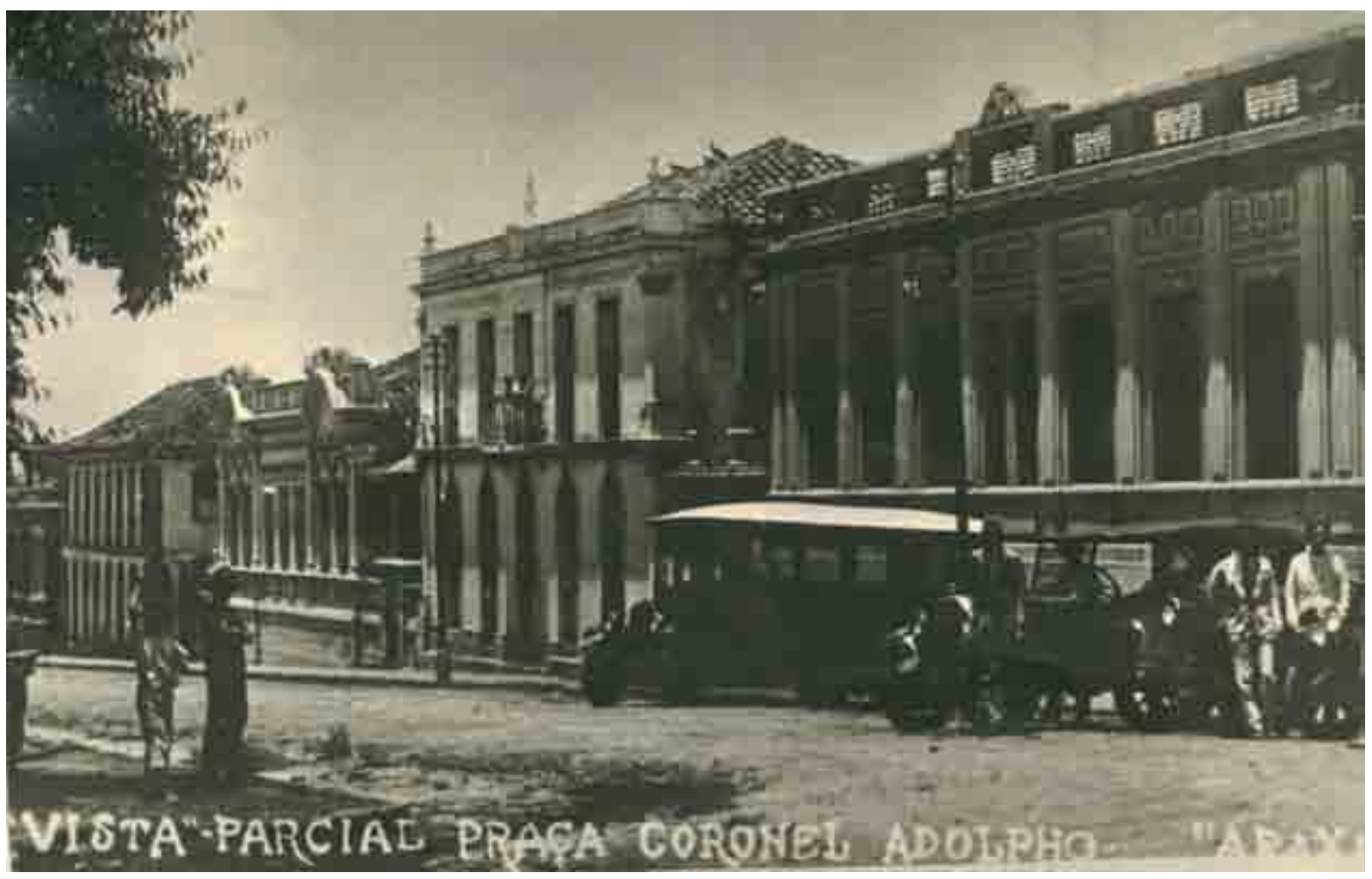

Casa de Dona Beija em São Domingos de Araxá - sobrado branco no centro da foto. Museu Histórico de Araxá Dona Beija - primeiro sobrado à esquerda (Década de 1930 - Fundação Calmon Barreto) 
Anexo 13

ductor:

Valyamos, porem, an nosso assumpto.

Dado o nosso pé de prosperidade ura já muito justo que os araxaenses de entāo, de simples julgido que on A raxá cra, pretendessem exalcal-o a villa com uma camara sua,pma administracto sni, privativamente sua,...

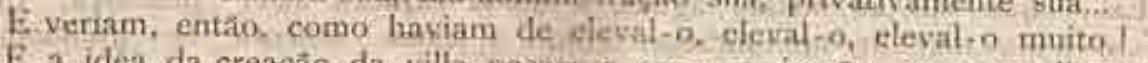

E a idea da creaçäo da villa passan a scr a aspiracato sumema d'aquello povo simples, generusae bom:

\section{A VICTHM DE 1816}

No emtanto lavia em Araxí, aíansdas pela belleza estonteadora dée seus rostinhos de anjo, tres uniheres, tres finrisontaes, que traziam os ingeruos araxaenses de antanho in ima verctuleira polvorosa, cada qual mais ints ressado em chegar á posse exclusiva las pobres deuzas decahidas.

E foram estas tres despracadaa vendendo ac peso don ouro a sua bel. lezat e as suas caricias, que construmatt os tres sobrados, es primeiros que o Arrixá possuio, sque ainda hoje sibo ex orneipal ornamento da ala direi ta-tomado do frontispicio cti egreja - to nosso "Largo da Matriz"

Dentre as tres sereias uma- in main formosa, a mais seductoro-nigo nos interessa canliecer.

Timha ella um nome ile guerra 6 घr a sin. Beifia.

Contrecemot a, ha, 14 anros, helie pura como um casto raio de plen. lumio, quando ella cahia viotima de um menstro horripilante-ro ouyidor geral..

Era clla, a pobre for fanada, agora chácurdada ma lama putrida dos al cauces.

Mais bella do que muncis, vivis cerouda de uma legiấo de adimadores as cuja custa se dava aos matiores excessos da lnxo Näo tendo medida em seus gastos desorderudo, cum sua altis sima critacăo, depenava litteralmente os ricacos da terra presos á belleza inezualavel de sens cabellos neyros. maito bastos, annelidos.

Como todas as cocottes, n'um completo esgotamenito de sentimentos e de sensacoes, nito amava; nâo sentia, mas gostava de ver sentir, de ser ama da,forcando os delirios, os parosismos sentimentaes dos outros, a cuja pai

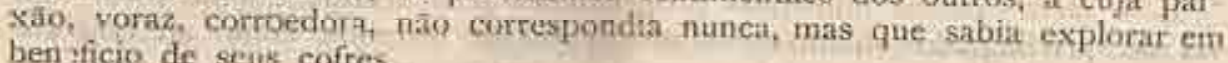
ben ficio de seus cofres.

Assim, ella que fôra um anjo torantiticest um demonio, uma cocotte como qualquer sutra, vulgar e má.

E. dizem que muitos lares, outrioth, opulentos e felizes, the deveram de: pois a pobrrza e a desharmonia quir nelles para sempre se implantaram.

Trecho da matéria "A victima de 1816. Subsídios para a história de Araxá e duas palavras sobre o Triângulo Mineiro”. Folhetim publicado de março a maio de 1815. Correio de Araxá. 


\section{Anexo 14}

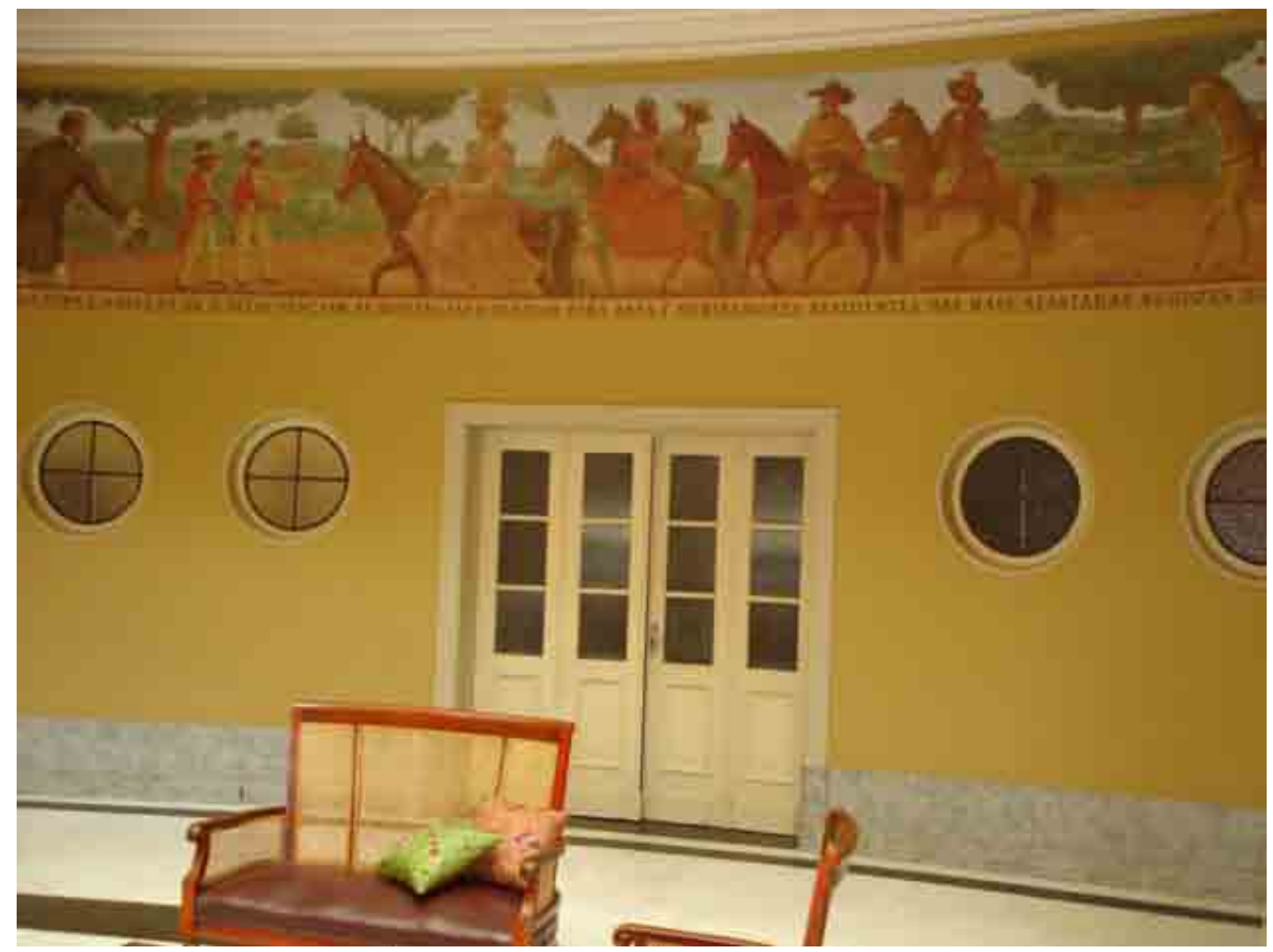

Mural feito por Joaquim Rocha Ferreira, situado nas termas do Grande Hotel do Barreiro - Araxá. (Maio de 2007 - Fundação Calmon Barreto) 


\section{Anexo 15}

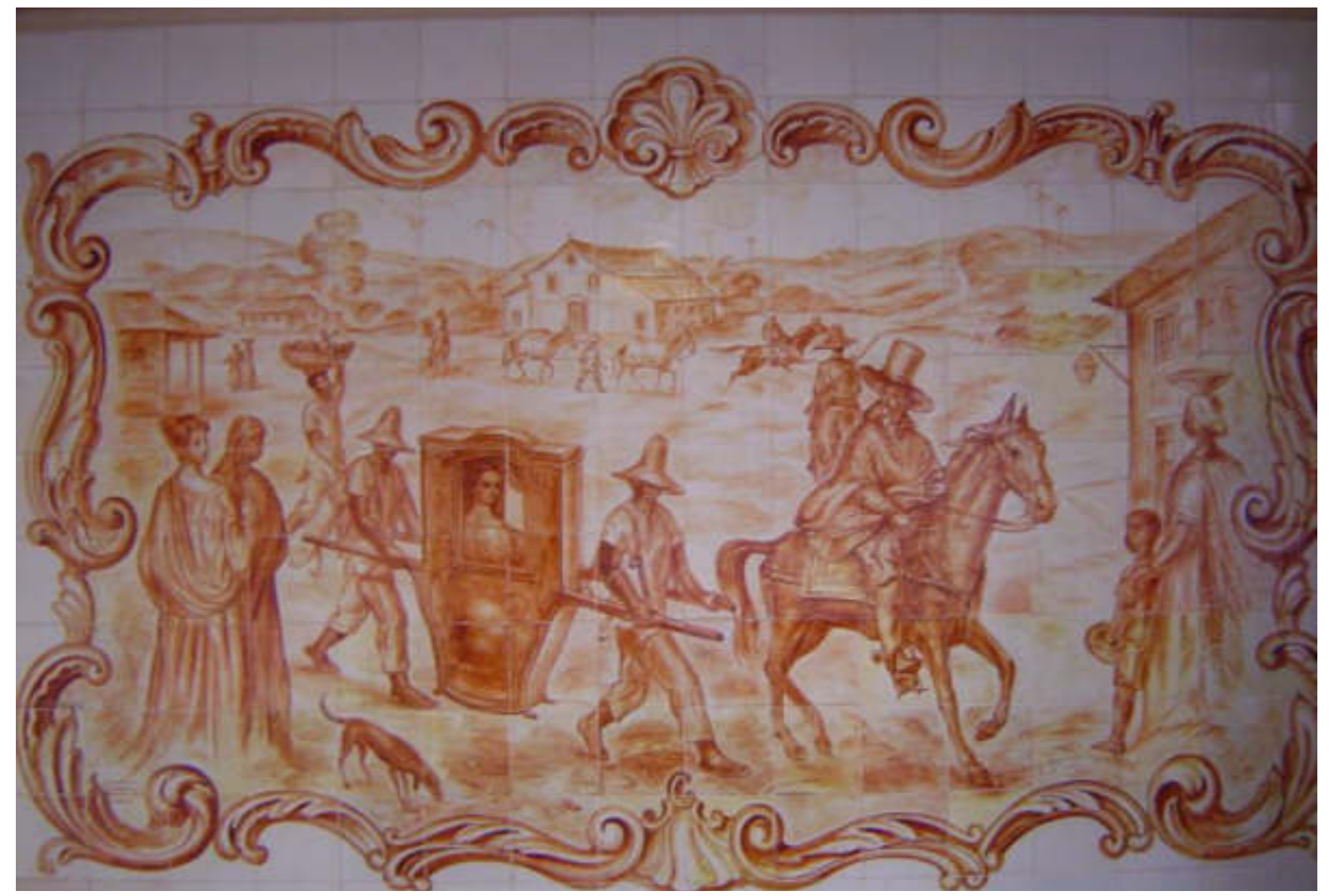

Mural de azulejos feito por Joaquim Rocha Ferreira, situado num dos corredores do Grande Hotel do Barreiro - Araxá (Maio de 2007 - Carlos Silva Júnior) 


\section{Anexo 16}

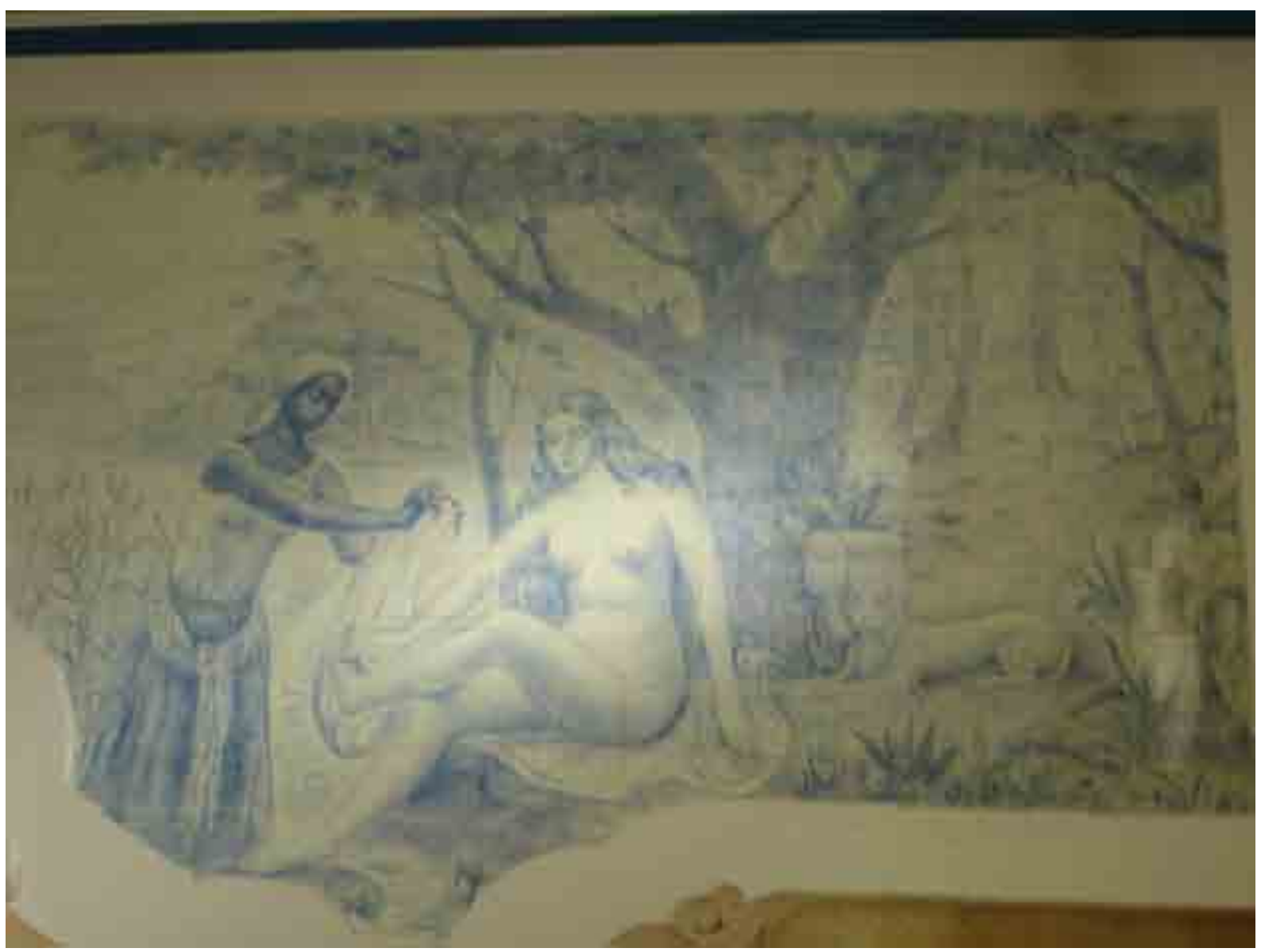

Mural feito por Joaquim Rocha Ferreira,situado na Fonte Dona Beija do Grande Hotel do Barreiro - Araxá (Maio de 2007 - Fundação Calmon Barreto) 


\section{Anexo 17}

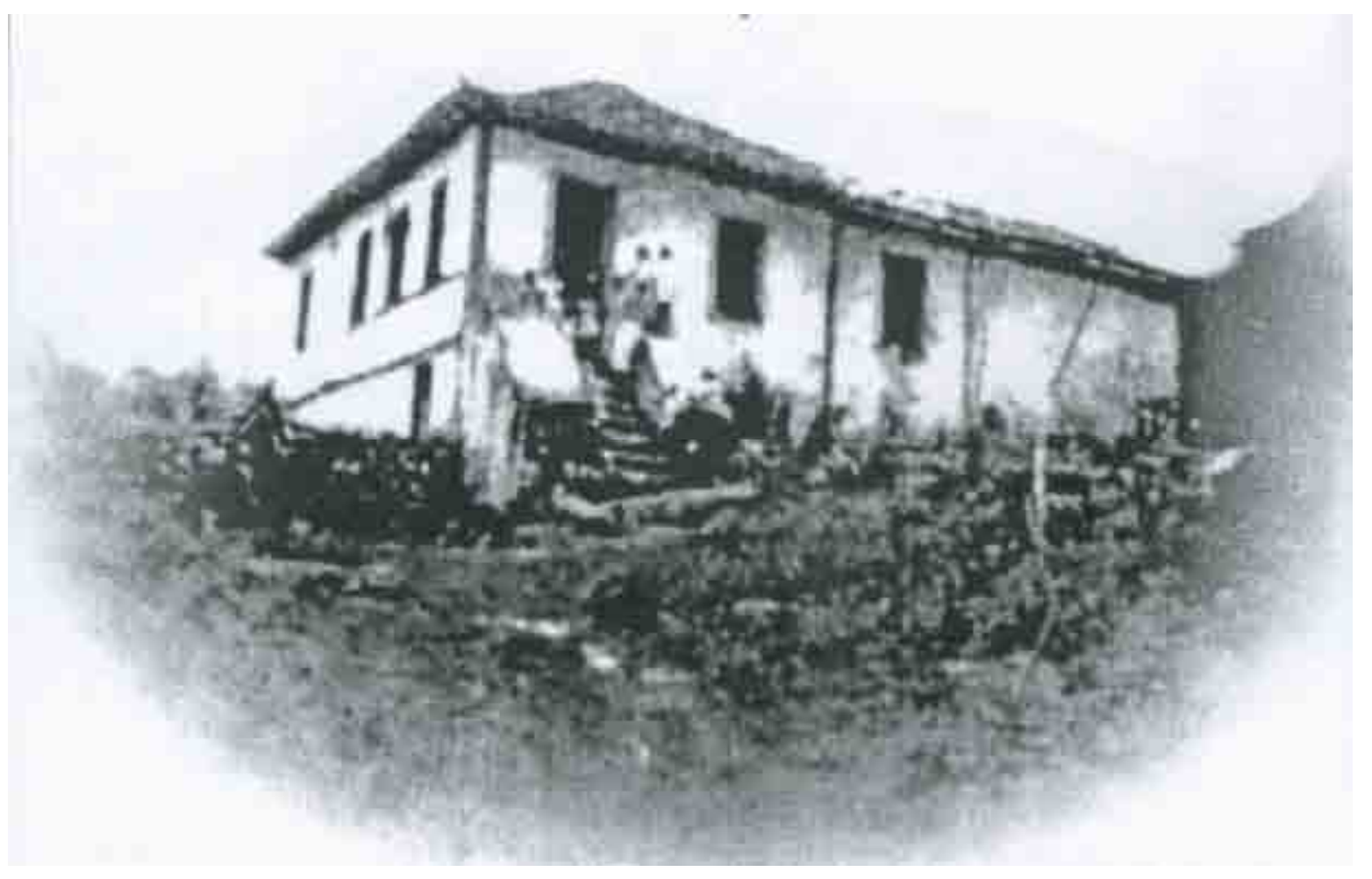

Casa de Dona Beija, situada na Bagagem (Barros, 2003) 


\section{Anexo 18}

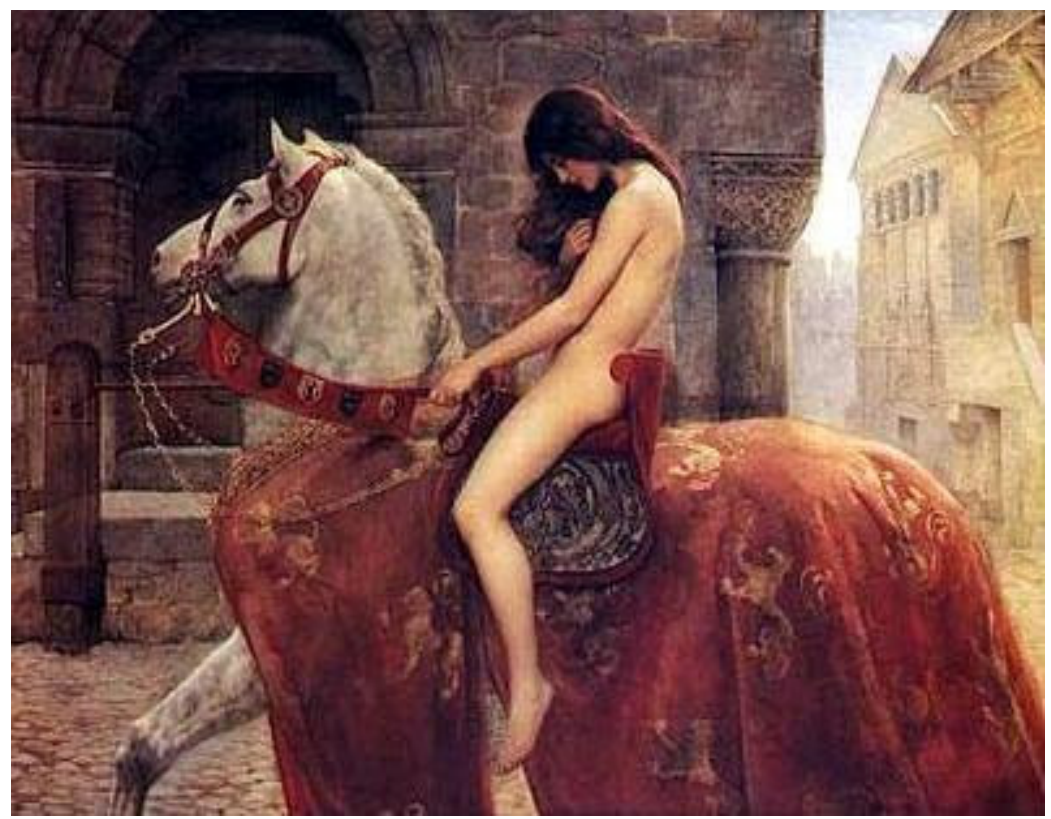

Lady Godiva de John Collier (1897)

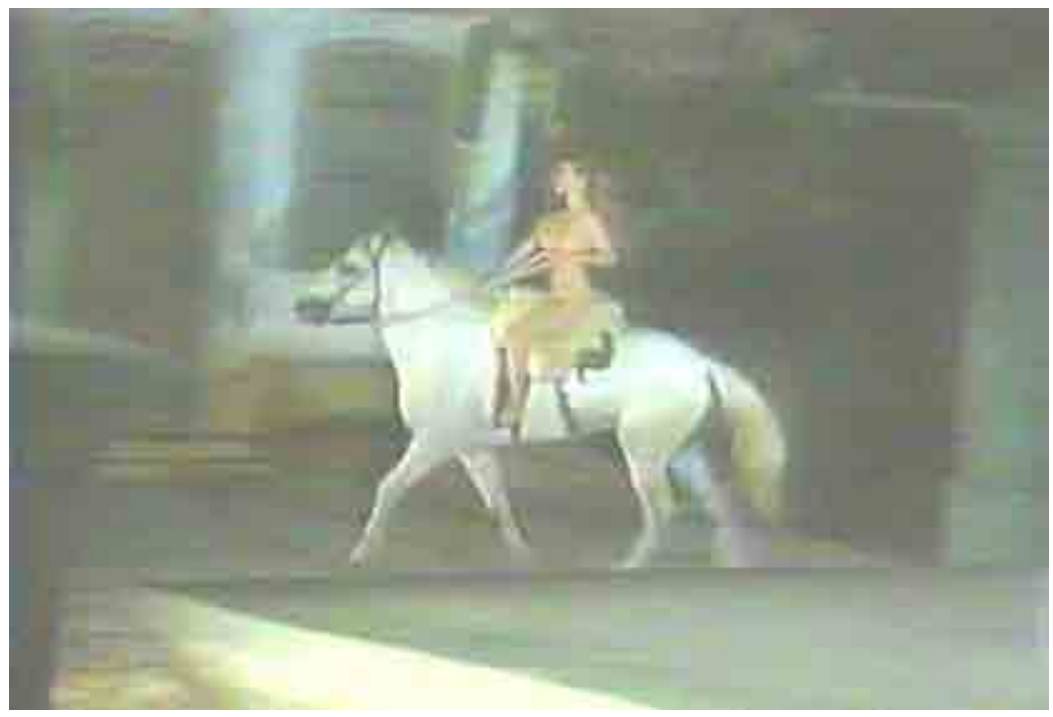

Dona Beija - Maitê Proença (1986) 